\title{
A Night at the
}

\section{(Imaginary) Opera:}

\author{
The visual dimension in Hector
}

Berlioz's Lélio, Roméo et Juliette and

\section{La damnation de Faust}

By

Frances Claire Moore

\author{
A thesis \\ Submitted to the New Zealand School of Music \\ in fulfillment of the requirements for the degree of \\ Master of Music \\ In Musicology
}

New Zealand School of Music 


\section{Abstract}

In keeping with the spirit of Romanticism, Hector Berlioz has always been something of a rogue figure. Works like Lélio, Roméo et Juliette and La damnation de Faust, which Daniel Albright refers to as 'semi-operas', occupy an uncomfortable place within the concert hall. The intersections between song, symphony, opera and the spoken word that form these works immediately pose questions concerning musical unity, narrative interpretation, issues of genre, and performance style. While the musical and literary aspects of the three compositions have been the subject of scholarly attention, this study turns its gaze onto the various visual dimensions that are present within Lélio, Roméo et Juliette and La damnation de Faust. By emphasising the presence of spectacle in Berlioz's compositions, questions soon arise concerning the implications of these visual elements for performance. Berlioz's relatively early work, Lélio, illustrates the extent to which the composer is already concerned with how the visual suppression of performing bodies can create and change narrative meanings. Roméo et Juliette raises the curtains that hide Lélio's musical forces. Rather than simply distilling Shakespeare's drama into music, Berlioz relies instead on a visual memory of Romeo and Juliet to replace the absence of physical characters within his 'symphonie dramatique', thus creating an aural rendition of a past theatrical event. Through an exploration of the spectacle within Lélio and Roméo et Juliette, we see how Berlioz has constructed a visually detailed imaginary theatre that resides within the score. An understanding of this imaginary theatre is integral in the subsequent analysis of Berlioz's controversial and wonderfully diabolical La damnation de Faust. This work is performed as often in the opera house as it is in the concert hall. However, an in-depth analysis of the 
libretto and score reveals curious and occasionally contradictory visual implications. The impact that these contradictions have on the visual dimension in the performance of La damnation de Faust will be explored through a reading of two ground-breaking productions: Raoul Gunsbourg's La damnation de Faust from 1893 - the first production to treat Berlioz's score as an opera; and Robert Lepage's mixed-media production of La damnation. The work of these two directors serves to highlight, perhaps inadvertently, the problematic effects of Berlioz's imaginary theatre on the necessarily more concrete realisations of $L a$ damnation when confined within the opera house. However, the cinematic approach of Lepage suggests another avenue of performance that has the potential to reveal new dimensions of Berlioz's unique dramatic-symphonic works. Ultimately, it may be that the supreme technicolour nature of Berlioz's music always functions to transport us beyond our own mundane experiences and forever challenges us to seek something beyond the limits of the possible, however much those limits might change. 


\section{Acknowledgements}

Many incredibly generous people have impacted the writing of this thesis. My first thank-you must go to my supervisor Dr Inge van Rij. Her passion for Hector Berlioz as well as her extraordinary generosity, patience and care continuously inspires me to aim ever beyond what I think is possible. Her insightful comments and suggestions have been an invaluable guide. I feel lucky and privileged to have worked with her for these past few years.

I would like to express my gratitude to Dr Greer Garden for assisting me with my research in Paris and to Dacia Herbulock for her expertise with the French language. I would also like to thank Geoffrey Coker and the Whetu Kairangi Masonic Trust who helped to support my travels overseas. I am also grateful to Victoria University for providing me with a Victoria Masters Scholarship, without which I would not have been able to undertake this course of study.

Many thanks must go to the staff of the New Zealand School of Music, whose support and engagement with my studies has been at times thought-provoking, challenging and always encouraging.

Writing this thesis would have been nigh impossible without the love and support of my friends and family. I would like to thank my friends for at least attempting to introduce a little perspective into what can be the fraught process of research! I am particularly grateful to Jessie Prebble and Barbie Patterson for their unlimited support - the coffee, cake and wine were always appreciated.

I would not have been able to write this thesis without the practical and emotional support of three incredibly special people in my life - my partner Justin Gregory and my parents Colleen and Charlie Moore. Thank you for putting up with me and undertaking this adventure alongside me. 


\section{Contents}

Abstract $\quad$ ii

Acknowledgements iv

List of Illustrations vi

Introduction 1

Part One: Early Semi Operas

1. Lélio 21

2. Roméo et Juliette 54

Part Two: From Semi-Opera to Opera: Staging Faust

3. Contexts of La damnation de Faust 102

4. Raoul Gunsbourg and La damnation de Faust 157

5. Robert Lepage and La damnation de Faust 185

$\begin{array}{ll}\text { Conclusion } & 214\end{array}$

$\begin{array}{ll}\text { Bibliography } & 217\end{array}$ 


\section{List of Illustrations}

Figure 1: Maurice Sand's picture of the character Lélio from

Masques et bouffons (1860). P. 35.

Figure 2: 'L'homme orchestre', lithograph by Benjamin

Roubaud. P. 63.

Figure 3: John Martin's The Deluge 1834. P. 110.

Figure 4. Gunsbourg's diagram of Faust's study from

Gunsbourg's Livret de mise-en-scène. P. 170.

Figure 5. Diagram detailing the props on Faust's desk from

Gunsbourg's Livret de mise-en-scène. P 174.

Figure 6. Diagram of rain machine from Gunsbourg's Livret de mise-en-scène. P. 177.

Figure 7. Diagram of panorama from Gunsbourg's Livret de de mise-en-scène. P. 178.

Subsequent photos taken from L'avant-scène opéra: Hector Berlioz.

La damnation de Faust, Vol. 22.

Figure 8. P. 186.

Figure 9. P. 186.

Figure 10. P. 187. 


\section{Introduction}

Berlioz's compositions no doubt require us to find a style of presentation unconnected with any of those that we still accept today, since the latter exists for works conceived in terms of certain predetermined categories. This is an essential condition, I believe, if these works are to find their rightful place, if they are no longer to produce, as they often do now, the impression of an incomplete phenomenon, an erratic creation. (Pierre Boulez, 'Berlioz and the Realm of the Imagination) ${ }^{1}$

Berlioz has often been described as an original mind, a composer who flaunted rules and regulations and was a determined pioneer. As Pierre Boulez points out above, it is this reputation that often stands in the way of our coming to terms with Berlioz's compositional style and how we should perform his music. However, through an analysis of three dramatic scores I will reveal how there is, after all, a method to his (supposed) madness. ${ }^{2}$ The symphonic dramatic works Lélio, Roméo et Juliette, and La damnation de Faust all have a reputation for being slightly out of the ordinary. All three works are almost unique in their genre and varied in their formal structure, style and instrumentation. All three works also pose complex questions in regards to their performance. While many scholars have commented on the music and text within these compositions, very little analysis has been done on their

\footnotetext{
${ }^{1}$ Pierre Boulez, 'Berlioz and the Realm of the Imaginary', Daedalus, 115/4 (1986) 'The Future of Opera' 183-184.

${ }^{2}$ Indeed, Mendelssohn once remarked about Berlioz that 'with all his efforts to go stark mad he never once succeeds'. Charles Rosen, The Romantic Generation (Cambridge, Massachusetts; Harvard University Press, 1995), p. 542.
} 
intended visualisation in performance, or, more specifically, Berlioz's interest in the suppression of visual spectacle in these highly dramatic compositions. A close examination of Lélio, a relatively early work of Berlioz's, (it was first performed in 1832), not only highlights the composer's interaction with the literary and theatrical ideas of his time, but also exposes a concern with the visual relationship between performing musical bodies, the narrator and the audience's imagination. Seven years later Roméo et Juliette was first performed. This work takes another step forward in the exploration of visuality, and replaces the spoken monologues of Lélio with sung text. While defined as a 'symphonie dramatique', Roméo et Juliette is highly suggestive of staged theatre, constantly alluding to a specific production of Shakespeare's play. The relationship between the music and questions of visual representation (both those implied within and those outside of the music) will come to be a central issue in our understanding of the controversial $L a$ damnation de Faust, Berlioz’s 'légende dramatique’ from 1846. Though intended as a concert work, La damnation de Faust, since 1893 and continuing throughout the twentieth and into the twenty-first century, has just as often been staged as an opera. Thus through these three works we can see how Berlioz was continuously exploring questions of visual representation in musical performance. As we will discover, there seems to be a teleological journey that takes place across these diverse works as Berlioz shifts from hiding away his orchestra in order to more dramatically tell a story, to giving his orchestra a voice and eventually letting it carry us away to witness the heights of heaven, the depths of hell and everything that happens in between. 
It is only through exploring the way in which Berlioz has created a very specific visual world within Lélio, Roméo et Juliette, and La damnation de Faust that we can find what Boulez terms that evasive, appropriate 'style of representation'. Boulez states that 'the discovery of this point of encounter and fusion between imaginary concert and imaginary theatre remains naturally very problematic, especially since the values represented by Berlioz's works are frozen by history, whether or not one tries to deny this fact. ${ }^{33}$ In our own times will Berlioz's works be better understood through the use of cinema in their realisation? What is the nature of the impact that this inevitable cinematic appropriation will have on Berlioz's own nineteenthcentury values, hidden in the many layers of meanings within these works?

Berlioz's Semi-Operas: Roméo et Juliette and La damnation de Faust provides a useful point of departure for this study. ${ }^{4}$ Daniel Albright's book is unusual within Berlioz scholarship, in that it turns its gaze exclusively onto two of Berlioz's compositions that stand outside of more conventional genre and form classifications. Albright draws an analogy between Hector Berlioz and the works of Henry Purcell to apply the label 'semiopera' to Berlioz's Roméo et Juliette and La damnation de Faust; Albright compares the manner in which Berlioz wrestles drama into concert music to the way in which Purcell adapted his music to suit theatrical drama. ${ }^{5}$ As the title of his book suggests,

\footnotetext{
${ }^{3}$ Boulez, 'Berlioz and the Realm of the Imaginary', 184.

${ }^{4}$ Daniel Albright, Berlioz's Semi-Operas: Roméo et Juliette and La damnation de Faust (Suffolk: University of Rochester Press, 2001).

5 Ibid., p. xi.
} 
Albright approaches these works from an operatic ideal. In these compositions we can see how Berlioz, exasperated by the opera bureaucracy in Paris, 'devised operas for the private spaces of the imagination, spaces where a cello could sing the role of Roméo if desired, spaces in which elaborate operatic scenes could be erected in an instant, then switched off at pleasure. ${ }^{6}$ Like Albright, I too have decided to concentrate on these two unique works while also including a survey of Lélio, in part because Albright defines this youthful work as an 'apprentice semi-opera', but also because Lélio is essential in illustrating the way in which Berlioz, from an early stage in his career, was interested in how non-operatic music could contain drama and how the sight of an orchestra could create narrative meanings. ${ }^{7}$ Considering Albright's background as a Professor of Literature at Harvard University, it is unsurprising that his work on Berlioz's 'semi-operas' puts as much emphasis on the history and development of the texts from which Berlioz based his compositions, as on Berlioz's own musical interpretation of these texts within his 'semi-operas'. Albright is careful to consider the changes to the text that Berlioz made in developing Shakespeare and Goethe for the concert hall, and what these choices and their musical realisations may expose about Berlioz as a composer. However, Albright, like many other scholars, does not explore the manner in which Berlioz references the defining visual spectacle of the plays of Shakespeare and Goethe within the text, music, structure and form of his concert works. An acknowledgement of Berlioz's translation of a visual spectacle into the aural spheres of Lélio, Roméo et Juliette and La damnation de Faust may illuminate and reveal new aspects of

\footnotetext{
${ }^{6}$ Ibid., p. xi.

${ }^{7}$ Ibid., p. 131.
} 
Berlioz's musical programmes. It is the encoding of visual programmes within Lélio, Roméo et Juliette and La damnation de Faust that I hope to uncover in this study. Perhaps a greater understanding of these visual allusions may influence the way in which we chose to perform his dramatic compositions.

Thus, our programme begins with Lélio, a dramatic work that alternates spoken monologues with musical movements. Its compositional genesis is important in illustrating the extent to which Berlioz incorporated the most progressive literary and theatrical philosophies into his musical compositions. Details such as title and subtitle are made more comprehensible through an understanding of their literary origins and contexts. It is also by examining this often-dismissed work that we will see how Berlioz, inspired by literary precedents, began to explore the idea of creating concerts within concerts, and how the specific visual experience of Lélio is just as significant as other programmatic elements in understanding the larger narrative trajectory of this 'patchwork' composition.

Our attention will then turn towards Roméo et Juliette. Again, an understanding of this work's compositional gestation will prove relevant in exposing Berlioz's growing concerns with the limits of musical-theatrical performance in much contemporary grand opera. The musical-analytical approaches of Stephen Rodgers and Julian Rushton will help to expose the manner in which Berlioz's music is highly suggestive of specific visual 
environments as well as descriptive of physical actions. ${ }^{8}$ The work of Albright and John R. Elliot, Jr. will remind us of the particular version of Shakespeare's play that Berlioz first set eyes on. ${ }^{9}$ Through these accounts of the Abbott company's performances of Romeo and Juliet that so moved Berlioz, we will discover how the composer chose not to re-create the drama of Shakespeare's play but rather compose a musical experience that captured his own experience of watching this tragic story unfold. Understanding this relationship between score and theatrical event will reveal Berlioz to have composed a kind of soundtrack to a visual memory of a specific performance.

The second half of our programme is dedicated to Berlioz's $L a$ damnation de Faust. The approaches to visual narration already present in Lélio and Roméo et Juliette reach their ultimate fulfilment and threaten to burst the seams of La damnation de Faust. Coupled with the musical-analytical approaches of Albright and Rushton, the work of Carolyn Abbate is used as a model in this section to expose hidden voices and larger diabolical narrative meanings. ${ }^{10}$ Her methods of differentiating between noumenal and phenomenal music to explore how an audience experiences musical performance, in all its temporal glory, is particularly relevant in music that is already visually problematic in performance. These terms are applied here to

\footnotetext{
8 Stephen Rodgers, Form, Program, and Metaphor in the Music of Berlioz. (Cambridge: Cambridge University Press, 2009); Julian Rushton, Berlioz, Roméo et Juliette (Cambridge: Cambridge University Press, 1994).

9 Albright, Berlioz's Semi-Operas: Roméo et Juliette and La damnation de Faust; John R. Elliot, Jr., 'The Shakespeare Berlioz Saw', Music \& Letters, 57/3 (1976), 292-308.

${ }^{10}$ Carolyn Abbate, Unsung Voices: Opera and Musical Narrative in the Nineteenth Century (Princeton, NJ.: Princeton University Press, 1991).
} 
differentiate between music that the characters can hear (phenomenal) and music that the characters cannot hear (noumenal) - a similar construction to diegetic and non-diegetic music as it is understood in film music studies. By applying the linguistic techniques of Abbate and asking ourselves who is 'singing', who is 'listening' and who is 'narrating', we will begin to discover more skeletons hiding in Berlioz's closet. These various skeletons and complexities will prove La damnation de Faust to be more than simply a hybrid symphony with higher aspirations towards Opera. By placing Berlioz's approaches to visuality at the forefront of this study, rather than as an interesting aside as has previously been the case, we can begin to answer Boulez's call to meaningfully consider how indeed Lélio, Roméo et Juliette and La damnation de Faust should be approached in performance today.

In conclusion, by examining two productions of La damnation de Faust, treated as an opera, I hope to expose not only how the latent visual aspects of Berlioz's score can become problematic in visual performance, but also how modern visualisation can perhaps replace the historically 'frozen' ideals that were pertinent to Berlioz's own context as Boulez suggests. The indispensable collection of original nineteenth-century staging documents edited by H. R. Cohen, the mise-en-scène of Raoul Gunsbourg and various published interviews and documents from Robert Lepage are all used to better understand practical nineteenth-century operatic practices, early twentieth-century 
approaches to operatic performance and the most modern developments in symphonic-operatic-cinematic theatre. ${ }^{11}$

However, before we can explore how more modern values may be appropriately placed upon the generically ambiguous compositions Lélio, Roméo et Juliette and La damnation de Faust, excavating the historical values that inspired these compositions is also important. Some of the best insights into how we can understand these nineteenth-century contexts of course come from the composer himself. As Berlioz once wrote:

Instrumental music used only to be intended to please the ear or engage the intellect [...] but in Beethoven and Weber, poetic thought is ubiquitous and cannot be overlooked [...] This music needs no words to make its expression specific; it develops a language which is generally imprecise, and which as a result has all the greater impact upon listeners endowed with imagination [...] the composer is no longer constrained by the limitations of the voice and produces melodies which are more active and varied, phrases that are more original, even bizarre, without being afraid that they might be unplayable [...] From this stem the astonishing effects, the strangest feelings, the ineffable sensations, which the symphonies, quartets, overtures and sonatas of Weber and Beethoven produce in us, quite unlike those stimulated in the theatre. There we are in the presence of human emotions; here a new world is displayed, and we are raised towards a higher ideal region, sensing that the sublime life dreamed of by poets is becoming real $[\ldots]^{12}$

${ }^{11} \mathrm{H}$. Robert Cohen, The original staging manuscripts for twelve Parisian operatic premieres (Stuyvesant, NY: Pendragon, 1991); Raoul Gunsbourg Berlioz: La damnation de Faust, Mise-en-scène, (Paris: Costallat \& Co., c.1907); August Ventura, 'Dreamcatcher' in Opera News 73/4 (2008); The Metropolitan Opera Playbill (November 2008).

${ }^{12}$ Hector Berlioz, in Le Correspondant, 22 October 1830, quoted and translated in Julian Rushton, 'Music and the poetic' in The Cambridge History of 
Berlioz here articulates an attitude towards symphonic music that was shared by many avant-garde composers and artists of the nineteenth century. According to Carl Dahlhaus's famous dialectic, the early nineteenth century was dominated by the 'twin styles' as exemplified in the operas of Rossini and the symphonies of Beethoven. ${ }^{13}$ Certainly it was the influence of Beethoven and the religious fervour his name and symphonies inspired in all those who understood them that was thought to permeate all things noble and high throughout the second half of the long nineteenth century. A belief was instilled in Berlioz almost from his arrival in Paris in 1821 that instrumental music could indeed contain tragedy, love, death and the whole gamut in between, in a nature that expressed that which couldn't be expressed through language. It was this revelation that would lead to the composition of dramatic symphonic works that would expand the boundaries of the symphony itself and cement Berlioz's reputation as a significant innovator in nineteenth-century music. Berlioz did not compose symphonic works for orchestra alone; he composed works of a hybrid nature mixing together songs, arias, choruses, monologues and programmes alongside instrumental pieces. These genres and forms would then be bound together in single works and be variously labelled 'Mélologue', 'Symphonie dramatique', 'Légende dramatique'. It should not be surprising that Berlioz wished to combine the 'presence of human emotions' as expressed through voice and text within the 'higher ideal region' that music alone can inspire.

Nineteenth-Century Music ed. Jim Samson (Cambridge: Cambridge University Press, 2001), p. 152. (Italics mine.)

${ }^{13}$ Carl Dahlhaus, Nineteenth-Century Music, trans. J. Bradford Robinson (Berkeley: University of California Press, c1989), p. 8. 
In examining Berlioz's statement above, one must ask: if Berlioz was so struck by the ability of the works of Beethoven and Weber to convey the imprecise, which has a greater impact 'upon listeners endowed with imagination', why did Berlioz himself often frame his compositions with programmes describing specific scenes, emotions, actions and consequences? Indeed one would be hard pressed to find any commentary on Berlioz that does not mention the fact Berlioz was a pioneer, if not the pioneer, of programme music.

One of the greater ironies in the performance of Berlioz's symphonic works lies in the fact that his music is not only programmatic but also contains 'absolute music' values as well. It has been a common myth that the term 'absolute', as it applies to music, was a significant aspect of any dialogue surrounding music in the nineteenth-century. The works of Carl Dahlhaus and Roger Scruton propelled myths that the term 'absolute music' was first coined by Eduard Hanslick and championed by E.T. A. Hoffmann, J. L. Tieck, and J. G. Herder. ${ }^{14}$ However, McClary, Chua, Hoeckner and Pederson have uncovered the history and development of the term and questioned many of our long-standing assumptions of how this term was used and understood in nineteenth-century contexts and how it has been used and misunderstood in more modern contexts. ${ }^{15}$

\footnotetext{
${ }^{14}$ See Roger Scruton, 'Absolute music' in Grove Music Online. Oxford Music Online,

http://www.oxfordmusiconline.com/subscriber/article/grove/music/00069 (accessed July 26, 2009) and Dahlhaus, The Idea of Absolute Music, trans. Roger Lustig (Chicago: University of Chicago Press, c1989).

15 Susan McClary, 'Narrative agendas in "Absolute Music: Identity and Difference in Brahm's Third Symphony', in Ruth Solie (ed.), Musicology and Difference: Gender and Sexuality in Music Scholarship (Berkeley: University of California Press, 1993); Daniel K. L. Chua, Absolute Music and the Construction of Meaning (Cambridge: Cambridge University Press, 1999); Berthold
} 
Recent research suggests that it was in fact Wagner who first used the term 'absolute' and the use of this term by authors such as Hoffmann and Herder was in reference to important philosophical ideas of the nineteenth century but certainly not music. It is important to now recognise that any dialectic between programmatic music and absolute music has been a framework created by late nineteenth-century and early twentieth-century critics to champion certain musical ideals and personalities. Terms such as 'programme' and 'absolute' music can only be defined by what they are not and the relationship between autonomous and narrative musical structures is more complex than any binary opposition. The heightened emotions Thomas Moore, Shakespeare and Goethe stirred within Berlioz were an integral source of inspiration; Berlioz's ideal was to imitate this same sense of absolute awe beyond language and meaning within his own narrative musical works.

It is also important to recognise the primary position of opera within French cultural life during Berlioz's lifetime. Paris was the indisputable musical capital of Europe throughout the nineteenth century, attracting composers from Donizetti and Rossini to Chopin and Liszt. Ever since he saw a production of Auber's La Muette de Portici when he was just twenty years old, it had been Wagner's determination to compose a grand opera spectacularly appropriate to triumph at l'Opéra, (though Wagner's flight to Paris and his attempted grand opera offering Rien $2 i$ was a fiasco. $\left.{ }^{16}\right)$ Within Paris there was an insatiable

Hoeckner, Programming the Absolute: Nineteenth-Century German Music and the Hermeneutics of the Moment (Princeton and Oxford: Princeton University Press, 2002); Sanna Pederson, 'Defining the Term 'Absolute Music' Historically', Music \& Letters, 90/2 (2009) pp. 240 - 262.

${ }^{16}$ For a more thorough exploration of Grand Opera's influence on Wagner see Thomas Grey, 'Richard Wagner and the legacy of French grand opera', in 
appetite for opera and opera alone. Indeed, as Jeffrey Langford explains, so 'great was its passion for opera that interest in other genres dwindled; the theatre was the primary source of public music. This pre-eminence did not occur suddenly but was well prepared by centuries of French preference for vocal over instrumental music. ${ }^{, 17}$ To be considered a success in Paris, it was necessary to be a successful composer of opera. Berlioz's decision to abandon his medical studies and take up composition was undoubtedly solidified at the Opéra and it was during his decades of attendance at this majestic house of music, magic and spectacle that he witnessed the rise of grand opera. In a letter to his sister Nanci, from 13 December 1821, Berlioz described how he had found two pleasures in Paris - the vivid and evocative history lectures of Charles de Lacretelle and the Opéra. As Berlioz writes:

The Opéra, at the moment, is something of a different order and I don't feel I can possibly describe it to you. Short of actually fainting, I couldn't have felt stronger emotions than I did seeing Gluck's masterpiece Iphigénie en Tauride. Imagine first of all an orchestra of eighty players whose ensemble is so good, you'd say they were a single instrument. The opera begins: in the distance you see a vast plain (the illusion is absolute) and farther off still the sea; the orchestra warns of a storm and you see black clouds slowly descending and covering the whole plain; the theatre is lit only by flashes of lightening piercing the clouds, so true to life you would have to see to believe. [...] And the orchestra! All that was in the orchestra. If you could only have heard how it describes every situation, especially when Orestes appears to be calm; the violins have a very quiet held note, a symbol of tranquillity; but underneath you can

The Cambridge Companion to Grand Opera, ed. David Charlton (Cambridge: Cambridge University Press, 2003), pp. 321-343.

17 Jeffrey Langford, 'The "Dramatic Symphonies" of Berlioz as an Outgrowth of the French Operatic Tradition', The Musical Quarterly, 69/1 (1983), 85. 
hear the basses murmuring like the remorse which, despite his apparent calm, still lurks deep in the heart of the patricide. ${ }^{18}$

This letter not only articulates the centrality of spectacle in the grand opera Berlioz witnessed, but also Berlioz's attraction towards the orchestra and its capabilities to evoke drama. Opera had taken on many guises throughout its history and was going through another metamorphoses during the later years of the decade of the 1820s in Paris. What emerged was the grand opera of Meyerbeer, Rossini and Auber. This grand opera was a 'cultural document of the July Monarchy', emerging from an industrialised Paris as well as being significantly influenced by the 'noisy' revolutionary writings of Hugo and Dumas. ${ }^{19}$ The salient difference between this new genre of grand opera and older models was the centrality of spectacle and the primary position of large chorus and ensemble scenes over individual arias and recitative. This is a natural development in a city shaped and reshaped by mass revolution; we can understand the primacy of the chorus in grand opera within an historical context where the very same audience members had witnessed, on the streets of Paris, the capacity of the will of the people to effect change. ${ }^{20}$ The subject turned from ancient, classical stories to more romantic, medieval, historic tales, and the pace in which stories were told also changed significantly. As Dahlhaus states, 'The principle of this species of opera was to switch abruptly between mass scenes and touching romances or prayers, between coloratura and outbursts of passion, between

\footnotetext{
${ }^{18}$ Hector Berlioz in a letter to his sister Nanci dated 13 December 1821, in Berlioz, Selected Letters of Hector Berlioz, p. 5.

${ }^{19}$ Dahlhaus, Nineteenth-Century Music, p. 125.

${ }^{20}$ Ibid., p. 125.
} 
instrumental solos and violent orchestral devices. ${ }^{21}$ This was opera that valued shock and moved from stunningly visual tableau to tableau. Visual splendour came to almost surpass the text of the music itself. The opera impresario Louis Véron describes in his memoirs how an army of 'sixty machinistes occupied the stage décor of grand opera'. ${ }^{22}$ Such a mass of stagehands is understandably essential considering that throughout the height of grand opera's popularity, from 1828 to the early 1840s, efforts were made not only to create striking tableaux, but to try and re-create models of the exact places these historic events took place. As Karin Pendle and Stephen Wilkins describe:

Though at times this atmosphere was essentially newcreated, at other times exact models of historical buildings appeared on stage - the cloister in Robert le diable, for example, or the country chateau in Les Huguenots' second act. This attitude toward stage design was intended to result not in spectacle for its own sake, then, but spectacle as an important component of the expressive power of the work. ${ }^{23}$

Indeed the dominance of these tableaux had important implications for the text of the music. As Dahlhaus informs us, Véron felt that ' $[\mathrm{t}]$ he dramatic events [...] Must be comprehensible as visible action without regard for the text, just like the scenario of a ballet. It is not dialogue, which is virtually swallowed up by the music, but the striking, "speechlike" arrangements of the agents - among whom Véron also includes

\footnotetext{
${ }^{21}$ Ibid., p. 125.

22 Ibid., p. 126.

${ }^{23}$ Karin Pendle and Stephen Wilkins, 'Paradise Found: The Salle le Peletier and French Grand Opera' in Opera in Context: Essays on historical staging from the late Renaissance to the time of Puccini, ed. Mark A. Radice (Portland: Amadeus, 1998), p. 172.
} 
the chorus - that constitutes the primary expressive means of a dramatic technique as legitimate in the opera as inconceivable in the theatre. ${ }^{24}$ The primary position of grand opera within French cultural life and the importance of the visual spectacle of opera throughout the nineteenth century should not be underestimated.

It is unsurprising, considering the centrality of opera to the musical world of Paris that Berlioz should have also wished to become an operatic composer. Even before 1826, the year when he finally gave up his medical studies and enrolled as a composition student at the Conservatoire, Berlioz, with relatively little formal musical training, had already embarked on two full-length operas, Les Francs-Juges (1825-1826) and Estelle et Némorin (1823) and had planned an opera, Richard en Palestine, based on a novel by Walter Scott, (though difficulties with the librettist prevented this project from going ahead. $)^{25}$ The complete scores of these early operas are now lost. His Memoirs also express how, in order to become a successful composer of opera, one must go through the time honoured process of winning the Prix de Rome, travelling to Italy - the homeland of Opera - and returning triumphant with the reasonable expectation of being offered libretti and a foot in the door of the massive bureaucracy that was l'Opéra. ${ }^{26}$ Though eventually a Prix de Rome winner, Berlioz's path was to be filled with trials

\footnotetext{
${ }^{24}$ Dahlhaus, Nineteenth-Century Music, p. 126.

${ }^{25}$ Langford, "The "Dramatic Symphonies" of Berlioz as an Outgrowth of the French Operatic Tradition', 87.

${ }^{26}$ A very entertaining account of the importance of the Prix de Rome and the composer's various attempts to win this prestigious prize can be found in chapters 22 through to 29 of Hector Berlioz, The Memoirs of Hector Berlioz, trans. David Cairns (New York: Alfred A. Knopf, 2002).
} 
and tribulations some of which we will touch upon later, yet the great influence of this dramatic genre can be seen to have been incorporated into his non-operatic works in fascinating ways. It is easy to find an apologetic tone throughout much of the writing concerning Berlioz. My exploration of the cross-sections between opera and symphony, theatre and literature, visuality and imagination, hopes instead to illuminate the way in which Berlioz created a form of music drama, not as a substitute for opera, but as something unique and valuable in itself.

That Berlioz was not an opera composer and instead a symphonist was an aspect of his compositional style that was specifically championed in the press. While Berlioz had three operas performed at l'Opéra, not one of these permanently entered the repertoire during his lifetime, and music critics of the time encouraged an understanding of Berlioz as a composer of symphonies. The Revue et gazette musicale de Paris, perhaps ones of the most influential musical periodicals within France throughout the nineteenth century, focused more attention and column space on Berlioz than any other composer, including Beethoven. ${ }^{27}$ Yet this attention was not extended to all of Berlioz's repertoire but rather specifically his dramatic symphonic works. The writers of the Gazette, alongside other music critics, felt they needed to educate future audiences about Berlioz and his symphonies as they felt that these were his most important contributions to the musical world. ${ }^{28}$ As a direct result of this, his operatic works were all but ignored;

${ }^{27}$ Katharine Ellis, Music criticism in nineteenth-century France: La revue et gazette musicale de Paris, 1834-80 (Cambridge: Cambridge University Press, 2007), pp. 220-221.

28 Ibid., p. 230. 
throughout the forty-seven years of this journal's august history, Berlioz's major operatic and vocal works such as Les Troyens, Béatrice et Bénedict and Les Nuits d'eté each only received a single article. ${ }^{29}$ Many critics complained that Berlioz's operas contained too many aspects of instrumental music and as Katharine Ellis states, such 'paradoxes fuelled the irony that the journal's critics viewed Berlioz's operas as driven by their music and his symphonies as driven by their drama. ${ }^{30}$ This prevailing attitude towards Berlioz certainly influenced his subsequent reception. Consequently we return to that old quandary about the chicken or the egg. Was Berlioz unsuccessful as an opera composer because his operas received so little attention from the press and public at large, or did his operas receive so little attention from the press and public at large because he was 'really' a symphonist?

Regardless of the perception of Berlioz's operas, not everybody thought of Berlioz as an admirable composer of symphonies. It was Richard Wagner who declared that he wished to create a 'theatre of the mind', a theatre of the imagination. As Wagner stated, 'having created the invisible orchestra, I now feel like inventing the invisible theatre'. ${ }^{31}$ As Dieter Borchmeyer explains, this comment sprung from Wagner's supreme adoration of Beethoven's symphonies. Wagner claimed that Berlioz's development of the symphony after Beethoven had

\footnotetext{
${ }^{29}$ Ibid., p. 221.

${ }^{30}$ Ibid., p. 230.

${ }^{31}$ Dieter Borchmeyer, Richard Wagner: Theory and Theatre, trans. Steward Spencer (Oxford: Clarendon Press, 1991), p. 46.
} 
been an 'artistic blunder'. ${ }^{32}$ While according to Wagner, Berlioz recognised the insubstantial nature of absolute music and 'forced' meaning upon his symphonic music through the employment of rhetoric devices, Berlioz, (unlike Wagner), had supposedly not taken the right path after Beethoven's most significant masterpiece, the Ninth Symphony. ${ }^{33}$ I would argue, however, that through Lélio, Roméo et Juliette, and La damnation de Faust we can uncover how Berlioz perhaps did after all manage to create that mystical theatre of the imagination that Wagner himself had longed for. If we are willing and able to read the visual traces Berlioz has scattered throughout his musical offerings, our own imaginary theatres open before us.

Berlioz was a quintessential nineteenth-century composer and his place within his own historical context cannot be stressed enough. He not only engaged in the musical ideas of his time but also took an active interest in more general questions of aesthetics raging through early nineteenth-century Europe. It was Berlioz's own 'uncommon upbringing', instilling within him an impressive knowledge of both classical and modern literature that is significant when considering his works. ${ }^{34}$ Berlioz was not only a composer but also an avid reader and critic, devouring the works of Virgil, Shakespeare, Goethe, Thomas Moore, Byron, Victor Hugo, Alexander Dumas, and countless others. While Berlioz was a staunch supporter of the music of Weber, Beethoven and Gluck, the infusion of literature into Berlioz's

\footnotetext{
${ }^{32}$ Dahlhaus, Nineteenth-Century Music, p. 249.

${ }^{33}$ Ibid., p. 250.

${ }^{34}$ Jacques Barzun, 'Berlioz as man and thinker', in The Cambridge Companion to Berlioz ed. Peter Bloom (Cambridge: Cambridge University Press, 2000), p. 11.
} 
compositions cemented his reputation amongst his peers as an avant-garde Romanticist. Lélio, Roméo et Juliette and La damnation de Faust, are a particularly interesting group of compositions that stand apart from Berlioz's oeuvre. These three works certainly straddle both worlds of the concert hall and theatre in interesting ways. This in itself poses questions in terms of how the performance and reception of Lélio, Roméo et Juliette and La damnation de Faust can be understood. 


\section{Part One:}

Early semi-operas 


\section{Chapter 1: Lélio}

After a 'grand concert dramatique' on 9 December 1832, featuring the Symphonie fantastique with its sequel, Le retour à la vie, the composer's friend Joseph d'Ortigue wrote, 'Let the portals of Grand Opera be opened to Berlioz! ${ }^{35}$ While history has shown that the portals of l'Opéra were indeed seldom opened for Berlioz, (and even then, not opened very wide), Le retour à la vie is indeed an example of the interesting relationship within Berlioz's compositions between text, sound, and the visual body that will continue to interest the composer throughout his lifetime.

The melologue Le retour à la vie, was first performed in Paris in the hall of the Conservatoire on 9 December 1832. This was a significant event for Berlioz, and seen as a type of homecoming concert upon the composer's return from his Prix de Rome sojourn in Italy. Berlioz's concerns that his reputation would have been forgotten during his two years away proved to be ill founded and this already controversial composer received a warm welcome with a sold out return concert. The audience included many luminaries from the Paris artistic scene including Hugo, Dumas, Liszt, Pleyel, Cherubini, Schlesinger, Nourrit, Habeneck, Paganini, the Comte d'Argout and, most significantly (to him), Berlioz's former object of obsession, Harriet

Smithson. ${ }^{36}$ In letters home to his family, Berlioz reported that

\footnotetext{
${ }^{35}$ James Haar, 'The operas and the dramatic legend' in The Cambridge Companion to Berlioz, ed. Peter Bloom (Cambridge: Cambridge University Press, 2000), p. 84.
} 
the concert was a roaring success and received more than twenty (mostly) favourable reviews, (though Bloom notes that he can only find a measly seventeen... $)^{37}$ The new work premiered at this concert, Le retour à la vie, or Lélio as it is now more commonly known, was envisaged as a sequel to his Symphonie fantastique. Le retour à la vie takes place after the artist has awoken from his opium inspired dreams and gives us a series of six disparate musical numbers joined together and made whole by the monologues that introduce and explain each movement. Berlioz understood and intended this work as 'a logical continuation of the psychological progression in the life of the artist-hero of the symphony, transforming a nightmarish fixation into a rational expression of faith in the power of music. ${ }^{38}$ Bloom gives a clear and succinct overview of this sequel:

Waking from the savage visions of the opium dream and warming to life by degrees, the artist-hero recalls the image of his beloved leading an infernal dance around his tomb; he wonders if his friend Horatio heard the cries of his fitful nightmare; he hears Horatio singing his favourite ballad (No. 1, Le Pêcheur). The artist compares his dubious fate to Hamlet's and imagines music for the ghost scene of that play (No. 2, Chouer d'ombres). He deplores the "crimes" committed against the works of sublime artists such as Shakespeare and Beethoven, and cries that in such a society he would prefer to be an outlaw (No. 3, Scène de la vie brigand). Returned to calm, he imagines himself crowned by love, happiness, and peace (No. 4, Chant du bonbeur, No. 5, Les Derniers soupirs de la harpe). Finally, descending from sublime heights and

\footnotetext{
${ }^{36}$ Hector Berlioz, Lélio ou Le retour à la vie, Hector Berlioz. New Edition of the Complete Works, Vol. 7, ed. Peter Bloom (Basel, London, New York, Prague: Bärenreiter, 1992), pp. xii - xiii. (Hereafter Lélio NBE).

${ }^{37}$ Ibid., p. xiii.

38 Ibid., p. ix.
} 
abandoning poetic illusions, he expresses ultimate faith in his own dramatic art (No. 6, Fantasie sur la Tempête). ${ }^{39}$

\section{A RETURN TO EARLIER COMPOSITIONS: THE GENESIS OF $L E$ RETOUR A LA VIE}

It is probable that Berlioz was at least planning this work before he left for Italy at the end of 1830, especially considering the fact he took his previous non-prize winning cantatas with him, music from which he would pillage for Le Retour a la vie. ${ }^{40}$ Though the Symphonie fantastique is often associated with Berlioz's obsession with Harriet Smithson, its sequel Le retour à la vie is not so much a recovery from the actress's hold on him, as a work that is better understood as the direct result of the drastic and dramatic events that happened after Camille Moke broke off her engagement with Berlioz. The story of how this sensitive composer immediately set out to commit a triple murder and suicide is well recounted in his own Memoirs as well as in various other biographies. His attempted suicide and subsequent recovery in Nice, led him to the (Beethovenian) realisation that he still had so much more to achieve in life and music. ${ }^{41}$ He thus began to piece together this almost cathartic composition. As Bloom explains, it was towards the end of his return to Rome that all of Berlioz's recent experiences 'came into perspective and the conception of Le retour à la vie came to

\footnotetext{
39 Peter Bloom, 'A return to Berlioz's "Retour à la vie"”, The Musical Quarterly, 64/3 (1978), 357.

${ }^{40}$ Bloom (ed.), Lélio NBE, p. viii.

41 This episode seems to resonate with Beethoven's own decision to live on for the sake of his art as is expressed in Beethoven's Heiligenstadt testament. This connection is alluded to in the text of the last monologue within Lélio. For a discussion of this see Bloom, 'A return to Berlioz's "Retour à la vie",, 374.
} 
life on paper. ${ }^{42}$ It would seem that just as the 'horrible truths' about Harriet Smithson functioned as a release from the psychological torment of his obsession with her, thus enabling him to compose the Symphonie fantastique, so too did the even more horrible truths about Camille Moke function as a catalyst in the composition of Le retour à la vie.

Perhaps one of the most significant complaints academics and audiences make about this work is its use of extensive selfborrowings - Berlioz bases all six musical movements on earlier compositions. However, this rescue of previous compositions from oblivion can be seen as quite appropriate considering Le retour à la vie is about Berlioz's own artistic and personal 'return to life'. That Berlioz would want to recover music that would otherwise be lost within larger, forgotten compositions reflects the programme set forth in the title of this work. Indeed, David Cairns states that Berlioz created Le retour à la vie almost with the sole intention of recovering musical moments that would otherwise be lost in works that were either not performed or not worthy of being performed in their own original contexts. ${ }^{43}$ The list of self-borrowings Bloom identifies makes clear the extent to which this is a re-composed work rather than an entirely new composition. ${ }^{44}$ It has been previously suggested that the opening 'Le pêcheur' was composed as early as 1826 or 1827, though Bloom has pointed out that this movement was probably composed while Berlioz was in Italy or at the very

\footnotetext{
${ }^{42}$ Bloom (ed.), Lélio NBE, p. ix.

43 David Cairns, Berlioz: The Making of an Artist 1803-1832 (London: André Deutsch Limited, 1989), p. 431.

${ }^{44}$ Bloom (ed.), Lélio NBE, pp. viii - xviii.
} 
earliest in 1828 after he was known to have encountered Goethe - part of the inspiration for this section. ${ }^{45}$ Apart from the ambiguous origins of 'Le pêcheur', the other movements are clearly derived from earlier works. The 'Chœur d'ombres' is a re-working of the 'Méditation' from his cantata Cléopâtre. Originally the language Berlioz used in the speech before this section was an 'oddly concocted "ancient dialect from the north" "46 While this dialect was published in the 1832 libretto, Berlioz used standard French speech when he revised the score in 1855 for a performance in Weimar. (Bloom maintains that Berlioz instead 'reserved the device' of using a made-up language for his La damnation de Faust.) ${ }^{47}$ The 'Chanson de Brigands' is most likely based on his now lost earlier setting of Humbert Ferrand's Chant du Brigand. The 'Chant de bonheur' is a revision of the opening Introduction and Larghetto of his cantata La mort d'Orphée. 'La harpe éolienne' is a variation of a very brief orchestral excerpt, 'Tableau musical', from the same cantata. The final 'Fantaisie sur la tempête de Shakespeare' was composed in Paris before he left for Rome. Inspired by Camille Moke and her virtuosic piano playing, this final movement was intended to be understood as a work that could also function separately as a complete work as well as the finale to his episode in the life of an artist. Though by the premiere of Le retour à la vie Camille had disappeared from Berlioz's personal life, this movement did in fact go on to become a stand-alone finale.

\footnotetext{
45 Ibid., p. xi.

46 Ibid., p. xi.

${ }^{47}$ Ibid., p. xi. Indeed a closer inspection reveals these two languages to share many similarities, for example: 'merinunda' 'meror' 'moretisfo' (Lélio) and 'merikariba' 'merondor' 'Méphisto' (La damnation); moreover, both texts repeat lines, as if chanting an incantation.
} 
Cairns points out in his amusing article 'Berlioz and Criticism: Some Surviving Dodos' that the act of self-borrowings wasn't new and certainly isn't a practice restricted only to Berlioz as opposed to other nineteenth-century composers. ${ }^{48}$ These borrowings do not necessarily depict a mind devoid of invention, in fact as already suggested, these borrowings could add to the programme of this work. Le retour à la vie is a work that is very much found in the sum of all of its parts. The inclusion of extensive monologues and the clear theatrical element intended for this work make Le retour à la vie much more than a mere patchwork of early compositions. As Cairns highlights, Le retour à la vie, though first performed at the hall of the Conservatoire, was intended to be performed in a theatre, with the performance forces hidden behind the curtain, 'so that until the curtain rises on the final number, the Tempest fantasy, the music is imagined as taking place in the mind of the protagonist. ${ }^{49}$ The psychological and theatrical imagining of this music, so clear in Berlioz's intention, is pivotal to our understanding of this work. Cairns implores us, 'do not use the extravagances and absurdities of Lélio (if that is how the work strikes you) to prove that Berlioz was always "like that"; a little historical imagination about the circumstances which produced it, the cultural atmosphere and fashions of the time, and the age of the composer, will work wonders. ${ }^{50}$ Cairns is essentially apologetic in tone, but his plea that this work should not be understood only within the context of our own performance practices is pivotal in coming to terms with, and giving

\footnotetext{
48 David Cairns, 'Berlioz and Criticism: Some Surviving Dodos', The Musical Times, 104/1446 (1963), 548-551.

49 Cairns, The Making of an Artist, p. 430.

${ }^{50}$ Cairns, 'Berlioz and Criticism: Some Surviving Dodos', 550.
} 
significance to, the theatrical effects that Le retour à la vie contained for the work's original audience. How this intended theatrical performance may have highlighted prevalent ideas and meanings for Berlioz's audience deserves closer attention.

\section{DRAWING A LINE IN THE SAND: THE BEGINNINGS OF A DRAMATIC MUSICAL REVOLUTION AND LITERARY PRECEDENTS IN THE LIBRETTO}

An understanding of the artistic climate in Paris can illuminate essential approaches to dramatic narrative beginning to be explored by both Berlioz and his contemporaries. The original subtitle of Le retour is often a point of concern for modern audience members. The form of the melologue - a mixture of dramatic spoken texts and musical movements - certainly contributes to the lack of modern performances. There is a general feeling that the style of the libretto is too sentimental, and the form of delivery perhaps highlights its uncomfortably serious nature. ${ }^{51}$ The term 'melologue' is defined in the Oxford English Dictionary as a 'musical performance, in which some of the verses are sung and others recited. ${ }^{, 52}$ The Irish poet Thomas Moore first coined the word melologue in 1820, conflating the words monologue and melodrama to describe a work of William Collins. Moore defined his term as 'that mixture of recitation and music, which is frequently adopted in the performance of Collins's Ode on the Passions. ${ }^{, 53}$ Berlioz based his own melologue on Moore's On National Music, A Melologue,

\footnotetext{
51 Bloom, ‘A return to Berlioz’s “Retour à la vie” ', 385.

52 The Oxford English Dictionary, Vol. IX 'Look - Mouke', ed. J. A. Simpson and E. S. C. Weiner (Oxford: Clarendon Press, 1989), p. 586.

53 Ibid., p. 586.
} 
which Berlioz had read, though he had not heard the accompanying music. Racine's Athalie was later understood as a type of melologue. ${ }^{54}$ Thomas Moore was very popular in France throughout the nineteenth century, and this poet was certainly a great inspiration to the young Berlioz, as seen in his Mélodies Irlandaises. The use of the term melologue, therefore, should not just be added to the long list of Berlioz bizzarreries; rather, it was a term that would have been recognised by the more wellread members of his immediate audience. Whereas Vera Micznik states that the use of the melologue is simply a way in which Berlioz can create a piecemeal work that exhibits very little unity if any at all, an examination of the many literary allusions within Le retour à la vie may be more fruitful to an understanding of how this work functions as a whole and the dramatic impact Berlioz's composition may have had for its original audience. ${ }^{55}$ Might there be other standards by which we can judge the success of this work other than its apparent absence of unity?

It was while Berlioz was in Italy, from the end of 1830 to 1832 , that he composed the majority of the original libretto, often while walking in the Italian countryside. Berlioz made extensive use of the writings of Hugo, Shakespeare, and his good friend Humbert Ferrand et al., significantly employing the latest literary trends. In a preface to this work Berlioz describes his libretto as being in 'prose cadence' as opposed to the more traditional

\footnotetext{
${ }^{54}$ Cairns, The Making of an Artist, p. 431.

55 Vera Micznik, 'The Musico-Dramatic Narrative of Berlioz's Lélio' in The Musical Voyager: Berlioz in Europe, ed. David Charlton and Katharine Ellis (Frankfurt am Main: Lang, 2007), pp. 184-207.
} 
rhymed verse. ${ }^{56}$ This term illustrates the extent to which Berlioz was engaged with and drawing allusions to the ideas and works of other Romantic literary artists working in Paris and greater Europe at this time. The term prose cadence refers specifically to the style of text in the plays of Victor Hugo and Alexander Dumas. Their use of prose in Hernani and Henri III et sa cour, respectively, broke down the traditional French literary and theatrical practice of using versified text. As Bloom states, 'Serious spoken drama in France at that time was usually (and traditionally) in regular rhymed Alexandrine verse. ${ }^{57}$ Dumas's play Henri III et sa cour was written entirely in prose. The use of alexandrines, treated using the technique of enjambment to create the impression of prose, was employed in Hugo's Hernani. Indeed, Hernani was established, even before its premiere, as being a revolutionary play, questioning the traditional classical practices of French theatre. All too soon, the Classicists and the Jeune-France were at war. Cairns describes this epic battle in appropriately colourful terms:

The Classicists, the 'perruques', having failed to stop the play being put on, had arranged to hiss it off the stage; but the Jeune-France turned out in force to frustrate them. Organised in platoons under designated leaders (Gérard de Nerval commanded one, the eighteen-yearold Théophile Gautier, in outrageous pink waistcoat, another), issued by the playwright with passes coloured red and bearing the Spanish word 'Hierro' (iron), beards untrimmed and hair left to grow long as a gesture of contempt for their 'baldpate' opponents, they took up their positions hours before the performance [...] The old guard fought hard, contesting the play night after night, but they were outfought. Each audacity was challenged and noisily defended. ${ }^{58}$

\footnotetext{
${ }^{56}$ Bloom (ed.), Lélio NBE, p. ix.

${ }^{57}$ Bloom, 'A return to Berlioz's "Retour à la vie" , 359.
} 
Both plays stirred a debate in Paris that began before Berlioz left for Italy and was still raging when he returned. That Berlioz was interested in Hugo's work is easily discernable from his Memoirs, letters, writings and compositions. In January 1829 Berlioz set Hugo's Chanson de Pirates and when he was stranded in Rome he was desperate to find and read the recently published Notre Dame de Paris. ${ }^{59}$ We know from letters to his sister Nanci that Berlioz was present at an early performance, if not the premiere of Hernani - that controversial play that inflamed the indignation of many conservative critics. ${ }^{60}$ Thus when Berlioz used the term prose cadence, the audience at the premiere of Le retour à la vie would have immediately recognised Berlioz's desire for his work to be understood within the context of this literary debate coursing through Paris. The Jeune-France movement was building momentum against the archaic practice of versified text in the theatres of France and Berlioz's Le retour à la vie should be understood as a statement from the composer illustrating his own views on the matter and identifying the side on which he was fighting.

Interestingly, Berlioz was not very impressed with Hugo's Hernani, feeling that his enjambed verse should have been entirely in either prose or verse form, not something in between. In this same letter Berlioz goes on to state that Hugo's

${ }^{58}$ Cairns, The Making of an Artist, p. 323.

${ }^{59}$ Bloom, 'A return to Berlioz's "Retour à la vie" ', 375. For a description of his eagerness to find a copy of Hugo's latest work see Cairns, The Making of an Artist, p. 460. See also the letter from Berlioz to Victor Hugo dated 10 December 1831 in Hector Berlioz, Correspondance Générale: Volume I 18031832 ed. Pierre Citron (Paris: Flammarion, 1972), pp. 507-509. (Hereafter CG).

${ }^{60}$ See letter from Hector Berlioz to Nanci and Adèle Berlioz dated 20 April 1830, in Berlioz, CG vol. I, pp. 321-322. 
'more important innovations had to do with the breakdown of the unities time and place' as put forth in his preface to Cromwell. ${ }^{61}$ This preface, with its fervent message that Shakespeare should be seen as the epitome of drama and that the formal and highly regulated practices of French theatre were out of date and unrealistic, was to become a Romantic literary manifesto that can be seen to have had a continuing and significant impact on Berlioz's own compositional style. As Vera Micznik highlights, through Le retour à la vie 'Berlioz strongly affirmed his knowledge and support of Victor Hugo's reforms [as put forth in Hugo's preface to Cromwell], and thus his affinity with the revolutionary ideals of his time. ${ }^{62}$ Micznik goes on to state that it is precisely this desire to incorporate Hugo's ideas into Le retour à la vie that gives Berlioz licence to create a fragmented and disparate work. Micznik argues that we can easily see Hugo's ideals reflected in the many languages, genres, the variety of subject, place and time found in Le retour à la vie. The many variations within the score are not used to achieve any 'narrative continuity' but rather to be recognised as a 'most outrageous rule-breaking, ${ }^{63}$ On the other hand, Bloom, perhaps less cynically, argues that 'What most interested Berlioz about the melologue structure was its dramatic nature: here was a new way of combining words and music into a theatrical entertainment that was neither opera nor drama (nor melodrama), but which resembled all three. ${ }^{64}$ Though the term melologue alongside its description of its libretto as 'prose cadence' clearly contextualises this work within the literary ideas

\footnotetext{
${ }^{61}$ Ibid., translation from Cairns, The Making of an Artist, p. 324

${ }^{62}$ Micznik, 'The Musico-Dramatic Narrative of Berlioz’s Lélio', p. 184.

${ }^{63}$ Ibid., p. 196.

${ }^{64}$ Bloom, 'A return to Berlioz's "Retour à la vie"”, 360.
} 
of its time, Berlioz is not simply being outrageous for the sake of being outrageous as Micznik implies. Berlioz is using literary ideas to expand the horizon of what is possible within dramatic musical forms and trying to find ways of going beyond opera and drama to create something new. It is this ability to see new possibilities within form and genre itself, inspired by parallel reforms in literature and the theatre, that is perhaps Berlioz's saving grace when he is later confronted with barriers to performance from the conservatism of the governing musical institutions of Paris. His abilities to channel these setbacks into works that could be performed in other contexts ensured that his music could still be heard in his homeland.

\section{TO BE [HORATIO] OR NOT TO BE [HORATIO], THAT IS THE QUESTION: A CHANGE OF NAME AND NEW MEANINGS}

Throughout this study it is possible to see how the titles and subtitles of Berlioz's compositions play an integral part in our understanding of their overall programmes. Therefore, Berlioz's decision to change the title of his sequel to the Symphonie fantastique immediately poses questions as to how this may affect new programmatic understandings within Le retour à la vie or Lélio as it is now more commonly known. I would argue that in order to fully grasp the effects of this name change, acknowledging the significant influence Shakespeare had on Berlioz, and the sacred position his plays held for this composer is essential. It seems impossible to write about Berlioz and not recognise the extent of his belonging not just to the musical world of the nineteenth century but equally to the literary world of the nineteenth century. To say he was well read is an understatement and Peter Bloom states emphatically that the 
'picture of nineteenth-century French literature would not be complete without Berlioz. ${ }^{65}$ When he revised Le retour à la vie for a public concert to benefit a retired musicians fund on the 21 February 1855 in Weimar, his changes continued to reflect literary forms and novelties pertinent to his time, and indeed while Berlioz made significant textural changes, there are very minimal musical changes.

It would seem that Berlioz was anxious to continue to use the subtitle of this work as a way of guiding the audiences' understanding of its genre and form. Berlioz changed the subtitle from 'mélologue' to 'monodrame'. In fact this second term, though perhaps more recognisable to audiences today, had never been used within a French context previously. ${ }^{66}$ Again, Berlioz was using English literary precedents, as well as one very important German literary source: the poems of the Englishmen Tennyson and Browning are often called monodramas and are considered to be inspired by Goethe and his only monodrama Proserpine. ${ }^{67}$ Though this is the only monodrama within Goethe's oeuvre, Bloom states that 'the opening soliloquies in [Goethe's] Faust are clearly monodramatic'. ${ }^{68}$ As the libretto of Le retour à la vie claims the narrator as a 'nouveau Faust' it seems significant that Berlioz was continuing to tie this autobiographical work to the work and style of Goethe, one of his greatest artistic influences. It is also significant that this change was made in Weimar, the

\footnotetext{
65 Ibid., 355.

${ }^{66}$ Bloom (ed.), NBE Lélio p. xiv.

${ }^{67}$ Ibid., p xiv.

${ }^{68}$ Ibid., p xiv.
} 
birthplace of Goethe. ${ }^{69}$ Berlioz went on to change large sections of his libretto as well as the title for its publication later on in 1855. His revisions to the music were minimal.

As previously mentioned, the sequel to the Symphonie fantastique is now mostly recognised by its later name Lélio. The origin of this new title is the cause of much contention amongst scholars. Bloom credits Jacques Barzun with first putting forward the theory, supported by D. K. Holoman, that it was Berlioz's friend d'Ortigue who first drew a connection between the subject of The episode in the life of an artist, and George Sand's novella La Marquise, which was published in the Revue de Paris during the same period as the premiere of Le Retour. ${ }^{70}$ Holoman quotes D’Ortigue's description:

An unknown English actress played the role of Ophelia in Hamlet and was justifiably admired for it. Berlioz saw her, and from this moment a sudden love, its cause and effect inexplicable, frightening in its violence and tenacity, seized his heart. Such a sentiment can only be compared with that singular passion of the marquise de $\mathrm{R}^{* * *}$ for the actor Lélio, which a gifted writer has described with so much skill in the Revue de Paris. ${ }^{71}$

Bloom disagrees with this theory, pointing out that considering the name of Le retour à la vie wasn't changed to Lélio until 1855 some twenty-three years after d'Ortigue made the comment in 1832 or 1833 - this seems an 'inappropriate' conclusion. ${ }^{72}$

Bloom offers his own theories:

\footnotetext{
${ }^{69}$ Ibid., p. xiv

${ }^{70}$ Ibid., p. xiv.

${ }^{71}$ D. Kern Holoman, Berlioz (Cambridge, Massachusetts: Harvard University Press, 1989), p. 138.
} 
In fact the name "Lélio" belongs to the repertory of stock characters of the commedia dell'Arte; it was given a lasting image... by Luigi Andrea Riccoboni (1676-1753), an actor who was himself widely known as "Lélio."

This character from the commedia dell'Arte appears in works by Molière, Marivaux and Goldoni all of which Berlioz knew. In his introduction to Lélio (NBE), Bloom puts forth a newer theory that Berlioz simply wanted to reinforce the autobiographical nature of this work by choosing a title that sounded similar to the his own name. Bloom maintains that Berlioz was often pronounced without the last consonant and his name would thus rhyme with Lélio. ${ }^{74}$

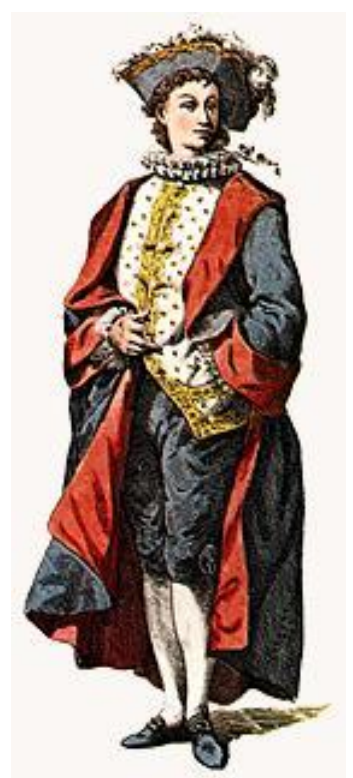

Figure 1: Maurice Sand's picture of the character Lélio from Masques et bouffons (1860).

\footnotetext{
72 Bloom, 'A return to Berlioz's "Retour à la vie”, , 361.

73 Ibid., 361.

${ }^{74}$ Bloom (ed.), Lélio NBE p. xv.
} 
Luckily, the motivations for revisions to the libretto itself are more easily determined. It was while revising Lélio for the Weimar performance that Berlioz substantially cut the tirade against those who didn't understand and appreciate the works of Beethoven. The times had changed and whereas these comments may have been appropriate for a Parisian audience of the early 1830s, one would be hard pressed to find a musician or musical commentator who would not agree that Beethoven was one of the greatest composers of all time. ${ }^{75}$ Perhaps some of the more interesting changes within this work occur around the many allusions to Shakespeare's Hamlet. Like the later works of Beethoven, this play was seen as barbarous by many in the 1820s in Paris. Allusions to Hamlet within Lélio's earlier manifestation would surely have been seen as another 'rallying cry... challenging those of ultraclassic sensibilities' ${ }^{76}$ The changes made to the Hamlet allusions within the text reflect a different and more personalised understanding of the character of Hamlet by the composer. In the original monologue preceding the final Tempest fantasy, it is the narrator who calls for the curtain to rise, revealing an orchestra comprised of Horatio's students and led by the narrator himself. In the revised version, the students are those of the Lélio, who tells them specifically how to arrange themselves and how to follow the directions of the conductor. As Bloom explains, these changes may 'reflect what Berlioz felt to be an understanding,

\footnotetext{
75 The text of the original libretto had included a tirade against those who felt it was necessary to 'arrange' and 'edit' Beethoven for the sake of good 'taste'. This monologue was obviously directed towards the critic F. J. Fétis who had himself made 'corrections' to Beethoven's scores and was well known for using the phrase 'beaucoup de goût'. See Bloom (ed.), Lélio NBE, p. x.

${ }^{76}$ Bloom, ‘A return to Berlioz’s "Retour à la vie" ', 370.
} 
greater in 1855 than in 1832, of Shakespeare's play-within-a-play technique. $^{77}$

I would argue that this revision also reflects Berlioz's own experiences of composing dramas that establish a similar theatre-within-a-theatre concept, or more interestingly, a theatre-within-a-concert concept. The performance instructions issued by the artist narrator and the act of consciously lifting the stage curtain are two very important and self-reflective elements in this work. We can see how Berlioz is exploring issues of visuality, the nature of spectacle and how an audience experiences music and drama. By asking the musical performers to create music behind a curtain, Berlioz is consciously making the audience aware of the fact that they are being asked not to watch an orchestra perform. Instead, with the help of the narrator, the music functions as a guide to the imagination and experience of the narrator himself. Thus Berlioz is creating a type of imaginary theatre, located in the sound of the orchestra but not in its physical representation. When Berlioz then lifts the curtain, he is asking the audience to then consciously watch the orchestra perform, making this performance specifically a concert. By raising a curtain and making the final movement alone a 'concert', Berlioz positions all that comes before, including his Symphonie fantastique, as something that is not a concert and is instead something else, perhaps something more dramatic and theatrical - a drama taking place in the theatre of the mind. We can see how this technique isn't so much analogous to Shakespeare's play within a play idea; Berlioz is instead using the self-reflection and awareness of the act of

77 Ibid., 370. 
performance to create a sense of differentiation between a concert and a kind of sonic music drama. This is a fascinating idea, especially when considering our own reception of Lélio. It is the text of Lélio, specifically the text guiding the method of performance that is integral to understanding the meanings of this work.

\section{$20^{\mathrm{TH}}$ CENTURY RECEPTIONS OF LÉLIO}

The fact that Berlioz revised Lélio substantially and changed both the title and subtitle at a later, more mature time in his life would indicate that he was eager to continue performing this work. Lélio's unique position within Berlioz's compositional output and its fascinating performance instructions suggest that we should not just examine Lélio as an expression of the youthful and high-spirited Berlioz, but also as a considered part of his compositional output. Yet this clearly hasn't been the case. Reviews from throughout the 20th century have all highlighted almost identical problems. What is the appropriate venue for such a work? With such disparate forces - combining sections for piano and voice, for chorus and orchestra, for orchestra and piano - how is such a work to be performed at all?

Berlioz throughout his lifetime and certainly throughout the twentieth century has been understood primarily as a symphonic composer and many critics have preferred to concentrate on the music of Lélio rather than the text. In a 1929 review of excerpts from Lélio, performed in Strasbourg at a restaurant of the Orangerie, 'a kind of Zoo garden pleasure resort', W. G 
Whittaker concentrates almost entirely on the 'real Berlioz' that is Berlioz, the composer of orchestral music. ${ }^{78}$ After describing the clever orchestration of the 'Choeur d'Ombres', it was finally 'with 'La harpe éolienne', scored for orchestra only, that one came to hear the real Berlioz - 'it revealed much charm'. ${ }^{79}$ In other words, this reviewer, who also sings the praises of the 'seldom performed' Symphonie fantastique, (!) considers Berlioz primarily a composer for the orchestra. The verses in praise of the brigands' music for example are something that must necessarily be ignored or one may, at best, be 'willing enough to laugh at them in musical comedy'.

By the 1950s it seems that Lélio had become obscure. While the diversity of forces required in the realisation of this work is often blamed for the paucity of performances, the greatest cause of concern for live renditions, according to the reviewer Edward Arthur Lippman, is the Romantic inclusion of those pesky texts from the composer's life. ${ }^{81}$ As Mr Lippman states in a review from 1954, 'a present day audience, unless it is inclined to a historical approach, will inevitably be uncomfortable when subjected to the Romantic confessions of an artist's private life. ${ }^{82}$ What is fascinating about the rest of the review is that

\footnotetext{
78 W. G. Whittaker, 'Berlioz's "Lelio": A Strasbourg Performance', The Musical Times, 70/1039 (1929), 814.

${ }^{79}$ Ibid., 815.

${ }^{80}$ Ibid., 815.

${ }^{81}$ Edward Arthur Lippman, review of 'Berlioz: Lélio or The Return to Life, Lyric Monodrama, Op. 14B. André Charpak, narrator; Joachim Kerol, tenor; Gabriel Baquier, baritone; Orchestra and Chorus of the New Paris Symphony Association, cond. René Leibowitz. 12” LP. Vox Pl 8250', The Musical Quarterly, 40/2 (1954), 276-279.

82 Ibid., 277
} 
Lippman offers up solutions to the problem of how and perhaps where one can perform this work. The phonograph seems to be his ideal way of enjoying this music. While the spoken monologues are evidently unwelcome in the concerthall, on a record player they are apparently more natural. Lippman feels that 'Lélio on records becomes surprisingly believable, if not convincing...music on records is not the same as music actually performed...In the case of Lélio, our mind's eye is able to accept what the hard reality of stage performance must make somewhat silly and embarrassing. ${ }^{, 83}$ In this moment of self-reflection, this reviewer has highlighted an issue that deserves contemplation for the performance of much of Berlioz's repertoire. In 1969, Hugh Macdonald again reiterates the unsuitableness of Lélio for the modern-day concert hall. In his review of a concert by the London Symphony Orchestra, Macdonald comments that 'Lélio in the concert hall sets the geese a-cackling about Berlioz's sanity and the supposed conceptual bizzarrerie of working out private obsessions in so theatrical a manner. ${ }^{84}$ Macdonald's review highlights the highly theatrical manner of Lélio, and the most problematic delivery of the monologues, to which he seems at a loss for a performance solution. But this review, like the one previously quoted begs the question, if Berlioz should not be performed in the concert hall than where should his music be performed, if it should be performed at all?

\footnotetext{
83 Ibid., 277

${ }^{84}$ Hugh Macdonald, review of 'Berlioz: Symphonie fantastique; Lélio. Barrault, Mitchinson, Shirley-Quirk/LSO Chorus/LSO/Boulez', The Musical Times, 110/1515 (1969) 497.
} 
These reactions towards Berlioz's melologue all highlight the fact that Lélio tends to be treated like a concert work and is performed in the same manner as a symphony or concerto. With this in mind it is soon understandable why it is the texts of the work that become problematic for audiences. However, Berlioz specifically stated that the first five movements should be performed in the theatre behind a curtain. While this may initially seem like an insignificant and rather eccentric request, this performance instruction does contain within it important implications. With the narrator as the only visible performer, the musical pieces that frame his monologues function to transport us into the very mind and imagination of the narrator himself. The fact that music was felt to be able to communicate ideas and emotions beyond the capabilities of text was a common nineteenth-century preoccupation. ${ }^{85}$

Thus only with the combination of the words, (concrete) and the music, (unknowable) could we hope to comprehensively understand and sympathise with the artist-hero. The final piece, intended also to be able to function as a stand-alone work, is experienced as if our guide has navigated us out of his innermost thoughts and returned us back into our uncomfortable seats at the theatre watching a work being performed. And it is this idea of watching rather than listening that we must address here. As Richard Leppert has illustrated in The Sight of Sound, before the advent of recording technology, music was always something that was experienced visually as well as sonically. ${ }^{86}$ Thus when an audience went to see a new work performed, it saw bodies and instruments manipulated into creating sound. The twittering of a bird alluded to in music would have a visual association not only with the image imitated but also with a

${ }^{85}$ E. T. A. Hoffmann famously set the ball rolling in the debate between absolute and programme music when describing Beethoven's Fifth Symphony as music that 'leads the listener imperiously forward into the spirit world of the infinite!' E.T.A. Hoffmann, 'Beethoven's Instrumental Music' in Source Readings in Music History, Vol. V, The Romantic Era, ed. Oliver Strunk (London: Faber and Faber Ltd, 1981), p. 38.

${ }^{86}$ Richard D. Leppert, The Sight of Sound: music, representation, and the history of the body (Berkeley: University of California Press, 1993). 
real person playing a flute. ${ }^{87}$ Today we no longer have these same associations. More often than not, we can hear Berlioz's Symphonie fantastique or Lélio in the comfort of our living rooms, or through our iPods while waiting for the bus. Music has become entirely abstract and devoid of any necessary visual accompaniment through modern technology. Significantly, it is this visual experience of musical narrative that Berlioz was experimenting with in Lélio and it is this same visual experience of Lélio that we have perhaps lost today. Jim Samson, employing fundamental principles of semiotics, claims that music functions on three levels: social cause, social trace and social production of meaning. It is the third that is salient in our understanding and the ongoing reception of Lélio. The third level put forth by Samson is that music is contingent on 'any certain time of reception'. ${ }^{88}$ Different peoples and cultures hear music differently at different periods in history. Therefore any meaning that music contains is changeable to the point that 'its identity can slip away from us. ${ }^{89}$ Within a musical culture that no longer necessarily has a visual experience of music production tied to an aural one, perhaps some of the meanings of Lélio have been lost. It is understandable why modern audiences find the delivery of such monologues so uncomfortable when they are so rarely a part of our own experiences of musical performance and musical values within the concert hall. In creating within our own imaginations a historical perspective, we can begin to restore this important separation of sound and the physical body, made conscious by Berlioz's curtain, and thus better understand how these monologues introducing each musical interlude are as essential as the music.

\footnotetext{
${ }^{87}$ Ibid.

88 Ibid., p. 10.

${ }^{89}$ Ibid., p. 10.
} 


\section{RE-CREATING THE IMAGINARY THEATRE IN LÉLIO}

Berlioz is particularly concerned with how Lélio is experienced visually. Throughout Lélio, the spoken texts are peppered with very specific dramatic instructions. From the very start, Berlioz is particular as to how this work should be performed. Lélio is instructed to enter from the wings in front of the curtain. ${ }^{90}$ During the music of the 'Chœur des Ombres', he must either pick up a volume of Shakespeare from the table provided and read or he can listen to the music wistfully and broodingly. ${ }^{91}$ In the third monologue, before the 'Chanson de brigands' the narrator (Berlioz/Lélio/Horatio) describes for us 'a concert of screams of horror accompanied by an orchestra of carbines, sabres, and daggers, blood and lachryma-christi, a bed of lava lulled by earthquakes. ${ }^{92}$ As Julian Rushton points out, the music recreates this scene, and 'reflects this fantasy by a series of shocks both motivic and harmonic... ${ }^{93}$ Indeed the opening fanfare initially indicates an unambiguous F major; however, all too soon things become 'wilfully angular' - by the third bar we have a flattened chord VI with an added augmented $6^{\text {th }}$. The expected dominant of $\mathrm{F}$ is instead replaced with a tonic $6 / 3$ chord which in itself is approached unusually. The rate of

\footnotetext{
90 'Il entre par l'un des côtés de l'avant-scène.' Berlioz, Lélio NBE, p. 3.

91 'Il semble écouter pendant les premières mesures du morceau suivant. Puis il prend sur une table un volume, l'ouvre et va s'étendre sur un lit de repos, où il reste pendant tout le Chœur d'ombres, tantôt lisant, tantôt méditant' Ibid., p. 7.

92 'un concert de cris d'horreur accompagné d'un orchestre de carabines, sabres et poignards, du sang et du lacryma-christi, un lit de lave bercé pas les tremblements de terre' Ibid., p. 23.

93 Julian Rushton, The Musical Language of Berlioz (Cambridge: Cambridge University Press, 1983), pp. 14-15.
} 
harmonic change increases before this sequence is then repeated from bar eight to bar seventeen. ${ }^{94}$ (Ex. 1.1)

I would argue that the shocks don't only come from the various harmonic surprises of this piece but also from the text of the song itself. Le Capitaine and his men sing of how they drink from the skulls of their enemies, Nous allons boire à nos maîtresses /Dans le crane de leurs amants!' ['We drink to our masters in the skulls of their enemies!'] Following this statement, made several times, there is always an ominous falling figure from the strings and woodwind carried down through the brass section. (See Ex. 1.2) The harmonic progression of this repeated figure is appropriately strange, with its $\mathrm{E}$ minor tonality being far removed from the home key of $\mathrm{F}$ major. Rushton claims that to 'rationalize it as a mediant of $\mathrm{V}$, or dominant of iii, would be absurd in this context; it is a thickening of a unison, the root-position chords enhancing the broad melodic steps. ${ }^{95}$ This harmonic colouring doesn't only capture the wonderful sense of horror from this grisly statement but this descending movement is also vaguely reminiscent of the head-chopping incident in the Symphonie fantastique. (Ex. 1.3)

\footnotetext{
${ }^{94}$ Ibid., p. 16.

${ }^{95}$ Ibid., p. 17.
} 

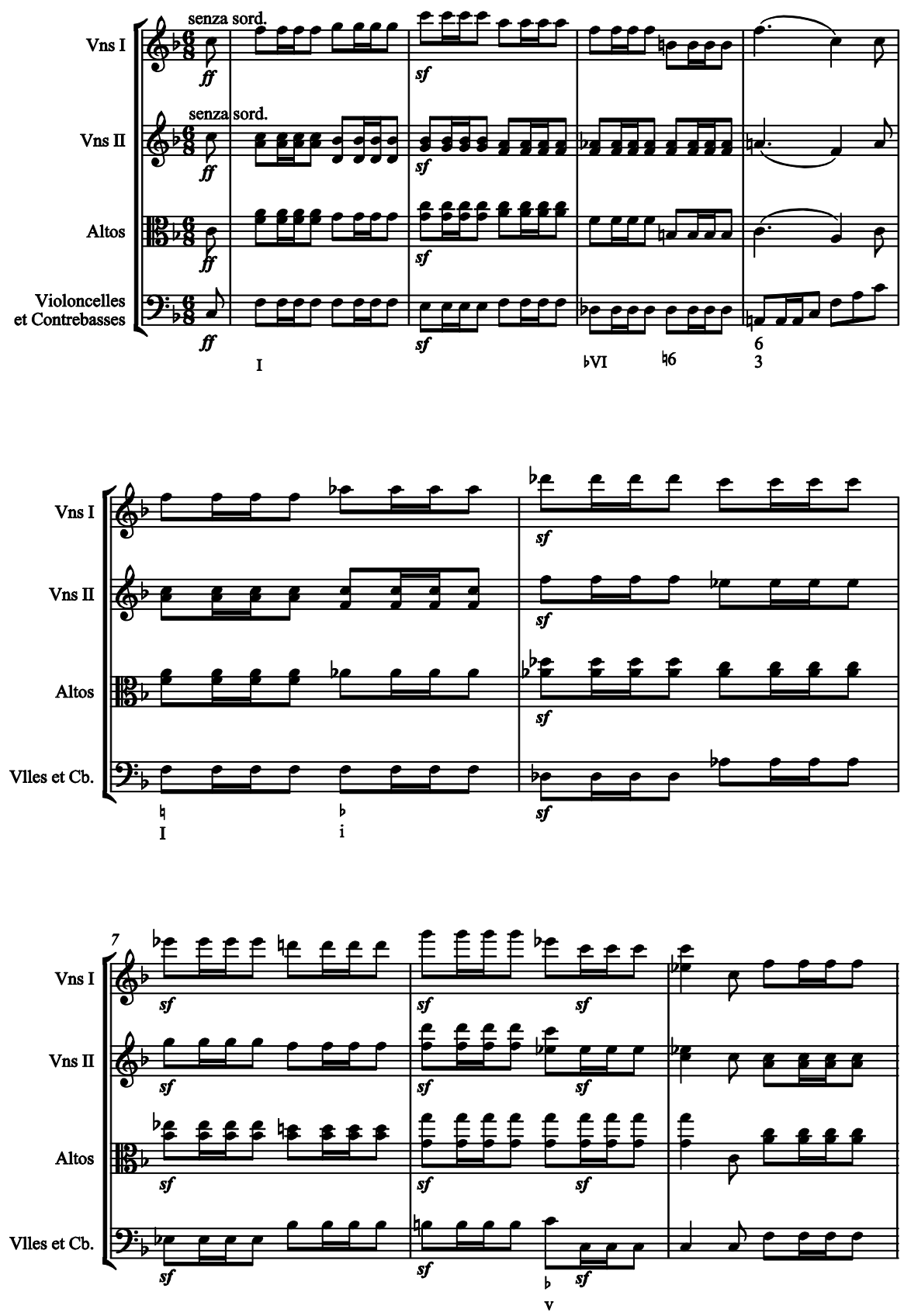

Example 1.1 Lélio bars 1 - 9, Opening fanfare. 


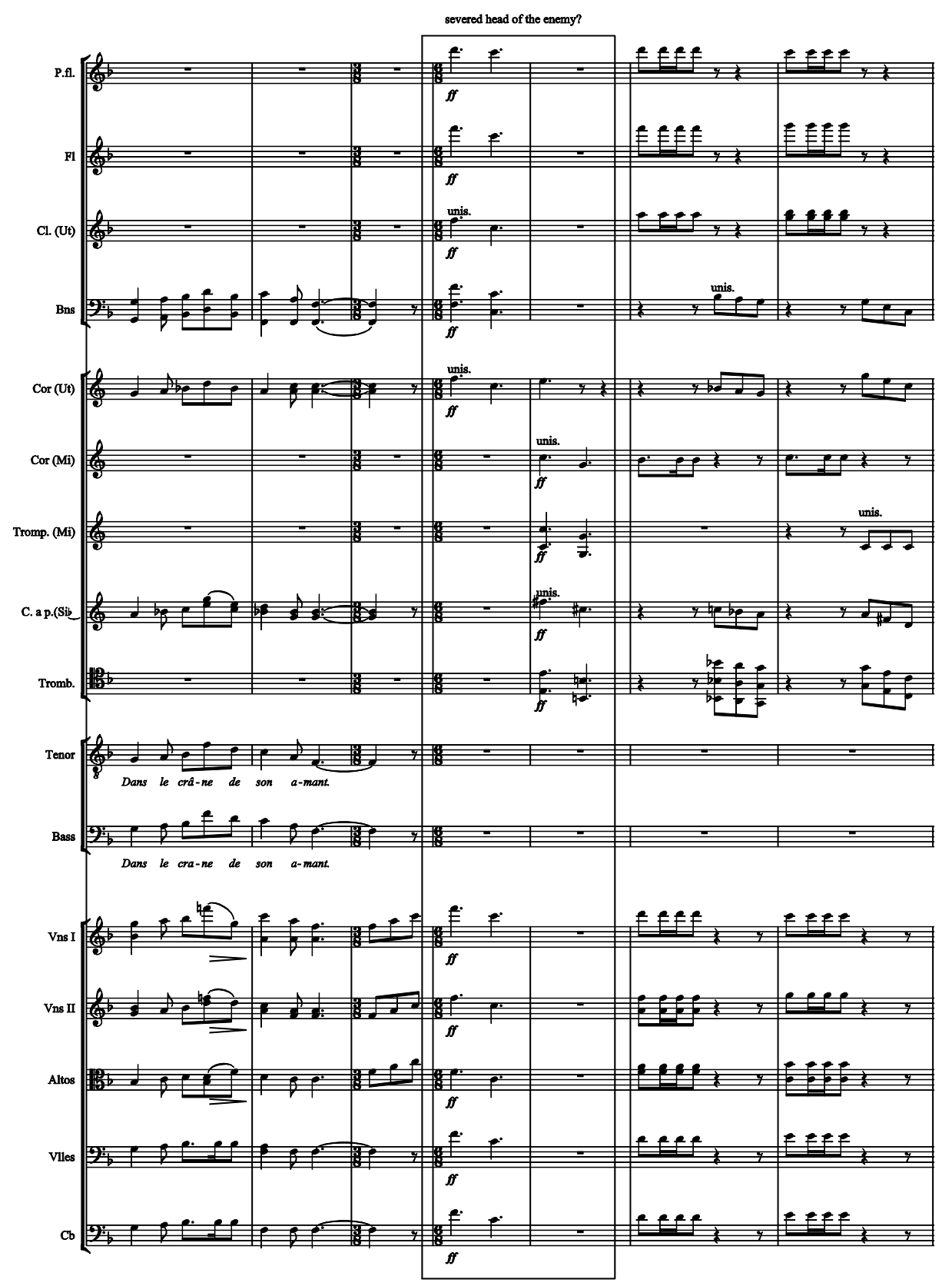

Example 1.2 Lélio bars 91 - 97. 


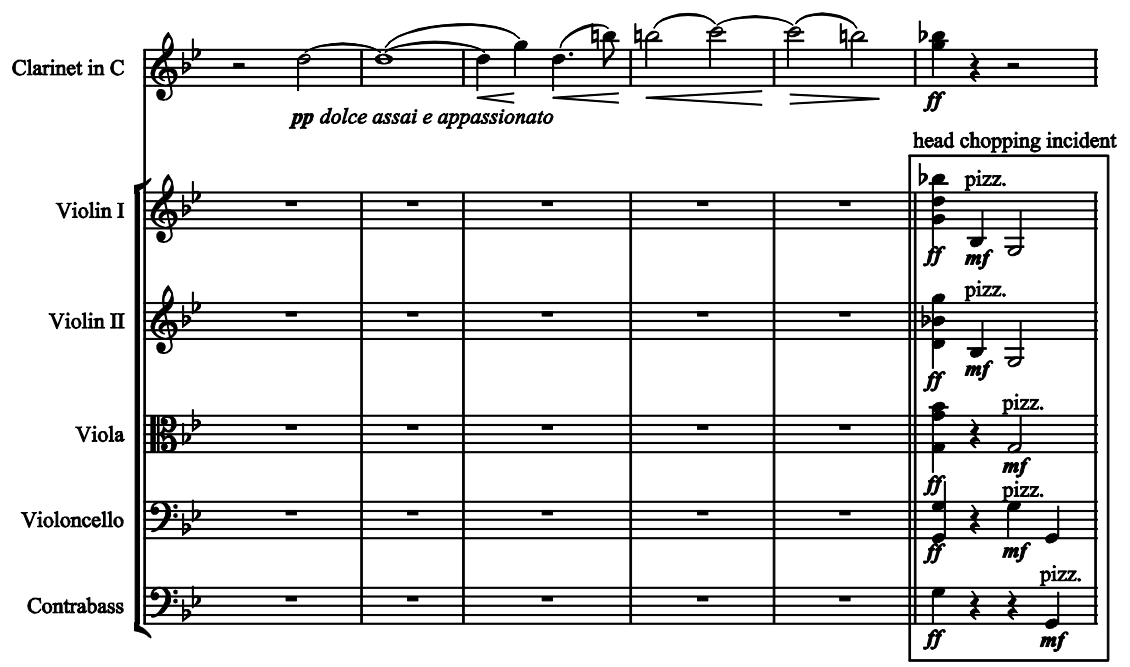

Example 1.3 Symphonie fantastique, 'March au supplice' bars 164 169.

As everything is performed behind the stage curtain, the audience is allowed to imagine these images in the "theatre of the mind' without the distraction of the instrumentalists and conductor. However, the audience is being distracted by the narrator. Indeed while the orchestra, solo bass and chorus perform behind a curtain, the narrator is given more specific performance instructions by Berlioz: after Lelio finishes his melologue 'il sort un instant et revient tenant à la main un chapeau de brigand Romain, avec le cartouchier, la carabine, le sabre et les pistolets. Pendant l'exécution de la chanson de Brigands sa pantomime exprime la part qu'il prend en imagination à la scène qu'il croit entendre.' ['He leaves for a moment, and returns holding in his hand a helmet of a Roman brigand, with a cartridge belt, rifle, saber and pistols.

Throughout the performance of the song of the brigands, his mimed actions express how he imagines the part he plays 
himself in music he thinks he hears.'] ${ }^{96}$ This is no longer music or a concert but a soundtrack to a terrible and thrilling drama, being re-enacted out in front of the audience by the narrator and through the music. After the music has finished, Berlioz stipulates that there should be a long silence. The narrator comes to his senses and puts down his arms. He goes into a dreamy state for a while, and sighs before launching into his next description completely calmly. ${ }^{97}$ The direction before and after the 'Chanson du brigands' is certainly the most lengthy, energetic and specific. The remaining instructions concern various sighs and moping at his table. These performance instructions certainly express the extent of Berlioz's concern with the visual aspects of the performance of this work, an aspect that has long been lost in modern performances of this work.

Berlioz's desire to have Lélio performed in a theatre would have only added to this sensory illusion. An audience from 1832 would have been well used to seeing spectacle at the theatre. In Listening in Paris, James H Johnson relates how the first half of the nineteenth century was governed by the boulevard theatres, grand opera and ballet. ${ }^{98}$ The later two especially were held in such high esteem precisely because of their visual grandeur and opulence. The ballet Psyché by Pierre Gardel was first premiered at the Opéra in 1790 and was so visually opulent and decadent,

\footnotetext{
${ }^{96}$ Berlioz, Lélio NBE, p. 23. All translations for Lélio are mine.

97 '(Long silence...Sa furieuse exaltation semble se dissiper...Il quitte ses armes. L'attendrissement le gagne peu à peu. Il pleure à sanglots. Puis son émotion s'adoucit...Il rêve quelque temps, soupire, et enfant essuyant ses larmes, il dit avec plus de calme.)' Ibid., p. 58.

98 James H. Johnson, Listening in Paris: a cultural history, (Berkeley: University of California Press, 1995).
} 
it remained active in the repertoire until 1829. It was performed 1, 161 times, outshining the works of Gluck, Rameau or Lully. ${ }^{99}$ In a review of Meyerbeer's opera Robert le diable, Berlioz describes a visual and aural feast:

$[\mathrm{H}]$ igh c's from every type of chest, bass drums, snare drums, organs, military bands, antique trumpets, tubas as big locomotive smokestacks, bells, cannons, horses, cardinals under a canopy, emperors covered in gold, queens wearing tiaras, funerals, fêtes, weddings, and again the canopy, the canopy beplumed and splendiferous, borne by four officers as in Malbrouck, jugglers, skaters, choirboys, censers, monstrance's, crosses, banners, processions, orgies of priests and naked women, the bull Apis, and masses of oxen, screech-owls, bats, the five-hundred fiends of hell, and what have you - the rocking of the heavens and the end of the world, interspersed with a few dull cavatinas here and there and a large claque thrown in. ${ }^{100}$

These operas and ballets were events that were vividly chronicled, and one can imagine the visual extravaganzas Parisian audiences had grown accustomed to. Berlioz adored the opera but as his somewhat ironic description highlights, to Berlioz the grandeur of grand opera sometimes seemed to arise as much from the visual as from the musical. The cavatine are still 'dull' and predictable; the audience claps because a section of it is payed to do so. I would argue that with Lélio, Berlioz might have had the intention of making his music all the more shocking and effective in its suppression of the visual dimension precisely because of the magnificent visual experience and expectations of the audience sitting in an environment so closely associated with such sensory opulence. One can imagine the effrontery of sitting down in a theatre only to have the curtain

\footnotetext{
${ }^{99}$ Ibid., p. 175.

${ }^{100}$ Hector Berlioz, Evenings with the Orchestra ed. and trans. Jacques Barzun (Chicago: Chicago University Press, 1999), p. 109.
} 
remain closed. Yet it is precisely this lack of action, this absence of bodies and scenery that is instead accompanied by visually descriptive monologues and the gestures of the narrator alone, alongside the exciting and evocative music that would enable the audience to take their own flights of fancy. On the stage behind that heavy curtain they could recreate within their minds the images of so many operas they had seen already decadently displayed. The triumph of Berlioz is that in the case of Lélio the music will not be drowned out by any visual splendour but will be the only way of gaining access to the drama put forth. The drama and visual splendour embodied within the music is projected onto the orchestra the audience knows is hiding behind the curtain. That this sense of spectacle is something that can be located in the sound of the orchestra and soloists will become a preoccupation of Berlioz's that he will return to in later dramatic compositions.

TYING THE CRAVAT: HOW AN ORCHESTRA CAN BEGIN TO SPEAK

That Berlioz was so successful and well known for his striking ability to convey specific events and emotions in his music alone, we can see from the fact he became the victim of parody at the very centre of opera and ritual in Paris. Two years after the premiere of Le retour a la vie, Berlioz was the subject of ridicule at the annual Opéra masked-ball. The scene is humorously recounted in Cairns' Servitude and Greatness. Cairns recounts how the actor Arnal was dressed in a 'flaming auburn wig' and mimicked Berlioz conducting an Episode in the Life of a 
Gambler. ${ }^{101}$ This descriptive symphony was composed for this occasion by Adolphe Adam and came complete with a 'Lélio-like commentary.' Cairns himself quotes the text from the monologue:

It's all in my orchestra, gentlemen. You will see the character in action, you will hear him speak, I shall portray him from head to foot; in the second reprise of the first allegro I will show you how he ties his cravat. The marvels of instrumental music! But that is only the beginning. Wait till you hear my second symphony on...the Civil Code. What a contrast between this kind of music, which dispenses with all those accessories that true genius has no need of, and to be understood merely requires - er - three hundred musicians - what a contrast, I say, with the ditties of Rossini. Rossini! Don't talk to me of him: an adventurer who presumes to have his music performed in every corner of the globe so as to acquire a reputation! A man who writes things any fool can understand! The charlatan! ${ }^{102}$

Though this seems like a somewhat cruel charade, Berlioz by all accounts, (including his own) could see the funny side. Yet this story is significant in that it illustrates just how original and aurally descriptive his music was understood to be by his audiences. ${ }^{103}$ As a type of backhanded compliment it seems that if any one could portray the tying of a cravat within the language of music, it was most probably Berlioz!

\footnotetext{
101 David Cairns, Berlioz: Servitude and Greatness: 1832-1869 (London: Allen Lane, The Penguin Press, 1999) p. 54.

102 Ibid., p. 54.

103 Though this story might portray Berlioz to be an extremist, the seminal works of figures such as Abbate, Cusick and Smart have uncovered the extent to which many $19^{\text {th }}$-century musical works are aurally descriptive, exposing many different narratives and gestures. In the groundbreaking Unsung Voices, Abbate develops a critical framework in which to explore music and uncover any number of different musical narratives and events. Her essay 'Music: Drastic or Gnostic' is a call to consider how meaning and narrative is embodied in the act of performance itself - be that as automative slave or wild and autonomous soprano. Smart, in Mimomania, and as editor for a collection of discussions on gender and sexuality in Siren Songs, situates musical moments within their historical contexts and exposes a myriad of different and often contradictory messages.
} 
It was inevitable that an artist, such as Berlioz, raised and encouraged to be passionate about the literature of Molière, Boileau, La Fontaine as well as Chateaubriand, Rousseau and Virgil, should have such a vivid imagination. His voracious appetite for reading would have created a method of imagining that was obviously naturally inclined to conjure up images more splendid than those he witnessed in real life. Therefore it is unsurprising that Berlioz's own approach to composing dramatic words was to focus and distil the drama, the grandeur, the very essence of tragedy, comedy or both within the music itself, trusting in one's imagination to provide a more than adequate visual accompaniment. That he was preoccupied with the most recent literary trends and debates is made obvious in the content of Lélio, especially in the complex web of allusions to Hugo, Moore, Goethe and Shakespeare contained within this work. The influence of opera on Lélio is not lost either. The fact that Berlioz wished for this work to be performed in a theatre meant that, hopefully, some sense of that same operatic drama would be more readily infused into the reception of this work. Berlioz's concern with the visual aspect of narration, and the symbiotic relationship between programmes and their physical performance has been much neglected by scholars. Through this work we can see how hiding away the musical bodies that created sound, Berlioz has relocated this sound onto the narrator himself. This sound can then be seen as an extension of his own thoughts and imagination, creating a kind of fledgling theatre of the imagination. Berlioz's preoccupation, not just with creating a programme, but in determining how this programme is communicated both sonically and visually, can be seen throughout Berlioz's oeuvre. Indeed we will discover that 
what Berlioz is exploring in this work is built upon and made more complex in his more mature works Roméo et Juliette and La damnation de Faust. 


\section{Chapter 2: Roméo et Juliette}

Whereas Daniel Albright defines Lélio as an 'apprentice semiopera', Roméo et Juliette is considered to be a fully fledged 'semi opera'. ${ }^{104}$ Indeed in the intervening seven years between Lélio and Roméo et Juliette Berlioz had grown significantly as a composer. He had written and performed an opera at the infamous Opéra, composed major religious works performed at state events, and become a well recognised critic. Roméo et Juliette goes a step further than Lélio, turning what may have comprised the spoken monologues into sung text. This later work can be seen as a move away from the literary tendencies that dominate Lélio and towards more overtly operatic ideals.

At the bottom of the autograph score of Roméo et Juliette there is a note that states: 'This symphony, begun on 24 of January 1839, was finished on 8 September of the same year and performed for the first time at the Conservatoire under the direction of the composer on the following 24 November. ${ }^{, 105}$ While this statement is certainly accurate, it is widely known that Berlioz had been fixated on the subject of Romeo and Juliet since he first saw Shakespeare's play in the autumn of 1827. The production that Berlioz saw at the Odéon in Paris was performed by William Abbott's touring English company, with Charles Kemble as Romeo and Harriet Smithson as Juliet. The seed of this drama was to germinate in Berlioz's mind for the

\footnotetext{
104 Albright, Berlioz's Semi-Operas: Roméo et Juliette and La damnation de Faust.

105 Hector Berlioz, Roméo et Juliette, Hector Berlioz. New Edition of the Complete Works, Vol. 18, ed. D. Kern Holoman, (Kassel, Basel, London, New York: Bärenreiter, 1990), p. viii. (Hereafter Roméo et Juliette NBE).
} 
next twelve years before it blossomed into a work that is as unique in its conception and genre as it is expansive and varied in its scope. Perhaps it was precisely this long gestation of the subject within Berlioz's mind that has lead to the continued speculation on how audiences, performers and critics should understand and come to terms with this original composition a composition that contains obvious allusions to the traditions of grand opera as well as essential aspects of 'absolute' music.

\section{THE GENESIS OF ROMÉO ET JULIETTE: COSMOPOLITAN PARIS AND A PASTORAL ITALY}

The 1827 to 1828 performances of Shakespeare by the Abbott Company set fire to the imaginations of all who saw them, engulfing Paris in a craze for the Bard. As Peter Raby states: 'These evenings at the Odéon and other theatres in the presence of Hugo, Dumas, Alfred de Vigny, Émile Deschamps, Achille and Eugène Devéria, Delécluze, Delacroix, Gautier, SainteBeuve (the list can be extended almost indefinitely, to include people such as Alfred de Musset who were reported to have been there on the opening night, but were not) forms a defining Romantic episode; and it is part of that definition that Berlioz's experience, part artistic epiphany, part coup de foudre, took place at a public theatrical event. ${ }^{, 106}$ Abbott's company became well known throughout Paris and the previously little known Irish actress Harriet Smithson was the toast of the town. The librettist of Roméo et Juliette, Émile Deschamps, wrote that 'It was at that moment that M. Hector Berlioz spoke to me of his

106 Peter Raby, 'Shakespeare in Paris' in The Musical Voyager: Berlioz in Europe, ed. David Charlton and Katharine Ellis (Frankfurt am Main: Lang, c.2007), p. 209. 
project of a dramatic symphony on Romeo and Juliet... We worked out a plan of this musical and poetic composition; melodies and verses came to us in profusion, and the symphony appeared - ten years later. ${ }^{107}$ As already discussed previously, it was throughout this same decade of the 1820s that Berlioz was undergoing an artistic education that would remain influential throughout the rest of his life. During this decade Berlioz not only discovered the dramas of Shakespeare, but was also first exposed to all those essential musical, theatrical and literary works that would have such a profound effect on all artists of the nineteenth century. Throughout this decade Berlioz discovered the symphonies and string quartets of Beethoven, the poetry and melologues of Thomas Moore, the legends of Goethe, the avant-garde works of Dumas and Hugo. These artists and many others were to become a great crucible of influence; expressing and reflecting through various characters, tragedies and manifestos, Berlioz's own passions and philosophies. Their work would permeate nearly all of his compositions from this point onwards, and, as we have already seen, Berlioz, holding true to his Romantic aesthetics, would mix and mingle these as his inspiration took him.

Ten years after coming into contact with the myriad of influences that the modern cosmopolitan city of Paris could offer this young provincial hopeful, Berlioz was sent abroad to Italy on his Prix de Rome journey. Although struggling with the less progressive literary and musical scene in Rome, Berlioz was in the native country of Romeo and Juliet and their story continued to stir in his mind. While in Florence in February

107 Holoman (ed.), Roméo et Juliette NBE, p. viii. 
1831 Berlioz saw Bellini's I Capuleti e i Montecchi. Though Berlioz was less than impressed with Bellini's treatment of the opera, and at that time unaware that the Italian composer had taken the story from earlier native Italian sources rather than Shakespeare's drama, his comments in a review of the work are telling as to how Berlioz imagined an opera on Romeo and Juliet should be:

In my excitement I had already imagined a true opera on Romeo, worthy of Shakespeare's genius. 'God! What a fine subject' I said to myself, shivering with pleasure in advance, 'How it lends itself to music!' To begin with, the dazzling ball at the Capulets', where amid a whirling cloud of beauties the young Montague first sets eyes on 'sweetest Juliet', whose constant love will bring her to the grave; then those furious pitched battles in the streets of Verona, with the 'fiery Tybalt' presiding like the personification of anger and revenge, the glorious night scene on Juliet's balcony, where the lovers murmur the music of tender love, as sweet and pure as the watchful moon smiling down upon them; the dashing Mercutio and his sharp-tongued, fantastical humour; the cackling nurse; the stately hermit, even in his cell caught up in the tragic conflict of love and hate, and striving to resolve it; and then the catastrophe, extremes of joy and despair drained to the dregs in the same instant, passion's heat chilled in the rigour of death; and, at last, the solemn oath sworn by the warring houses, too late, on the bodies of their children, to abjure the feud which shed so much blood, so many tears. My eyes streamed just to think of it. ${ }^{108}$

Berlioz already has vivid pictures of what certain characters would be like and the particular scenes would be best for operatic treatment. With such a precise image of what an opera of Romeo and Juliet ought to be, it is unsurprising that Berlioz found Bellini's own interpretation wanting, especially considering the great differences between Bellini's opera with its libretto by Felice Romani and Shakespeare's play.

108 Berlioz, The Memoirs of Hector Berlioz, p. 141. 
Bellini's opera first opens in the house of the Capuleti who have all gathered, fearing an attack from the Montecchi. Capellio, the head of the Capuleti, and Tebaldo inform everyone that the head of the Montecchi, Romeo, who has just killed Capellio's son, is sending a messenger asking for peace. Tebaldo swears vengeance. Romeo arrives, disguised as the messenger himself, expressing great regret for the accidental death of his rival's son. Romeo suggests that a peace treaty should be sealed with the marriage of Romeo to Giulietta, but is informed that she is already promised to Tebaldo. The treaty is rejected and Romeo warns that more bloodshed will follow. While preparations for the wedding are taking place, Giulietta mourns her fate, wondering wherefore art thou Romeo? Lorenzo, the doctor of the Capuleti discovers Romeo now disguised as a Capuleti and learns that Romeo and his friends are planning to abduct Giulietta. The Montecchi launch an attack. The lovers are discovered and separated. Act 1 ends with both factions divided on stage. In the second act, Lorenzo provides Giulietta with a potion that will feign death, promising her that when she wakes her Romeo will be by her side. Meanwhile Romeo comes face to face again with Tebaldi and just as they are about to duel they hear a lament. They soon come to understand that it is Giulietta who is being mourned, and the antagonists are united in grief. Romeo arrives to mourn the death of his beloved and has her tomb forced open. Slumped beside her inanimate body, he swallows a vial of poison. Giulietta awakes and tells the surprised Romeo of Lorenzo's potion but quickly learns that 
Romeo has already taken a deadly poison. When he dies, Giulietta falls dead over her Romeo. ${ }^{109}$

In Bellini's and Romani's version there is no dazzling ball, no glorious balcony scene, no marriage, no Mercutio, no nurse nothing that Berlioz would have recognised as belonging to Shakespeare's tragedy. Twenty-five years later, Berlioz still seemed to be relatively unimpressed with this Italian opera on Romeo and Juliet. In a review of the work, performed at l'Opéra, Berlioz called this work 'one of the most indifferent of Bellini's scores' and considered his 'moderate instrumentation, without either side or bass-drums' lacking in drama and verve. ${ }^{110} \mathrm{It}$ is curious that Berlioz, in 1831, admits to already having an image of what a 'true opera' on this subject should encompass. It is also important to remember that a Prix de Rome winner could reasonably hope to go on to become an opera composer. Opera was very much the yardstick by which composers were assessed and judged, and Berlioz was very keen to establish relationships with librettists and opera impresarios.

While much of what Berlioz described as dramatically ideal when reviewing Bellini's work was not included in his own later version of this drama either, there is evidence that the story was taking musical, as well as poetical, shape in the composer's mind at this time. While still in Italy, Berlioz confessed to

\footnotetext{
109 Simon Maguire, et al. 'Capuleti e i Montecchi, I.' In The New Grove Dictionary of Opera, edited by Stanley Sadie. Grove Music Online. Oxford Music Online, http://www.oxfordmusiconline.com/subscriber/article/grove/music/O004891 (accessed August 9, 2009).

${ }^{110}$ Hector Berlioz, Mozart, Weber and Wagner, trans. Edwin Evans (London: William Reeves, 1969), p. 161.
} 
Mendelssohn how surprised he was that no composer had yet thought to set the famous Queen Mab speech to music. Berlioz, in his Memoirs, recounts walking in the Roman countryside with Mendelssohn: 'It was on a riding excursion [...] that I mentioned my surprise that no one had ever thought of writing a scherzo on Shakespeare's glittering little poem 'Queen Mab'. He was equally surprised, and I instantly regretted having put the idea into his head. For several years afterwards I dreaded hearing that he had used the subject. ${ }^{111}$ While Mendelssohn did not compose a Queen Mab scherzo, one of his most beloved compositions, A Midsummer Night's Dream was composed a little more than ten years later in 1843. Is it possible that this discussion inspired Mendelssohn in some way? Some of Berlioz's compositions from this same period were also later used within his Roméo et Juliette. His 1830 Prix de Rome cantata Sardanapale contains music that would later reappear in the symphony; themes are taken from his Ballet des ombres also of 1830. ${ }^{112}$ D. Kern Holoman points out that the cantata Cléopatre has an inscription taken from Juliet's meditation on her burial, and there are similar pulsating bass figures in both Clépattre's 'Invocation' and 'Roméo au tombeau des Capulets'. ${ }^{113}$ The relationship between this 'Invocation' and Romeo's scene in the Capulet's tomb exposes an interesting aspect about Berlioz's approach to dramatic composition - an awareness of the visual and spatial environment within narration. Stephen Rodgers labels this approach a type of 'acoustic physiology. ${ }^{114}$ While Cleopatra and Juliet are approaching their deaths from two very

\footnotetext{
111 Berlioz, The Memoirs of Hector Berlioz, p. 150n.

112 Holoman (ed.), Roméo et Juliette NBE, p. viii.

113 Holoman, Berlioz, p. 93; Holoman (ed.), Roméo et Juliette NBE, p. viii.

114 Rodgers, Form, Program, and Metaphor in the Music of Berlioz, p. 43.
} 
different psychologies - Cleopatra is facing death and the wrath of the gods whereas Juliet is about to feign death and is afraid of the horrors she might witness whilst still alive in the crypt - the implied spatiality is the same. To imagine a hollow ghastly space, like the inside of a tomb, is [...] equally valid for any voice that might occupy it - wicked queen or infatuated adolescent. ${ }^{115}$ We can begin to see why Berlioz, composing a scene for Cleopatra, might include an epigraph from Juliet. That the nature of these two compositions bear similarities implies that it is perhaps the same imaginary environment of a tomb that Berlioz is trying to evoke in his music. It is understandable that Berlioz wanted to re-use all of these beautiful themes from earlier compositions so as not to lose them within works that, on the whole, were unlikely to be performed again. The fact that so many works from this earlier period seemed appropriate to be inserted into Roméo et Juliette could also suggest that Berlioz associated this period from the late 1820 s and early 1830 s with a time in which he was immersed in and preoccupied with Shakespeare's play and its many images of love, despair and wonder. Like Lélio, it seems that the act of musical borrowing in itself is associated with the programmes and narrative meanings of Berlioz’s compositions.

\section{TROUBLE AT L'OPÉRA}

During the intervening years between these first poetic and musical expressions of what were to become his symphony, Berlioz was to experience both great success and great failure in his public career as a composer. It is the effect of these failures and successes that can partly explain why Berlioz's dramatic

115 Ibid., p. 43. 
symphony Roméo et Juliette is so generically ambiguous or, perhaps, why it is a dramatic symphony and not an opera. As already discussed, Berlioz was primarily understood both during his lifetime and posthumously as a symphonic composer. While his symphonies did bring him much praise, his operas were often found to be too difficult. This was to be a great disappointment to Berlioz, especially as success within France was only ever measured by the triumphs or lack thereof at l'Opéra. Despite the fact that Berlioz's symphonies were praised as dramatic, evocative, or simply curious they could never replace the rewards of a successful opera within the public's eyes. Roméo et Juliette was composed relatively early in Berlioz's career, yet he had already suffered the bitter disappointment of a failed opera. Berlioz's first publicly performed opera Benvenuto Cellini had its premiere at l'Opéra on 10 September 1838. David Cairns has described l'Opéra as a 'famous death trap', Verdi once called it a 'nest of adders' and Berlioz himself later thought of it as 'the enemy of music'. ${ }^{116}$ Berlioz complained, often quite publicly, that l'Opéra only performed the works of dead or wellestablished, (may we even suggest conservative), composers, never allowing young composers, such as himself, the opportunity to establish themselves. Indeed the massive and cumbersome machine that was l'Opéra, combined with critics eager to exact revenge on Berlioz, and his well-known contempt for a lot of the operas performed at this esteemed establishment, were large factors in the failure of Berlioz's Benvenuto Cellini. Another target of Benvenuto Cellini was the 'casual tone $[\ldots]$ and burlesque touches' of the libretto. ${ }^{117}$ Berlioz himself recognised that in order for the public to

\footnotetext{
116 David Cairns, Servitude and Greatness, p. 162.

117 Ibid., p. 164.
} 
understand Benvenuto Cellini the opera needed to be heard many times over, however several forces combined to ensure the work was only performed four times in its entirety in 1838, Act I performed three times in the following year, and after which the opera was shelved completely. ${ }^{118}$ This was not good news for the composer. Indeed the opera was quickly dubbed 'Malvenuto Cellini' in the press, (see Fig. 2) and this foray into opera certainly did not yield the success that Berlioz had longed for.

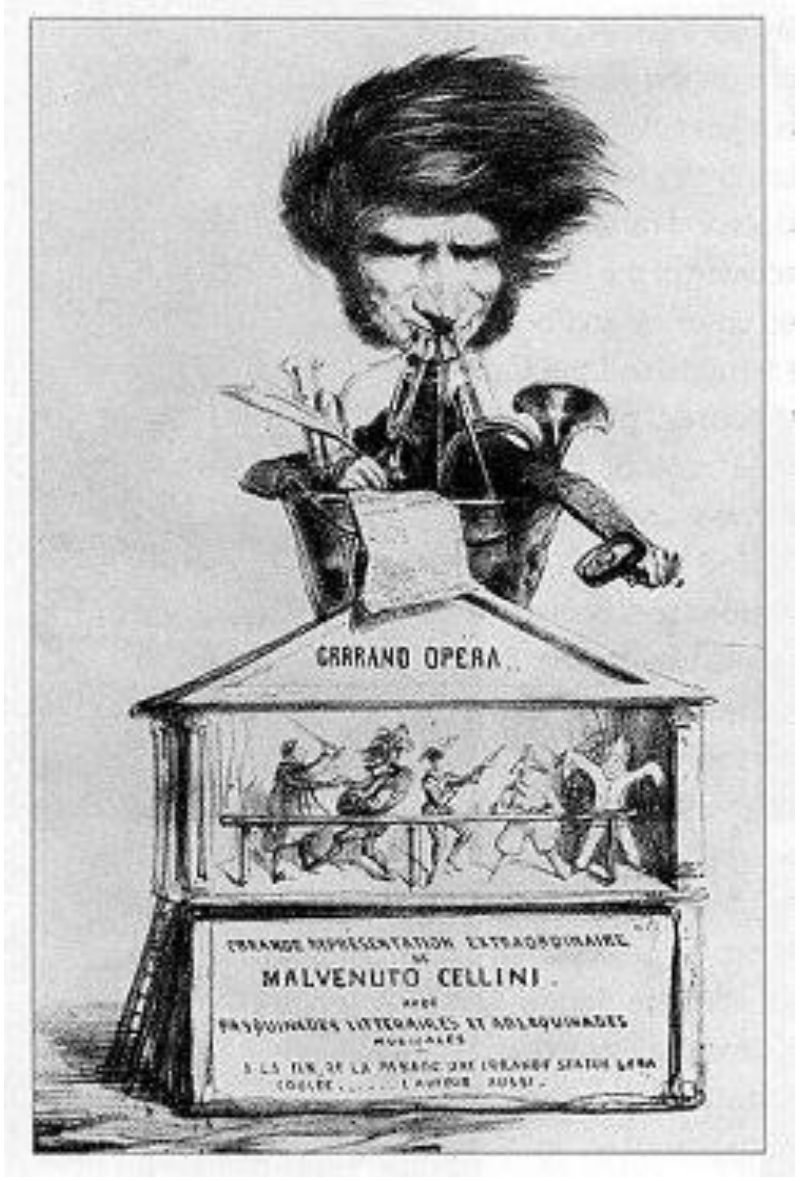

Figure 2: 'L'homme orchestre', lithograph by Benjamin Roubaud.

\footnotetext{
118 Holoman, Berlioz, p. 194.
} 


\section{IT'S A SYMPHONY FOLKS, BUT NOT AS YOU KNOW IT: STRUCTURE AND FORM IN ROMÉO ET JULIETTE}

While Roméo et Juliette is firmly labelled as a 'dramatic symphony' by

Berlioz, operatic and choral approaches are abundantly present throughout the score. Berlioz is perhaps pouring into his symphonies creative ideas and desires that could not be fulfilled through opera. Certainly within the context of mid nineteenth-century France, that Berlioz should turn towards the symphony and create an unusual sevenmovement work, complete with full choral forces and soloists, should not be altogether surprising. As D. Kern Holoman states, Berlioz's 'own culture favoured the lyric stage above all else, with religious music and military music ranking next in taste and experience'. ${ }^{119}$ As a consequence, such a highly prized musical form as opera was rigorously hemmed in by rules and regulations. Precisely because opera in France was ruled by convention, the symphony, as Berlioz re-imagined it, proved to be the natural home of the unconventional, where dramatic and musical values could roam free. While the symphony was not necessarily fashionable in France, Berlioz was not without symphonic models, and his ardent admiration of Beethoven's symphonies is well documented in his essays devoted to the subject. However, while Beethoven's Ninth Symphony may provide a precedent in terms of combining choral and orchestral forces, Berlioz does not follow Beethoven and his Viennese successors in terms of the prime importance of motivic development and the architectural concerns of traditional symphonic forms. Berlioz instead belies the dominance of the vocal forms and approaches prevalent in his own surroundings. As we will discover, his symphonic music has a tendency towards strophic forms and the evocation of dramatic episodes.

\footnotetext{
${ }^{119}$ Holoman. D. Kern 'Berlioz' in The Nineteenth-Century Symphony edited by D. Kern Holoman, (New York: Schirmer Books) 1997, p 108.
} 
Again as Holoman explains, Berlioz's symphonic 'palette' was comprised of 'words, feelings, and orchestral sound... it was the search for the right mix of these elements, and not the integrity of genre itself, that occupied his intellect. ${ }^{120}$

The dramatic symphony Berlioz completed in 1839 comprises seven different sections. Part I, consisting of an Introduction, Prologue, Strophes and Scherzetto, sets the scene and describes all of the action that is to follow. The orchestral introduction is easy to follow dramatically and just in case the audience had any doubts as to its subject, Berlioz has given it the subtitle of 'Combats - Tumulte - Intervention du Prince'. As an immediate signifier to his audience that they are in for a wild ride, Berlioz has set this first 'scene' as a fugue. Daniel Albright points out that a 'stiff, formal' fugue traditionally represents all that is orderly and controlled, yet this fugue instead expresses conflict, disorder and strife. ${ }^{121}$ One can easily identify the warring factions of the Capulets and Montagues represented by the busy string writing that interrupts, cuts off and restates the first motif over and over - it is as if each string section is asserting its own opinion and point of view, trying to drown out any opposition. (Ex. 2.1)

\footnotetext{
${ }^{120}$ Holoman 109

121 Albright, Berlioz's Semi-Operas: Roméo et Juliet and La damnation de Faust, p51. I would argue that we should take Albright's observation a step further. Berlioz is not only confronting his audiences expectations in regards to the function (and entertainment value) of a fugue but is also using what is essentially an instrumental, absolute technique to embody a dramatic and programmatic moment. As such, from the orchestra's first murmurings of discontent, Berlioz emphatically sets forth a particular approach to conveying narrative within purely instrumental forms that will find the most dramatic climaxes of our story told from the orchestra alone.
} 

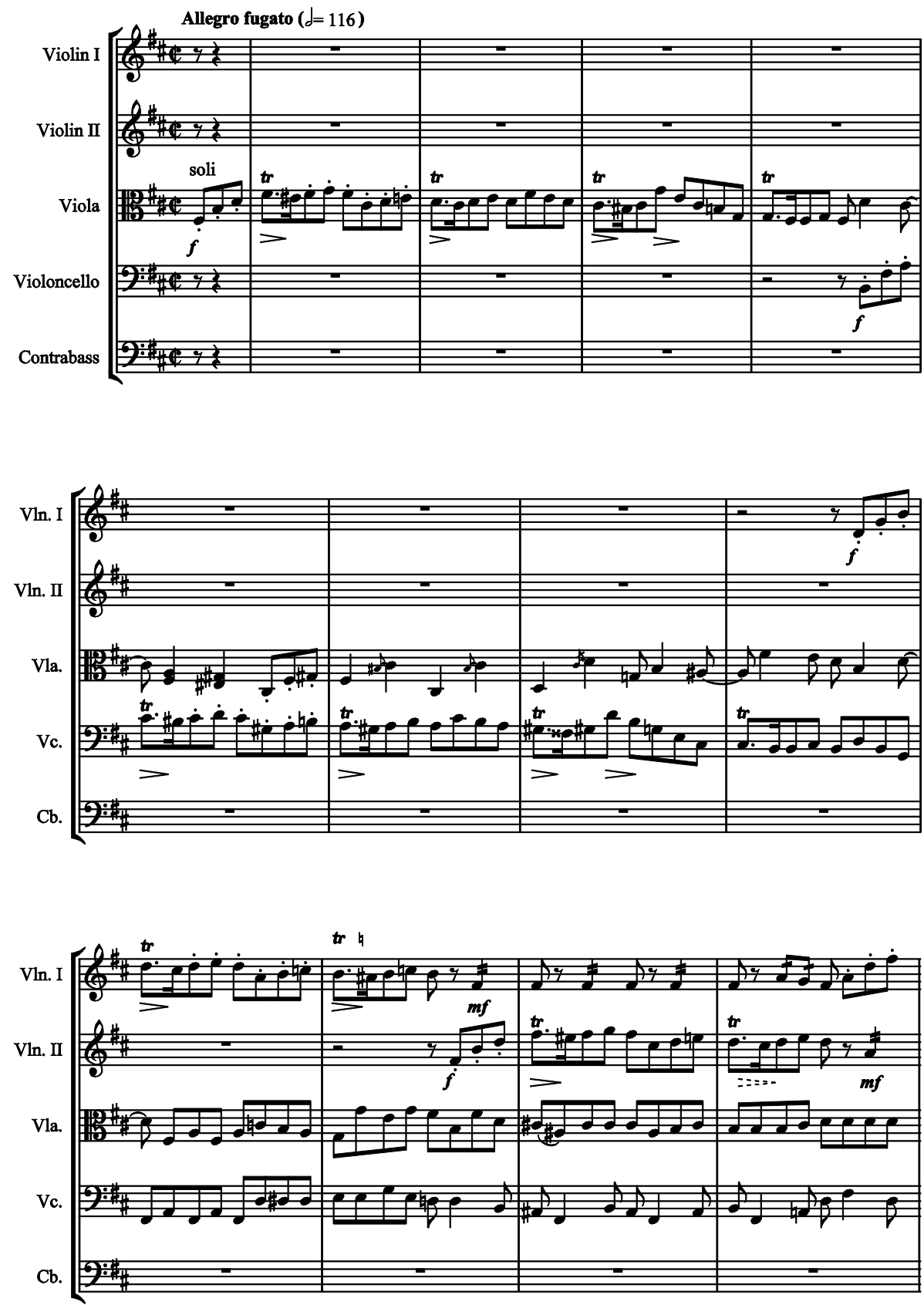

Example 2.1 Roméo et Juliette, 'Introduction' bars 1 - 13.

The trombone entry at bar 65, interrupting the busy and assertive motif and suppressing its reiteration, clearly depicts the character of the Prince. The noble and ominous nature of this brass sound is distinctly out of temper with the strings' constant 
fighting. (Ex. 2.2) Already within this introduction we can hear the energetic battle between these two houses coursing through the music and perhaps turning this music into an opera of our mind's eye.

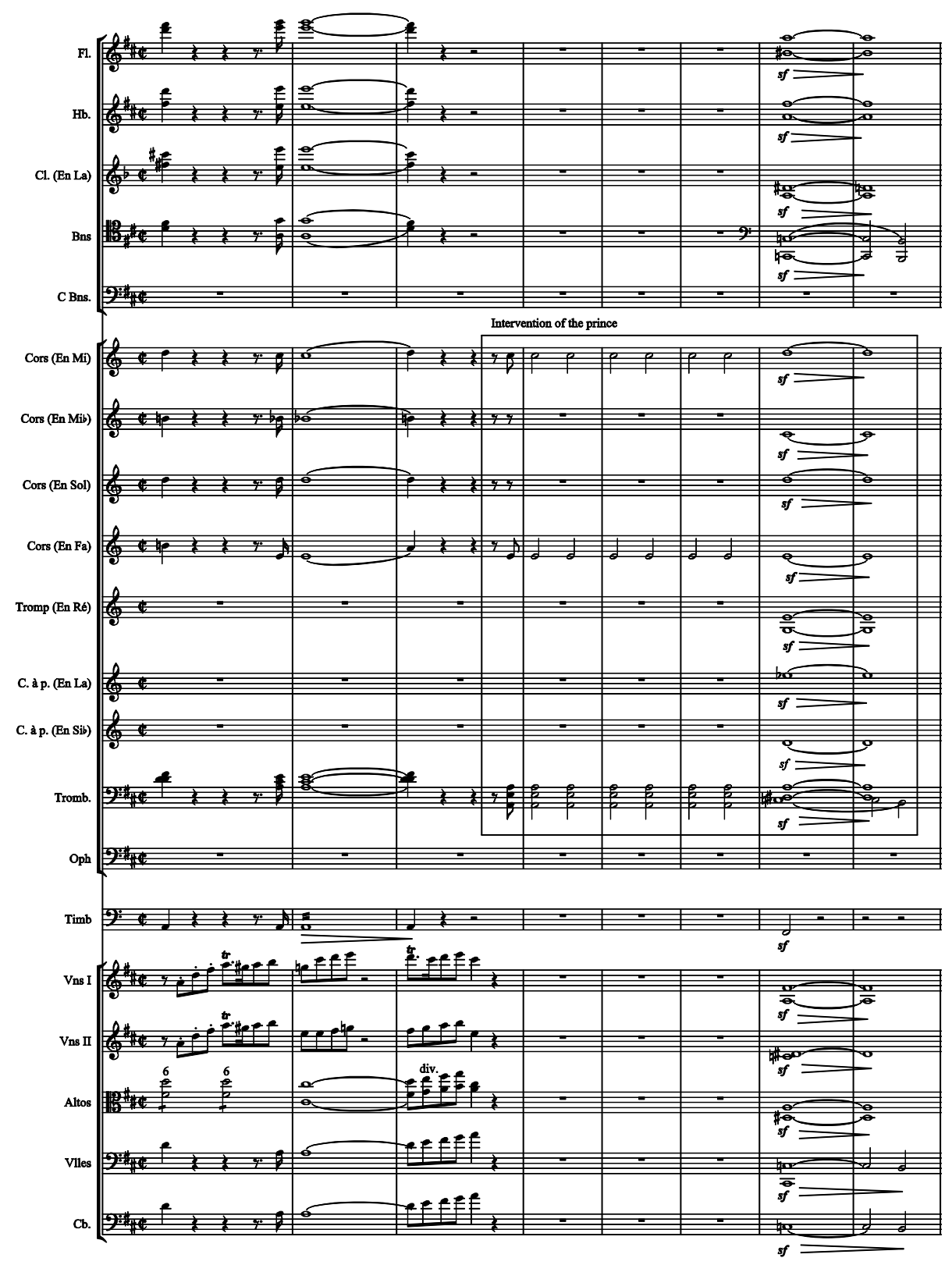

Example 2.2 Roméo et Juliette, 'Introduction' bars $63-70$.

Though relatively short, this introduction is very much within the tradition of an operatic overture, setting the scene of the 
drama that is to follow. Indeed in this movement we can see Berlioz's ideal overture. Berlioz was famously passionate about the operas of Gluck in which he found the almost perfect expressions of nobility, of grief, of true and honest emotions. Despite this, Berlioz had very different theories about what dramatic music was capable of achieving. Berlioz credits Gluck with the notion that in an opera the sole purpose of music is to add to poetry what colour adds to drawing. ${ }^{122}$ Berlioz disagrees with this analogy and feels that the composer must create both the line and the colour of a work - the text simply provides the subject. Furthermore, in instrumental music such as the overture, it is all the more important that music should provide both line and colour. However, in order for the overture to 'indicate the subject' of the drama, as both Gluck and Berlioz thought necessary, 'music must necessarily resort to words, whether sung, recited, or simply read, to fill in the gap left by the expressive powers in works that aim simultaneously at the mind and the imagination. ${ }^{123}$ Thus, in Berlioz's Introduction we have music that clearly indicates the subject of this drama, not only through the line and colour of the music, but also through the specific guidance of Berlioz's subtitles.

The prologue then follows. We hear only from the 'petit chœur' who first tell us that 'D'anciennes haines endormies /Ont surgi, comme l'enfer; /Capulets, Montagus, deux maisons ennemies /Dans Vérone ont croisé le fer.' ['Ancient slumbering hates /Have risen up as if from hell. /Capulets, Montagues, two

\footnotetext{
${ }^{122}$ Hector Berlioz, The Art of Music and Other Essays (A travers chants) trans. Elizabeth Csicsery-Rónay, (Bloomington, Indianapolis: Indiana University Press, 1994), p. 102.

123 Ibid., p. 103.
} 
enemy clans, / Have crossed blades in Verona.'] ${ }^{124}$ The Prince has suppressed all violence, and in this time of peace the Capulets are to give a ball. The chorus, acting as narrator, introduces the young Montague Romeo, in love with Juliet, and bemoaning his cruel fate. This chorus goes on to describe how 'Le bruit des instruments, les chants mélodieux / Partent des salons où l'or brille, /Excitant et la danse et les éclats joyeux.' ['The sound of instruments, the pleasant singing / Wafts out of the salons where gold gleams, / Animating the dancing and the festivity.'] ${ }^{125}$ Berlioz then cites the musical material of the ball scene, which the audience will hear again in the second movement. This short citation lasts only twenty bars before we are told that the ball has finished, just as, literally, the music of the ball finishes. The chorus continues describing Romeo's feelings and actions. He sighs at the thought of leaving Juliet's presence. He gains courage, jumps the fence and is at last under her balcony, declaring his ardent, burning love for her! We hear musical motives that recur in the second and third purely instrumental parts. Music from bars 69 to 76 in the prologue, 'Hélas! Roméo soupire', is restated in Part II in bars 24 to 31. (Ex 2.3. and Ex. 2.4) Music from bars 91 to 95 in the prologue, 'Se découvre à Juliette, Et de son cœur les feux éclatent à leur tour', is heard again in Part III in bars 367 to 371. (Ex. 2.5 and Ex. 2.6) Revealing important themes to the audience in the prologue, accompanied with vocal explanations of their meaning, Berlioz is guiding our understanding of the meaning and dramatic subjects of the purely instrumental movements that follow.

${ }^{124}$ Berlioz, Roméo et Juliette NBE, pp 29-30. Translated by Julian Rushton. All subsequent translations of text from this score are by Julian Rushton.

125 Ibid., pp. 31-32. 

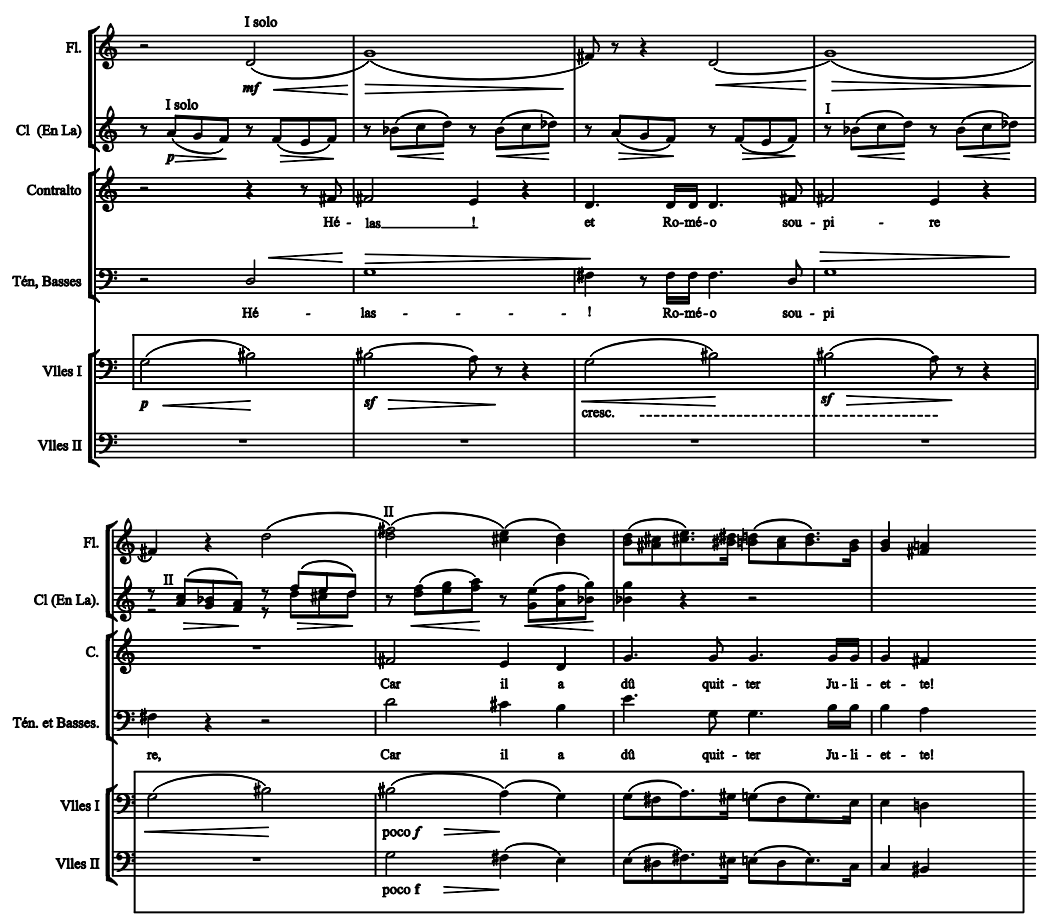

Example 2.3 Roméo et Juliette, Prologue, bars 69-76.
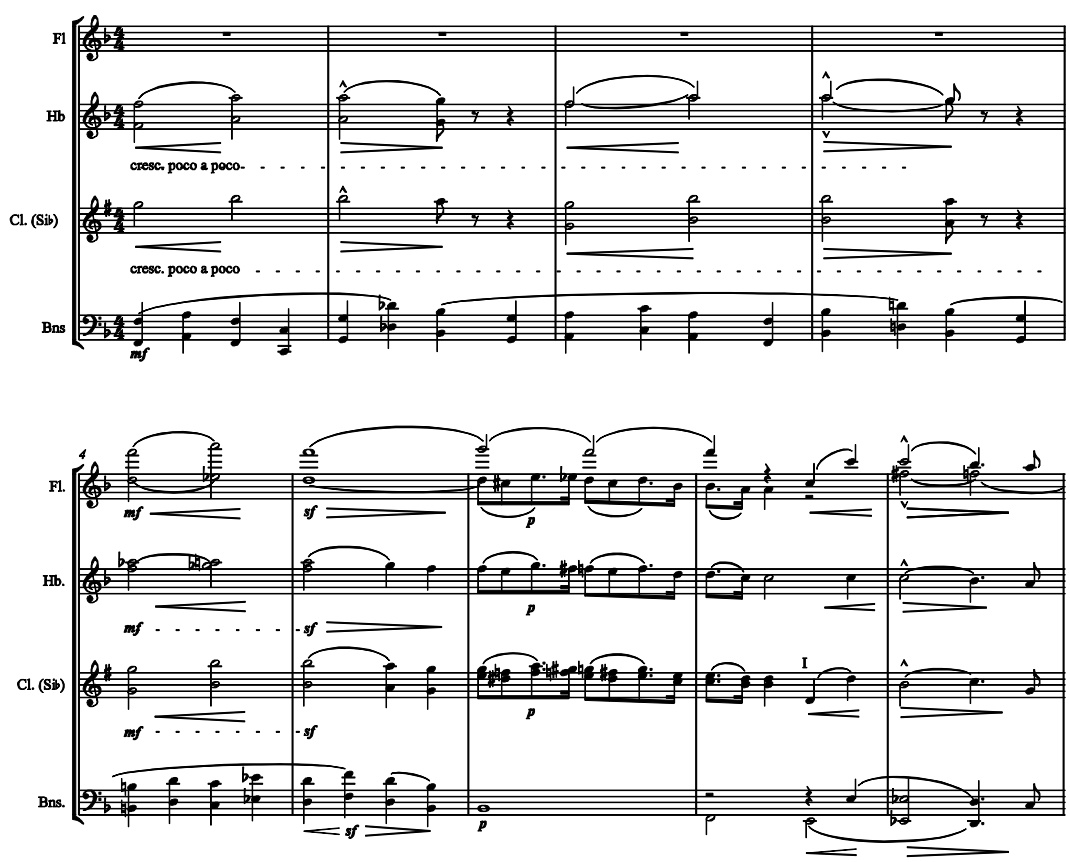

Example 2.4 Roméo et Juliette. Part II, bars 24-31. 


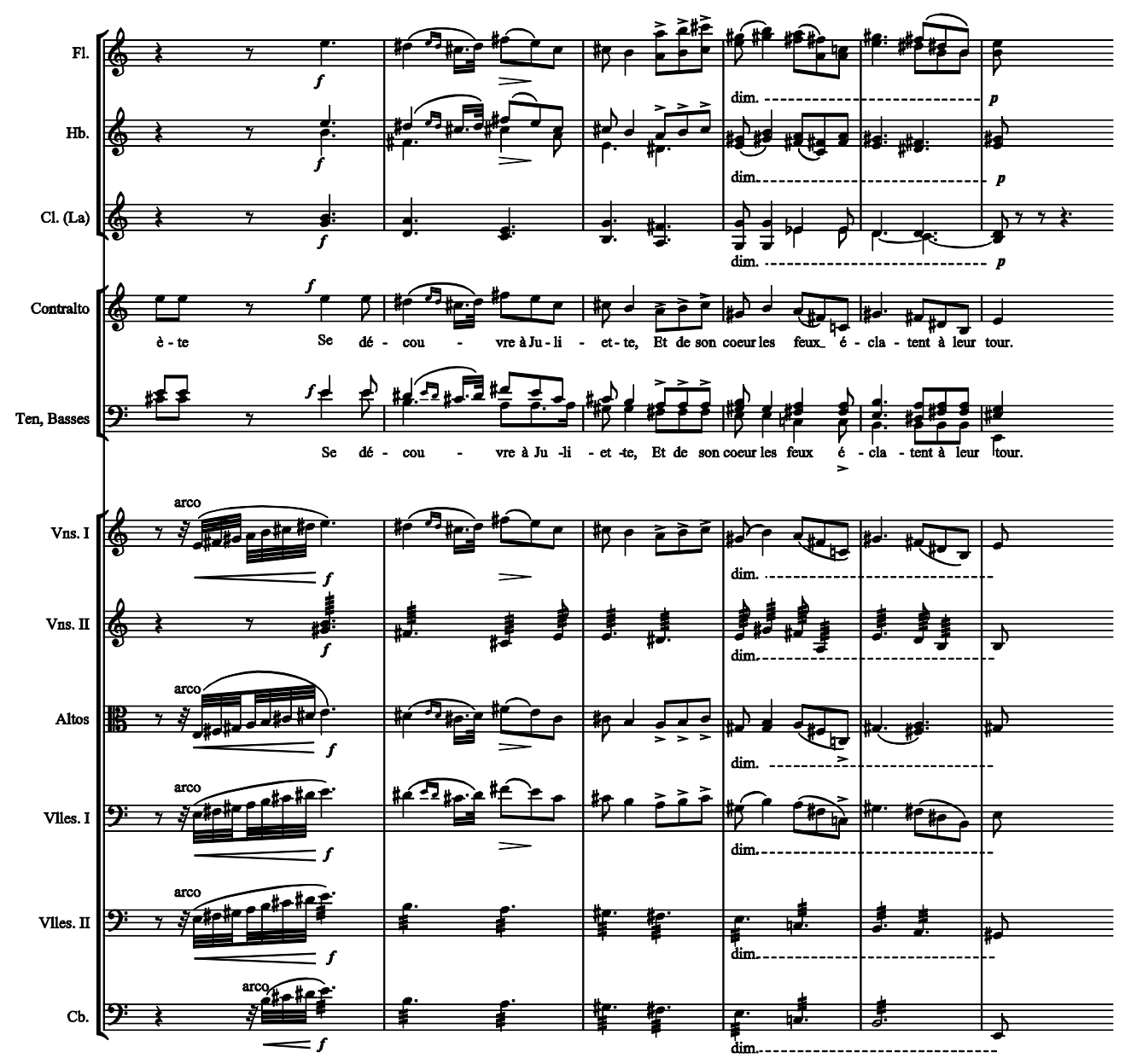

Example 2.5 Roméo et Juliette, Prologue, bars 91-95. 

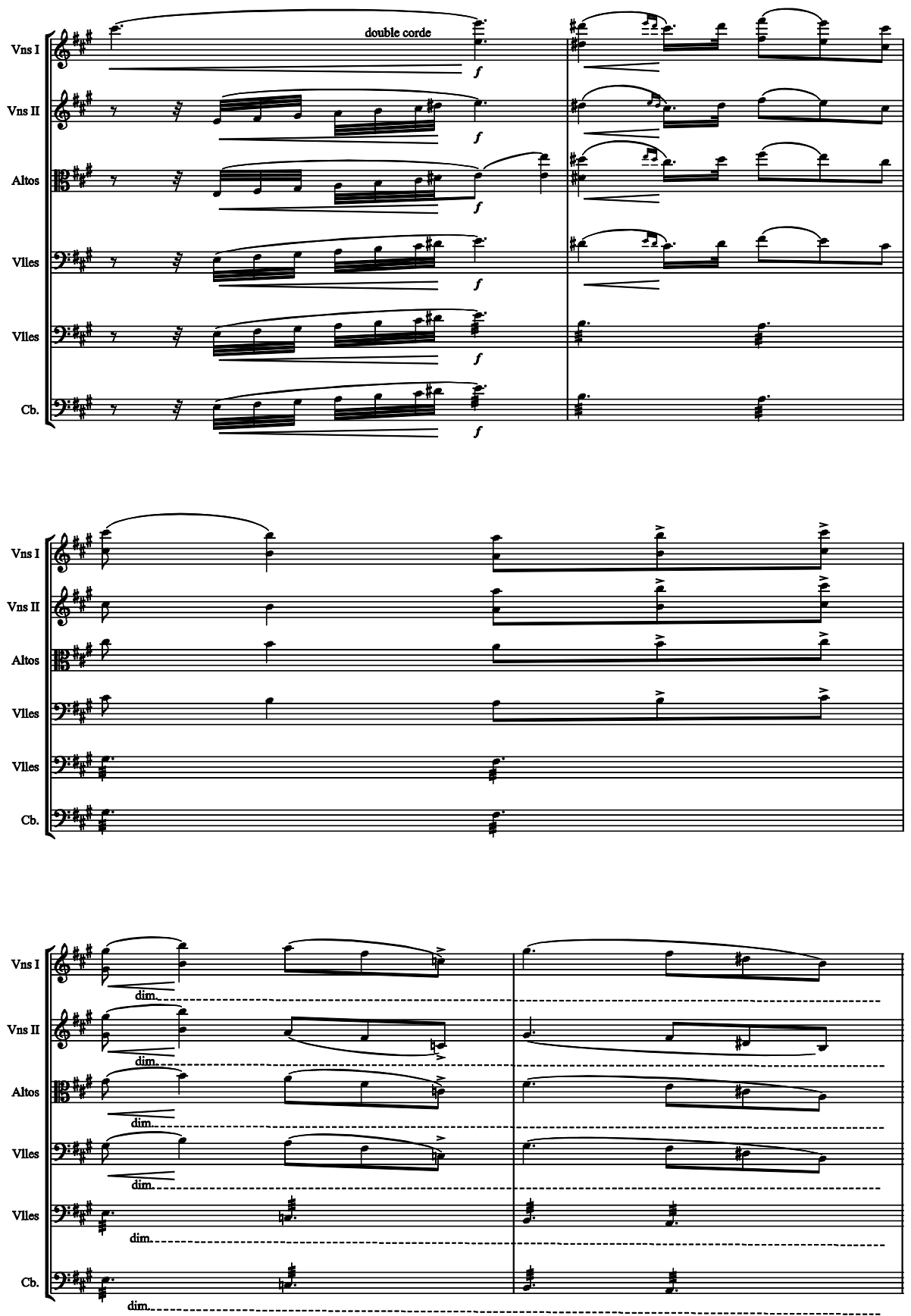

Example 2.6 Roméo et Juliette, Part III bars 367-371.

In the first version of this symphony Berlioz had as a conclusion to his prologue an explanation for his audience of the inclusion of the subsequent three instrumental movements. 
The original text reiterates how it is these first images and scenes, just described, that the orchestra will now translate into music. ${ }^{126}$ Instead in the final revision of the work made in 1858, Berlioz decided to exclude the second prologue and re-wrote the end of his first and now only prologue to narrate the rest of the story. This change removed any preparation of the audience for the fact that the following three movements were scored for orchestra alone. Instead the chorus now describes the rest of this drama for the audience: 'Bientôt la mort est souveraine: Capulets, Montagus, domptés par les douleurs, /Se rapprochent enfin pour abjurer la haine / Qui fit verser tant sang et des pleurs' ['Soon death rules our scene. /Capulets and Montagues, subdued by sorrow, /Agree at last to renounce the hatred /Which has shed so much blood and tears'. ${ }^{127}$ Thus the vocal prologue narrates the entire synopsis of the music that is to follow. As Rushton states quite simply, 'Berlioz's Prologue has two aims: to sing, in effect, the programme of the symphony, and to introduce some of its themes. ${ }^{, 128}$ Why did Berlioz feel the need to explicitly relate his programme to the audience in this manner? As Albright argues:

The Prologue is turning into a thematic catalogue, for Roméo et Juliette is a symphony that incorporates its own playbill. Berlioz is instructing us how to interpret the purely instrumental music to come [...] This is how Berlioz avoids what might be called the Gluck problem: the inability of an overture to confess much about the drama to come. ${ }^{129}$

\footnotetext{
126 'Tels son d'abord, tels sont les tableaux et les scènes /Que devant vous, cherchant des routes incertaines, /L'orchestre va tenter de traduire en accords'. Berlioz, Roméo et Juliette NBE, pp 407.

${ }^{127}$ Berlioz, Roméo et Juliette NBE, pp. 56-57.

${ }^{128}$ Rushton, Berlioz, Roméo et Juliette, p. 23.
} 
It seems an interesting paradox that though this opening music functions in part as an operatic overture, setting forth important thematic material, its structure and function is predominantly non-operatic primarily because the music that follows is symphonic and without voice and text. Berlioz is making allusions to operatic forms within a distinctly non-operatic composition.

Following the Prologue with its first statements of salient musical themes, Berlioz then changes the texture of Part I considerably. What follows on from this section can almost be seen as the composer's own statement of intent. We no longer are being told what will happen in the story but instead listen to some strophes from the solo contralto. These are an exploration of the beauty of Shakespeare's writing in itself and the way in which the intensity and fervour of first love is, in fact, inimitable. The contralto declares: 'Quel art, dans sa langue choisie, /Rendrait vos célestes appas? [...] n'êtes-vous pas / Plus haut que toute poésie?’ ['What art, in its chosen language, /Can do justice to your heavenly beauty? [...] Are you not higher than poetry?'] ${ }^{130}$ The contralto goes on to state that none but Shakespeare knew how to recreate the magic of innocent love, and that he has taken that talent with him to the heavens. Berlioz has thus expressed why this dramatic composition is embodied within a symphony rather than a form for the operatic stage. For Berlioz, Shakespeare has already achieved all that poetry can achieve, why try and re-create that? Instead Berlioz will write instrumental pieces that, through music, can touch upon the void so illuminated in Shakespeare's play. Indeed when Berlioz justified himself as to why his two protagonists

\footnotetext{
${ }^{129}$ Albright, Berlioz's Semi-Operas: Roméo et Juliette and La damnation de Faust, p. 52.

${ }^{130}$ Berlioz, Roméo et Juliette NBE, pp. 39-40
} 
never appear vocally, he declared that (too) many 'vocal duets of love and despair' had already been composed, and it was 'wise as well as unusual to attempt another means of expression. It is also because the very sublimity of this love made its depiction so dangerous for the musician that he had to give his imagination a latitude that the positive sense of the sung words would not have given him, resorting instead to instrumental language, which was richer, more varied, less precise, and by its very indefiniteness incomparably more powerful in such a case. ${ }^{131}$ In the text of these strophes we learn that Berlioz hopes not to re-tell the story of these star-crossed lovers but to comment upon his own experience of seeing this play, and to try and communicate the inexpressible effect of these scenes. In some sense we can see this work as not only a love story between Romeo and Juliet but also between Shakespeare and Berlioz. However, while the text seems to state one thing, its title and form alludes to another. As Langford explains, the term 'Strophes' is a label that describes the form of an aria, but specifically an old-fashioned aria form that gradually shifted from the domain of opéra-comique to more 'serious opera'. ${ }^{132}$ Alongside this, the texture and instrumentation of these strophes, with the use of obbligato instruments accompanying the harp and voice, is reminiscent of many aria accompaniments including Isabel's cavatine from Meyerbeer's Robert le diable, an opera that was wildly popular throughout Berlioz's lifetime. ${ }^{133}$ I would add however that while the accompaniment may remind one of Robert le diable, Berlioz's strophes do not conform to other important operatic traditions. The contralto's music has a very limited range, with music that lays between middle $\mathrm{c}$ and

\footnotetext{
131 These comments were printed in an Avant-propos published in the libretto for Berlioz's 1839 performance and reprinted in the vocal score of 1858. A translation of this can be found in the first appendix of Berlioz, Roméo et Juliette NBE.

${ }^{132}$ Langford, "The "Dramatic Symphonies" of Berlioz as an Outgrowth of the French Operatic Tradition', 95.

${ }^{133}$ Langford, "The "Dramatic Symphonies" of Berlioz as an Outgrowth of the French Operatic Tradition', 95.
} 
the $\mathrm{f}$ an octave above. What's more, the contraltos line is mostly very static. Throughout verses, phrases are generally comprised of repeated notes. On a macro level, the strophes themselves are repeated without much variation or ornamentation. While this gives the narrator an emphatic sense of authority it is nowhere near the flashy turns and trills of Isabel's soprano cavatine. Berlioz comments upon the limitations of opera whilst using its traditions. This reliance on the conventions of opera while subverting them is purposeful. While recognising the operatic forms embedded within this work, we then begin to imagine and listen as if we were indeed at the opera or theatre, seeing the inexpressible being performed before our very ears. Berlioz tries to create the best of both worlds, relying on a habit of listening to music that traditionally is associated with exceptional and extravagant visual scenery, while also creating a sense of the unknown and inexpressible.

After the Strophes, though still within Part I, we hear a scherzetto with the chorus describing the exploits of Queen Mab. Again this moment foreshadows music to come: the Scherzo of Part IV. Both this scherzetto and the larger scherzo are in $\mathrm{F}$ major, both have similar textures and contrasts between the high woodwind instruments and bass string instruments. However, Berlioz does not actually use similar motivic material as he does with the foreshadowing of themes for the two preceding movements. Julian Rushton suggests that Berlioz was trying to avoid 'redundancy'. ${ }^{134}$ This difference would make dramatic sense also, as the drama of Queen Mab lies in her inventive and original flights of fancy and the unexpected turns she takes. While we may capture some fragment of her in Part I

134 Rushton, Berlioz, Roméo et Juliette, p. 26. 
it is only appropriate that that utterance should have changed or shifted when we experience her again in Part IV.

The following three movements are almost entirely without text. Aside from some faint off- stage singing there is no sung text; instead each Part has descriptive subtitles. Part II is labelled 'Roméo seul - Tristesse - Bruit lointain de bal et de concert Grande Fête chez Capulet'. As already stated above, the music of Romeo sighing and the ball music returns in this movement, this time unaccompanied by vocal explanations. The fact that the ball scene is without text is not immediately outside of operatic tradition, as this easily mirrors the place of ballet within grand opera. Part III, which we will consider in more depth below, is labelled 'Nuit sereine - Le jardin de Capulet, silencieux et désert - Scène d'amour'. Part IV is the scherzo 'La Reine Mab, ou la Fée des Songes'. It is these three movements that are often, in modern concert practice, extracted and performed as a suite, independent of the dramatic symphony as a whole.

While thus far the relationships between this symphony and grand opera seem to be easily identifiable, Part III, specifically the 'Scène d'amour', is arguably the most ambiguous section not only of this score, but of Berlioz's entire compositional output. ${ }^{135}$ This movement recalls musical motives from the opening prologue. It opens with a double chorus of Capulets, singing from backstage about what a fantastic night they have just had: what a ball, what silly chatter, and what ladies! The chorus eventually fades away and we are left with the orchestra

135 Rodgers, Form, Program, and Metaphor in the Music of Berlioz, p. 107. 
evoking the love scene between Romeo and his Juliet. The most commented upon feature of this movement is of course the famous (A-major) 'love theme'. This theme takes the easily recognisable themes associated with Romeo and Juliet and combines them to create a third 'love' theme. It is easy to superimpose the dialogue between the two lovers onto the musical relationship between these two themes as Ian Kemp has done. ${ }^{136}$ Vera Micznik on the other hand finds such analyses limiting, stating that the music would be equally involving and moving regardless of the programme. ${ }^{137}$ Certainly we must remember that Berlioz has eschewed the love duets of countless couples gone before and instead created something entirely his own and something that indeed he had never done before, arguably something that is far more than an operatic duet for instruments. As Rodgers states:

This is, however, a combination unlike any other in Berlioz - not the superimposition of two opening ideas, as one finds in the Songe d'une nuit du sabbat from the Symphonie fantastique or in Roméo seul, not a dialectic synthesis of opposing elements, but the gradual melding of two similar ideas into one another, or, really, the metamorphosis of a first idea into a second idea, and then a first and second idea into a third. B and C, after all, are as related to each other as they are to D (see [Ex. 6.3 and] Ex. 6.4). ${ }^{138}$

${ }^{136}$ Ian Kemp has gone so far as to match musical phrases with specific lines from Shakespeare's play see Ian Kemp, "Romeo and Juliet and Roméo et Juliette," in Berlioz. Studies ed. Peter Bloom (Cambridge University Press, 2000), pp. 6468.

137 Vera Micznik, 'Of Ways of Telling: Intertextuality and Historical Evidence in Berlioz's Roméo et Juliette', $19^{\text {th }}$-Century Music 24/1 (2000), 22-3 and 39-40.

138 Rodgers, Form, Program, and Metaphor in the Music of Berlioz, p. 117. 
B ("Romeo's" theme)

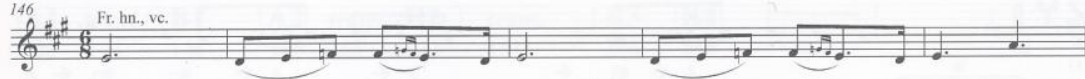

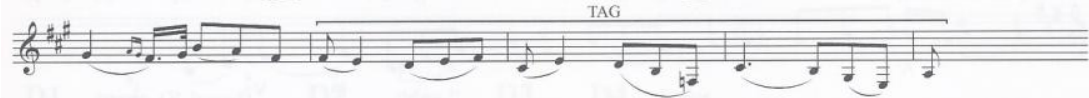

C ("Juliet's" theme)

(fl, vng. hn.

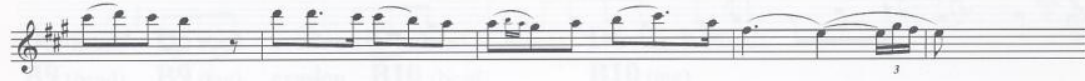

D (the "love theme")

(6)

Ex. 6.3 Scène d'amour, main themes
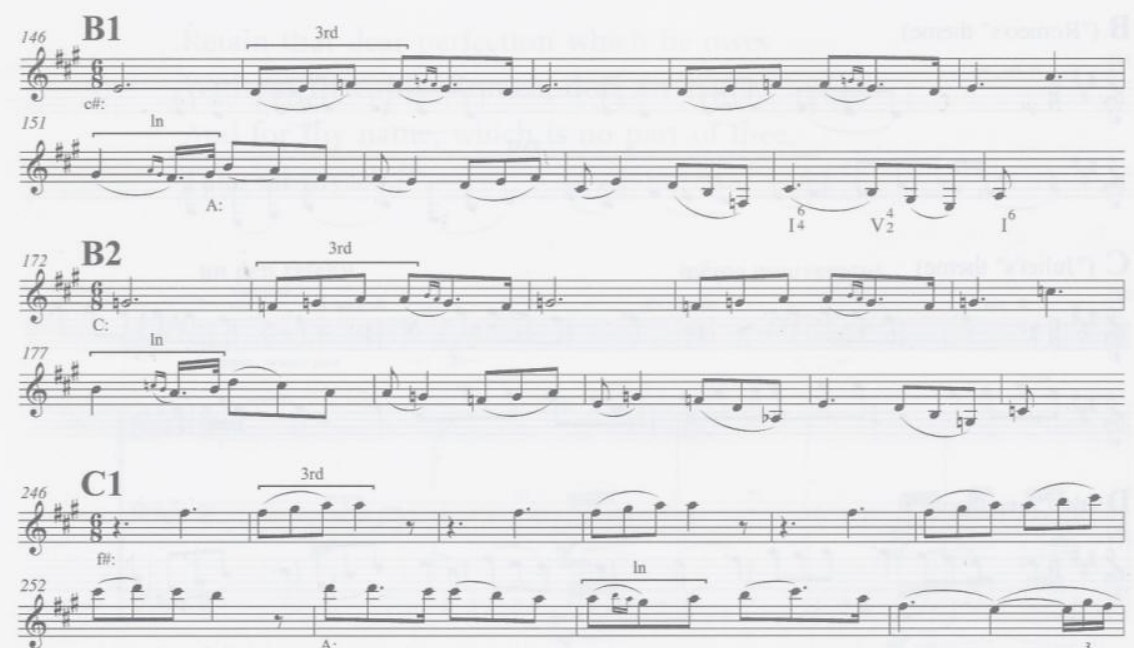

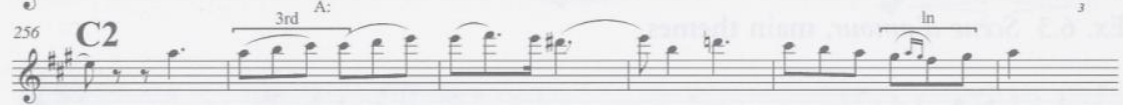
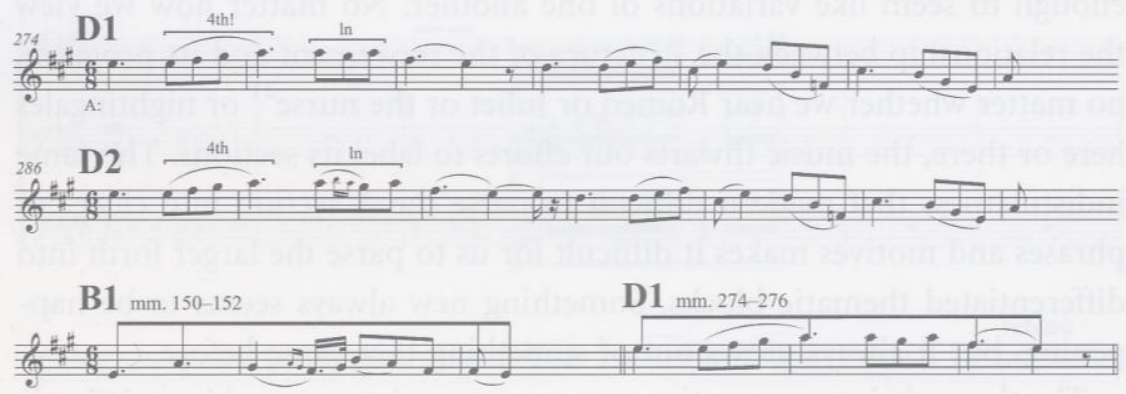

Ex. 6.4 Thematic relationships 
Rodgers praises this technique of music acting as an aural metaphor, recreating the emotions and actions of Shakespeare's text, or as Micznik would contest, acting as a metaphor for any love scene. Yet perhaps this movement is very specific to Romeo and Juliet. With Rodgers' analysis in mind we can begin to see how this entire movement is narrated from Romeo's perspective. That the thematic material of Juliet is contrived from Romeo suggests she is his creation. Her music is a re-configuring of Romeo's music. Juliet's theme begins in a very similar fashion to Romeo's theme - a longer note followed by a group of three ascending quavers. This 'tag' is repeated twice, as if Romeo is unable to completely comprehend the musical vision in front of him. Suddenly her theme blossoms as triplets of quavers ascend further into the stratosphere. Rather than including new musical material, Romeo is taking a musical idea and simply repeating it. Interestingly all of Juliet's rhythms are also directly derived from the rhythms of Romeo's theme - the grouping of quavers, the grace note figures etc. Indeed the only point of difference is one of gender - Juliet's theme sounds an octave above Romeo's. It is thus clear that Juliet's theme is created from the same musical material of Romeo's theme and the possible narrative meanings of this deserves closer inspection. If Juliet's music only exists as an extension of Romeo's music, if she only appears through the musical eyes of Romeo, it becomes apparent that it is from Romeo's perspective in which we experience the unfolding events. To some degree, this is not akin to a duet at all but a self-reflecting aria delivered from the composer. Considering Berlioz's obsession with Harriet Smithson, springing forth from first seeing her as Ophelia and Juliet, it would be understandable that Berlioz shared an affinity with Romeo. If we can accept that the composer perhaps positioned himself to assume Romeo's perspective, this scene reflects not only this love scene, but also the ardent passions affected upon Berlioz as he witnessed these life changing scenes at the Odéon. 
Part V, 'Convoi funèbre de Juliette', changes the mood dramatically. It was between the fourth and fifth parts that Berlioz had originally placed his second prologue. This second prologue, given the same function as the first, was to explain the ensuing drama. There was to be 'No more dancing, now - no more /love scenes!' However, the fugal funeral march of this fifth movement needs little explanation. The voices of the Capulets return, first chanting on a unison E before a more lyrical fugue for voices commences. They mourn the death of their virginal daughter, (though she is neither dead nor virginal...). Again the choice of a fugue at this moment has a strong programmatic function. The same musical form that expressed the conflict between families is now used to express how death and tragedy will unite them.

Part VI, 'Roméo au tombeau des Capulets - Invocation' is a return to a pure orchestral texture. This is another controversial movement in the work and has been exhaustively commented on for its incredibly literal musical evocation of the events that unfold in this movement. We hear Romeo, distraught, enter the Capulet's tomb (Ex. 2.5); we hear Romeo take his poison and Juliet awake (Ex. 2.6); we hear Romeo, briefly forgetting the fact he has just drunk poison, overcome with joy (Ex. 2.7); we hear the moment when the poison grips his body (2.8); we hear Juliet, in despair, take her own life (Ex. 2.9). These moments are clearly articulated in the music of this descriptive movement. As this movement dies away, confused voices burst forth as again, Berlioz changes gear and uses his entire vocal and orchestra forces for the final Part VII. Julian Rushton has labelled this 
final movement the most overtly operatic in this symphony. ${ }^{139}$

The finale carries the titles of 'Final - Air - Serment' with subtitles 'La foule accourt au cimetière - Rixe des Capulets et des Montagus - Récitatif et Air du Père Laurence - Serment de réconciliation'. The choruses of Montagues and Capulets discover the bodies of their children; they blame each other and begin quarrelling before the final explanation comes from Friar Lawrence. It is the Friar who in an aria chastises the two families and declares that through God's law they must make peace and so the work ends.

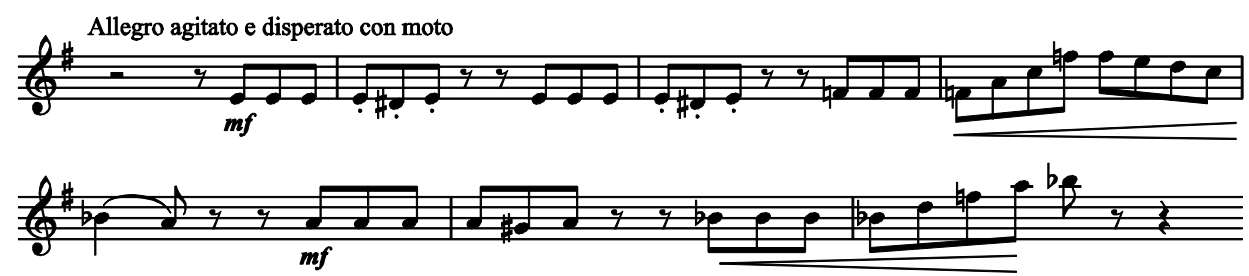

Ex. 2.5. 'Roméo au tombeau des Capulets', bars 1-7. Romeo bursting into Juliet's Tomb.

139 Rushton, Berlioz, Roméo et Juliette, p. 56. 

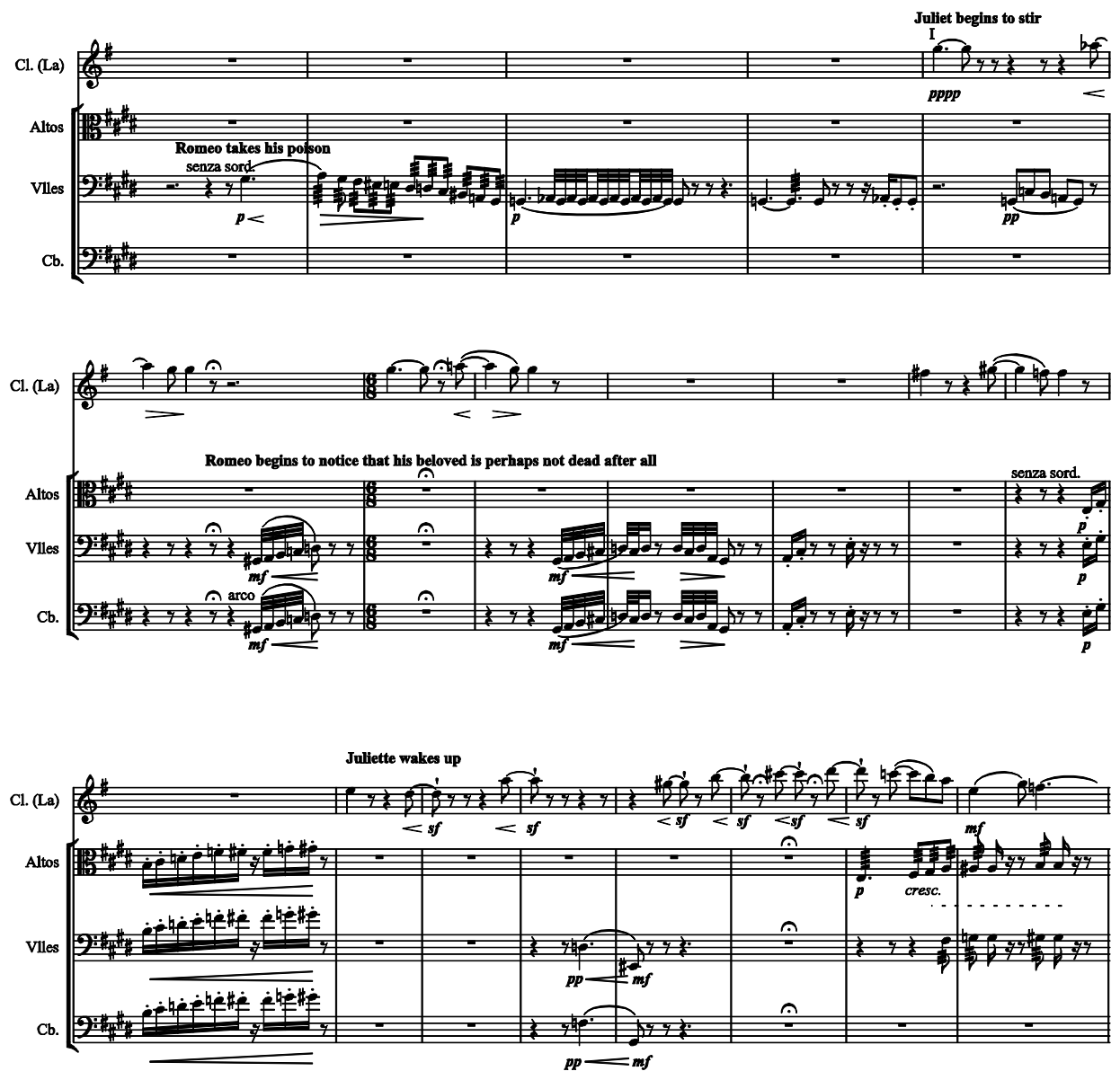

Example 2.6. 'Roméo au tombeau des Capulets', bars 70-89. 


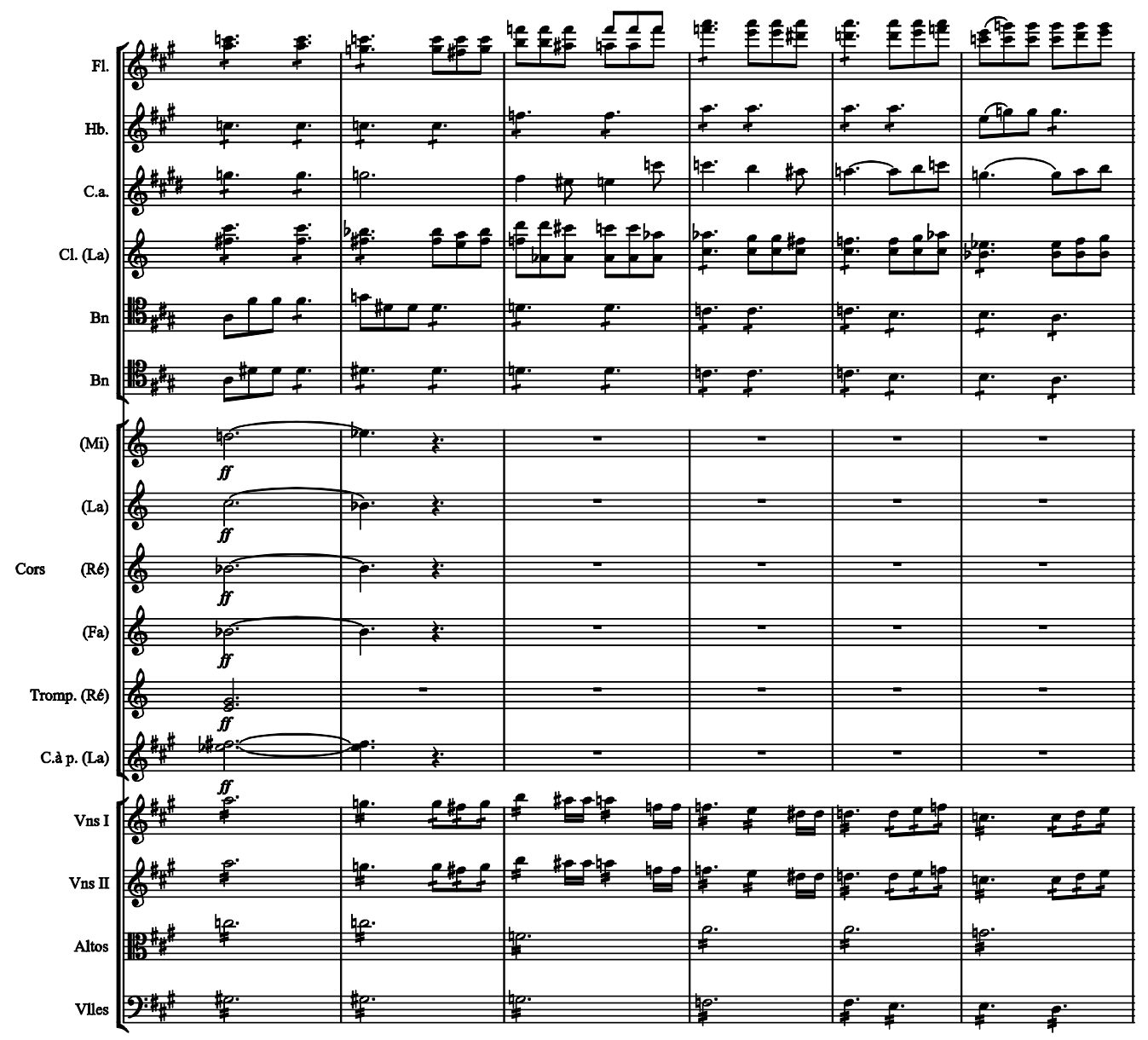

Example 2.7 'Roméo au tombeau des Capulets’, bars 113-118.

Romeo so delirious with joy the love theme returns.

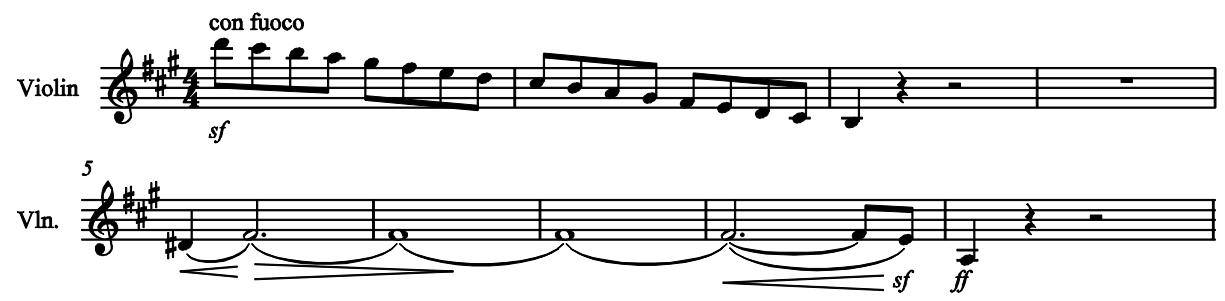

Example 2.8 'Roméo au tombeau des Capulets', bars 202-210,

Romeo's death. 

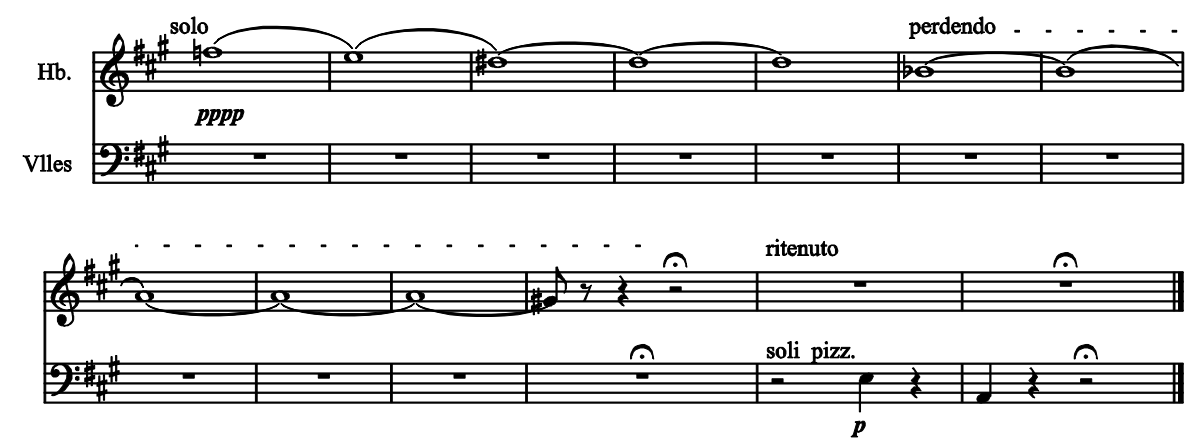

Example 2.9 Roméo au tombeau des Capulets' bars 215-227, Juliet's death.

THAT NIGHT AT THE THEATRE - RECREATING WITHIN HIS MUSIC THE ROMEO AND JULIET BERLIOZ SAW

With some sense of the macro structure of Roméo et Juliette, it is easy to understand why the performance of this work, both in Berlioz's time and in a modern context, presents audiences with many challenges. It is important to remember that this symphony does not narrate the entire drama of Romeo and Juliet. Roméo et Juliette effectively depicts a very fragmented version of the story. The fragmented and un-linear nature of this work and the scenes Berlioz chose to set musically do highlight, perhaps, some of the social and aesthetic ideas Berlioz was grappling with throughout his career. This symphony was never in fact supposed to be a musical drama of the story of Romeo and Juliet, but instead a musical drama of Berlioz's own personal experience of watching Shakespeare's Romeo and Juliet on that fateful night in Paris. Berlioz's own memory of only gaining brief glimpses of Shakespeare's poetry is precisely the experience he re-creates for his own audience. Indeed the structure of the narrative in this work also seems to indicate 
this, with a substantial portion of the symphony told from Romeo's/Berlioz's perspective. There are various moments in the work and in Berlioz's own documentation of the process of composition that point to the idea that what he wanted to achieve was not simply a musical retelling of the story but a musical retelling of his own experience of the play, of a theatrical experience. The compositional choices he made are firmly associated with the production he saw. It is precisely because he was so firmly entrenched in the production of 1827 that Berlioz re-composed this story in such a new and visually ambiguous form.

At this point we should return to re-examine Berlioz's first experience of Romeo and Juliet. Berlioz first saw the play in Paris in 1827 produced by a touring English company. The play was delivered in English with expensive modern scenery and a contemporary 'realistic' style of acting. ${ }^{140}$ As Berlioz reminds us:

I may add that at that time I did not know a word of English; I could only glimpse Shakespeare darkly through the mists of Letourner's translation; the splendour of the poetry which gives a whole new glowing dimension to his glorious works was lost on me.[...] But the power of the acting, especially that of Juliet herself, the rapid flow of scenes, the play of expression and voice and gesture, told me more and gave me a far richer awareness of the ideas and passions of the original than the words of my pale and garbled translation could do. ${ }^{141}$

While seemingly imbibing the play through gesture, tone and inflection alone, Berlioz saw a version of Shakespeare's play as

\footnotetext{
${ }^{140}$ Elliot, Jr., 'The Shakespeare Berlioz Saw', 294.

141 Berlioz, The Memoirs of Hector Berlioz, p. 73.
} 
'improved' by David Garrick and later William Abbott. ${ }^{142}$ These changes were seen as a way of making the rough and rude Shakespeare more appropriate for eighteenth- and nineteenthcentury tastes. Romeo could no longer be accused of being flighty if there was no Rosaline, and Juliet's more saucy puns were quickly removed. These, along with other changes, meant that our protagonists could at last become proper, admirable heroes appropriate to their late eighteenth- and nineteenthcentury audiences. ${ }^{143}$ It was Garrick who stipulated that Juliet should wake up before Romeo dies, Shakespeare having seemingly passed over what was soon considered a supreme dramatic moment. Thus in the version Berlioz saw, our two lovers are briefly reunited before they both die. Though we know that by 1839 Berlioz had read more 'authentic' translations of the play, it is precisely the death of the reunited lovers that Berlioz sets. ${ }^{144}$

It was William Abbott who decided to add a funeral procession to the 1827 production, complete with music. The addition of a musical ceremony was standard practice in many plays throughout the nineteenth century that contained death or other events associated with ritual, and of course this kind of ritual was also common in grand opera. Unsurprisingly then, this procession is also incorporated into Berlioz's version.

\footnotetext{
142 Elliott, Jr., 'The Shakespeare Berlioz Saw', 297.

143 Albright, Berlioz's Semi-Operas: Roméo et Juliette and La damnation de Faust, p. 32.

144 As Albright states, Berlioz had read Shakespeare in translation and 'haltingly' in its original English. Furthermore his decision to set the ending of Shakespeare's version rather than the more common ending immediately after Juliette's death is further evidence that he was familiar with Shakespeare's complete play. See Ibid., p. 45.
} 
Berlioz's most controversial example of recreating a theatrical event musically is his Part VI in Roméo et Juliette, 'Roméo au tombeau'. Berlioz relives this moment in the play:

When Juliette, coming back to life, feebly whispers the name Romeo, young Montague is struck dumb for a moment and stands transfixed. A second call, more tender this time, draws his attention to the bier. Juliet stirs, dispelling his doubt. She is alive! He leaps up to the funeral couch, snatches up the beloved body, tears away the veil and shroud, and carries it downstage, upright in his arms. Juliet looks around languidly, her eyes dull. Romeo asks questions, presses her to him in a wild embrace, brushes back the hair that hides her pale brow, covers her face with frenzied kisses, bursts out in convulsive laughter. In his wild joy, he has forgotten that he is going to die. Juliet is breathing. Juliet! Juliet! But a terrible pain gives him warning: the poison is working and burning at his vitals! 'Oh, potent poison! Capulet! Capulet! Mercy!' He goes down on his knees in supplication, deliriously believing he sees Juliet's father, come to take her from him again. ${ }^{145}$

As many commentators have discussed, this movement is almost entirely mimetic in its effect. Cairns states that it 'was the direct reliving in music of what he saw on the stage of the Odéon twelve years before, when Kemble and Harriet Smithson played the star-crossed lovers and the production ended with their deaths'. ${ }^{146}$ As has been previously stated, all of the events of this scene, remembered by Berlioz, have an easily identifiable musical representation in this movement. (See Exx. 2.5 - 2.9). Indeed, Berlioz's contemporary Stephen Heller said, 'the music could be mistaken for a rehearsal of an exceptionally dramatic opera performed by the orchestra alone to an empty stage. ${ }^{147}$

\footnotetext{
${ }^{145}$ Berlioz, The Art of Music and other essays (A Travers Chants), p. 226.

${ }^{146}$ Cairns, Servitude and Greatness, p. 181.
} 
Another contemporary, August Morel stated that it "would be perfectly adapted to a mime show which would make the action intelligible to the spectator. But I do not think the expression of such details belongs in the realm of the symphony. ${ }^{, 148}$ And as Shakespeare himself once said, herein lies the rub. There are moments in this symphony that require at the very least a strong visual imagination if not an actual visual staging of the drama. The inclusion of these events directly inspired by the Abbott company's performance within Berlioz's own re-telling of the story reinforces the extent to which this symphony is indebted to the specific production Berlioz saw, rather than simply Shakespeare's text in itself. Berlioz himself noted that this particular passage 'would not be understood by anyone who was not familiar with Garrick's [and Abbott's] version of the play. ${ }^{, 149}$

The extent of the visual specificity that is being 'mimed' in Part VI can be reinforced on inspection of some lithographs by F. J.

Moreau. Perhaps the best visual record we have of performances of the Abbott Company is contained within a souvenir programme produced by Moreau in $1827 .^{150}$ This programme contained lithographs of scenes from performances of Romeo and Juliet accompanied by a commentary. As Elliot

\footnotetext{
147 Stephen Heller, 'To Robert Schumann, at Leipzig, Paris, Decemer 1893', published in two parts in the Revue et Gazette musicale de Paris, December 1839, pp. 546-9 and 560-2. This review was also published in the Neue Zeitschrift für Musik (1840), pp. 31-2, 34-6, 39-40, 51-2, 56. Translated and reproduced in full in Rushton, Berlioz, Roméo et Juliette, pp. 60-69.

148 From a review in Le Constitutionnel, Journal du Commerce, Politique et Littérature, 28 November 1839, partially reproduced and translated in Rushton, Berlioz, Roméo et Juliette, p. 77.

${ }^{149}$ Elliot, Jr., 'The Shakespeare Berlioz Saw', 303.

150 Ibid., 300.
} 
explains, 'Moreau's third lithograph is of the Tomb Scene [...]

Juliet sits half erect on her bier, reaching out to the expiring

Romeo. ${ }^{, 151}$ The accompanying comments states that we should understand this moment in the play primarily as 'Romeo's scene'. Interestingly Berlioz's music also narrates this scene primarily from Romeo's perspective - the music is clearly evoking Romeo's feelings of agony as the poison grips his body. Suddenly the music all but stops, all that is heard is a screeching downwards scale, long held notes, before he finally dies on a low A below middle C. (Ex. 2.6) Like these lithographs, this score is suggestive not only of the tomb scene but the tomb scene as it was performed in the Abbott company's 1827 performance of Romeo and Juliet.

Another example of the visual specificity this musical score contains in reference to the Abbott production can be found in the prologue. This time it is a detail from Moreau's lithograph of the first balcony scene that can be found in Berlioz's symphony. Again as Elliot points out, the chorus describes Juliet as dressed in a white gown, (Déjà sur son balcon / La blanche Juliette parait), and the lithograph devoted to the same first balcony scene also portrays Harriet Smithson to be wearing a white gown. ${ }^{152}$ Though this second example could simply be a coincidence of images associated with virtuous young women, the overall similarities between Berlioz's symphony and the Abbott company's performance, reinforced by Moreau's lithographs make the reliance of Berlioz's symphony upon its theatrical precedent hard to deny.

\footnotetext{
151 Ibid., 303.

152 Ibid., 301.
} 


\section{A CHORAL SYMPHONY? REVEALING THE OPERA WITHIN}

Berlioz stated, ironically, that the title of 'symphony' should not provide any cause for debate: 'On ne se méprendra pas sans doute sur le genre de cet ouvrage. Bien que les voix y soient souvent employées, ce n'est ni un opéra de concert, ni une cantate, mais une symphonie avec chœurs.' ['There will doubtless be no mistake as to the genre of this work. Although voices are frequently employed, it is neither a concert opera nor a cantata but a choral symphony.'] ${ }^{153}$ One immediately recognises the term 'choral symphony' as an allusion to Beethoven's own Ninth Symphony. Yet how this work should be understood has been a constant cause of contention amongst Berlioz scholars. Indeed this symphony has inspired many an essay of explanation. Micznik lists the various different descriptions that have been used to try and explain this dramatic symphony: it is not a symphony but a free cantata; it is just as much an opera as it is a symphony; a music drama for the concert hall; a concert opera; part tone poem part operatic scenes. ${ }^{154}$ Cairns maintains that this work should only be identified and understood as a type of dramatic concert work, following on in a tradition established by Berlioz's hero Beethoven. What is interesting about Cairns's position is his opinion that it should only be understood in this way and not as a type of hybrid opera. We must certainly not see this dramatic

\footnotetext{
153 Holoman (ed.), Roméo et Juliette NBE, p. xxviii.

154 Micznik, 'Of Ways of Telling: Intertextuality and Historical Evidence in Berlioz's Roméo et Juliette', p. 22. Albright suggests that this work is a descendant of Le Suer's 'experimental "mass-oratorios". See Albright Berlioz's Semi-Operas: Roméo et Juliette and La damnation de Faust, p. 47. Langford also suggests that this symphony is influenced by Lesuer [sic] but calls these experimental oratorios 'free cantatas'. See Langford, 'The "Dramatic Symphonies" of Berlioz as an outgrowth of French Operatic Tradition', 92.
} 
symphony as a type of consolation prize genre, thought up by Berlioz following the poor execution and reception of his first opera Benvenuto Cellini. Cairns maintains:

Even if things had been quite different and Berlioz free to fulfil his ambitions as an opera composer, he would still have devoted creative energy to the development of the dramatic concert work; that was always going to be a central preoccupation from the moment he discovered Beethoven... The Opéra as it was, with the attitude it enshrined and the singers it had, was no place for so sacred a theme. ${ }^{155}$

To try to mould Roméo at Juliette into a quasi-opera is certainly not appropriate. The illogical and repetitive sequence of events, the vocal absence of central characters and, instead, the inclusion of key instrumental movements make this task impossible. Yet its theatrical nature, at times analogous to grand opera, at times analogous to pure theatre itself, highlights the important influence that the story's original performative form had on Berlioz's own translation of the play into a musical score. One should also be aware of the fact that, along with Berlioz's desire to follow in the great footsteps of Beethoven, the composer also had a visual memory of the work that was so strong and precise that any singer attempting to play Juliet could only fail to realise Berlioz's intentions. It is precisely because of this strong and personally significant memory that there does seem to be ample evidence to suggest that Berlioz and his librettist were still working within a theatrical rather than purely musical idiom. This tendency towards the theatrical perhaps inadvertently explains why Berlioz created music that at times uncomfortably highlights the absence of a visual accompaniment.

${ }^{155}$ Cairns, Servitude and Greatness, p. 179. 
Whereas in Lélio, this absence was made obvious and significant, the absence of visual spectacle in Roméo et Juliette is more ambiguous. We do not have a plush velvet curtain to remind us of our necessary active role in visualising the music, this music, as Berlioz himself admitted, instead relies on an act of memory and specific re-creation.

There is one section of Berlioz's Roméo et Juliette that was not performed by the Abbott Company in 1827. It had become standard practice by the early nineteenth century to end Shakespeare's Romeo and Juliet with the real death of Juliet. There is no Friar Lawrence to explain what happened between the two lovers and the families are not reconciled. Indeed this cut, like the others, was intended to emphasise the 'romantic love-story, focussing almost exclusively on the emotions of the lovers, and affording only the most generalized moral. ${ }^{, 156}$ Yet Berlioz, in his symphony, did include an ending more akin to Shakespeare's, with an explanation from Friar Lawrence and the reconciliation of the two warring families. As almost all commentators agree, this final section also happens to be the most overtly operatic scene in the symphony as a whole. The Friar sings what can only be understood as an aria, followed by a chorus that belongs within the tradition of grand opera. While the ending from Shakespeare's play may not have been deemed appropriate for the theatre, the large ensemble this scene affords is ideal within grand opera traditions. What is interesting is that when Berlioz is not alluding to the theatrical performance he saw, he is composing music that in itself belongs within a genre belonging to spectacle. This does not then mean that this work is a 'quasi-

${ }^{156}$ Elliot, Jr., 'The Shakespeare Berlioz Saw', 298 
opera' but it certainly is theatrical in a way that the symphony is not.

Indeed though Cairns seems to deny any understanding of the work as akin to opera, other commentators have been more tempted to do so. Berlioz's negative generic labelling of the work as 'not an opera and not a cantata' should not distract one from the fact that its genesis and execution owe much to the visual traditions of these vocal genres. Unlike Cairns, Rushton believes that one shouldn't dismiss the failure of Benvenuto Cellini and its effect on Berlioz's approach to Roméo et Juliette. Berlioz's first opera had been a disaster and a great disappointment for the composer. The politics at work within l'Opéra meant that a composer like Berlioz, with no interest in following in the path of convention and tradition was facing an uphill battle with the Paris public at large. One cannot say that Berlioz did not want to produce another opera, but that in 1839 he simply could not produce another opera. Rushton admits that as much 'as one might dislike the idea of a favourite work resulting from its creator being constrained by external events, Jeffery Langford's statement that the dramatic symphony was a "temporary substitute for opera" has the ring of truth. ${ }^{157}$ The old adage that necessity is the mother of all invention is certainly applicable here. That this diverse work has elements of opera, cantata and symphony should not be adamantly denied simply because Berlioz asks us to do so. In a letter from the librettist Émile Deschamps to Berlioz we can see how Deschamps at least was thinking of this work as something akin to opera.

My dear collaborator

157 Rushton, Berlioz, Roméo et Juliette, p. 80. 
Here is another bit of the finale. Forgive me for sending it to you piecemeal like this, but that is how it's coming to my inspiration (if that's the word). If you have kept my notes could you let me have all my verses back, from the beginning till now? I need them to coordinate the whole thing and go over it in detail - I've not kept anything. When I've made a copy I can then send it all to you, if you like.

Come on, take heart! I am counting on you so much! This is going to be something unique. A libretto for a symphony! An orchestra representing an opera! And thanks to you it will all become something enchanting, while remaining utterly original. We'll meet soon. Thank you as always, and my homage at the feet of Mme Berlioz, who was your first and veritable muse. As for me, I'm merely a musette.

\section{Yours, \\ Émile Deschamps ${ }^{158}$}

Again we return to the idea that this is 'an orchestra representing an opera', an orchestra accompanying absent singers. It is also worth remembering that Berlioz considered dressing his choristers so that the Capulets and Montagues were differentiated - this suggests at least a small desire by the composer to allow some sense of the drama to be presented visually on stage. ${ }^{159}$ Moreover, there is a note at the end of Part I for the chorus to exit, 'Le choeur sort'. It seems that Berlioz could not help but think and imagine this work within visual parameters.

That Roméo et Juliette contains elements of opera was not lost on its first audiences either. Marie d'Agoult, in a letter to Liszt,

\footnotetext{
${ }^{158}$ Letter from Émile Deschamps to Hector Berlioz dated 21 June 1839, reproduced and translated in Cairns, Servitude and Greatness, p. 192.

159 Ibid., p. 193.
} 
describes a visit from the literary critic Charles Augustin Sainte-

Beuve, who 'spent a long time talking about Berlioz's

symphony. He inclines to the conventional common-sense

view: why not make it an opera? ${ }^{\prime 60}$ As Cairns point out, Marie

d'Agoult herself, 'when not writing for Liszt's eyes', was not

entirely taken with Berlioz's work. ${ }^{161}$ That Sainte-Beuve's view

represented the 'conventional common sense' would suggest

that this was a widely held opinion. Heller in a review to his

friend and composer Robert Schumann also wished for a visual

accompaniment to the music he heard:

Yet this music so clearly expresses the dramatic qualities of the situation, which it clothes in the most vividly striking colours, that it must inspire in the spectator the desire for a physical complement, and regret for the absence of scenery and staging. ${ }^{162}$

Berlioz tried to create something beyond opera, both out of circumstance and artistic temperament. These comments, emphasising the narrative aspects of the score, highlight a greater aesthetic movement beginning to take place in Paris at this time.

Another common theme in reviews from the premiere of Roméo et Juliette is the way in which if this work is not opera then it must be a type of 'programme' music. Again the long and detailed review of Heller provides us with an interesting window into the ideas and expectations of Berlioz's audience. Heller describes this work as a 'programme symphony' with an added

\footnotetext{
160 Ibid., p. 200.

161 Ibid., p. 200.

162 Stephen Heller, trans. and quoted in Rushton, 'Berlioz, Roméo et Juliette', p. 66.
} 
prologue at the beginning to inform the audience of the composer's intentions. Perhaps responding to Schumann's own criticisms of Berlioz's detailed programme of the Symphonie fantastique, Heller states that this sung prologue is one of Berlioz's 'best notions, especially when he not only needs to get general ideas across, as in his earlier symphonies (march to execution, ball scene, Sabbath night, pilgrims' march), but the connected scenes of a sublime tragedy. If his orchestral movements are to be understood in the way he meant, he has to make his intentions clear. ${ }^{, 163}$ What proceeds after this are contradictory statements about the value of programmatic music. Heller on the one hand defends Berlioz, pointing out that audiences 'have always admitted that music can express pleasure, sorrow, love, sadness, fear, majesty; do we need to debar Berlioz from translating such feelings into sounds and harmonies? ${ }^{\prime 164}$ Yet he goes on to dismiss the programme shortly afterwards, stating that:

[It] hardly matters that [the adagio] is 'about' the love of Romeo and Juliet rather than some other passion. What have we to do with Juliet confiding her love to the night, as the prologue tells us, with Romeo suddenly revealing himself to her, and with their happiness or anxiety? This is mere fiction, while the music is incontrovertibly real. Its melodies penetrate to the wellsprings of emotion, arouse a thousand diverse sensations, and move us to tears! $!^{165}$

That Heller's comments are contradictory points towards the wider artistic debate that is being fought across the continent.

\footnotetext{
163 Ibid., p. 61.

164 Ibid. p. 61.

165 Ibid., p. 64.
} 
Though this is a letter to Robert Schumann, James H. Johnson explains that the divide between absolute music and programme music was raging in Paris:

At the heart of the new way of hearing was the liberation of music from language, a process well underway among spectators familiar with the music of Rossini and now encouraged by programmes at the Opéra and the Société des Concerts. If the Rossinidominated decade of the 1820s was an apprenticeship in listening for the sheer thrill of the music, the 1830s was the time of mastering the new perspective, of exploring its implications and experimenting with ways of capturing and conveying music's meaning. Spectators describing the music of Beethoven and Meyerbeer asserted that listening was not an act of emotional decipherment; its expression did not depend upon identifying a mood, a familiar sound, or an image. The essence of music defied anything that specific. It was possibly even beyond words. ${ }^{166}$

Berlioz composed and premiered his work at the end of a decade in which the nature and capabilities of what music conveyed and how it conveyed it was hotly debated. How Berlioz experienced Shakespeare and what he went on to compose holds up the ideals of absolute music in a very programmatic way. The idea that Berlioz was not really composing a work that told a well-known story, but instead composing a work that re-told the experience of watching a story brings us very close to a key nineteenth-century pre-occupation. Could it be possible that Berlioz's first experience of Shakespeare was in essence, an 'absolute' one? Could the very removal of any visual anchors be Berlioz's version of 'absolute' opera? He did not understand English and instead relied on the inflection and tone of the actors to tell the story, almost as if he was experiencing this play musically. Aside from the aid of

\footnotetext{
${ }^{166}$ Johnson, Listening in Paris: A Cultural History, p. 270.
} 
gesture and movement, Berlioz had to create a lot of the meanings of the work himself. Perhaps it was precisely this ambiguity that he then wanted to re-create in his symphony. It was that vagueness that led him to turn away from the traditions and conventions of opera and instead distil his own experiences into instrumental music. In setting the most emotional and sensational sections of this story to instrumental music alone, was Berlioz re-creating his own first experience of the play?

Even though Berlioz is commonly held up as the 'poster-boy' for programme music, we shouldn't forget that most composers of programme music, Berlioz included, still courted ambiguity and vagueness, and there is certainly evidence that he intended to create this sense of ambiguity and vagueness within this work. A narrow conception of programme music taints our understanding of this work like nearly all of Berlioz's oeuvre. The burgeoning debate on the subject of programme music was often cause for comment in the reviews of the premiere of Roméo et Juliette. Yet Berlioz's own expressions of his intent points towards the possibility that he was trying to create a work based on the very ideals of absolute music. Berlioz stated that it is the 'very sublimity' of the passion shared between the two lovers that necessarily needs 'the language of instruments, a language richer, more varied, less restricted and by its very vagueness incomparably more potent'. When Berlioz declared 'Speak then, my orchestra!' we can understand that he had discovered a way of communicating with his audience that may be worthy of Shakespeare's tales. ${ }^{167}$ The passion, the fervour the earnestness of young love is incapable of being expressed

167 Cairns, Servitude and Greatness, p. 179. 
through language. Yet it seems that Berlioz is unable to commit completely to the ideals of the absolute music movement either. He has taken away voices, staging and scenery, yet the story and programme remains. Perhaps it is this curious mix of programmatic and essentially un-programmatic elements that make this work so rich, varied and full of unresolved questions. These same persistent questions soon appear in La damnation de Faust. And this time the ambiguity seems to demand resolution. 


\section{Part Two}

\section{From Semi-Opera to Opera: \\ Staging Faust}




\section{Chapter 3: Contexts of La damnation de Faust}

Berlioz's arrival in Paris in 1821 not only introduced him to the wonders of Beethoven, Shakespeare and the poetry of Thomas Moore, whose works and influence inspired Lélio and Roméo et Juliette, but it was also during this time that the composer discovered the work of Goethe, and in particular his treatment of the legend of Faust. James Haar dates Berlioz's first intention of writing an opera entitled Mephistopheles to between 1825 and 1826, though Julian Rushton states that Berlioz was only first introduced to Goethe's Faust through Gérard de Nerval's French translation in 1827 or $1828 .^{168}$ (Berlioz himself states in his Memoirs that he first experienced Goethe's Faust through Nerval's translation which was first published in $1828 .{ }^{169}$ ) Whatever the case, it was a work that Berlioz immediately identified with and the Faust legend was to become a continuous source of inspiration throughout his life. In 1828 Berlioz tried to gain a commission for a Faust ballet and in 1829 he considered composing a descriptive symphony on Faust. ${ }^{170}$ The protagonist of his iconic Symphonie fantastique, written only a year later and while the composer claims he was still 'under the influence of Goethe's poem', has certain parallels with Faust, though Rushton claims that 'there is no evidence that the

\footnotetext{
${ }^{168}$ James Haar, 'The operas and the dramatic legend' p. 83; Hector Berlioz, La damnation de Faust (Supplement), Hector Berlioz. New Edition of the Complete Works, Vol. 8b, ed. Julian Rushton (Kasel, Basel, Tours, London: Bärenreiter, 1979), p 455. Henceforth La damnation de Faust NBE (Supplement).

169 Berlioz, The Memoirs of Hector Berlioz, p. 103.

${ }^{170}$ See Berlioz's letter to the Directeur des beaux-arts Vicomte Sosthène de la Rochefoucauld dated 12 November 1828, and Berlioz's letter to Humbert Ferrand dated 2 February 1829, in Berlioz, CG vol. I pp. 217, 232; see also Rushton (ed.), La damnation de Faust (Supplement), p. 455.
} 
symphony uses music intended for either [earlier] Faust work. ${ }^{, 171}$ Berlioz's first extant compositions based on Goethe's drama are his Huit Scènes de Faust, commenced in September 1828 and published in 1829 as his Opus 1. Though this publication was soon regretted by the composer and the score withdrawn, Berlioz would return to this eclectic group of compositions, and assimilate them into one of his most admired, imaginative and controversial large-scale compositions - La damnation de Faust. Berlioz first returned to his Opus 1 in 1844 with the intention of revising Marguerite's 'Romance' and the 'Chœur de Soldats' for performance. While this performance never came to fruition, this revision evidently stirred something within the composer and when Berlioz left for Vienna on 27 October 1845 he took with him the Huit Scènes de Faust along with some new verses on the legend composed by the journalist Almire Gandonnière. While touring Germany and Hungary, Berlioz grew impatient, realising that new material would take too long to be sent, and soon began writing his own verses. As Berlioz states in his Memoirs: 'As soon as I had made up my mind to do it [compose La damnation de Faust], I had also to resolve to write most of the libretto myself; for the fragments of Gérard de Nerval's translation... which I intended to rework and include in the score, plus two or three other scenes written to my instructions by M. Gandonnière before I left Paris, together amounted to less than one sixth of the work. ${ }^{, 172}$ Beginning with the 'Invocation à la nature', work on his Damnation de Faust began in earnest. Little more than a year later La damnation de

\footnotetext{
${ }^{171}$ Berlioz, The Memoirs of Hector Berlioz, p. 104; Rushton (ed.), La damnation de Faust NBE (Supplement), p. 455.

172 Berlioz, The Memoirs of Hector Berlioz, p. 449.
} 
Faust, a 'légend dramatique' organised into four parts was first performed.

\section{A COOL RECEPTION AND QUESTIONS OF GENRE}

La damnation de Faust was premiered on 6 December 1846 at the Opéra-Comique in Paris and was both a critical success and a commercial disaster. Though many favourable reviews were published, there were only two performances, both of which were poorly attended; a third performance was cancelled. As Holoman states, this was the biggest financial loss Berlioz was ever to experience. ${ }^{173}$ The lack of interest in Berlioz's new work was caused by a confluence of poor luck. The only venue that was available to Berlioz was the Opéra-Comique, 'a hall to which the public was unaccustomed to coming on Sunday afternoons. ${ }^{174}$ The fee for hiring the hall, a cool 1600 francs, was so 'exorbitant' that the ticket prices had to be doubled. ${ }^{175}$ When Berlioz was to write of this disaster in his Memoirs, he stated that a major reason for its failure, aside from the impressive apathy of the Parisian public, was the fact that he had 'no star singer'. ${ }^{176}$ Indeed Herman-Léon, the bass engaged to sing the role of Mephistopheles, was having trouble learning his role, compounded by the constant cuts and changes that were being made just before the premiere; Gustave Roger, who was singing the role of Faust, claimed not to understand his character; and Madame Maillard as Marguerite was, as Holoman

\footnotetext{
${ }^{173}$ Holoman, Berlioz, p. 340.

174 Ibid., p. 340.

175 Berlioz, The Memoirs of Hector Berlioz, p. 451; Holoman, Berlioz, p. 340.

${ }^{176}$ Berlioz, The Memoirs of Hector Berlioz, p. 452.
} 
states, 'accomplished but not fashionable. ${ }^{, 177}$ That audiences preferred to stay warm at home, rather than venture out in the snow to listen to the crackling fires of Berlioz's hell, was also unfortunate. Though friends of the composer realised that this composition was his most impressive and important work to date, (and subsequently gave a banquet in his honour), Berlioz was nonetheless devastated by the neglect of the wider public. He wrote that '[n] othing in my career as an artist wounded me more deeply than this unexpected indifference. ${ }^{178}$

Rushton, amongst others, points out that another reason the work was initially so unpopular was that the Parisian audience 'was not interested in large-scale music, other than opera for which it wanted scenery, costumes, and dancing. ${ }^{179}$ But opera this work is not and the ambiguities of genre in Berlioz's Damnation have long been a point of contention. One could say that Berlioz himself is responsible for this continued confusion. La damnation de Faust throughout its conception seems to have been described in various different ways. In a letter to his friend Joseph d'Ortigue, Berlioz asks him to 'Thank Dietsch for me...tell him I'm setting up some hard work for him with my grand opera Faust (concert opera in four acts) which I'm working at furiously and which will soon be finished. ${ }^{180}$ A note, 'Fragment de Faust, Drame de Concert en 4 actes', appearing on an album-leaf dated Vienna 12 January 1846 shows the term

\footnotetext{
177 Holoman, Berlioz, p. 340.

178 Berlioz, The Memoirs of Hector Berlioz, p. 452.

${ }^{179}$ Rushton (ed.), La damnation de Faust NBE (Supplement), p. 458.

${ }^{180}$ Letter from Hector Berlioz to Joseph d'Ortigue dated 13 March 1846, in Berlioz, Selected Letters of Berlioz, p. 224.
} 
'opera' to have been dropped completely, yet when Berlioz presented his libretto to King Louis-Philippe later in the same year he labelled the work an 'opéra-legend in four acts'. ${ }^{181}$ The term 'legend' is also used for the printed libretto of 1846 and in press notices. ${ }^{182}$ 'Opéra de concert' appears in the autograph score. By 1856, two years after its publication, Berlioz refers to La damnation de Faust in a letter to his sister Adèle as his 'dramatic legend'. ${ }^{183}$ The various descriptions of the work as a cantata, including its classification as such in the index of Berlioz's Memoirs edited by Cairns, seem appropriate considering that Berlioz organised his composition into four parts rather than four acts.

Regardless of La damnation de Faust's various labels it was consistently identified by the composer as a concert work and indeed many critics state outright that it should remain as such. Rushton writes that this work, 'really is a concert opera'. ${ }^{184}$ James Haar states more emphatically:

In the end the Damnation did not become an opera, nor should one try to make it into one. In this period of his life Berlioz was thinking not of Wagnerian Gesamtkuntswerk but of musical-dramatic works that crossed and recrossed the border between the symphonic and the operatic. ${ }^{185}$

\footnotetext{
${ }^{181}$ Rushton (ed.), La damnation de Faust NBE (Supplement), p. 457; Letter from Berlioz to His Majesty King Louis-Philippe King of the French dated 17 November 1846, in Berlioz, Selected Letters of Berlioz, p. 232.

182 Rushton (ed.), La damnation de Faust NBE (Supplement), p. 457.

${ }^{183}$ Letter from Berlioz to Adèle Suat dated 3 March 1856, in Berlioz, Selected Letters of Berlioz, p. 339.

${ }^{184}$ Julian Rushton, 'Genre in Berlioz' in The Cambridge Companion to Berlioz ed. Peter Bloom (Cambridge: Cambridge University Press, 2000), p. 50.
} 
When Berlioz did consider crossing that border into the operatic with his La damnation de Faust, he felt that many revisions to the score would be necessary. Though constantly disappointed and shunned by the authorities within the opera world of Paris, Berlioz's talents were more appreciated overseas. Indeed Berlioz was invited to move to London and take on an English opera company under the impresario Louis-Antoine Jullien, which he did, arriving in London in November 1847. Jullien promised to make Berlioz's fortunes and presented him with the directorship of his own opera company. The impresario, who had shown himself to be a canny businessman, as well as 'one of the most noted duellists in Paris', however was perhaps a little too optimistic in his assessments of establishing an opera company in London. ${ }^{186}$ Though the company successfully staged an English version of Donizetti's Lucia di Lammermoor, it was soon bankrupt, Jullien's fortunes disappearing alongside it. Yet before this collapse, when Berlioz was finally presented with an opera company eager to perform his compositions, the composer did indeed return to his $L a$ damnation de Faust.

\section{MÉPHISTOPHÉLĖS - A SPECTACULAR OPERA}

Berlioz's decision to develop his Faust composition into an opera most likely sprung from the fact that it would be much easier and quicker to rework an already finished score than to compose an entirely new opera. The most interesting information on what this opera could have been can be gleaned

\footnotetext{
${ }^{185}$ Haar, 'The operas and the dramatic legend', p. 89.

${ }^{186}$ Cairns, Servitude and Greatness, p. 392.
} 
from the letters between Berlioz and the librettist Eugène

Scribe, who the composer approached to adapt his text. In these

letters Berlioz documents the changes that he felt necessary to turn this concert work into opera proper. Doubtless the list is not exhaustive or comprehensive, but even these preliminary changes are significant. Tellingly the opera was not to be called 'Faust' but rather 'Méphistophélès'. A practical reason for this change lies in the fact that Jullien had briefly contemplated staging Spohr's Faust of 1816 with a libretto by Josef Karl Bernard. As Berlioz points out, a change in name would certainly avoid any confusion and create a point of distinction between the two works; even if the audience didn't confuse the two, they would immediately recognise Berlioz's different approach to the Faust story. The dominance of the devilish figure of Mephistopheles was due not only to the wonderful dramatic and musical possibilities this character affords but also because Berlioz was writing for the renowned bass singer, Pischek, who Berlioz felt could really embody the diabolical. The composer was eager to capitalise on Pischek's talents. As he wrote in a letter to Scribe:

Cela donnera plus d'importance au rôle destiné à Pischek et détournera les comparaisons entre notre ouvrage et ceux de Goethe et de Spohr. Pischek est peut-être le plus grand chanteur dramatique de notre époque $[. .$.$] il est d'une taille très avantageuse, et il a$ littéralement le diable au corps. ${ }^{187}$

[This will give prime importance to the role destined for Pischek and divert comparisons between the work in question and that of Goethe and of Spohr. Pischek is perhaps the most talented dramatic singer of our

${ }^{187}$ Letter from Berlioz to Eugène Scribe dated 26 November 1847, in Hector Berlioz, Correspondance générale: III 1842-1850 ed. Pierre Citron (Paris: Flammarion, c.1972) p. 473. (Hereafter CG vol. III) Translation mine. All further translations are mine unless stated otherwise. 
times... he is of a very advantageous height, and has a sense of being literally possessed.]

Along with a new name, this composition also needed additional scenes. The opera was to start in the depths of hell with the Princes of Darkness drawing straws to decide who would travel up to earth to seduce Faust. Berlioz states that he'd like an inferno that was sombre and silent to contrast with the later more triumphant and noisy hell:

les princes des Ténèbres assemblés pour choisir celui d'entre eux qui ira sur la terre séduire Faust. On va au scrutin et le nom de Méphistophélès sort de l'urne. Je voudrais ici un enfer très sombre, ténébreux et silencieux, pour contraster avec le Pandoemonium [sic] de la fin. A la proclamation du nom de Méphistophélès il y aurait seulement une sorte d'illumination subite et brève comme un éclair et un cri terrible de joie infernale. ${ }^{188}$

[the princes of darkness assemble to chose which one of them will travel to earth to seduce Faust. They take a vote, and the name of Mephistopheles is selected from the urn. Here, I would like an inferno that is very sombre, dark and silent, to contrast with the later Pandaemonium. At the proclamation of the name Mephistopheles, there would be a kind of abrupt authoritative light like lightning and a terrible hellish cry of joy.]

Interestingly these descriptions reveal the composer to be constantly considering the visual picture that he wanted to illuminate with his music. Jullien was also interested in the kinds of visual scenes that would suit Berlioz's score; both were already thinking about the practical aspects of turning this imaginative work into a viable theatre production. The composer instructs Scribe not to worry too much about the

188 Ibid., p. 474. 
frequent changes of scene, for this was normal practice in London:

Ne vous gênez pas pour les changements de décors, on en fait ici jusqu’à cinq dans un acte. ${ }^{189}$

[Don't worry about the changes of scenery, there will only be five in one act.]

Berlioz also informs him of the images that Jullien had thought of for the final hellish and divine scenes:

Puis un Pandoemonium [sic] immense et un ciel final, dans lequel Jullien a l'intention de faire reproduire les effets des merveilleux tableaux de peintre apocalyptique anglais Martinn [sic]. ${ }^{190}$

[Then an immense pandaemonium and finally heaven, in these scenes Jullien intends to reproduce the amazing effects of the apocalyptic paintings of the Englishman Martin.]

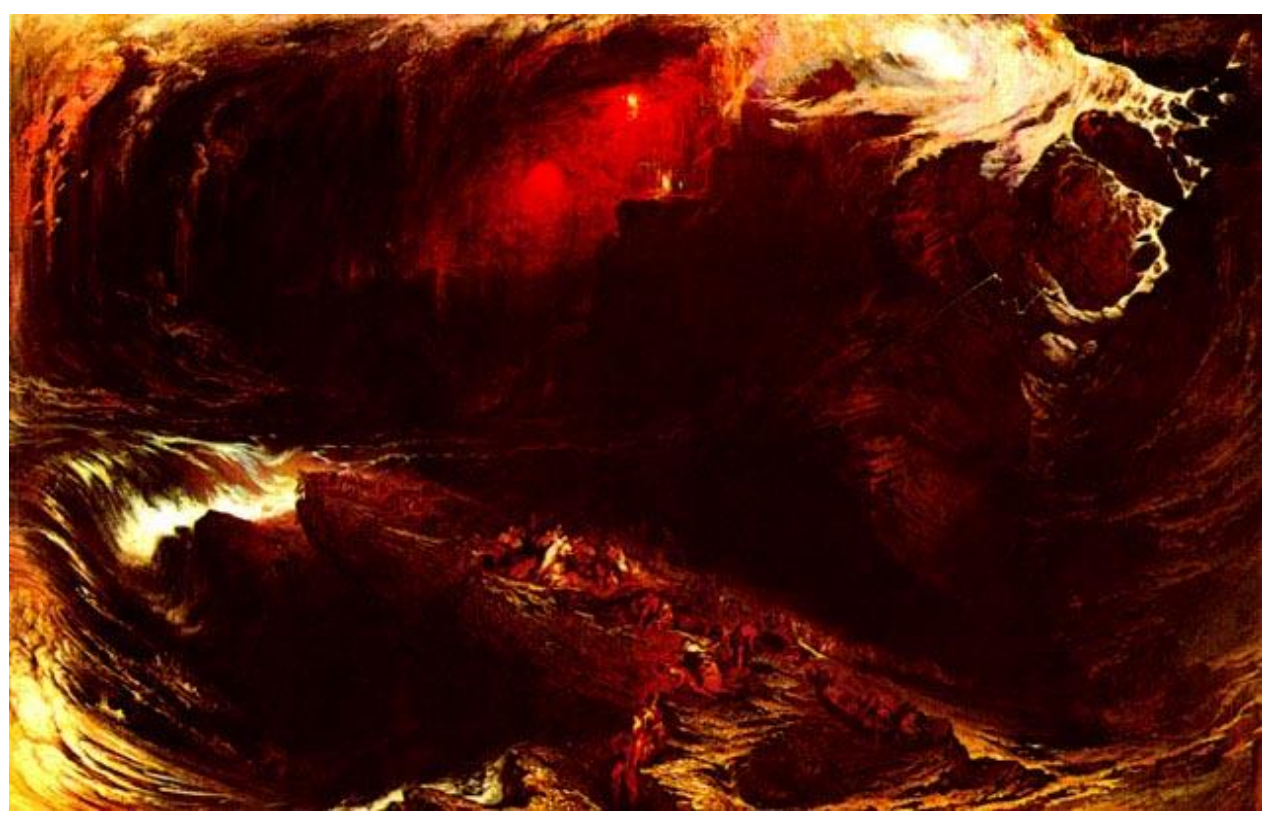

Figure 3: John Martin's The Deluge 1834.
189 Ibid. p. 474.
190 Ibid. p. 474 
The fact that Berlioz and Jullien were planning to use the paintings of John Martin in this operatic Méphistophélès is interesting especially as other artists also saw a parallel between the French composer and English painter. Heinrich Heine describes Berlioz as:

[A] colossal nightingale, a lark the size of an eagle, such as existed, we are told, in the primordial world...Indeed, for me there is something primitive if not prehistoric about Berlioz's music. It makes me see visions of mammoths and other beasts long extinct, fabulous empires of preternatural depravity, and many a cloudclapped, impossible wonder. Its magical strains conjure up Babylon, the hanging gardens of Semiramis, the marvels of Nineveh, the mighty constructions of Mizraim, as we see them in the pictures of the English painter Martin. ${ }^{191}$

That Berlioz's music was felt to be so visually descriptive perhaps naturally encouraged these associations with the fine arts. Indeed the metaphor of Berlioz as a visual artist is prevalent in a lot of writing about the composer. As Katharine Ellis has described, 'Berlioz embodied the ideal of the fusion of the arts; equally adept at writing words and notes, he was presented both as a poet and a painter in sound. ${ }^{192}$ Ellis has collected a selection of quotations from Berlioz's contemporaries that describe how Berlioz's instrumentation was compared to 'a subtle treatment of colour and light by a fine painter'; Heller describes how 'with artists such as Berlioz, poetry, music and painting exist simultaneously'; Maurice Bourges suggests that the best preparation for listening to L'enfance du Christ is to 'take a stroll round the Louvre... the

\footnotetext{
${ }^{191}$ Heinrich Heine, Lutetia, quoted and translated in Berlioz, The Memoirs of Hector Berlioz, pp. $524-525$.

192 Katharine Ellis, Music criticism in nineteenth-century France, p. 221.
} 
sight of most of these expressive paintings, particularly the earliest and most naïve, would be an excellent preparation for listening to the new score and feeling it more keenly. ${ }^{, 193}$

The preoccupations of Berlioz while attempting to translate $L a$ damnation de Faust into an opera, as we will soon discover, seem to be the very same issues that become problematic when future artists try to tame this concert work for the stage. Berlioz, like later commentators and directors, recognised the practical difficulties to be overcome when attempting to stage $L a$ damnation. These difficulties seem especially interesting and problematic when one takes into consideration the already strong visual imagination at work within this composition.

\section{A GALLERY OF MUSICAL PICTURES}

James Haar, in his chapter on Berlioz's operas and his dramatic legend from The Cambridge Companion to Hector Berlioz, describes Berlioz's compositional style in order to explain why his operas were perhaps not as successful as his symphonic works. As Haar states:

[A] procedure common to both genres [opera and symphony] in the hands of Berlioz is selection of episodes or scenes, all well suited for musical treatment, which form not a continuous narrative but rather an assemblage of characteristic musical portraits and landscapes, a kind of gallery devoted to the subject. ${ }^{194}$

\footnotetext{
193 Ibid., p. 222.

${ }^{194}$ Haar, 'The operas and the dramatic legend', p. 84. (Italics mine)
} 
This same comment could be applied to Berlioz's Roméo et Juliette. It seems understandable why commentators are keen to draw analogies between La damnation de Faust and opera if indeed all of Berlioz's self-labelled operas share a similar tendency towards the episodic. Haar's description of Berlioz's approach to composition as creating a 'gallery' of pictures on one subject is an apt description for his La damnation de Faust. Yet, it is this very aspect of his style - his tendencies towards episodic portraits rather than a linear story - that makes this work a little paradoxical. As already discussed, grand opera throughout the nineteenth century valued the lavishly spectacular tableaux that episodic treatments of a narrative made prominent. Yet Berlioz, while exploiting this treatment of narrative in opera, removes the very visual function these tableaux or episodes are supposed to make possible. Though a lot of nineteenth-century music can be described as episodic rather than linear, Haar maintains that Berlioz is nevertheless unique: 'A good deal of nineteenth-century opera can be described in this way, but with Berlioz it is a consciously chosen and strongly emphasized feature of his work whether symphonic or operatic. ${ }^{195}$ One could almost think that Berlioz was proud of this aspect of his creativity. In the annals of history, Berlioz has been remembered as a 'father' figure of programme music, yet he claimed stridently when defending a fragment of his Faust score, 'I would not have written my music to a programme, but a programme to my music. ${ }^{, 196}$ His genius could not be restricted or hampered by programmes, but programmes, even when well known, must necessarily be bent

\footnotetext{
195 Ibid.

${ }^{196}$ Letter from Hector Berlioz to François-Joseph Fétis dated 22 July 1860 in Berlioz, Selected Letters of Berlioz, pp. 388-389.
} 
to his own creative will. A prime example of this attitude can be seen in Berlioz's choice to begin his Faust legend in the plains of Hungary as a way to include the 'Rákóczy March' within his Damnation, much to the chagrin of German critics. As Berlioz describes in his Memoirs: 'A person like Faust may after all have any journey ascribed to him, no matter how outlandish, without violence being done to plausibility. ${ }^{, 197}$ Berlioz also felt no need to set the entire Faust story but simply selected the episodes that sparked his imagination. His own description of the compositional process of this score is very revealing of this aspect of his character:

Once launched, I did the verses that I lacked as and when the musical ideas came to me [...] I wrote it where and when I could: in coaches, in trains, on steamboats, even in towns I visited [...] The rest was written in Paris, but always at odd moments unpremeditatedly - at home, at the café, in the Tuileries Gardens, even on a milestone in the Boulevard du Temple: I did not have to search for ideas; I let them come and they presented themselves in the most unpredictable order. ${ }^{198}$

This fragmented, irregular approach to its composition is reflected back in the nature of La damnation as a whole. Haar maintains that La damnation de Faust should not be performed as opera due to this very episodic, fragmented tendency, and it is this same aspect of Berlioz's style that has been so difficult to overcome in the performance of Berlioz's actual operas.

\footnotetext{
197 Berlioz, The Memoirs of Hector Berlioz, p. 450; German critics were angered by Berlioz's choice to begin his legend in Hungary. See Berlioz's reply in his preface to score included in Hector Berlioz, Hector Berlioz New Edition of the Complete Works, Vol. 8a La damnation de Faust, ed. Julian Rushton (Kassel, Basel, Tours, London: Bärenreiter, 1979). (Hereafter La damnation de Faust NBE.)

198 Berlioz, The Memoirs of Hector Berlioz, pp. 449-451.
} 
Though Haar claims that it is this episodic nature of Berlioz's creativity that makes the transition to the stage so difficult I would like to return to his description of Berlioz creating a gallery of images. I maintain that it is not only the episodic nature of this composition but also the very visually specific tendencies within Berlioz's score that make staging La damnation de Faust a complex process. Rushton and Rodgers have both described sections of the score that can be understood as being visually prescriptive, and where we can see how Berlioz has indeed created both an aural and imaginative 'picture'. Rodgers describes how the 'Ballet de sylphes' contains within its score a specific visual scenario; whereas Rushton highlights the way in which the music of the end of Part III uses the conventions of opera to prove staging to be impossible due to the implied visual relationships between the music and action. ${ }^{199}$

Let us first examine Rodgers' description of the form and dramatic content of the 'Ballet de sylphes' in more detail:

In the ballet [de sylphes], Mephistopheles's spirits, their work completed and Faust now fast asleep, dance around Faust as he dreams peacefully. A circular form is naturally appropriate. This is a round dance of sorts and a lullaby; a simple repetitive form suits both the simple character of the spirits and the soothing, steady movements of their dance. They quite literally encircle Faust - one might imagine them repeating the steps of their dance as they go round and round him. The physical space of the imagined scene is reflected in the movement's form.

Here is the first thread mentioned above - musical circularity as an expression of non-musical circularity, something we hear acting as a metaphor for something we see. Or half-see: Damnation is a concert opera and was not meant to be staged, so the audience can only

\footnotetext{
${ }^{199}$ Rodgers, Form, Program, and Metaphor in the Music of Berlioz, pp. 24 - 33; Julian Rushton, 'Genre in Berlioz', p. 50.
} 
envision the sylphs dancing round and round Faust. But the metaphorical relationship between music and mental image holds all the same since the music is meant to arouse sensations in us that we recognize as comparable to those associated with witnessing a repetitive dance, and with seeing someone drift into reverie. ${ }^{200}$

Rodgers' subsequent analysis of the music shows how its structure, both as a ternary and a strophic form, can metaphorically create a sense of dizzying circular movement. We can literally hear Faust become hypnotized with this repetitive and structurally enchanting music. As Rodgers explains, 'Berlioz's form, mixing repetition and transformation, circularity and teleology, unfolds in a manner analogous to the unfolding of his imagined scene. ${ }^{201}$ Thus musical forms instil a sense of specific visual narration. Is it possible that Berlioz in particular structures his music as such to compensate for the lack of visuality within actual performance? If so then the addition of a visual accompaniment, of real ballerinas, may disrupt or disturb the specific visual images already imbedded within the music itself.

Another example of the specificity of the visual images Berlioz's music evokes immediately recalls the superb and audacious ' $\mathrm{La}$ course à l'abîme'. This movement is filled with evocative and dramatic musical images. Indeed this scene begins with a note stating that Faust and Mephistopheles gallop on two black horses and as the scene progresses there are various notes included above the string section describing the movement of the horses. (For an example see Ex. 3.2.) The audience can

${ }^{200}$ Rodgers, Form, Program, and Metaphor in the Music of Berlioz, p. 25. (Italics mine).

201 Ibid., p. 32. 
easily hear the thundering of the horses' hooves as they gallop towards the inferno. (Ex. 3.1) This constant rhythmic motive of semi-quaver followed by two demi-semi-quavers is used imitatively to evoke the horses' movement. When Faust momentarily questions Mephistopheles, the strings gradually slow and come to a complete stop literally as the horses do. (Ex. 3.2) We soon hear that there is a group of praying women and children, yet the horses' gallop doesn't slow and we can hear the innocent scream as they are trampled. (Ex. 3.3) One of the most frightening parts of the entire score, and arguably one of the most effective passages in Berlioz's entire compositional output, is his depiction of the monstrous beasts heralding Faust's descent into the darkness. The discordant trombones, tuba and ophicleide combine to create a truly hellish scene. (Ex. 3.4)

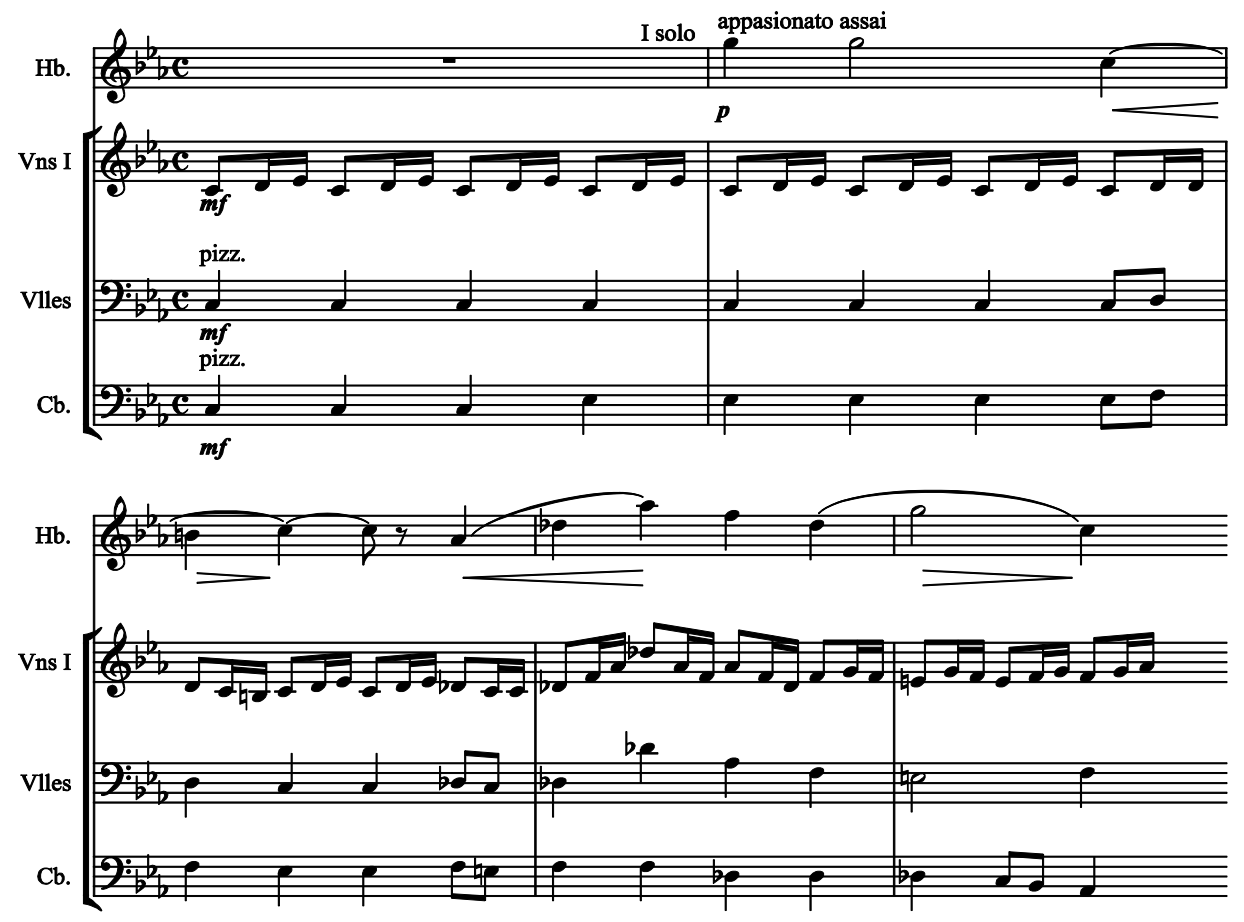

Example 3.1 'La course à l'abîme' bars 1-5: horses galloping. 

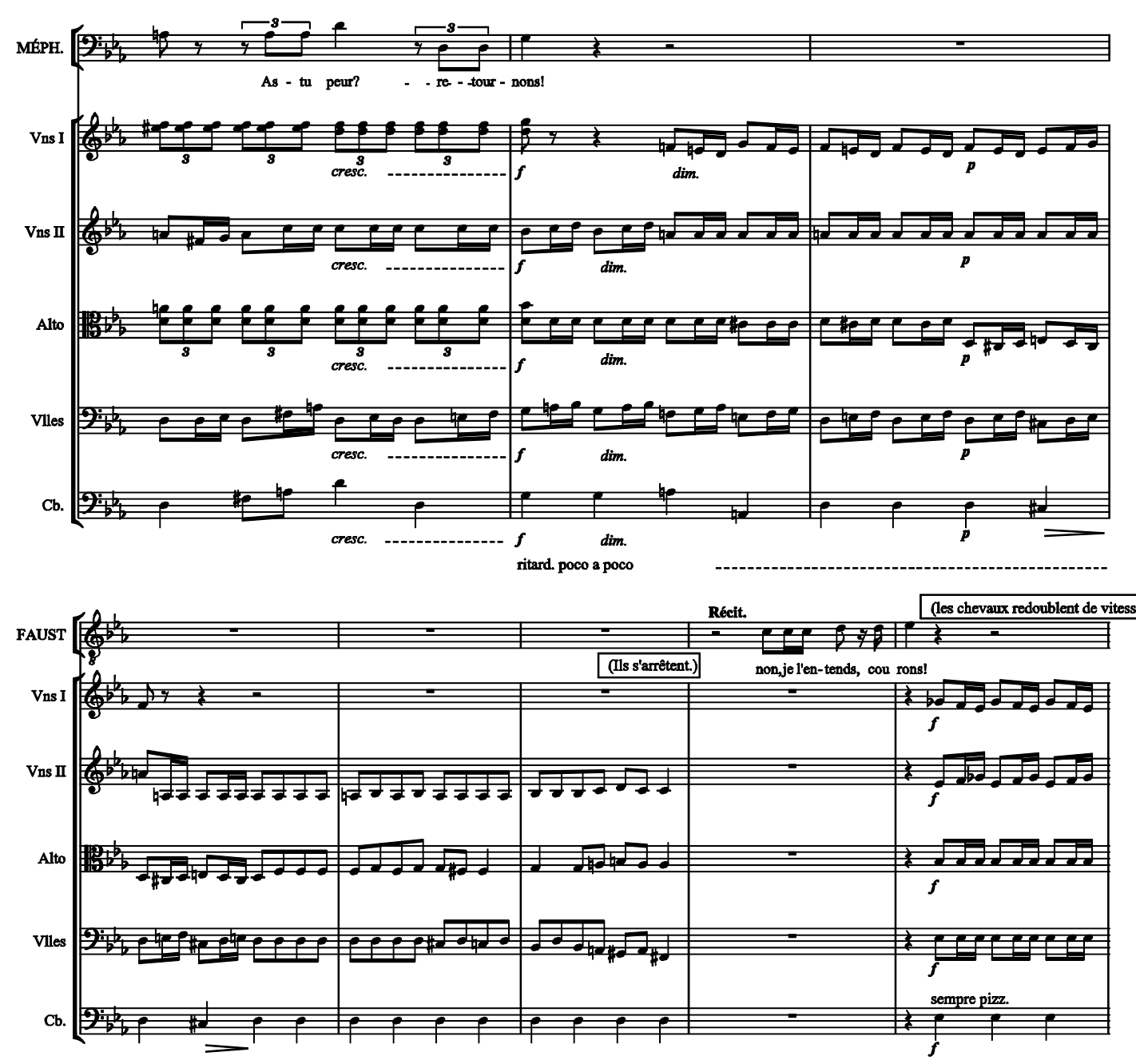

Example 3.2 'La course à l'abîme’ bars 83-90: horses slowing. 

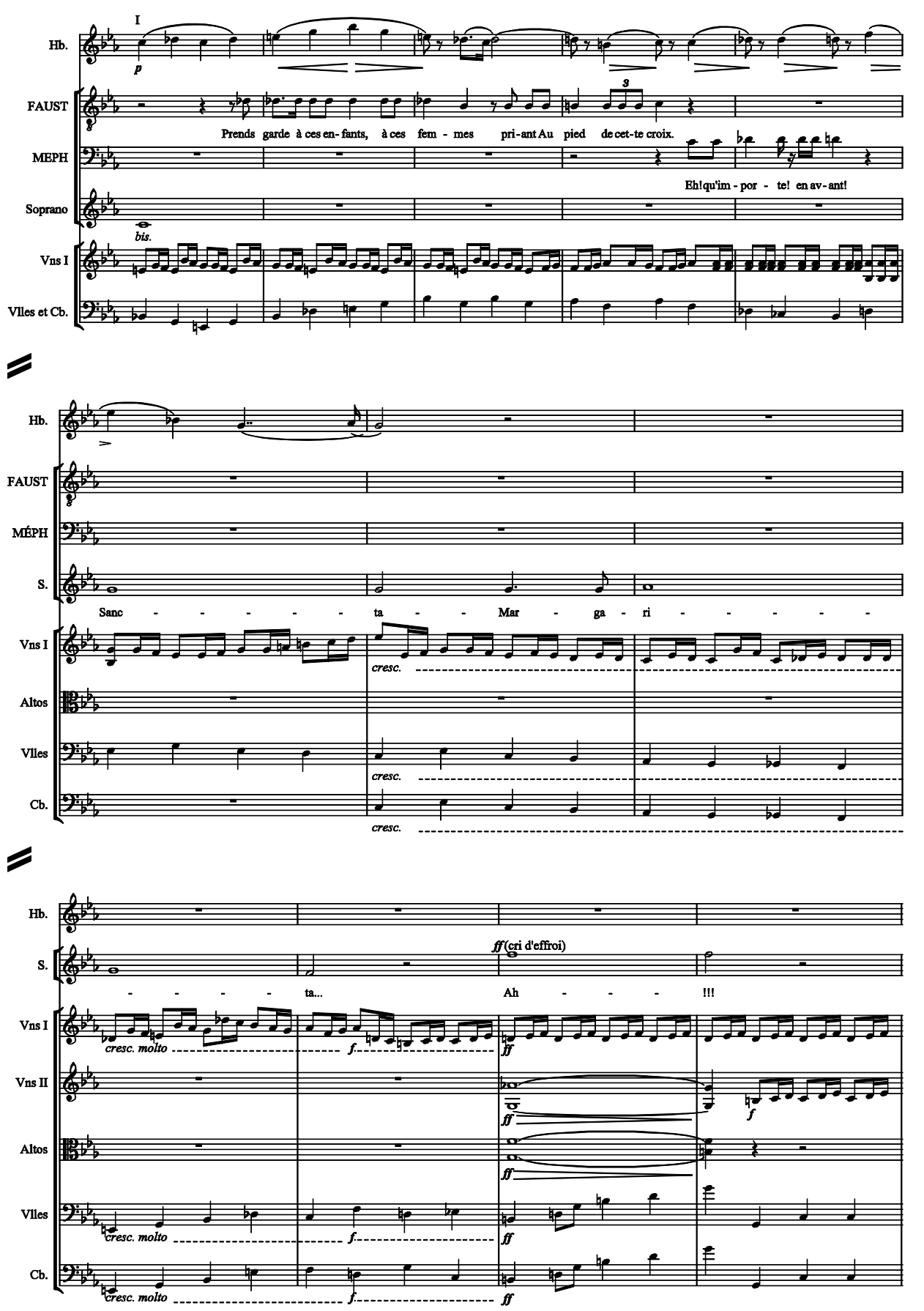

Example 3.3 'La course à l'abîme' bars 42-53: praying women and children trampled by horses. 

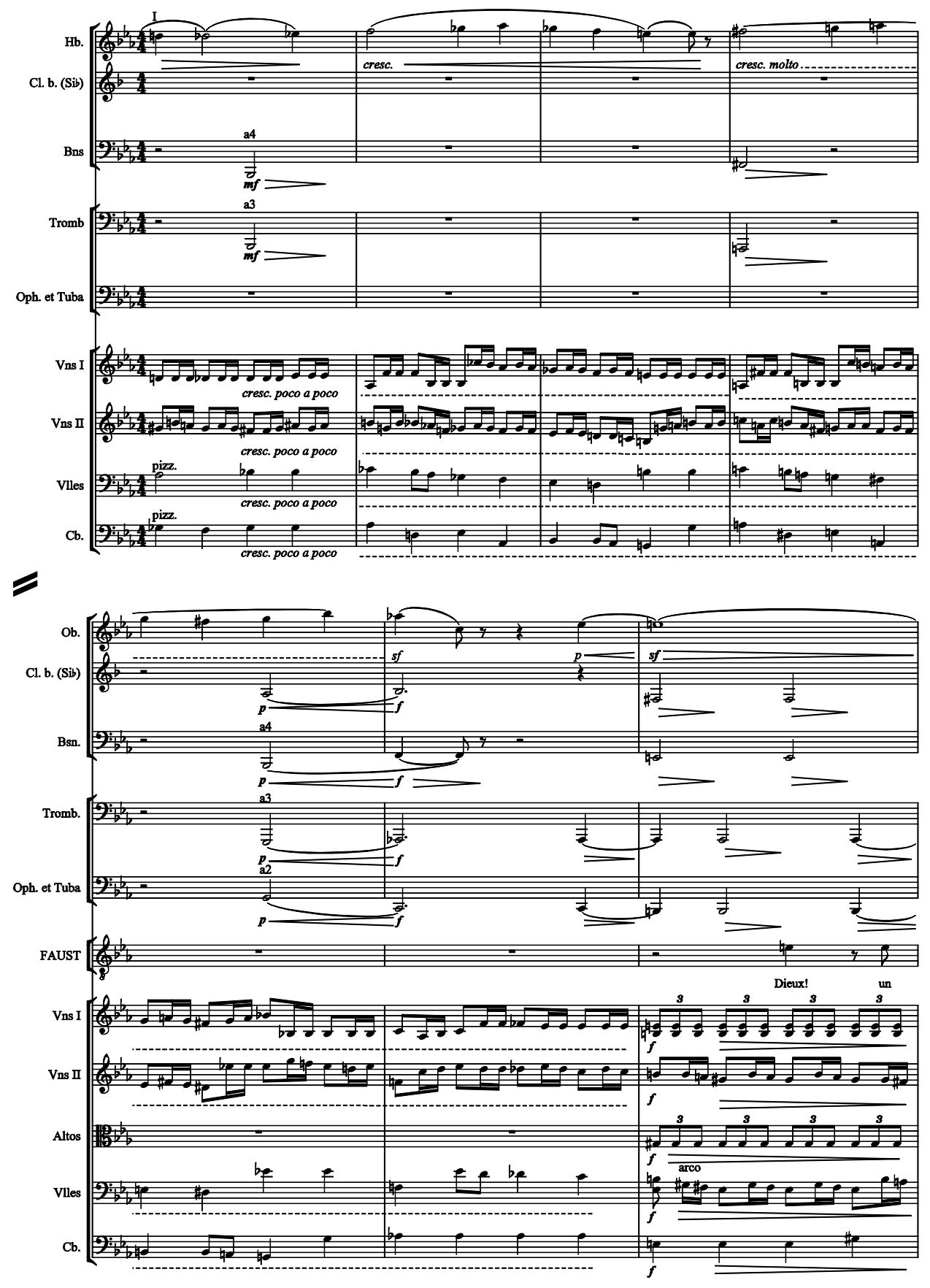


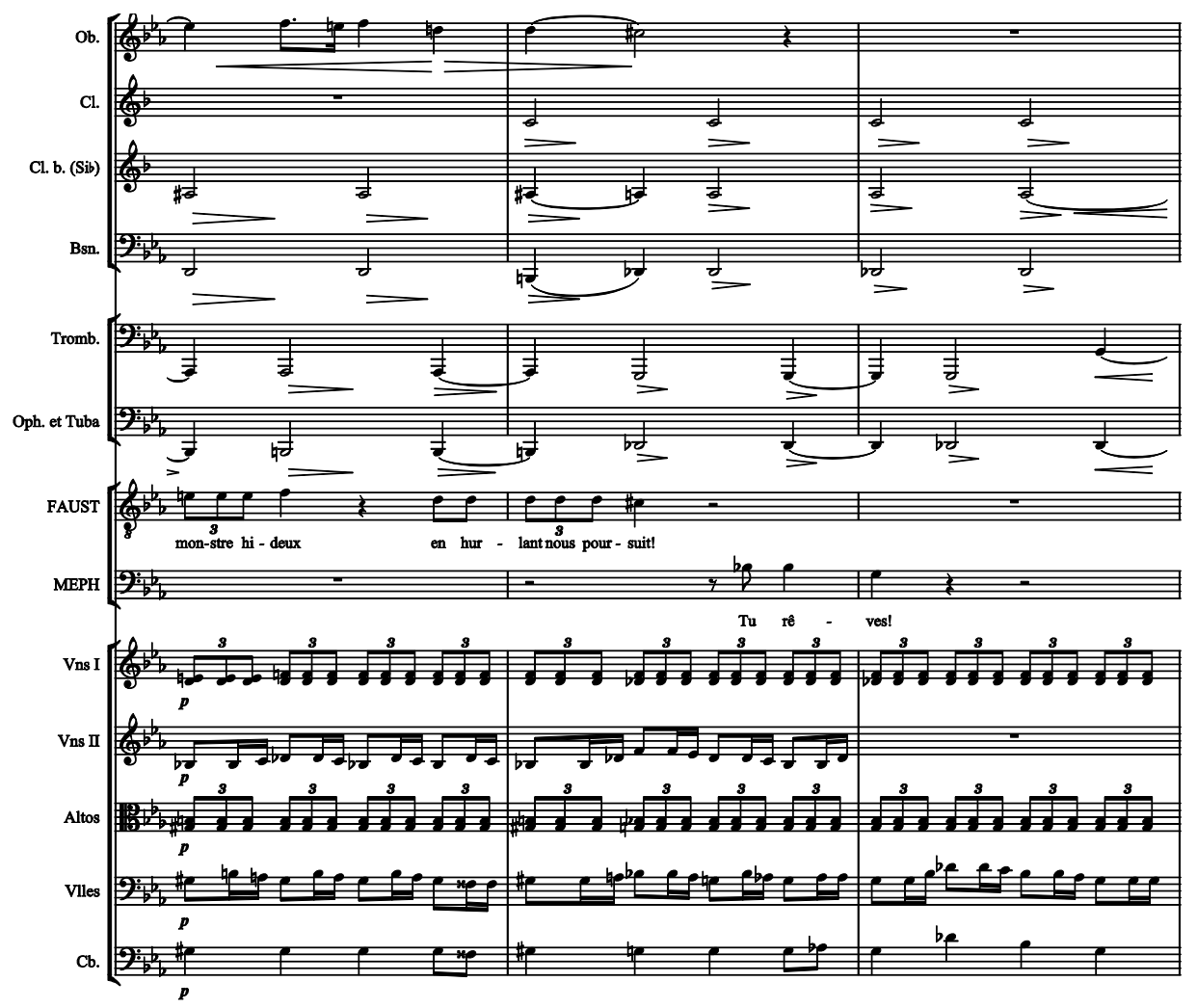

Example 3.4 'La course à l'abîme' bars 61-70, hideous monsters hiding in the brass section.

Perhaps the most difficult aspect of this particular piece is the fact that it describes frenetic and rapid traveling movement. In other diabolical operas of the nineteenth century, there is no comparable climax that incorporates physical movement in a similar fashion. Instead we can have successions of various dark and demonic, but essentially static, tableaux. In Weber's groundbreaking Der Freischütr, the famous 'Wolf's Glenn' scene can be seen to have many similarities to Berlioz's 'La course à l'abîme', except that the 'Wolf's Glenn' scene is static - monstrous birds, a hurricane, trampling horses can all be heard, even seen, but not necessarily physically experienced. The dancing debauched nuns of Meyerbeer's Robert le diable, are static in the sense that 
they are not moving between different locations and are contained in a single tableau. Robert and his demonic father Bertram are always either arriving or leaving situations but there is no rapid movement on stage from place to place as happens in 'La course à l'abîme'. Bertram's own plunge into the fiery pits of hell simply requires the appropriate use of a trap door. ${ }^{202}$ In Berlioz's time, I would argue that it was nigh impossible to create an appropriate visual action for this suggestive and colourful music. Nothing from within Berlioz's nineteenthcentury world could adequately portray various movements that were so unworldly and frenzied. That is precisely the point of Berlioz's programme as enacted in this 'légende dramatique'. Any actual enactment of this scene could never live up to the well- exercised images that Berlioz himself undoubtedly conjured up within his own mind.

When Rushton describes La damnation de Faust as a 'concert opera', he suggests that it has to be so performed because this work, though it contains many set pieces characteristic of nineteenth-century opera, uses them to create un-stageable scenarios. ${ }^{203}$ One such unpractical scene, according to Rushton, takes place throughout Part III. At the end of scene X from Part III, Mephistopheles hides Faust behind a curtain and disappears onto the street. Scene XI is devoted to Marguerite as she sings her 'Chanson gothique'. Scene XII, takes place on the street outside of Marguerite's house as Mephistopheles and his disturbing spirits sing the lovers a serenade. However, Mephistopheles finishes his serenade with the comment that he will now go and see his love-birds cooing. What

\footnotetext{
${ }^{202}$ H. Robert Cohen, The original staging manuscripts for twelve Parisian operatic premieres (Stuyvesant, NY: Pendragon, 1991) p. 218.

${ }^{203}$ Julian Rushton, 'Genre in Berlioz', p. 50.
} 
follows this statement is the beginning of the duet between Marguerite and Faust. Interestingly, this duet starts with a quotation from

Marguerite's earlier ballade. This quotation serves to transport us back in time to the moment Marguerite has stopped singing and presumably Faust has made an appearance from behind the curtain. We realise that Faust and Marguerite are thus singing their noumenal duet simultaneously while Mephistopheles sings them his phenomenal serenade. Thus we can understand that when Mephistopheles bursts in to begin the trio and states that the villagers have been woken from all the singing and are on their way to discover the lovers, he has come directly from the street as he informed us earlier. It would be difficult to stage two scenes simultaneously as would be required to make complete sense of the complex musical allusions taking place throughout this movement. Admittedly, concepts of what was possible to stage were increasingly being questioned throughout the nineteenth century. ${ }^{204}$ However, this system of cross-references does serve to continue to distance Berlioz's drama from a specifically operatic model and we are invited instead to repose in the theatre of the mind, where Mephistopheles can indeed be in several places at once. He is literally an incorporeal being not ruled by the laws of nature. Significantly we can see how Berlioz uses the very absence of a physical visual element as an opportunity to explore the unworldly and diabolical nature of Mephistopheles. What is not possible to be reflected physically or visually can be made so within the complex cross references of a musical-literary score. Indeed a closer analysis of the score shows the way in which Mephistopheles is constructed as an overarching

204 Of course the innovations of Wagner immediately spring to mind. Verdi's Macbeth, which was first performed only a year after La damnation in 1847, has examples of fantastical and seemingly impossible events being staged. For an interesting discussion on the various movements between music that is heard only in the psychological realm of Macbeth and then heard in phenomenal world of the opera see Elizabeth Hudson, '...qualche cosa d'incredibile...': Hearing the Invisible in Macbetb', Cambridge Opera Journal Vol. 14 No. 1/2, pp $11-29$. For a discussion of the metaphysical in music in the $19^{\text {th }}$ century and a response to Abbatte's Unsung Voices see Gary Tomlinson, Metaphysical Song: An Essay on Opera (Princeton: University of Princeton Press, 1999). 
creator, and darker themes of Berlioz's interpretation of the Faust legend soon begin to show themselves.

\section{MUSIC ANALYSIS}

Haar mentions the fact that the thematic material of the opening scene is strikingly similar to the thematic material from the Choeur de Sylphes, and indeed 'variations of it appear in several other prominent places in the score. ${ }^{, 205}$ (See Exx. 3.5 and

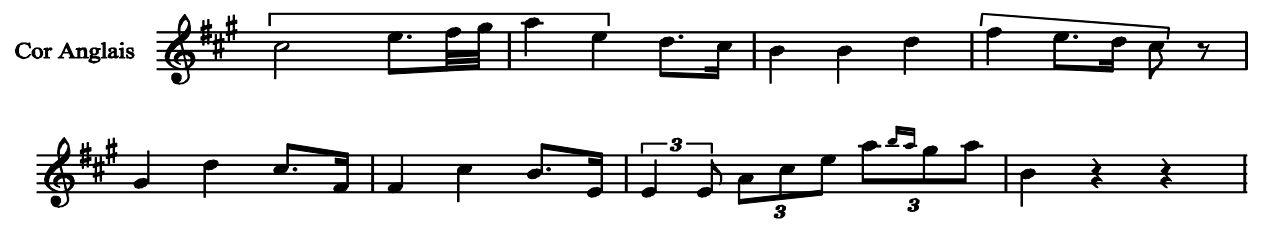

Example 3.5 Theme of the Choeur de Sylphes

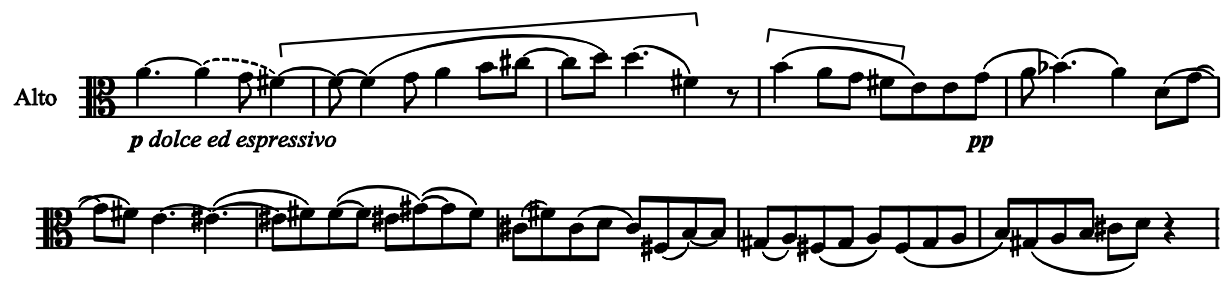

Example 3.6 Opening theme of Part I.

This could simply reinforce the idea that everything within $L a$ damnation de Faust is happening inside Faust's own imagination, which in turn is then projected out for all the audience to experience. However, another, more sinister interpretation is also possible and plausible. It is possible to read, in retrospect, the opening scene as being generated by the devil himself. In

205 Haar, 'The operas and the dramatic legend', p. 90. 
retrospect we can understand how the music of the peasants belongs to the devil. Everything soon becomes a construction created by Mephistopheles in which to lure Faust. The implication that Mephistopheles in some form is generating the music of the orchestra and even other characters can be seen at various other times in the score. It is Mephistopheles who gives Marguerite her first musical material. We first hear Marguerite when she sings her song of the 'Roi de Thulé'. Yet this melody is clearly first heard in music that belongs to Mephistopheles. Indeed at the beginning of Scene $\mathrm{X}$ we first hear the music that signifies Mephistopheles's entrance, this is then followed by the uncanny tune of Marguerite's 'Le roi de Thulé', first heard in the (devilish?) clarinets. (Ex. 3.7) There is also an orchestral theme that heralds in Mephistopheles's sudden appearances. (Exx. 3.8.1-3.8.3) These miniature fanfares perhaps imply that the orchestra operates at his behest. The title of the work itself, $L a$ damnation de Faust, already prefigures the ending of the work and suggests that the events contained within the work have already taken place. We must then ask ourselves who has survived these events to tell the story? The devil himself and his orchestra? Without the burden of visual representation, the Mephistopheles figure in this dramatic work is arguably more sinister than his embodied version could ever possibly be. Mephistopheles becomes present throughout the score, positioning himself in the role of narrator, composer and (ironically for Goethe’s 'Spirit of negation’ idea) creator. 

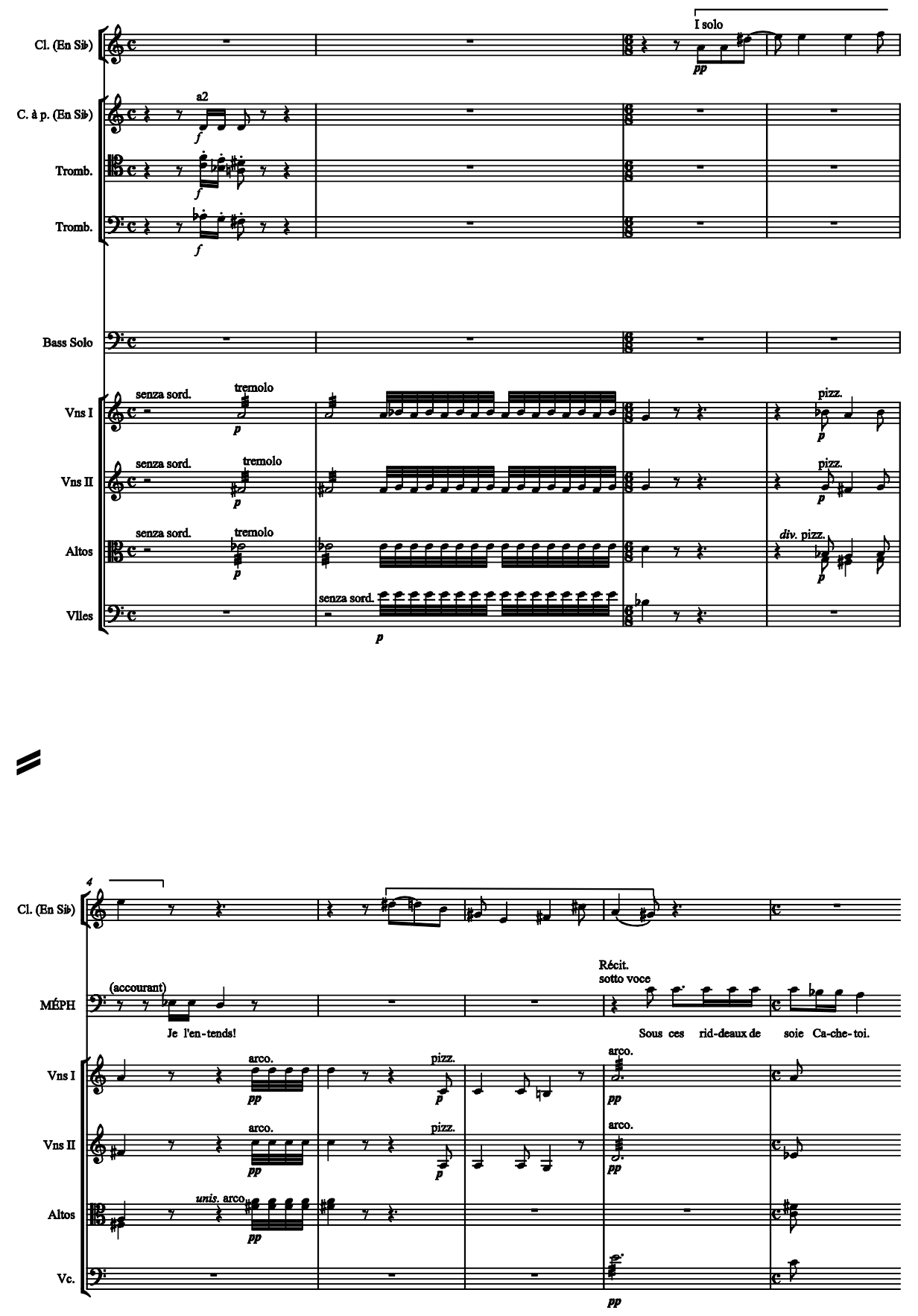

Example 3.7 Scène X bars 1-9. 


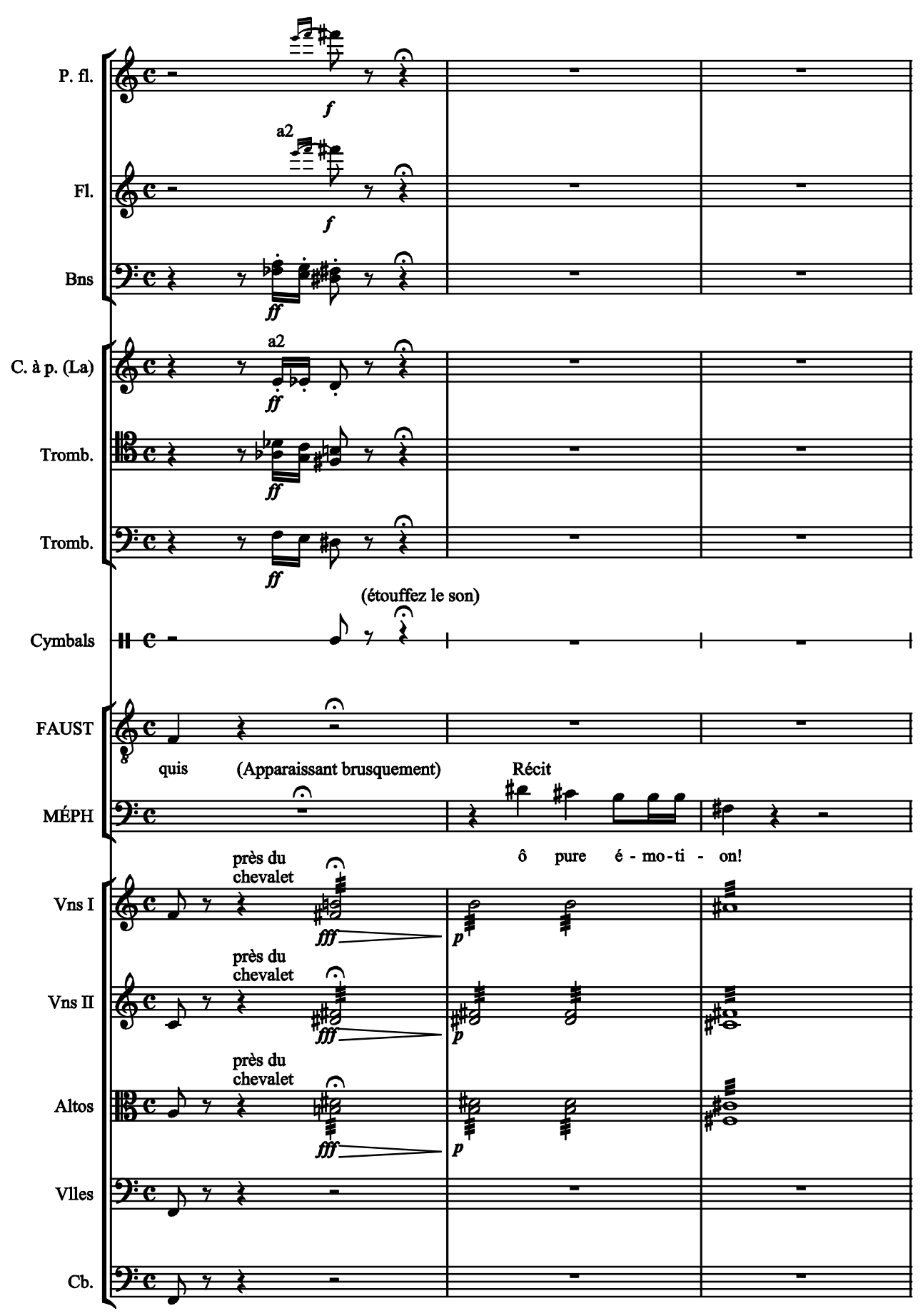

Example 6.8.1 Scène V, Mephistopheles’s first entrance, bars 1-

3. 


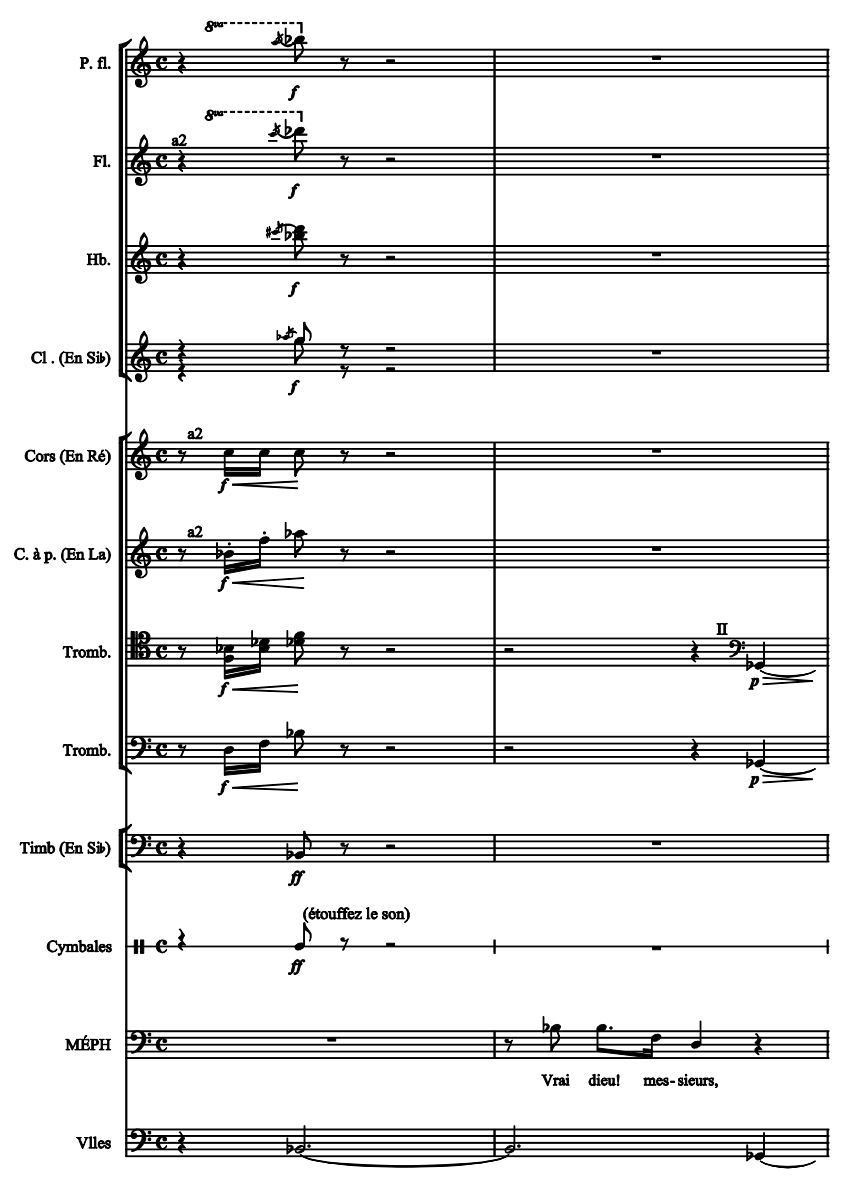

Example 6.8.2 'Chanson de Brander' bars 216-217 : entrance of Mephistopheles.

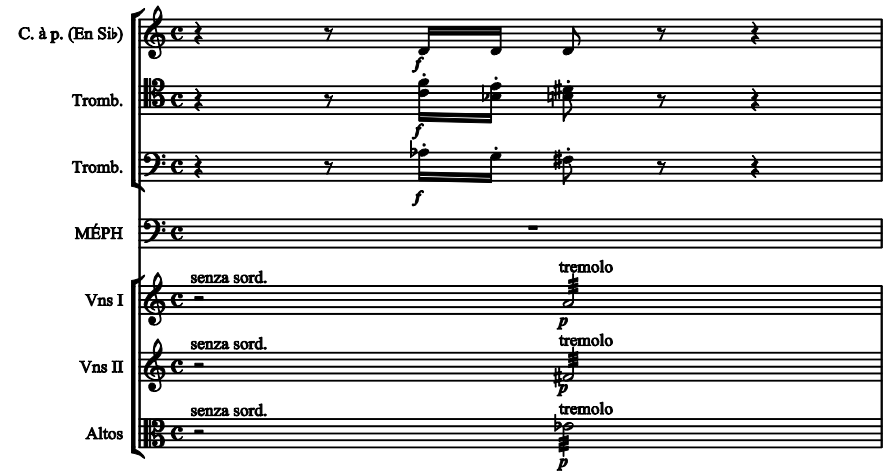

Example 6.8.3 Scène X bar 1: entrance of Mephistopheles. 
Carolyn Abbate states that music is a temporal medium that exists only in the moment that it is being made - it is an art form that, by its very nature, belongs to the present tense.

In terms of classical distinctions, what we call narrative - novels, stories, myths, and the like - is diegetic, epic poetry and not theatre. It is a tale told later, by one who escaped to the outside of the tale, for which he builds a frame to control its dangerous energy. Music's distinction is fundamental and terrible; it is not chiefly diegetic but mimetic. Like any form of theatre, any temporal art, it traps the listener in present experience and the beat of passing time, from which he or she cannot escape. No art is purely mimetic (that is, no art is merely the phenomenal world); rather, the mimetic genres move us by performing, they mime or even dance out the world in present time. ${ }^{206}$

Yet La damnation is not a stereotypical work and in certain ways

Berlioz's creation is indeed arguably much more akin to a

literary form such as the legend than to any theatrical tradition.

Indeed, fellow French composer Pierre Lalo felt that it was best to understand this work as analogous to a literature, as seen in

Lalo's review published in the 2 June 1903 issue of Les Temps.

Lalo cites text that Berlioz presumably wrote for L'Illustration of

21 November 1846:

Ce titre insolite d'opéra-légende indique une oeuvre destinée à être lue plutôt que représentée, et l'impossibilité de 'jouer' convenablement au théâtre les principales scènes de diverse actes, et notamment du dernier, justifie l'auteur de l'avoir choisi. ${ }^{207}$

[The unusual title 'opéra-légénde' implies a work destined to be read rather than performed, and the impossibility of suitably 'playing' within the theatre the diverse

\footnotetext{
206 Abbate, Unsung Voices, p. 53.

207 Pierre Lalo, review in Le Temps, 2 June 1903, quoted in Lesley Wright, 'Berlioz in the Fin-de-siècle Press' in Berlioz: Past, Present, Future ed. Peter Bloom (Suffolk: University of Rochester Press, 2003) pp. 171n.52.
} 
number of scenes and acts, especially the final scene, justifies the composer's choice.]

This tendency towards literary precedents rather than theatrical ones can also be seen in the extent to which the text of this score is substantially 'phenomenal' rather than the more 'noumenal' constructions of traditional nineteenth-century opera texts. ${ }^{208}$ The work of Abbate in exploring the various forms of narration and voice within both vocal and non-vocal music can be used in Berlioz's hybrid work to explore some of the 'problems' that arise when combining functionally different vocal and non vocal forms - opera, symphony and oratorio - as Berlioz has done in this score. In applying the analytical concepts of noumenal music or music that is not consciously heard by the characters singing - and phenomenal music or music that is consciously heard by the various characters in the narrative framework, we can begin to uncover different and distanced voices. ${ }^{209}$

Berlioz created a visual dimension to this work through the music in several ways; he used form to suggest physical movement; musical references and allusions to suggest specific visual events; and cross references to create a drama that is essentially ethereal and not of the body. The libretto, the majority of which was written by the composer, can also be seen to encourage specific visual imaginings within the work. If we are to begin to deconstruct the various voices, both extrovert

\footnotetext{
208 Abbate, Unsung Voices, p. xii.

${ }^{209}$ Abbate, Unsung Voices, pp. xi-xii.
} 
and hidden within the score, then an analysis of the libretto is also important. Certainly, nineteenth-century reviewers would often revert to an analysis of the libretto in order pass judgement on new operas as oftentimes the music was too 'difficult' to dissect for public dissemination. ${ }^{210}$ According to Abbate, using this point of difference, between the noumenal and phenomenal, one can then unearth corruptive and disturbing ideas and narratives embedded within the music that are put forth as normative and are delivered under the radar so to speak. Abbate states:

I believe that the pleasures of narrational interpretation derive precisely from awakening a 'second hearing' that enables us to sense when (for it happens but rarely) music can be heard as narrating, and more than this, to be aware of complex assumptions that encourage us to perceive such moments as narration [...] My readings $[\ldots]$ attempt to recognize both voice and narrative acts in music, to identify when and by what means music narrates, and to suggest that such loci are far from being normal or universal. They are disruptive and charged with a sense of both distance and difference: narrating in music will contain elements of the fantastic. Certain nineteenth-century works can thus be conceived as oscillating between a normal musical state (unscrolling, which may well be described in terms of events, tonal unwindings, thematic development, or the like) and rarer moments of narrating. ${ }^{211}$

What is unusual and perhaps troubling about Berlioz's work within a nineteenth-century context is the way in which Berlioz has subverted the operatic norm of his own time. Abbate states that moments of conscious phenomenal music are rare within nineteenth century opera contexts. What's more these moments

\footnotetext{
${ }^{210}$ Cairns, Servitude and Greatness, p. 164.

211 Abbate, Unsung Voices, pp. xi-xii.
} 
of phenomenal music disturb and disrupt the larger narrative of the work. What is the effect, then, when the majority of a work is significantly and obviously phenomenal in nature as is the case with Berlioz's La damnation de Faust?

\section{LIBRETTO ANALYSIS AND THE QUESTION OF STAGE DIRECTIONS}

Like many of Berlioz's scores, this work contains many different forms of vocal and non-vocal music. Perhaps the primary difference between this work and more conventional opera of this same period lies in the prevalence of phenomenal songs as opposed to noumenal arias and recitative. The entire first half of the score is quite episodic and, apart from Faust's own musings, is almost entirely phenomenal. Part I starts with Faust singing in the plains of Hungary when his thoughts are soon interrupted by a peasant chorus. Faust sings again, describing the Hungarian March that the audience then hears. Part II is also episodic. Faust sings of his despair (noumenally), the chorus then sings a (phenomenal) Easter Hymn. It is only when the devil enters that there is any kind of conversation between characters, replacing the previous direct monologues sung to the audience, yet the rest of Part II is then a progression of phenomenal songs. Part III is perhaps the most overtly operatic with more music that belongs entirely within a traditional nineteenth-century operatic tradition. (Though as Rushton highlighted earlier, curiously it is this music that cannot be convincingly embodied). The third part begins with an aria from Faust; Mephistopheles sings a 'moral' (and phenomenal) song that is then followed by a phenomenal song from Marguerite; the remainder of this third part is pure noumenal opera. The duet between Marguerite and 
Faust and the ensuing trio between Faust, Marguerite and Mephistopheles is a rare moment in this score where the three major characters actually interact musically and textually with each other. Instead of individuals and chorus singing monologues to each other or simply to the audience, this is a section of sustained dialogue, with all the repetition and ardent declarations of love typical of an opera score. (Elsewhere in the work the dialogue between Faust and Mephistopheles is often quite short and brisk. Faust, though often commenting on the music of the chorus does not interact directly with them.) Part IV continues in this operatic vein, with Marguerite's 'Romance' followed by Faust's 'Invocation à la nature'. Mephistopheles soon appears telling Faust of Marguerite's predicament. Their ride to hell is truly operatic in its dramatic scope. Yet, typical of Berlioz, this dramatic climax of the score highlights not the voices of the tenor and bass but the nightmarish colours of the orchestra. The opera then ends with two choruses. The first is from hell and scored to a hellish language invented by Berlioz; the other is Marguerite's apotheosis.

This gradual shift from predominantly phenomenal music to noumenal music across the entire work as a whole proves to be a little problematic in its dramatic intent and application to either the operatic stage or the concert hall. The fact that $L a$ damnation de Faust seems to contain various different musical forms and approaches to narrative is not surprising. This work is, after all, an augmentation of an already pre-existing collection of songs, the Huit scènes de Faust. The predominance of phenomenal songs throughout the first half of this score can, in part, be explained by the inclusion of various already composed pieces from that remarkable work of a very young Berlioz. 
Another explanation for the generic ambiguity of this work perhaps lies in Berlioz's own attitude towards the staging and musical dramatization of this literary work. His feelings are best expressed in his review of another Faust opera - that of Charles Gounod. When reviewing Gounod's Faust, Berlioz questions the very act of transforming the work into a musical drama and lambasts the bizarre atrocities based on the Faust story that have plagued Parisian audiences.

Non, non, non! vous ne savez rien par cœur, d'abord parce qu'il se peut que vous n'ayez point de cœur, et ensuit parce qu'en réalité vous n'avez jamais lu Faust, et que, l'eussiez-vous lu un soir pour vous endormir, comme on lit un roman de Paul de Kock qui ne vous endort pas, au contraire, vous ne le connaissez pas mieux pour cela. [...]Combien de fois n'a-t-on pas dérangé Goethe, qui lui-même avait dérangé Marlowe, pour mettre son œuvre en opéra, en légende, en ballet! Oui, en ballet. L'idée de faire danser Faust est bien la plus prodigieuse qui soit jamais entrée dans la tête sans cervelle d'un de ces hommes qui touchent à tout, profanent tout sans méchante intention, comme font les merles et les moineaux des grands jardins publics prenant pour perchoir les chefs-d'œuvre de la statuaire...

No, no, no! You know nothing by heart -- first because it is possible that you have no heart at all, and second because you've never really read Faust, and, if perhaps you read it one evening to lull yourself to sleep, as one reads a Paul de Kock novel that doesn't put you to sleep but does the opposite, then you don't know it any better for having done so. [...] How many times have we not disturbed Goethe, who himself disturbed Marlowe, in order to perform his work as an opera, a story, a ballet! Yes, a ballet. The idea of making Faust dance is the most staggering idea ever to enter the brainless head of one of those men who touch everything and profane everything without malicious intent, like the blackbirds and sparrows in the public parks that take as their perch 
masterpieces of statuary.... $]^{212}$

Though Paris was saturated with various versions of this tale, Berlioz was not convinced they understood Faust at all. (However, he does seem to have forgotten his own earlier attempt to write a Faust ballet...) If he was to create a musical telling of this story at all it would need to be appropriate for such a sacred topic. The resulting 'légende dramatique', which sits somewhere between oratorio and opera, is Berlioz's solution. Yet this mixture between oratorio and opera and between the self-conscious and purely dramatic form of story telling, creates problems for both director and conductor. These issues are perhaps almost entirely associated with the visual imagery embedded within the music of this score as we have already seen. There are textual uncertainties here that also require some attention. At times it is Berlioz's own inclusion of small programmatic notes that invite speculation.

This work starts with Faust wandering in the plains of Hungary at sunrise. This setting is annotated in the libretto, though if the audience is not fortunate to have a libretto on hand, they can gleam some information from the sung text alone. When Faust first sings, he begins by describing the environment that surrounds him. He describes how 'Des cieux la coupole infinie /Laisse pleuvoir mille feux éclatants [...] Je sens glisser dans l'air le brise matinale'. ['The infinite dome of heaven, / Rains down a thousand bright lights.' He can 'feel the gentle morning

\footnotetext{
212 Berlioz, Les musiciens et la musique (Paris: Calmann-Lévy, 1969), p. 285-286.
} Translation kindly provided by Dacia Herbulock. 
breeze in the air']. ${ }^{213}$ We thus can know from the text alone that it is dawn, and early enough that the stars can still be seen in the sky. What the audience cannot know at this point in the score, is that Faust is on an Hungarian plain. In the following scene, the libretto again informs us that Faust has now shifted to 'another part of the plain' where an army is advancing. ${ }^{214}$ This shift in scenery is also not described in the sung text. The approaching army can be clearly identified by the military idioms contained in the music. The only suggestion that Faust may be in Hungary is when he describes the passing soldiers as 'sons of the Danube'. ['Ah! les fils du Danube aux combats se préparent!'] 215 (Though this isn't entirely a clear reference as this European river runs through several different countries, including Germany, Slovakia, Croatia, Serbia, Romania, Bulgaria, Moldova, Ukraine as well as Hungary!) It is not until the end of Part One that the audience may identify the location as being situated in Hungary without recourse to a programme; here we hear Berlioz's infamous Hungarian March, which was a very popular crowd pleaser and composed and published before his Damnation de Faust was premiered. During the Hungarian March these sons of the Danube then 'pass by' as Faust 'moves away'. ${ }^{216}$ The initial setting of Faust in the Hungarian plains can be seen as an ingenious move by the composer to include his popular Hungarian March within the work as a whole; the smaller directions indicating the movements of a wandering Faust and instructing the soldiers to march past the protagonist

\footnotetext{
213 Berlioz, La damnation de Faust NBE, pp 6-11.

${ }^{214}$ This is also the subtitle of this scene - Scène III: Une autre partie de la plaine - Ibid., p 54.

215 Ibid., p. 55.

${ }^{216}$ There is a note in the score - (Les troupes passent. Faust s'éloigne) Ibid., p. 56.
} 
are a little more difficult to explain.

In Part Two, the location shifts from the Hungarian plains to North Germany. Faust is alone in his study. This new location, though hinted at, is never made explicit in the vocal text. Faust sings how, 'Sans regrets j'ai quitté les riantes campagnes [...] Sans plaisirs je revois nos altières montagnes; Dans ma vieille cite'... ['Without regret I left the smiling countryside [...]

Without pleasure I see again our lofty mountains ; in my old city'... ${ }^{217}$ When Faust and Mephistopheles appear in Auerbach's cellar in Leipzig, it is only the subtitle of the scene that tells us of their location ${ }^{218}$ There is no mention of the city or the specific cellar in any of the vocal music, (though the fact they are in a tavern is very obvious). When Faust and Mephistopheles travel to the banks of the river Elbe, there is only a written note to describe their exit from the tavern and the new destination is again only referenced in the title of the next scene. ${ }^{219}$ The fact that Faust is now sleeping on the banks of the Elbe is not mentioned at all in the vocal text. So too when Berlioz is transported to Marguerite's bedroom, there is only a brief mention of her 'virginal couch' within the sung text that would inform the audience as to his present location. ['Que j'aime à contempler ton chevet virginal!'] ${ }^{220}$ What is apparent is that Berlioz either assumes that the constant changes of location are irrelevant, (in which case why include them at all?), or he

\footnotetext{
${ }^{217}$ Ibid., pp 81-82.

218 Scène VI: La cave d'Auerbach à Leipzig. Ibid., p 116.

219 At bar 90 in the Chanson de Méphistophélès there is a note (Ils partent); Scène VII: Bosquets et prairies du bord de l'Elbe. Ibid., p. 166 and p. 170.

220 Ibid., p 255.
} 
assumes that these details of place and environment are already known and understood by his audiences. He has added these details in the libretto, somewhat succinctly, simply as a reminder. If it is the latter than this in itself seems like a contradictory assumption from Berlioz considering his strong critique, quoted earlier, of his audience's lack of knowledge and sympathy with Goethe’s Faust.

There seems to be a contradiction between Berlioz's assumption that the audience may have at least some knowledge of the more practical details of the Faustian legend and our knowledge of Berlioz's own frustrated feelings towards his audience. In her study of operatic performance and gesture entitled Mimomania, Mary-Ann Smart illustrates the often-disinterested practices of Parisian audiences. ${ }^{221}$ Smart reminds us that operatic performances on the Paris stage were given with the hall lights on; performances in general were treated more as an occasion to see and be seen. Opera was necessarily a formulaic art, able to inform audiences of the appropriate time to listen and the appropriate time to gossip. ${ }^{222}$ That Berlioz's audience were supplied with a libretto, we know. Our assumption that his audience ever read it, well... Has Berlioz created a work that is so generically ambiguous as to overcome the practices of nineteenth-century opera audiences? Perhaps we can assume his audience may have paid a little more attention to the libretto due to the interesting genre of La damnation, thus freeing the music of certain informative functions. It may also be possible

\footnotetext{
221 Mary-Ann Smart, Mimomania: Music and Gesture in Nineteenth-Century Opera (Berkeley: University of California Press, 2004), p. 21.

222 Ibid. p. 21.
} 
that Berlioz then uses this libretto to suggest and replace the many absent operatic conventions of gesture, movement and even dance, thus replacing the theatrical with the literary.

There are seemingly trivial and short notes of instruction scattered throughout Berlioz's score. When Faust allows Mephistopheles to show him the wonders of the world there is a note simply stating 'Ils Partent'. [They leave]. ${ }^{223}$ This note seems to have very little dramatic significance. Their departure is almost immediately accompanied by music that foreshadows their first port of call, Auerbach's Tavern. In this concert opera we can assume that the singers would not walk off the stage only to walk back on 17 bars later. Again at the end of this Scène VI there is another note stating 'Ils partent'. [They leave]. ${ }^{224}$ At the end of the 'Ballet de sylphes' there is a note that describes Faust 's'éveillant en sursaut'. [waking suddenly]. ${ }^{225}$ These notes are present throughout the score and seem to be little more than a guide for our imagination. There are also instructions here for characters that do not sing. In his score Berlioz has included two dances. The first is the 'Ballet de sylphes'. At the beginning of this scene there is a note above the harp section describing 'Les esprits de l'air se balancent quelque temps en silence autour de Faust endormi et disparaissent peu à peu.' [These airy spirits silently sway for some time above the sleeping Faust before disappearing little by little. $]^{226}$ This is the first mention of 'spirits of the air' and this instruction again

\footnotetext{
223 Berlioz, La damnation de Faust NBE, p. 114.

224 Ibid., p. 166.

225 Ibid., p. 213.

226 Ibid., p. 206.
} 
seems to be a way of guiding the audience's imagination, (perhaps even the performer's imagination), much like the programme of Berlioz's Symphonie fantastique. Berlioz replaces the real bodies of the absent dancers with the ethereal spirits of our imaginations through his libretto. It is worth noting that Berlioz need not be constricted by possible movements - his ballerinas can indeed be spirits and float, fly and disappear without concern for what is physically achievable. Indeed the metaphor of air-bound figures is used within the music itself - the harps almost exclusively play harmonics throughout this ballet. The second dance is the 'Menuet des follets'. At the beginning of this minuet there is a note: 'Les follets exécutent des évolutions et des danses bizarres autour de la maison de Marguerite'. ['The wills-o'-the-wisp dance their strange dances about Marguerite's house.' ${ }^{227}$ It seems that Berlioz has specific visual images in mind to accompany his music and the composer takes care to describe these. These descriptions of events not physically present again reinforce the identification of this work as much more akin to a literary prototype rather than a theatrical work.

Whereas earlier written suggestions of movement may not be related to any obvious matching musical material there are other examples when this does in fact occur. The character of Mephistopheles is almost always accompanied by a small note in the libretto describing his sudden appearance: at various times throughout the work Mephistopheles 'Apparaissant brusquement'; 'accourant'; 'entrant brusquement'. ['Appearing suddenly'; 'hurrying in'; 'bursting in'] ${ }^{228}$ Yet unlike the other

\footnotetext{
227 Ibid., p. 282.

228 Ibid., pp. 109, 258, 338.
} 
brief notes that appear throughout the score, this note seems often to have a rather dramatic and wonderfully devilish musical figure that accompanies it as already articulated above. (See Exx. 3.8.1-3.8.3) $)^{229}$ Berlioz is thus providing his audience with music accompanied by a programme that describes its very specific meaning and action. One can almost imagine these musical flourishes of Mephistopheles accompanied by a puff of smoke and the devil indeed very suddenly and magically appearing!

Is Berlioz being a little presumptuous in including within the libretto what his music may mean, dictating to our imaginations in a very specific way? The debate between the values of programme and absolute music has long been passionately fought since Berlioz's own time. It does seem that Berlioz in La damnation de Faust is rather eager to guide our mind's eye through all aspects of this work. Throughout the score Berlioz not only includes notes to describe the change of location or small brief notes describing entrances and exits of characters, there are also directorial or stage instructions present in Berlioz's libretto. It is here where the generic ambiguities of the score again become interesting. At the beginning of Part II, Faust contemplates his despair and lack of engagement with the world around him. All alone, he decides to end his life. Faust sings : 'Allons, il faut finir! [...] O coupe trop longtemps à mes désirs ravie, /Viens, viens, noble cristal, verse-moi le poison, /Qui doit illuminer /Ou tuer ma raison'. ['Come, I must finish it! ... O cup too long enraptured with my desires /Come, come, noble crystal, pour the poison /That must light /Or kill my

229 This figure is also highlighted in Gérard Condé, 'Commentaire musical et littéraire' L'avant-scène opera : Hector Berlioz La damnation de Faust, Vol. 22 ed. Gérard Condé (Paris: Éditions Premières Loges, 1995), p. 50. 
reason.'] ${ }^{230}$ At this point in the libretto there is a note describing Faust's actions: '(Il porte la coupe à ses lèvres. Sons des cloches. Chants religieux dans l'église voisine)'. [He lifts the cup to his lips. Bells sound. Religious chanting from the neighbouring church]. ${ }^{231}$ This seems like a strange anomaly for a concert opera. This is not a grand opera and there is no scenery, costume or props to help tell the story therefore a note that instructs Faust to lift a cup cannot be seen as literal. To add to the confusion Faust himself has already sung about the actions that are then subsequently described again in the libretto. Would the tenor singing this role be expected to mime the actions described? Would an audience find it visually strange to hear a singer describe their exact actions, accompanied by a note in the libretto describing the characters subsequent actions, yet see the singer do no such thing? There are similarly problematic passages throughout Part III. In scene nine there is a note at the beginning of Faust's Air stating that it is evening and he is in Marguerite's room. At the end of this air there is another note describing Faust, 'marchant lentement, examine avec une curiosité passionnée l'intérieur de la chambre de Marguerite.' ['walking slowly, examines with a passionate curiosity the interior of Marguerite's room']. ${ }^{232}$ When Mephistopheles arrives in scene ten, he hides Faust behind a curtain. Marguerite enters, 'une lampe à la main[...] Elle chante en tressant ses cheveux.' [Marguerite 'enters carrying a lamp' she then 'sings while plaiting her hair'.. ${ }^{233}$ When Mephistopheles sings to Marguerite, 'Il fait le mouvement d'un homme qui joue de la vielle.' [He

\footnotetext{
${ }^{230}$ Berlioz, La damnation de Faust NBE, pp. 84-86.

${ }^{231}$ Ibid., p. 86.

232 Ibid., p. 256.

233 Ibid., pp. 261 and 265.
} 
'makes the gestures of a man playing the hurdy-gurdy'. $]^{234}$ It is perhaps possible that the singers would have mimed certain actions and there are precedents for this in the performance of lieder. ${ }^{235}$ Though these directorial notes are only mentioned in the libretto and often not reflected within the vocal text, there are also moments in the sung text that could also be visually problematic. In the scene in Auerbach's cellar, the male chorus sing 'Oh! qu'il est pale, et comme Son poi lest roux'. ['Oh! How pale he is and how / red is his hair. $]^{236}$ As no costumes were intended to be used in the performance of this work, is the audience again being asked to ignore what they are actually seeing in front of them and revert to their imaginations? (The practicalities of only having a pale redhead to sing the bass role seems a little restrictive!) Of course there is a substantial elephant standing in the room. The fact that singers do not match their descriptions within opera of course is nothing new. Audiences are long used to seeing European soprani sing the roles of Turandot and Butterfly. The suspension of disbelief has been a primary necessity within the opera theatre as middle age men, (or women), take on the roles of young virile men. The difference is that opera specifically invites, even demands, this suspension of disbelief of its audience. Though I would argue that issues of realism are becoming a very interesting problem for increasing numbers of modern directors, opera itself, even today, is often afforded quite a wide licence. Is this contract between audience and performers still present when there are not the costumes, scenery and smoke screens to distract the

\footnotetext{
234 Ibid., p. 312.

${ }^{235}$ See Inge van Rij, Brahms's Song Collections (Cambridge: Cambridge University Press, 2006); and Smart, Mimomania.

${ }^{236}$ Berlioz, La damnation de Faust NBE, p. 312.
} 
audience's more critical faculties? The quite specific notes and descriptions within La damnation de Faust perhaps serve to guide the imagination of the audience, yet within this concert work, the descriptions of physical movement, appearance and gesture also act to divorce the voices of Marguerite, Faust and Mephistopheles from the bodies of the musicians who are present and singing the roles within the concert hall. Unlike opera, the bodies of the singers do not need to become the bodies of their characters but instead their voices need to become disembodied. Berlioz while constantly inviting us to see actions and events is perhaps inviting us to see them specifically through our mind's eye and do away with the physical bodies of all the instruments completely. To some extent these notes reinforce the idea that the singers, like the orchestra, are simply instruments sounding in a concert opera. Yet I would argue that this becomes highly problematic when Berlioz shifts from the prevalence of phenomenal music throughout the first half of this work to a more 'normal' noumenal operatic idiom in the second half. It is still more problematic when one considers that Faust is the only character throughout the entire work whose music is entirely noumenal.

\section{LISTEN! NOUMENAL AND PHENOMENAL NARRATIVES IN $L A$} DAMNATION DE FAUST

Berlioz throughout his libretto is very careful to continuously entreat the audience to listen to his score. ${ }^{237}$ Faust, Mephistopheles, Marguerite and

237 Curiously, Wagner's Tannbäuser, first performed in 1845 and Verdi's Macbeth, first performed in 1847 , also both contain many entreaties to listen. The fact Tannhäuser outlines a singing contest makes these entreaties not unexpected. [See Abbatte chapter] The invitations to listen in Macbeth are interesting in that they highlight the shift between phenomenal and noumenal music, signifying the access the audience has to the psychological 
the Chorus are constantly describing what it is that they hear. This description not only informs the audience of the meaning of specific musical phrases and gestures but reminds them that this is a work in which the environment and scenic elements of the storytelling are delivered aurally rather than visually. This happens from the very beginning of the score. Faust first sings, 'J'entends autour de moi le réveil des oiseaux /Le long bruissement des plantes et des eaux'. ['I hear about me the awaking of the birds, /The drawn-out murmuring of the plants and waters...' $]^{238}$ Berlioz is careful to ensure that the audience too can hear these sounds from the orchestra. The long and fluid line of the flute can easily be identified as a moving body of water while the twittering of the piccolo, oboes and even the bassoon are imitative of bird sounds. (Ex. 3.9) Again when an army marches across the Hungarian plains, Faust points out their 'warlike sounds' and their 'song of victory. ${ }^{, 239}$ This immediately places the issue of phenomenal and noumenal music at the forefront of this work. We are constantly invited to listen and hear the same sounds that the characters themselves can hear. Not long after the chorus of peasants first sings, Faust asks, 'Quels sont ces cris? quel est ce bruit lointain?' [What are these cries? what is this distant noise?] ${ }^{240}$ Just like the audience, Faust can hear the music of the peasants. He then tells us that it is the peasants singing and dancing in the fields. This establishes the chorus singing as phenomenal music. This is further reinforced by the fact that the chorus are singing about shepherds - often the subject of idyllic village songs. When the music of this first chorus reverts to the first person and is conversational between the women and men, the chorus are not singing as themselves but in the character of shepherds

\footnotetext{
torments in Macbeth's mind. See Hudson, ‘...qualche cosa d'incredibile...': Hearing the Invisible in Macbeth'.

238 Berlioz, La damnation de Faust NBE, pp. 12-13.

239 'd'un éclat guerrier les campagnes se parent... leur chant de victoire', Ibid., p. 54-55.

240 Ibid., p. 35-36.
} 
and shepherdesses, which would suggest they also can 'hear' the music they are singing. It would seem that throughout the entire first part of Berlioz's score the only music that is noumenal is the music of Faust himself.

This trend continues on into the second part of La damnation de Faust. Faust is singing alone in his study. He suddenly hears an Easter Hymn. Again he invites the audience to listen, asking 'Qu'entends-je?' ['What do I hear?'] ${ }^{241}$ The chorus then sing their (phenomenal) Easter Hymn, while Faust describes his own thoughts and emotions over their singing. The music is thus both simultaneously phenomenal and noumenal. Berlioz seems careful to maintain this distinction with Faust describing this Easter Hymn as 'these songs', 'Sweet songs of heaven', 'hymns of prayer', and 'Songs sweeter than the dawn', reminding the audience that he is hearing these songs just as the audience is. ${ }^{242}$ When Mephistopheles suddenly appears he too describes the peals of the bells and the way in which these sounds have 'charmed' Faust's 'troubled ears' ${ }^{243}$ Mephistopheles makes this emphasis on hearing and listening explicit when he promises, 'j'enchanterai tes yeux et tes oreilles'. [I will enchant your eyes and your ears.' $]^{244}$ In this concert opera, the enchantment of Faust's eyes must come from our imaginations alone, yet the enchantment of his ears seems to be something that the audience can experience alongside Faust. This constant entreaty

\footnotetext{
241 Ibid., p. 87.

242 ces chants $[. .$.$] doux chants du ciel [. .$.$] Hymnes de la prière [. .$.$] Chants$ plus doux que l'aurore. Ibid., pp. 96, 107, 108.

${ }^{243}$ Les pieuses volées / De ces cloches d'argent /Ont charmé grandement /Tes Oreilles troublées! Ibid., p. 110.

244 Ibid., p. 112-113.
} 
for the audience to listen disturbingly places the two protagonists in almost self-conscious roles of creators and composers. $^{245}$

When Faust and Mephistopheles appear in Auerbach's cellar in Leipzig, Mephistopheles again describes the songs of his fellow drinkers. This is then followed by two comic diegetic songs from Brander and Mephistopheles, as well as a boisterous and mocking fugue from the male chorus. This fugue is worth some consideration. Brander calls out, 'Pour l'Amen une fugue! une fugue, un choral! Improvisons un morceau magistral!' ['A fugue for the Amen. A fugue, a chorale! /Let us improvise a masterpiece!'] ${ }^{246}$ Berlioz here is highlighting the artificiality of the music that follows. A fugue is a highly regulated form and usually associated with learned composers, yet as we have already seen in his Roméo et Juliette, Berlioz enjoys subverting the expectations and application of the 'serious' fugue. The fugue is usually an exercise in illustrating one's competence and excellence in composition and surely shouldn't be able to be improvised by a group of lecherous drunks! Berlioz is pointing towards the mechanics and structures of musical forms as a whole and perhaps highlighting their dramatic limitations. The fugue is a form that in Berlioz's opinion expresses no emotion or dramatic feeling at all and is instead employed to illustrate how any drunkard can apply musical rules. It would seem that Berlioz inherited this almost irrational hatred of fugues from his

\footnotetext{
245 This is ironic considering Mephistopheles is meant to be the 'spirit of negation'; Liszt had a very different approach to Mephistopheles in his Faust Symphony, giving him only parodies of others' music since he is unable to create his own; but Berlioz's libretto introduces him as 'the spirit of life'.

246 Berlioz, La damnation de Faust NBE, p. 144.
} 
teacher Le Sueur. Le Sueur himself stated emphatically 'fugues which express nothing, and whose only object is to display the composer's vain erudition and the solution of some problem [and which] should be banished from our churches... resembling as they do the labour of that legendary pea-stringer who threw peas from a distance on to the point of a needle...247 Is this a section where Berlioz is, to some extent trying to justify his own creation of dramatic music that is highly irregular and generically problematic? Is he showing his audience how artificial generic conventions have become?

Faust is not entertained by the comic songs of the drunken chorus or Mephistopheles and asks whether 'a quieter place' could not be found. ${ }^{248}$ Mephistopheles obliges, and soon Faust is being lulled to sleep with the songs of the Gnomes, Sylphs and Mephistopheles. Mephistopheles implores Faust, 'Écoute! écoute! Les esprits de la terre et de l'air /Commencent pour ton rêve un suave concert'. ['Listen! Listen! /The spirits of the earth and of the air /Start, for your dream, a sweet concert.'] ${ }^{249}$ The use of the term concert again reminds the audience of their own presence at a concert opera. When Berlioz awakes from his dream demanding to see Marguerite, Mephistopheles immediately transports Faust to her door, where Faust and the audience then hear the (phenomenal) songs of students and soldiers. It seems that it is at this point we move from the concert hall to the operatic theatre.

\footnotetext{
${ }^{247}$ Berlioz, The Memoirs of Hector Berlioz, p. 597.

${ }^{248}$ N'astu d'autres plaisirs, un séjour plus tranquille / A me donner. Berlioz, La damnation de Faust NBE, p. 166. (Italics mine)

249 Ibid., p. 171.
} 


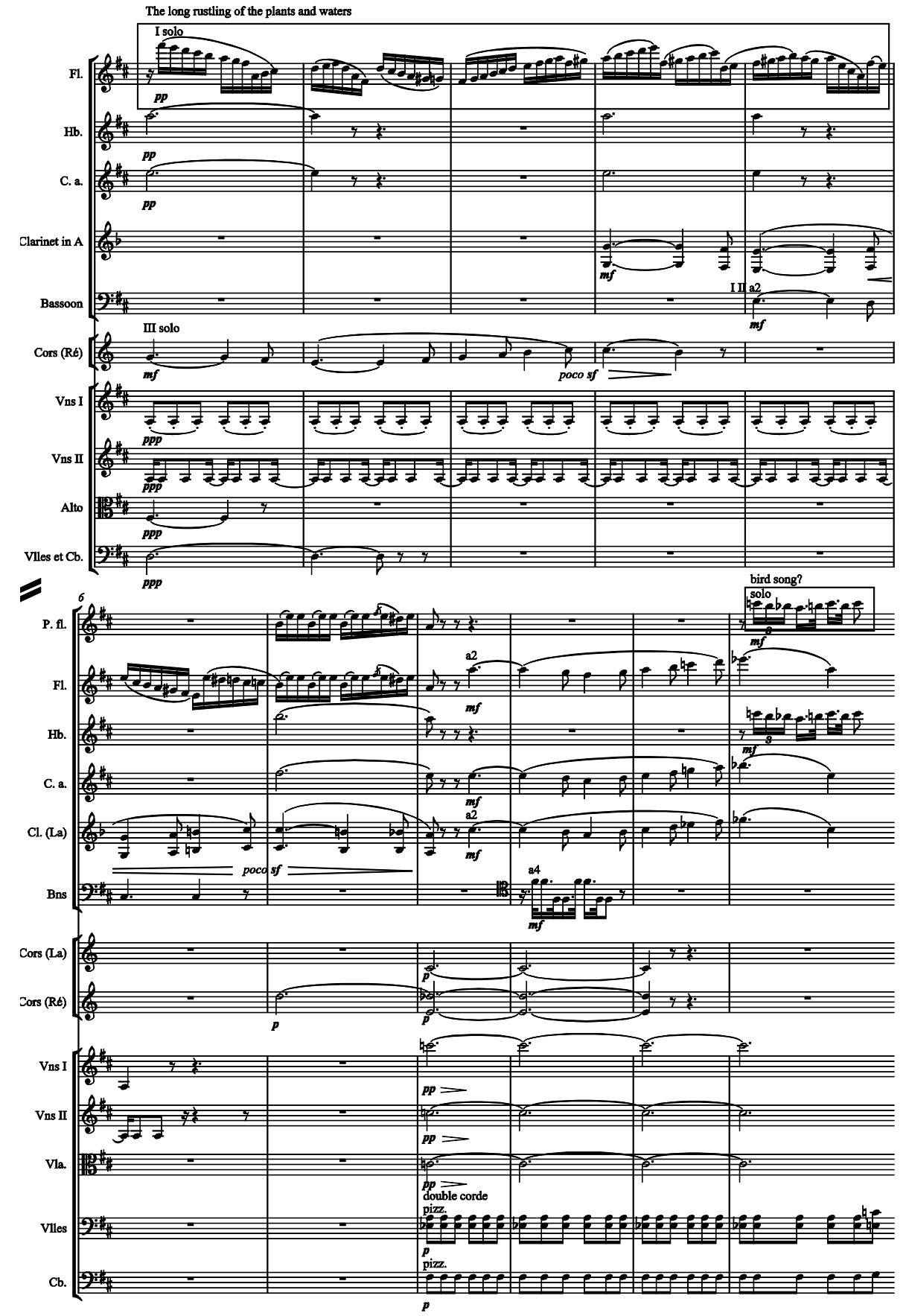

Example 3.9 Scène I, bars 83-93.

The phenomenal nature of the first two parts is replaced almost entirely by the noumenal music of Parts III and IV. The text no 
longer implores the audience to listen. Marguerite's medieval song is given no such introduction. Before Mephistopheles sings his phenomenal serenade, he again highlights the fact he is about to sing, yet this is the last such invitation to listen in the score. Interestingly there is a shift from an invitation to listen to a constant demand to be silent as the noumenal music of the score becomes dominant. When Faust and Marguerite sing their duet, Mephistopheles tells his spirits to be silent. When Faust sings his aria at the beginning of Part III he sings, 'Que j'aime ce silence'. [How I love this silence]. ${ }^{250}$ When Mephistopheles appears to tell Faust of Marguerite's fall from grace he is told, 'Tais-toi!' ['Hold your tongue!'.] ${ }^{251}$ Though there are still descriptions of sounds heard by the characters these sounds are no longer self-consciously made. They are the sounds of demonic horses flying, roaring forests and thunder and lightning. This shift in the singers' own consciousness as they inhabit their characters' narratives more completely, has the effect of making the separation between their singing bodies and dramatic actions more uncomfortable. As Marguerite and Faust sing their ardent duet, describing how they are overcome with ecstasies, the music and situation almost demands to be sung dramatically as opposed to the less personal and more direct addresses to the audience that characterized the first half of the libretto and score.

The fact that Faust is the only character in this work who does not sing any phenomenal music is highly relevant. The noumenal nature of his music is highlighted in a way similar to

\footnotetext{
250 Ibid., p. 254.

251 Ibid., p. 395.
} 
the phenomenal music of the other characters. As already stated above, when Faust sings his Air during the ninth scene, he describes how he loves 'this silence'. This almost seems a contradiction in terms considering this is one of the occasions where Berlioz has composed a truly dramatic and impressive aria. Within the conventions of opera, the aria is one of those rare moments where one could expect the audience to listen most intently, as the more 'realistic' nature of recitative is superseded by the melodic and more song-like aria. It is often at these moments that the 'sensuous' act of hearing again impedes. While singing this aria, Faust, like the audience, is actively hearing all the musical charms that the devil is employing to win his soul. The way in which his music is noumenal, (at no time does he sing a song for the audience), Faust can be seen as functioning almost as much as an audience member as the crowd that surrounds him. Berlioz's constant situating of Faust alongside the audience perhaps belies his own personal identification with Goethe's protagonist. Is Berlioz trying to create a similar feeling of identification between the audience and Faust to reflect his own connection with this character?

Within La damnation de Faust we are presented with a series of visual and musical riddles. On one hand Berlioz is an extremely picturesque composer, whose ability to create musical images was widely commented on within his own lifetime. Berlioz was compared with specific visual artists as well as bearing more general associations with the fine arts. On the other hand, as in Lélio and Roméo et Juliette, Berlioz decided to suppress the physical visual dimension in the performance of La damnation de Faust. Indeed, specific moments prove themselves to be unperformable. However, within all three of the compositions that 
have been considered in this study, Berlioz still seemingly flirts with the inclusion of, or allusion to, physical movement and visual representation. More importantly, this exploration of visuality has proven to bear significant implications in how we can read Berlioz's programmes. If this visuality does contain, in itself, narrative meanings, how then are these concepts changed when we do decide to perform Berlioz's works in a theatrical manner? In analysing two performances of La damnation de Faust, created more than one hundred years apart, we discover how both productions contain similar responses to the many questions of how one should stage this multi-faceted composition. Specifically, both productions use the best technologies available in an effort to capture the supernatural in Berlioz's score. In coming to terms with how directors have approached La damnation perhaps one can uncover something essential within Berlioz's narrative that can only be experienced within the concert hall, or within the theatre of the imagination. It is only through seeing what is created within a theatrical interpretation of this work that one can understand what has been lost in adding this visual dimension to the score. The very absence of animated bodies in concert performances, to some degree makes the drama of this story more real. If the character of Faust only exists in the temporal music, then when he dies, he quite literally dies. As in literature, a character whose only manifestation takes place within the pages of the book is contained by them and fated to live out the experience dictated from the page. A tenor performing the role of Faust, however, will step out at the end of the performance, take a bow, and reveal everything to be a pretence. Hence it is possible that what we witness aurally is something more sinister than anything we can experience visually. 


\section{RICHARD WAGNER, VICTOR HUGO AND HECTOR BERLIOZ}

One of the major problems with the term 'programme' music is the assumption that 'programme' simply means telling or narrating a story. It is therefore concrete and cannot convey any sense of the infinite and absolute. Yet while the large structure of La damnation de Faust may indeed tell Faust's story, Berlioz does not set out to narrate but rather to illuminate and give impressions, to perhaps touch upon the void as seen through the eyes of his characters. ${ }^{252}$ Victor Hugo's preface to Cromwell may best articulate what Berlioz and his contemporaries may have been trying to achieve:

We see on the stage only the elbows of the plot, so to speak; its hands are somewhere else. Instead of scenes we have narrative; instead of tableaux, descriptions. Solemn-faced characters, placed, as in the old chorus, between the drama and ourselves, tell us what is going on in the temple, in the palace, on the public square, until we are tempted many a time to call out to them: 'Indeed! Then take us there! It must be very entertaining - a fine sight!' to which they would reply no doubt: 'It is quite possible that it might entertain or interest you, but that isn't the question; we are the guardians of the dignity of the French Melpomene.' And there you are! $!^{253}$

Throughout the nineteenth century there can be felt a distinct sense of rupture between the audience and the performance; all art was felt to be filtered through these 'guardians of dignity', be they the music critics of the time, the patrons of the opera houses or in Berlioz's case the director of l'Opéra. Indeed Richard Wagner expressed a similar feeling of disjunction between audience and performance. Interestingly he saw Goethe's Faust as a prime example of how these ruptures can be easily

252 Rodgers, Form, Program, and Metaphor in the Music of Berlioz, pp. 21 22.

253 Victor Hugo, Théâtre: Les trois premiers actes de Cromwell (Paris: Librairie de L. Hachette et Cie, 1858), p. 24. Translation by Charles W. Eliot. 
felt and affect that impact of the work itself. Wagner believed that Goethe's Faust 'would be inconceivable at our modern semi-theatre, with its scenes presented to us merely on the flat, en face ${ }^{, 254}$ The story of Faust as seen through only one screen cannot surround and move listener. As Dieter Borchmeyer explains, Wagner was interested in the role of the listener as an active participant; 'a theatre which can rely on his imaginative agility of mind and which, as a result, has no need of illusionistic designs, since it is sufficient for the scene of action to be "meaningfully suggested". ${ }^{255}$ Interestingly Wagner felt that any appropriate staging of the Faust story would require the most current developments in technology alongside a less structured and divisive stage to be truly effective.

Though Hugo's preface was surely a manifesto for his fellow poets, similar sentiments were being articulated across the arts. Throughout the long nineteenth century the traditions and conventions that had ruled the arts were increasingly becoming subverted. This was a century of new forms and the integration of different forms into each other, and if composers of this century were to have their own formative manifesto it would surely lie in the symphonies of Beethoven. Beethoven's final symphony with its choral tour de force shook the foundations of both symphony and opera. Wagner is often credited, and credits himself, with inheriting this symphonic tradition and applying it to opera; with Wagner the orchestra within opera now had a voice. Yet Wagner's debt to Beethoven and his feelings towards his own music-dramas were an everchanging process. Wagner famously remarked that 'having created the

\footnotetext{
254 Richard Wagner, Richard Wagner's Prose Works: Volume 5 Actors and Singers, trans.
} William Ashton Ellis, (New York: Broude Brothers, 1966), p. 193.

255 Dieter Borchmeyer, Richard Wagner Theory and Theatre, trans. Stewart Spencer (Oxford: Clarendon Press, 1991), p. 44 
invisible orchestra, I now feel like inventing the invisible theatre'. ${ }^{256}$ That Beethoven's symphonies were often interpreted with a clear programme establishes a precedent of instrumental music having the capability of containing this idea of the 'invisible theatre'. ${ }^{257}$ Wagner's desire to build this invisible theatre can be seen to stem from his desire to abolish the gap between audience and performance and ultimately between composer and audience. It was this gap between audience and performers that the proscenium stage created that Wagner claimed impeded him from writing a Faust opera. As Wagner argued in his essay On Actors and Singers, "before that [proscenium] stage the spectator stays entirely withdrawn into himself, awaiting passively from there above, and finally from there behind, fantastical contrivances to bear him to a world from whose real midst he wishes to remain aloof. ${ }^{258}$ Wagner felt that a Faust, in order to truly capture the essence of Goethe's, would need to be performed on an Elizabethan stage capturing the improvisatory nature that exists between this stage and its audience. Wagner also felt that any true performance of Faust would also need to employ the latest technological advances within the theatre to recreate the magic and mischief of Mephistopheles. As we will see, the use of technology, when applied to Berlioz's score, seems to turn this work into a vehicle that becomes about technology. Berlioz's Damnation de Faust is clearly influenced by Hugo's call to arms. This work encapsulates an approach of communicating directly to the audience through music itself. Berlioz assumes his audience is already familiar with the events in the story and

256 Ibid., p. 46.

${ }^{257}$ See for example Berlioz's own analyses of Beethoven's symphonies in Hector Berlioz, A critical study of Beethoven's nine symphonies: with a few words on his trios and sonatas, a criticism of Fidelio, and an introductory essay on music trans. Edwin Evans (London: Scholarly Press, c.1958).

258 Wagner, Richard Wagner's Prose Works: Volume 5 Actors and Singers, trans. William Ashton Ellis, (New York: Broude Brothers, 1966), p. 193. 
instead concentrates his efforts on 'showing' his audience the sonorous images of Faust's story as he imagines them, unfettered by the physical layers of costumes, scenery, lighting and set. Though this may not have been his 'intention', Berlioz has created a work that can be seen to distort and change when visual elements are reintroduced to the work. Like an alchemist forever toiling, one finds that these base elements of costume and set cannot be changed into the gold of Berlioz's own score. Has Berlioz achieved Wagner's ideal - a sonorous theatre that surrounds the listener and transports him into Faust's realm? 


\section{Chapter Four: Raoul Gunsbourg and La damnation de Faust}

Throughout the twentieth and twenty-first century, various staged productions of La damnation de Faust have been mounted at all the major opera houses and in most cultural capitals including Paris, New York, London, Rome, Brussels, Cologne, Naples, Strasbourg, Chicago, Tokyo, Boston, Berlin, Philadelphia, Amsterdam, and Turin. Whether this is an 'authentic' approach or not, it is obvious that there is a long held practice of treating Berlioz's score as a theatrical work. So what happens when Berlioz's La damnation de Faust is staged as an opera proper? The work was first adapted and staged by Raoul Gunsbourg in 1893 for the Monte Carlo opera house. This same production travelled throughout the world including the Théâtre Sarah Bernhardt, l'Opéra, La Scala and the Metropolitan Opera, all before 1950. This particular production was frequently performed and had eminent and notable singers appear in the three major roles including Jean de Reszke, Nellie Melba, Francesco Tamagno and Geraldine Farrar to name just a few. ${ }^{259}$ With this in mind, when we return to Dahlhaus's claim that the visual replaces the textual in modern opera, is the visualisation of this originally non-theatrical work able to illuminate what modern audiences miss from a lack of intimacy with the original text? If this is the modern practice of being more reliant on visual narrative does this mean we are therefore more practised and able to imagine in a more visually rich manner? Does this have a significant impact on the meanings of

\footnotetext{
${ }^{259}$ Michael Scott, 'Raoul Gunsbourg and the Monte Carlo Opera' The Opera Quarterly, 3/4 (1985-1986) 74.
} 
this work for modern audiences, accepting that meanings and ideas are contingent and fluid?

The Romanian impresario and self-taught composer Raoul Gunsbourg embodies the essence of what an opera impresario should be. He was evidently charming, well connected and willing to fabricate things to ensure a stellar production. Perhaps one of his best attributes was his willingness to take risks and support artistic enterprises that wouldn't immediately guarantee success. It is no surprise then that having spent just one year in his new post as the director of the Monte-Carlo opera house, he decided to turn Berlioz's 'légende dramatique' into an opera. Gunsbourg became the director of the Monte-Carlo opera house in 1892 and remained at the helm until $1951 .^{260} \mathrm{His}$ adaptation of La damnation de Faust was not executed without questions from the media as to the appropriateness of such an act. When the production toured to Paris in May 1903, the centenary of Berlioz's birth, the practicalities of turning Berlioz's Faust into an opera were questioned. A preview from the periodical Le monde artiste informs the reader that Berlioz purposefully subtitled the work an 'Opéra de concert', and later a 'Légende dramatique'. ${ }^{261}$ He stated:

Légende dramatique...Opéra de Concert...Cela n'est-il pas significat? Et nulle part, ni dans les Mémoires, ni dans les lettres intimes de Berlioz, on ne trouve le regret qu'un scène lyrique ne s'empare pas de la Damnation de Faust. Partout au contraire Berlioz parle des exécutions symphoniques de son œuvre.

\footnotetext{
260 Ibid., p. 70.

261 Anonymous review, Le monde artiste, vol. V. (1 February 1903), 249-250.
} 
L'effort de M. Gunsbourg de vulgariser par le théâtre la partition que M Colonne a rendue populaire par le concert n'est point tout-fois pour nous déplaire. Mais nous exprimons le voeu que l'habile directeur rétablisse au Théâtre Sarah-Bernhardt les divisions voulues par l'auteur. Qu'il n'oublie pas que la première partie se passé dans les plaines de la Hongrie; et que c'est à la deuxième partie seulement que l'action se noue dans la Cabinet de Faust, dans le Nord de l'Allemagne.

La musique de Berlioz "excelle à peindre les bruits extérieurs, le tumulte des flots courroucés, la course échevelée des noires cavales à travers l'espace infini, le grincement des branches vertes tordues par la foudre". Berlioz est "un musicien coloriste" et l'on ne peut pas impunément faire passer dans un décor fermé ce qui'il a conçu et écrit pour les larges espaces. ${ }^{262}$

[Dramatic legend... Concert Opera... Isn't that significant? And nowhere, not in the Memoirs, nor in the personal letters of Berlioz, does one find any regret that The damnation of Faust wasn't taken up by the lyric stage. Above all, on the contrary, Berlioz spoke of symphonic executions of this work.

The efforts of Mr Gunsbourg to popularize, through the theatre, the score which Mr Colonne made popular in [the] concert [hall] isn't the only cause for our reservations. But we do express the wish that the skilled director restores to the Sarah Bernhardt theatre the divisions desired by the composer; and that he doesn't forget that the first part [of this score] takes place in the plains of Hungary; and that it is the second part alone where the action unfolds in Faust's study, in the north of Germany.

The music of Berlioz 'excels at painting noisy exteriors, the tumult of angry tides, the frenzied gallop of black horses which travel across infinite spaces, the wailing of green branches bent by lightning.' Berlioz is 'a musical colourist' and one can't, without impunity, move into the confines of a set that which was designed and written for open spaces.]

If Gunsbourg was to put on this work as an opera he would be advised to return the original parts that Berlioz left us. More

262 Ibid. pp. 249-250. 
than anything else, we should understand that Berlioz, above all else, is a symphonic colourist, a painter of sounds and effects, therefore his music is much better suited to infinite space rather than the closed décor of a theatre. Berlioz never intended this work to be performed as an opera, and, as far as this reviewer is concerned, Berlioz is better understood as a symphonic composer rather than an operatic one. Indeed many French critics of this time, due to both political tensions with Germany and perhaps through a little guilt, were careful to understand Berlioz as a great composer, but specifically a composer of symphonic music. ${ }^{263}$

Despite the hesitations and accusations of the press, Gunsbourg declared that he had veritable proof from Berlioz himself that this adaptation was a desired and necessary thing to do. Gunsbourg insisted that Berlioz indeed intended the work as an opera and produced a letter written by Berlioz to his son Louis which proved the fact. In this letter Berlioz states that he has written an opera on the Faust legend, but as no opera director will produce the work, he has resorted to putting it in a concert form. A fragment of this letter was printed in the programmes which were for sale at the premiere on the seventh of May 1903. ${ }^{264}$ Berlioz supposedly wrote:

Je viens d'écrire un opéra sur l'œuvre de l'immortel Goethe, je ne sais si je me suis approche dû géant, mais je sais qu'aucun directeur de théâtre ne voudra le monter

\footnotetext{
${ }^{263}$ Wright, 'Berlioz in the Fin-de-siècle Press', p. 167.

264 Richard Macnutt, 'Berlioz Forgeries' in Berlioz: Past, Present, Future ed. Peter Bloom (Suffolk: University of Rochester Press, 2003) pp P. 176.
} 
et que je serai hélas force de faire exécuter des parties en concert afin de pouvoir les entendre. ${ }^{265}$

I have written an opera based on the work of the immortal Goethe, I don't know if I size up to this giant, but I know that there isn't a theatre director who will want to put it on, thus I will be forced to put it on as a concert opera so it can, at least, be heard.]

The 'barely legible facsimile' itself was then published in subsequent programmes. ${ }^{266}$ Adolphe Jullien claimed in articles that appeared in the Journal des debats of the same year that this was certainly a fraudulent letter, especially considering that Berlioz would have been writing this rather business like letter to his son who was only thirteen when it was supposedly written. ${ }^{267}$ Nevertheless, regardless of the composer's own intentions or any hesitations critics may have had, the production went ahead and was a roaring success.

Though Gunsbourg's forged letter claimed that the work was already an opera, the impresario recognised that substantial changes needed to be made in order to translate La damnation de Faust onto the operatic stage. Gunsbourg's first act was to transform Berlioz's four parts into five acts. ${ }^{268}$ As we will see, the division into acts is not governed in relation to Berlioz's original score but instead chosen in relation to the many different locations in Berlioz's (and Goethe's) Faust.

\footnotetext{
265 Ibid., p. 192 n. 12.

266 Ibid., p. 176.

267 Ibid., p. 192 n. 12

268 Raoul Gunsbourg, Berlioz: La damnation de Faust, Mise-en-scène, (Paris: Costallat \& Co., c.1907). All subsequent details of this production are taken from this source.
} 


\begin{tabular}{|c|c|}
\hline Berlioz & Gunsbourg \\
\hline $\begin{array}{l}\text { Part } 1 \\
\text { Hungarian planes }\end{array}$ & $\begin{array}{l}\text { Act } 1 \\
\text { Act } 1 \text { Scene } 1 \text { Hungarian } \\
\text { Planes }\end{array}$ \\
\hline $\begin{array}{l}\text { Part } 2 \\
\text { Faust's study, } \\
\text { Northern Germany } \\
\text { Auerbach's Tavern in } \\
\text { Leipzig }\end{array}$ & $\begin{array}{l}\text { Act } 2 \\
\text { Scene } 1 \text { Faust's study } \\
\text { Scene } 2 \text { Auerbach's Tavern } \\
\text { in Leipzig }\end{array}$ \\
\hline Bank of the River Elbe & $\begin{array}{l}\text { Act } 3 \\
\text { Scene } 1 \text { A Valley of Roses }\end{array}$ \\
\hline $\begin{array}{l}\text { Chorus of soldiers and } \\
\text { students outside } \\
\text { Marguerite's house }\end{array}$ & $\begin{array}{l}\text { Act } 4 \\
\text { Act } 4 \text { scene } 1 \text { Marguerite's } \\
\text { room, town square and } \\
\text { entrance to the church }\end{array}$ \\
\hline $\begin{array}{l}\text { Part } 3 \\
\text { Outside Marguerite's } \\
\text { house } \\
\text { Inside her bedroom }\end{array}$ & Act 4 cont. \\
\hline $\begin{array}{l}\text { Part } 4 \\
\text { Marguerite's bedroom } \\
\text { Unspecified nature }\end{array}$ & $\begin{array}{l}\text { Act } 5 \\
\text { Scene } 1 \text { Marguerite's room } \\
\text { Scene } 2 \text { Rocky landscape } \\
\text { Cont. }\end{array}$ \\
\hline
\end{tabular}




\begin{tabular}{|l|l|}
\hline Ride to Hell past & Cont. \\
women and children & Scene 3 Heaven \\
Hell & \\
Heaven & \\
\hline
\end{tabular}

One of the benefits of writing a work without the intention of having it staged is the fact that the librettist and composer can change location or time as quickly and as frequently as desired. Berlioz certainly took advantage of this and his Faust and Mephistopheles travel through time and space with very little musical interlude if any at all - indeed changes of scene frequently happened in Berlioz's score within parts, and with very little transitory music between the different settings. As has been already noted, these changes in environment are stated in the text of the libretto but rarely mentioned or alluded to in the sung text at all. Yet because Berlioz assumed or required an intimacy with Goethe's Faust and provided a libretto to fill in his more ignorant audience members, he felt free to shift from Hungarian plain to Tavern to Hell as his inspiration fancied. James Haar agrees that Berlioz's La damnation de Faust, and, in fact, all of his operas were more episodic and fragmented than the operas composed by Berlioz's contemporaries. ${ }^{269}$ ) However, location is a more important issue when performing a narrative within a visual medium and quickly becomes a substantial problem for a theatre director. Raoul Gunsbourg has met these challenges in various different ways.

${ }^{269}$ Haar, 'The operas and the dramatic legend', p. 84. 
In Part One of Berlioz's score, (Gunsbourg's first act), Faust is first alone, then encounters singing peasants before hearing from a different plain a Hungarian military march. Gunsbourg begins his 'adaptation' of Berlioz's work with a set attempting to encompass all the different plains that Berlioz specifies for his opening scene. Gunsbourg has overcome the issue of Faust travelling from plain to plain by dividing his stage into three sections. There is a backdrop depicting 'the countryside'. ${ }^{270}$ To the left there is fortress that rises up to three meters, complete with parapets. On the right there is a group of soldiers erecting tents. From upstage there are three ramps that descend in a zigzag downstage and on each side are various groupings of trees and flowers. Thus Faust can travel down the ramp and see various different scenes and characters as he sings of them. Faust's movements in this scene are therefore not very problematic but his travels become more so as he journeys between countries, villages and divine realms.

The shift in space from Faust's study to Auerbach's tavern in Leipzig is visually more difficult to achieve. Gunsbourg describes in detail how this scene change works:

Derrière cette toile métallique, il y a un grand rideau noir qu'on monte pour laisser voir l'Eglise et qu'on redescend ensuit.

Derrière ce décor on doit planter la Taverne d'Auerbach, car ce changement se fait très rapidement, dans le noir et sans interruption à l'orchestre. On doit donc tenir tout prêts dans les coulisses les tables, les escabeaux, les brocs...Les artistes des Chœurs (hommes) doivent se première de leurs meubles et

\footnotetext{
270 'Rideau de fond représentant la campagne', Gunsbourg, Berlioz: La damnation de Faust, Mise-en-scène, p. 2.
} 
accessoires afin le placer aux mémés rapidement pendant le changement dans le noir. ${ }^{271}$

[Behind this wire gauze, there is a great black curtain which, when raised reveals the church, and which can fall afterwards. Behind this set Auerbach's Tavern can be placed, so this change can be very fast, in the dark and without interrupting the orchestra. One must then have all the tables, ladders, beer jugs etc waiting in the wings. The men of the chorus then must quickly take, first the furniture and then accessories to their places during the blackout.]

Though cleverly hiding the tavern behind the scenery of the church, allowing for a relatively quick scene change, Gunsbourg felt that this change could only happen convincingly with the help of a blackout. Even though, as Gunsbourg points out, the music itself does not stop, the visual narration must necessarily be broken to transport the audience to our new location lest the mechanisms of the theatre be exposed. Yet hidden within the blackout is a certain paradox. The darkness itself exposes the practicalities that must be hidden. Mephistopheles is suddenly not the creator Berlioz has imagined but an organic and earthbound creature governed by the limits of technology.

Gunsbourg also uses the help of a curtain to transport his characters from their drunken tavern in Leipzig to a 'valley of roses'. ${ }^{272}$ (Berlioz's score transports Faust to the banks of the river Elbe.) Gunsbourg has decided to end Act 2 with the conclusion of the tavern scene and begin Act 3 in a valley of roses, allowing for the curtain to come down, the set to be changed, and the curtain to rise in our new location. This is a much more disruptive visual break and is perhaps even more

\footnotetext{
${ }^{271}$ Gunsbourg, Berlioz; La damnation de Faust, Mise-en-scène, p. 8.

${ }^{272}$ Gunsbourg describes this scene as a 'vallée de roses', Gunsbourg, Berlioz;

La damnation de Faust, Mise-en-scène, p. 19.
} 
problematic as the score itself concludes the tavern scene before Faust expresses his disinterest in it. There is a very brief pause after Mephistophles's song of the flea, before Faust states that he finds all of this behaviour rather distasteful and asks to be shown something different. This short recitative is followed on immediately by 'travelling' music and we quickly find ourselves on the banks of the river Elbe, or in Gunsbourg's production 'a valley of roses.' Thus Gunsbourg would either have had to drop the curtain before Faust requests to leave the Tavern, or cause a break in the music that is quite jarring. (Ex. 4.1) Gunsbourg uses the same solution of the curtain drop and the insertion of a new act to transport Faust and Mephistopheles from their seductive valley of roses to the outside of Marguerite's house. Act 3 is thus comparatively short, taking only approximately fifteen minutes before the curtain falls. These sequences of short acts, continuously interrupting any musical continuity, are visually disruptive and perhaps serve only to emphasise the unusual structure of Berlioz's work. The constant fall of the curtain or dimming of the lights highlights the many different locations, emphasising visual narrative problems rather than the themes of the drama as a whole - the magical capabilities of our wonderfully gothic Mephistopheles. The act of trying to exhibit the different scenes within the work act to put the scene changes into the foreground, rather than the background, in which they resided in the libretto of the original score. The many different locations were not a problem in the concert version as our ethereal Faust and Mephistopheles figures could quickly and easily travel from space to space within our own imaginations, but the frequency of such locations, unevenly scattered throughout the score become a problem in a theatrical version. This transition into the theatre exposes events that were previously logistically unimportant but thematically and 
dramatically significant. One can see how Gunsbourg's structure of five acts has been governed not by dramatic impulse or effect but by logistical necessity. Logistical necessity surely never governed our Mephistopheles previously!

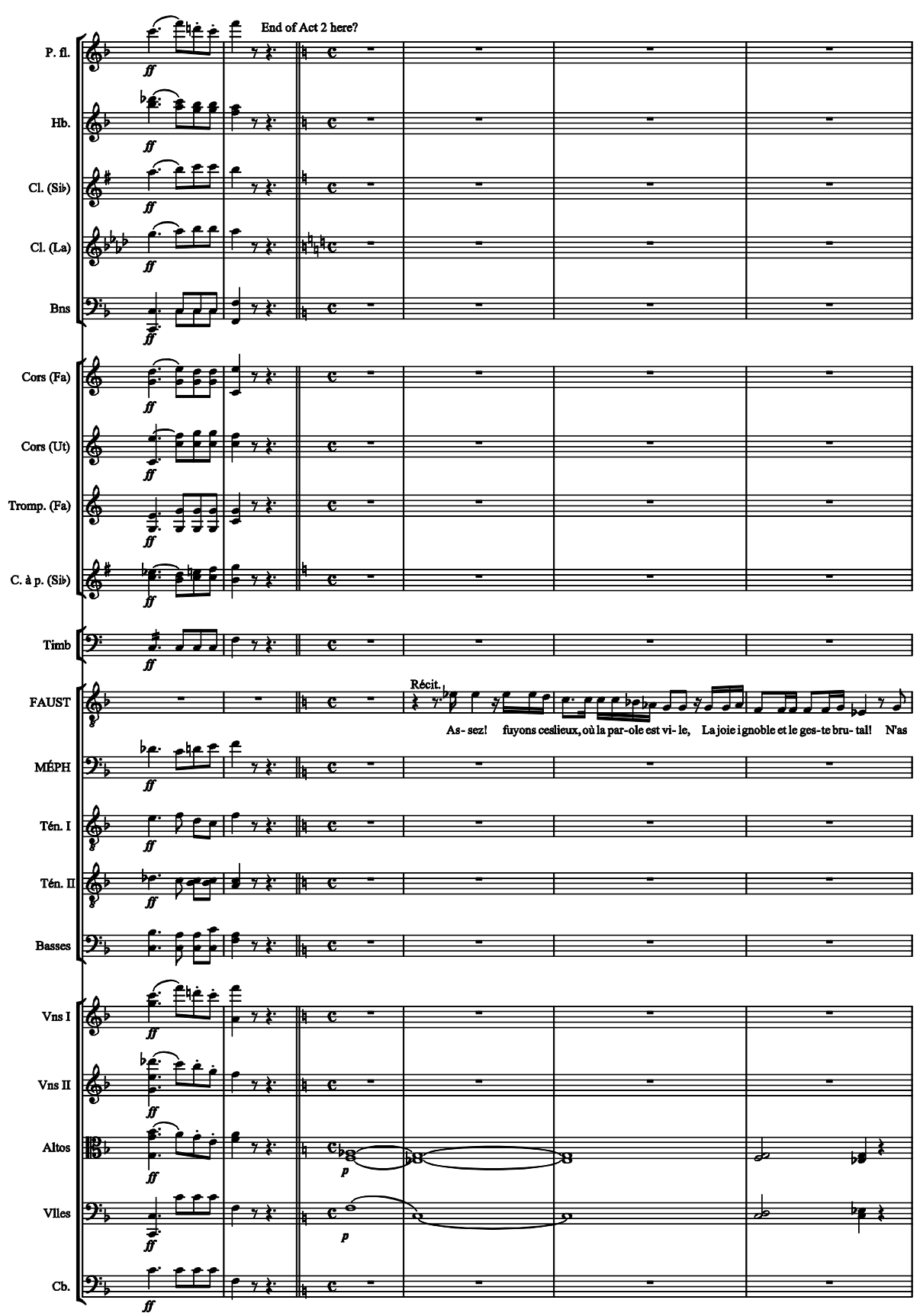



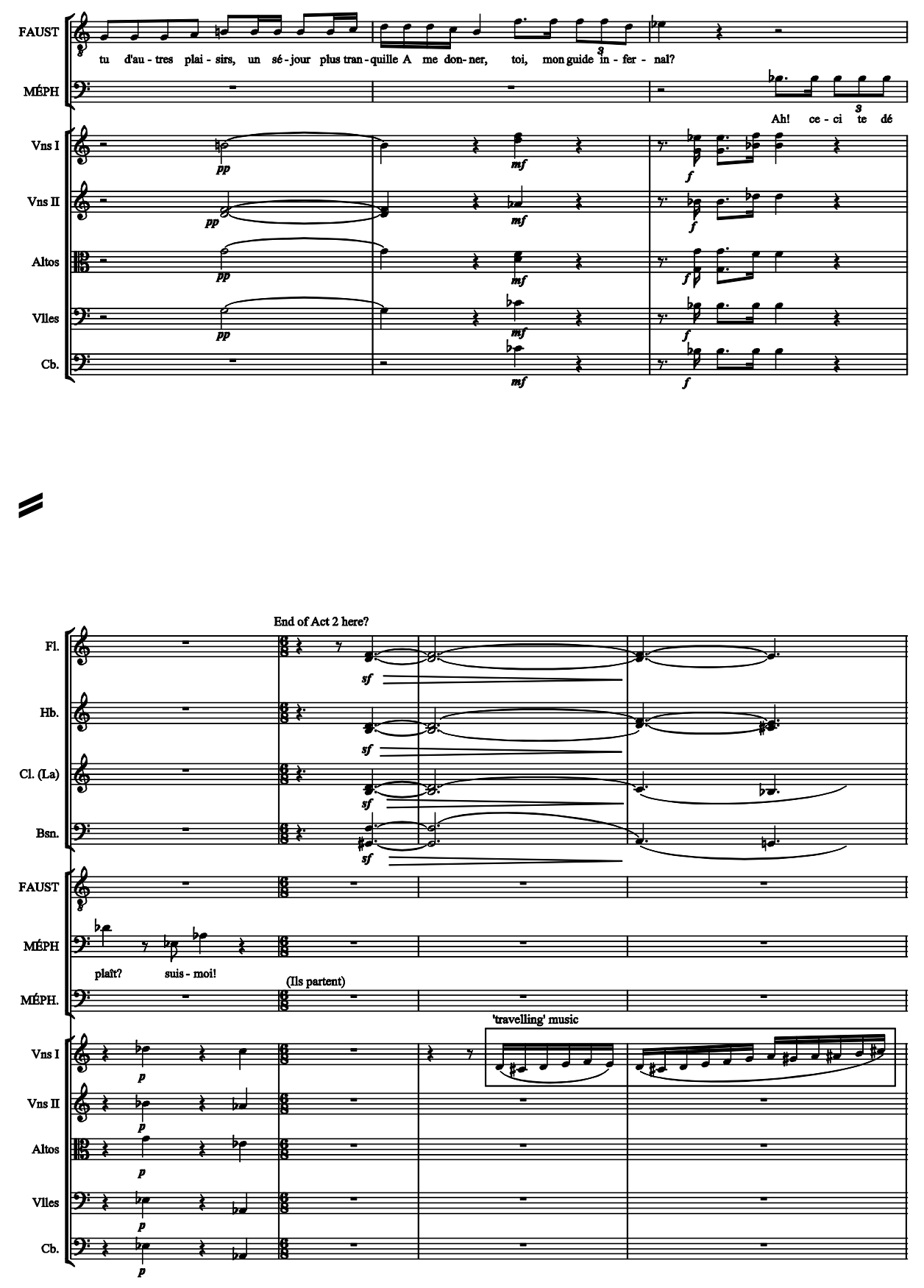

Example 4.1 'Chanson de Méphistophélès’ bars 80-92.

One of the advantages of adding a visual element to the performance of La damnation de Faust is the fact that movement, 
props and scenery can all be used to help tell and embellish aspects of Berlioz's narrative. This may be tempting for a director attempting to stage Berlioz's work, especially considering the fragmented and episodic nature of the Damnation. Berlioz did not attempt to tell Goethe's story in full, but rather chose scenes or events that appealed to him, assuming that his audience would already be familiar with Goethe's Faust legend. In Gunsbourg's adaptation we can see how he has decided to include other aspects of Goethe's story, perhaps in an attempt to create a more linear work or even a work that was more overtly operatic. One of his more comical choices was to revert back to Goethe's story in how he introduced the character of Mephistopheles. In Goethe's Faust, Mephistopheles inhabits the body of a black poodle and follows Faust into his study. Faust realises that the dog is possessed and demands that the devil show himself. He duly obliges, and Faust comes face to face with his destroyer. In Berlioz's version of the work, Mephistopheles simply appears ‘suddenly', interrupting Faust's suicide attempt. (Indeed it would be fairly difficult to try and suggest the metamorphosis from poodle to devil using music alone!) We know from the mise-en-scène that Gunsbourg reintroduces Goethe's concept of Mephistopheles turning from a black poodle into the devil incarnate. The description in Gunsbourg's second act, set in Faust's study, is detailed and specific. As was often the practice in the production of livrets de mise-en-scènes, Gunsbourg not only provides drawings of the set layout but he also labels each section. (See fig. 4) The shape labelled ' $\mathrm{F}$ ' is 'Un Chien Barbet endormi qui disparaitra a l'apparition de Méphistophélès. ${ }^{, 273}$ [A sleeping poodle which disappears when Mephistopheles appears.] The shape labelled

273. Ibid., p. 8 
' $\mathrm{E}$ ' is a chimney which, as the director has specified, must be big enough for Mephistopheles to enter through. ${ }^{274}$ This is a practical solution, obliging Berlioz's note about

Mephistopheles's sudden entry while also allowing the transformation of the poodle into Mephistopheles. One can imagine how this action would also suit Berlioz's music at this point in the score.

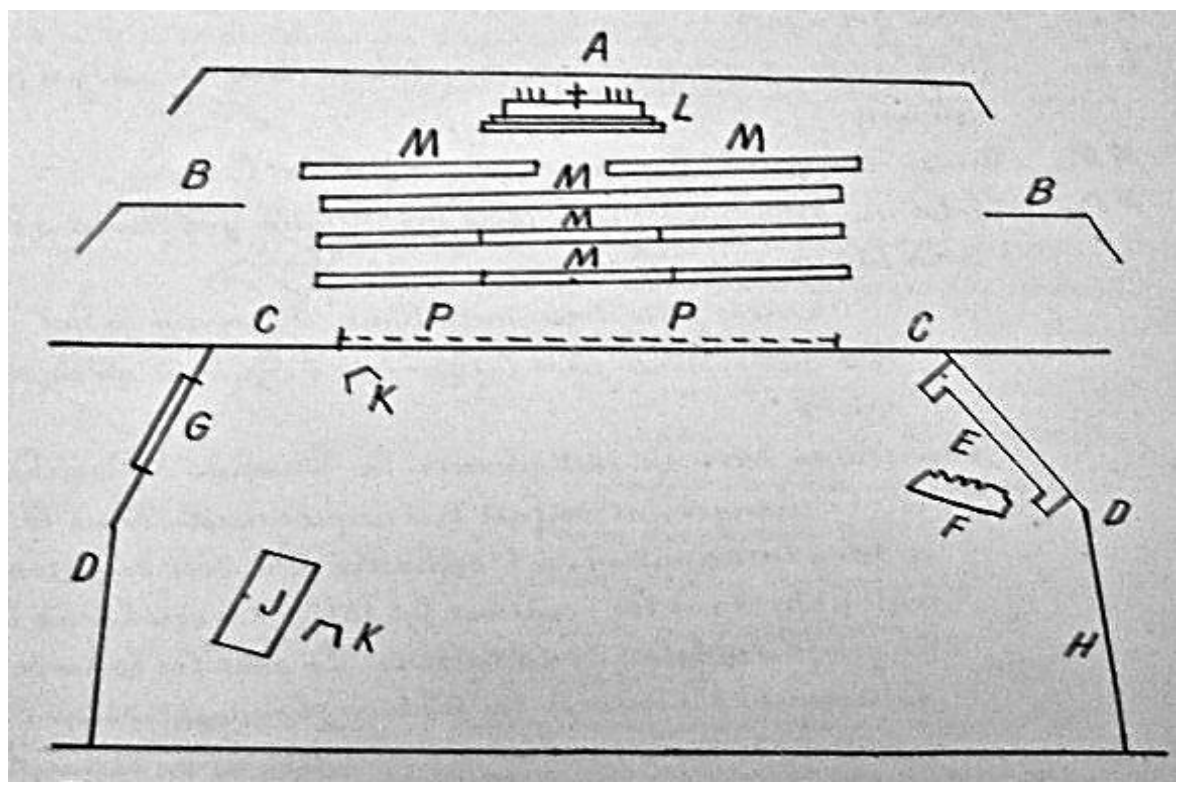

Figure 4. Gunsbourg's diagram of Faust's study.

There is a further note in the mise-en-scène where Gunsbourg states, 'On voit Méphistophélès accroupé à la place du chien. Il se dresse sur place pour “o pûre emotion”.'[‘One sees Mephistopheles crouching in the place of the dog. He stands in this place for his "O pure emotion".' $]^{275}$ Though this is a clever and entertaining way of introducing Mephistopheles to the audience, this switch between poodle and devil would only be recognised by those audience members who were familiar with

\footnotetext{
${ }^{274}$ Immense cheminée gothique, praticable par laquelle viendra Méphistophélès. Ibid. p. 8.

275 Ibid., p. 12.
} 
Goethe's legend and does not necessarily add anything to the sense of the story, though it may have a sense of operatic drama and buffoonery. This is an interesting point as one could reasonably assume that though Berlioz's audience may have been familiar with Goethe's Faust, (though Berlioz himself felt that audiences were not adequately acquainted with this literary masterpiece), it is more likely that Gunsbourg's audience would have been perhaps more familiar with Gounod's Faust.

Gounod's Faust was one of the most, if not the most popular opera of the nineteenth and early twentieth centuries. Gounod certainly doesn't immediately spring to mind when one considers Berlioz. However, though perhaps an odd coupling, Gounod and Berlioz do share some similarities. Gounod was Le Sueur's last pupil; Le Sueur was Berlioz's first music teacher in Paris. Gounod was also a fan of Shakespeare, composing an opera on Romeo and Juliet. Like Berlioz, Gounod was a Prix de Rome winner. Indeed it was while Gounod was in Italy, from 1839 to 1842 , that the composer, through Gerard de Nerval's translation, (the same translation that inspired Berlioz), decided to compose an opera on Gothe's Faust. Yet unlike Berlioz, Gounod did achieve the success at l'Opéra which Berlioz always craved. Gounod's five-act opera entitled Faust was first performed at the Théâtre Lyrique on 19 March 1859. It was an immediate success and was quickly performed in Strasbourg, Rouen and Bordeaux in $1860 .{ }^{276}$ German performances soon followed, though the work was renamed Margarete in an attempt

276 Steven Huebner. "Faust (ii)." In The New Grove Dictionary of Opera, edited by Stanley Sadie. Grove Music Online. Oxford Music Online, http://www.oxfordmusiconline.com/subscriber/article/grove/music/O901 567 (accessed August 6, 2009). 
to create a distance between Goethe's play and Gounod's opera. By 1863 Faust had been performed at La Scala and Her Majesty's Theatre. By the end of this decade Gounod's opera returned to Paris triumphant, culminating in performances at the prestigious Opéra, where it would become the most frequently performed work in the theatre's repertoire. Not only was Gounod's Faust popular, it became an important symbol of French nationalism, defining a French musical aesthetic in opposition to Wagner and his claims to musical supremacy. ${ }^{277}$ Gounod's Faust also played a crucial role in the early cinematizing of opera, an aspect which will be explored in a more detail below. ${ }^{278}$ Gounod's popularity has only waned post World War II.

There are instances where it is possible to see the influence of Gounod's opera in Gunsbourg's interpretation of Berlioz's work. Another aspect of Faust's character not made obvious in Berlioz's version of the story is the fact that Faust is a scholar and interested in alchemy. One can see how staging the work can easily reintroduce this aspect of Goethe's and Gounod's legend without disrupting Berlioz's music. Gunsbourg’s scrupulous notes give us a glimpse into how this aspect of Faust's character was made more explicit. Again, in his very detailed mise-en-scène there is a description of the things on Faust's desk. There is an hour-glass, piles of open books, crystals, flagons, an antique lamp as well as a skull with the

277 Ibid.

278 Rose Theresa, 'From Méphistophélès to Méliès: Spectacle and Narrative in Opera and Early Film' in ed. Jeongwon Joe and Rose Theresa Between Opera and Cinema (New York: Routledge, 2002) p. 1-18. 
'head facing the audience'. ${ }^{279}$ (See fig. 5) These props remind the audience that Faust is a scholar and an alchemist, even if the libretto and music do not emphasise these details or, in fact, mention them at all. Yet it is questionable as to whether this detail is really a return to Goethe's story or an allusion to Gounod's work. Gounod's opera starts in Faust's study. The curtain lifts, illuminating the protagonist, surrounded by the objects of learning that have filled his life. Indeed the mise-enscène from Gounod's Faust describes how his study is 'garni d'ustensiles d'alchimiste, fourneau, cornues, têtes fantastiques, fioles, cranes, etc.' [His study is furnished with objects of the alchemist, furnace, steel converter, fantastical heads, phials, skulls etc.] ${ }^{280}$ Sound familiar? Gounod's Faust is desperately unhappy and damns happiness, science, prayer, faith and wishes to take his own life. Gounod's protagonist is initially and primarily introduced as an aged unhappy scholar. That is the extent of his character before he is transformed into a younger man. In contrast Berlioz's Faust is presented as a man of unspecified age who is filled with an existential angst and whose only solace comes from nature. He is not aged and does not yearn for youth as Gounod's hero does. In using props to highlight Faust's position in life as a scholar and alchemist - the old dusty books perhaps reflecting Faust's old dusty life - is Gunsbourg trying to reposition Berlioz's Faust in line with Gounod's more familiar character and make him easier to understand and perhaps more appropriately operatic by unconscious association?

\footnotetext{
${ }^{279}$ Gunsbourg, Berlioz; La damnation de Faust, Mise-en-scène, p. 9.

${ }^{280}$ H. Robert Cohen, The original staging manuscripts for twelve Parisian operatic premieres, p. 101
} 


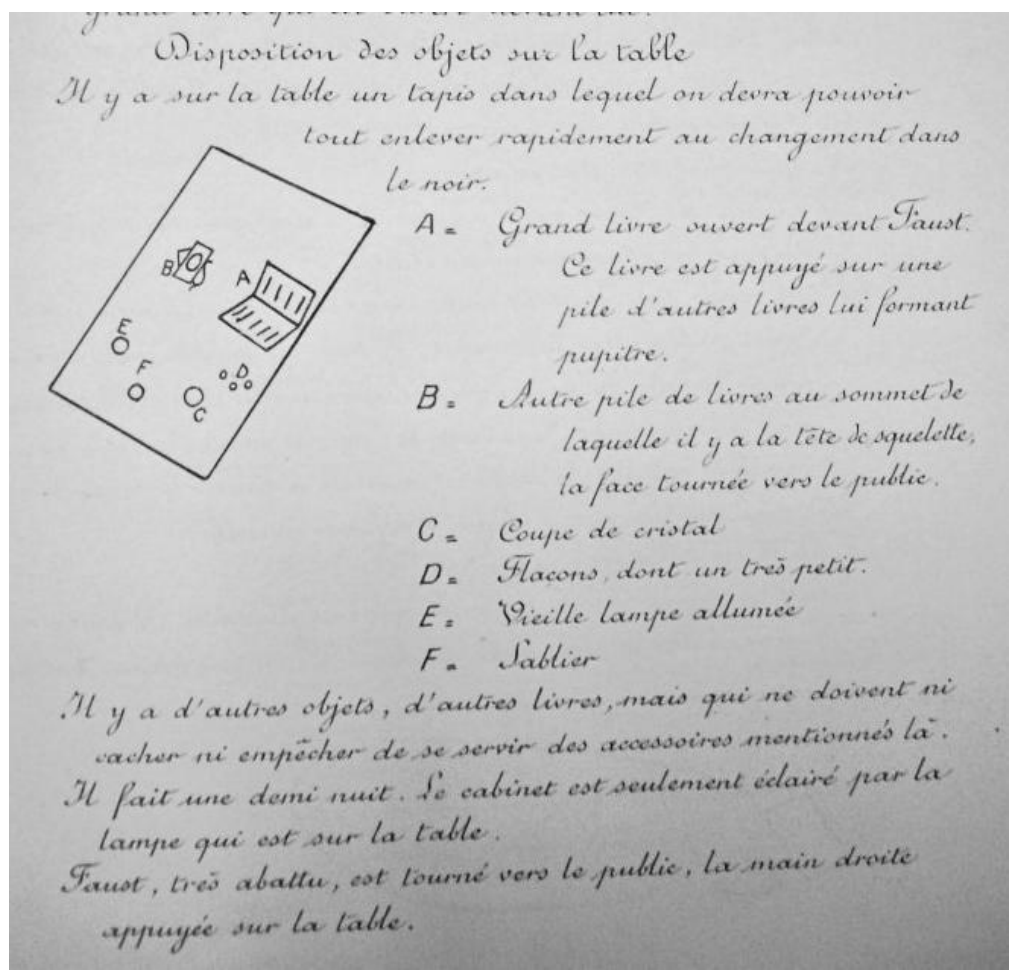

Figure 5. Gunsbourg's diagram detailing the props on Faust's desk.

Though this scene is perhaps a little ambiguous in its intent there are moments within Gunsbourg's mise-en-scène that more obviously allude to Gounod's Faust. Unsurprisingly these moments are found when Marguerite is on stage. Berlioz's treatment of Marguerite is decidedly un-operatic. She is on stage for only one third of the entire work; she has no dazzling Jewel song and her ascent to Heaven finds her mute. This is in stark contrast to Gounod's version. While Gunsbourg does not attempt to reintroduce a treasure of jewels, he does emphasise Marguerite's own divine struggle with the devil. After Marguerite has sung her (divine) 'Le roi de Thulé, Gunsbourg dictates a curious scene between herself and Mephistopheles. Marguerite appears on stage as if she is asleep or hallucinating; she is clearly being controlled by Mephistopheles. Three times she attempts to kneel in front of the church and pray but all 
three times she is unable to bring her hands together. Finally as she faces the church for the final time she sees an apparition of Faust, (created by placing Faust behind some metal gauze to give the appearance of a ghostly or dreamlike figure), and returns to her room to meet her mysterious lover. This action could have been created in order to make sense of a later line in which she states that she saw Faust in her dream - we, the audience, have just seen this take place. Yet this sequence of events is also very reminiscent of a scene from Gounod's Faust. In scene three, act four of Gounod's opera, Marguerite goes to the church to pray, yet Mephistopheles is there and whispers in her ear of her damnation, preventing her from finding the solace she seeks. Though this scene can also be found in Goethe, both Gounod and Gunsbourg have Mephistopheles haunt Marguerite's thoughts, whereas in Goethe it is simply an evil spirit that disturbs her. As before, this mimed scene does not necessarily add to the narrative. Instead it does serve to mirror Gounod's well-known opera and by its reflection lend Gunsbourg's adaptation a sense of operatic practice and convention.

Though Gunsbourg's adaptation can be seen to have been influenced by Gounod's immensely popular opera, Berlioz's score is undeniably dramatic in ways that are unique to Berlioz alone. One of the most potent scenes within Berlioz's work, and perhaps the most difficult to portray visually, is the 'Course à l'abîme'. Interestingly, though the work as a whole encompasses many different settings, this is the only scene which is dedicated to the act of travelling itself. Previously Faust and Mephistopheles have simply appeared and disappeared at whim. This ride to Hell is a conscious act, desperately consented to by 
Faust. Though Berlioz believed he may have been able to stage this scene in London, it would seem that Berlioz has inadvertently created a scene that would perhaps be close to impossible to portray literally for any director short of using the most modern technologies. Faust and Mephistopheles ride two demonic black horses, and as they gallop towards the inferno, Faust narrates the horrifying creatures that he encounters. When they come across a group of praying woman and children they simply trample them. Re-creating this scene in 1893 would have taken a feat of imagination, and it seems that Gunsbourg, in describing his own approach to this scene, is proud of his solutions. Needless to say that having two galloping horses on stage is not an advisable nor in fact a probable option. Instead, when Faust agrees to sign away his soul, the devil and protagonist seem to disappear. They are instructed to sing their remaining music from behind onstage scenery. The theatre grows dark and a simulated storm begins. Rain falls while forks of lightning shudder across the stage. Instead of having horses stomp through praying children and women, the cross they are kneeling towards is struck by lightning and they scatter in fear. When Faust describes the monstrous birds and beasts that he sees, a panorama is used to show these various images. 
Sa contse a l'abinse commence.

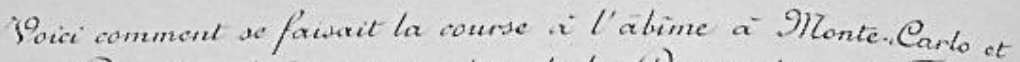

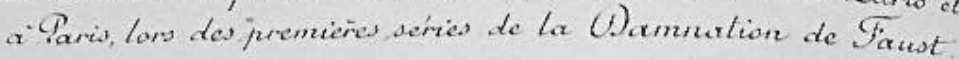

Aussitor que los formes et les enfornts sont surtis la pluie tombe. isici oomment:

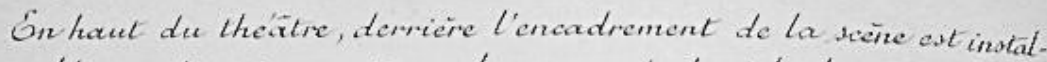
lé un reiservoir ayant une longueur égale a la largeur du cadre.

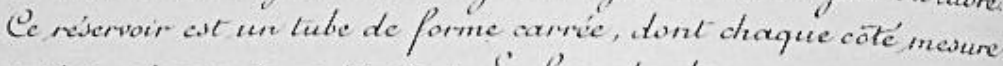

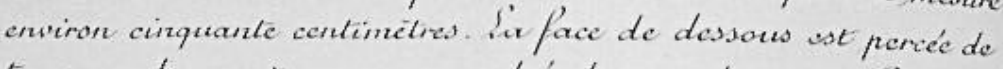

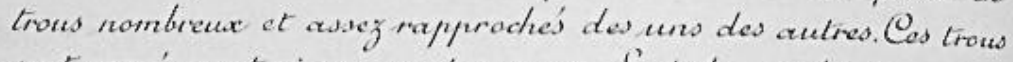
sont percés sur trow on quatio rangs. ic tube cot légèrement

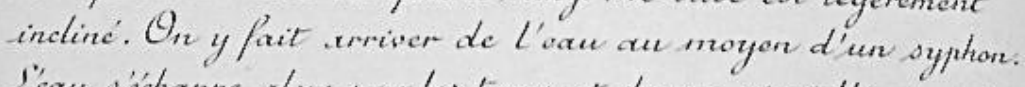

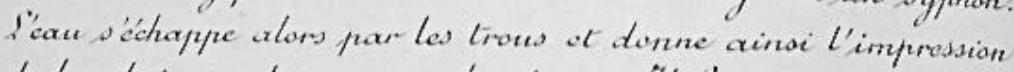
de la pluic tombant awee abondance. Hl faut pouroir ameter l'oaw a volonté en fermant le robinet du syphon.

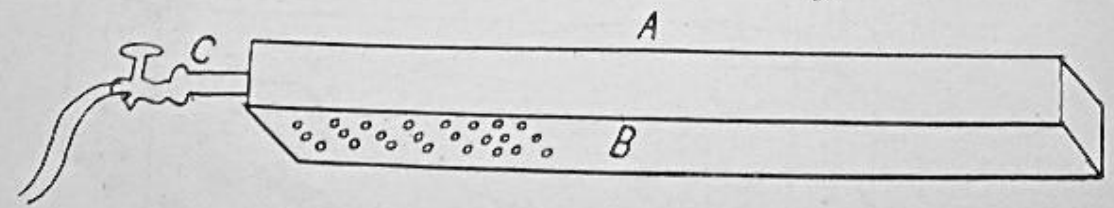

A. Gube pour l'can

B. Tace du dessons prercée de trous par lesquels doit s'óchapper
l'eau

o- Syptoon, robinet, tuyau ameruant l'cau dars le tube.

Figure 6. Gunsbourg's Livret de mise-en-scène p. 54. 


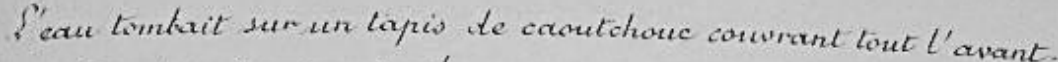

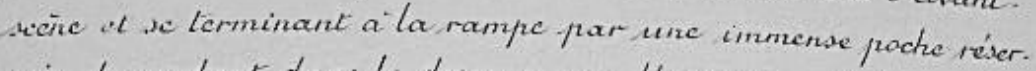

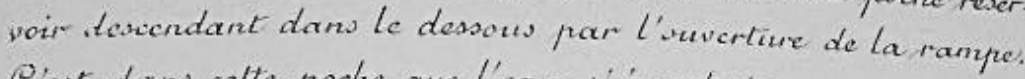
elest dewns celte poche que l'caw s'ejardait.

$Q_{12}$ a due renoncer a cet efful. S'cam, en tombant, fixivait beaucoup de bruit, malgre le tapis de cooutchrue, et ce brueit empechait d'enterdre l'orchostre. S'effer lui. mème n'était pas merpilleux. Pendant que la pluie tombe. Le ciel est sillonné d'édairs. (O) enterd au laintain le sourd grondement du tonnerte.

Puis on net on mouvement teux panoramas se développantau jardin et traversant la scene pour aller s'enrouler a la cour. Es panoramas sont équipes sur denx immenses cylindres places an 3-et au ts plans. Its sont transparents, et sus chacure d'eux sont peints tes Larves, des prectres, ses aiseaux de nuit, des wrbres, des rochers, des flammes des êtres étranges. Eout ceci est d'un aspect effrayant, inferinal, chadique. St comme les deux panoramas marchent it une vitesse differente, les sujets représentés de contrarient et orat l'air de se heurter. de se culluter.

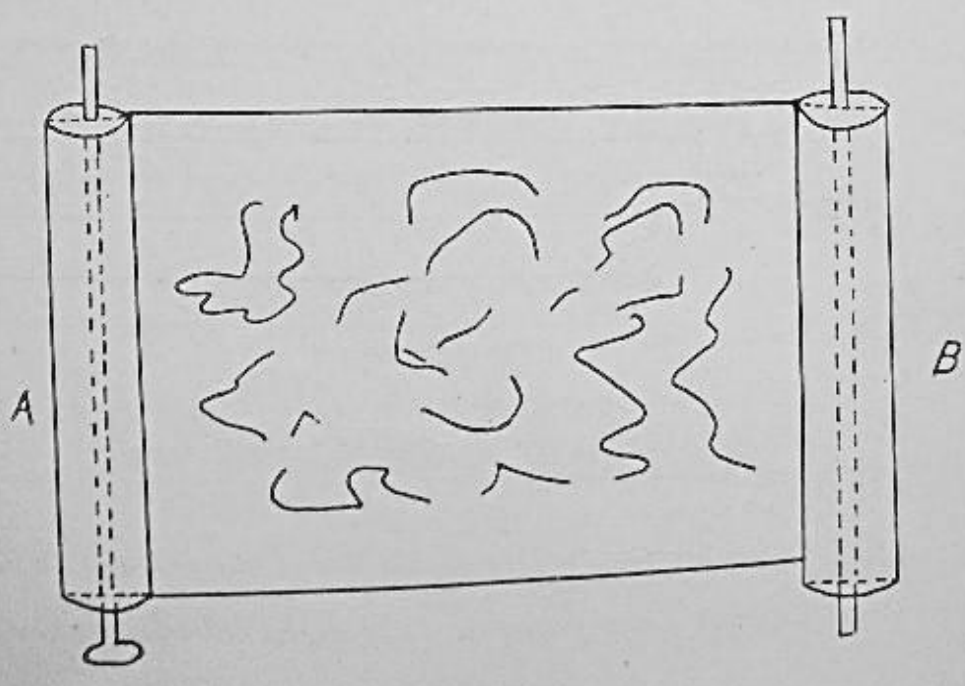

Figure 7. Gunsbourg's Livret de de mise-en-scène p. 55. 
The presence of these diagrams within the mise-en-scène highlights a major aspect of this production. Gunsbourg included these very detailed pictures of the machines he was using because he was proud of them and they were obviously a point of interest. We can imagine that Berlioz himself would have been more than impressed with the technologies employed in this production. If one considers that Der Freischütz, and its later French version Robin du bois, was considered to be quite advanced technologically for first employing the use of gauze in scenery and props to both hide and reveal ghostly characters, one can see how stage mechanics had come a long way since Berlioz's time. ${ }^{281}$ La prophète of 1850 was revolutionary in first employing the use of electric lights to create the effect of the sun. ${ }^{282}$ The use of a panorama that is so important in the climax of this production was first employed at Bayreuth for the premiere of Parsifal in 1882, only ten years before Gunsbourg's production was first staged. ${ }^{283}$ Gunsbourg's Damnation, considered within its own contexts, was certainly a technologically ground-breaking event. Though he perhaps couldn't have two satanic horses madly gallop about on the stage, Gunsbourg created something that would at least try and match the incredible sense of drama and spectacle that is contained in Berlioz's music.

\footnotetext{
${ }^{281}$ E. Douglas Bomberger, 'The Neues Schauspielhaus in Berlin and the Premiere of Carl Maria von Weber's Der Freischütr' in Opera in context: Essays on historical staging from the late Renaissance to the time of Puccini ed. Mark A. Radice, (Portland: Amadeus, 1998), p. 164

282 Pendle and Wilkins 'Paradise Found: The Salle le Peletier and French Grand Opera’ p. 199.

283 Evan Baker, 'Richard Wagner and His Search for the Ideal Theatrical Place' in Opera in context: Essays on historical staging from the late Renaissance to the time of Puccini ed. Mark A. Radice, (Portland: Amadeus, 1998), p. 270.
} 
Indeed Gunsbourg's production was a huge success, becoming a staple of the Monte Carlo Opéra's repertory until its close in 1949. It first appearance in Paris was at the Sarah Berndhart Théâtre and this same production was even put on, seven years later, at l'Opéra. Reading reviews of this production, it would seem that Gunsbourg's adaptation was successful for two reasons. Firstly, its various incarnations attracted magnificent cast members and secondly it contained the most up to date and modern stage technologies. ${ }^{284}$ This venture was also an undeniable financial success - the eighteen performances at l'Opéra made a sum total of 192,652 francs. ${ }^{285}$ Though a success with audiences, this production was not without criticism. A review of Gunsbourg's production at l'Opéra, published in Le Figaro on 11 June 1910, alludes to the many criticisms directed at Monsieur Gunsbourg for even daring to develop this concert work into a theatrical performance in the first place. ${ }^{286}$ This reviewer states a pertinent or perhaps rather cynical fact: yes it might have been more appropriate to see a Berlioz opera staged at l'Opéra such as Benvenuto Cellini or Les Troyens, but these have only been met with mediocre success in the past, whereas $L a$ damnation de Faust is the undeniable hit of the season.

Il est hors de doute qu'il serait préférable - au point de vue supérieur - de voir figurer sur les affiches le nom de Berlioz sous le titre des Troyens ou sous celui de Benvenuto; mais Les Troyens et surtout Benvenuto

\footnotetext{
284 According to the The Times, Madame Calvé gave up a position at the Opera-Comique and had to pay a fine of 30,000 francs, so she could sing Marguerite for the Parisian premiere of this production. Mr Alvarez also abandoned an American tour in order to sing the role of Faust. See Anonymous, "The "Damnation de Faust", The Times, 11 May 1903.

285 Wright, 'Berlioz in the Fin-de-siècle Press' p. 171n. 53.

286 Robert Bruesel, 'Académie nationale de musique: La damnation de Faust, légende dramatique d'Hector Berlioz, adaptée à la scène par M. Raoul Gunsbourg' Le Figaro, 11 June 1910, p. 5.
} 
n'attireraient peut-être que très médiocrement le public, tandis que la Damnation est et sera une grandes attractions de la saison. C'est une raison pour la défense; il en est d'autres. ${ }^{287}$

It is beyond doubt that it would be preferable - from a superior point of view - to see Berlioz's name featuring on fliers beneath the title 'The Trojans' or 'Benvenuto'; but 'The Trojans' and above all 'Benvenuto' would likely draw the public very poorly at best, while 'Damnation' is and will continue to be one of the great attractions of the season. This is one reason in its defence; there are others.]

Robert Brussel states that Gunsbourg is perhaps the most qualified to take on this precarious task of turning the concert opera La damnation de Faust into opera proper, especially given his ingeniousness and staging experience as the director of the Monte Carlo Opera. It would seem that the experience of modern stage technologies was an absolute requirement if one was to take on this supernatural work. Bruesel then goes on to list both the scenes that were naturally suitable to the operatic stage and the scenes that were more problematic:

Aussi bien n'est-ce pas une œuvre inédite qu'a montée l'Opéra et n'en faut-il considérer que la réalisation. $\mathrm{Ni}$ Faust seul dans son officine, ni la marche hongroise, ni la taverne d'Auerbach, ni la chambre de Marguerite, ni l'invocation à la nature ne pouvaient présenter d'obstacle à la représentation et l'Opéra a mis de la meilleure manière ces épisodes à la scène. Quant au ballet des sylphes, à la course à l'abîme, au Pandaemonium, les talents et les habiletés combinés des plus adroits techniciens n'auraient sans doute pas réussi à les représenter 'en vérité' ; aussi bien faut-il goûter la réserve qu'a mise l'Opéra à nous en suggérer l'image plastique. L'irréalisable appelle un minimum de précision. $^{288}$

\footnotetext{
${ }^{287}$ Ibid., p. 5.

${ }^{288}$ Ibid., p. 5.
} 
[As well, it is not an unheard-of work that L'Opera has staged, where only the production requires

consideration. Neither Faust alone in his dispensary, nor the Hungarian march, nor the Tavern in Auerbach, nor Marguerite's chamber, nor the Invocation to Nature could present any obstacle in their production, and L'Opera has staged these episodes in the best manner. When it comes to the Dance of the sylphs, the Ride to the abyss, and Pandaemonium, the talents and combined skills of the most adept technicians would undoubtedly have failed to represent these realistically; as well one must appreciate the reserve with which L'Opera has suggested to us the artistic image. The impossible calls for a minimum of detail.]

That these particular scenes to this critic, at least, were not able to be produced realistically is interesting. The reviewer states that these scenes are simply unrealisable, perhaps they are just not suitable for the stage? Berlioz's London 'machinists' may have had more trouble than he had foreseen. Or perhaps, twentieth-century audiences were less willing to suspend disbelief in the theatre when film was making the realisation of these images more possible?

Gunsbourg's production was an international one, touring throughout Europe. The premiere of this production on Thursday 8 May 1903 at the Théâtre Sarah Bernhardt was obviously such a momentous occasion it was even reviewed in the British publication The Times. (The reviewer likes to point out that this production had already been staged at Covent Garden.) After first lauding the excellent 'dramatis personae' of this production, he then goes on to state that:

The mounting of the opera, too, has been the object of exceptional care. It has been entrusted to M. Cranich, of the Beyreuth Theatre, who was responsible under Wagner for the remarkable scenery and mechanical effects of the Nibelungen Ring. It is thus apparent that 
great efforts have been made to furnish an adequate setting to the Faust legend and to the romantic music of Berlioz. ${ }^{289}$

It would seem from this comment that only the most experienced of producers, who have already proven themselves capable of producing 'remarkable scenery and mechanical effects' could put on $\mathrm{Mr}$ Gunsbourg's work. What is obvious from comments such as this is that the advanced technologies of this production are not only necessary but of significance. An audience member is not only going to notice the singing but also all the contraptions that try to create the many magical 'effects' within Berlioz's La damnation de Faust - the technology is a crucial element of the production and is discussed and commented upon in its own right. The work becomes a work about technology, that showcases technology, and, arguably, loses its meaning through the primacy of technology. In the concert version of Berlioz's La damnation de Faust, Faust and Mephistopheles are unshackled by physical restrictions and are thus able to do anything - they can travel from tavern to riverbed in a moment; Faust has sylphs dance above him in the air; they can ride on horse back past heinous monsters to the fiery pits of hell itself. The music and libretto of Berlioz's La damnation de Faust prove themselves to be quite specific in their rendering of these events. However, these events do not and cannot happen in Gunsbourg's adaptation; instead the audience notices feats of technology - the rain on stage, flashes of lights that resemble lightening. The seams of the magic itself are not only made obvious but later discussed for their effectiveness. As Theodor Adorno, commenting on the works of Richard Wagner, observed, '[c]ompared with seeing, hearing is "archaic" and has lagged behind technology. It could be said that to react with the unselfconscious ear rather than with the nimble, appraising eye is somehow in contradiction to the advancedindustrial era... The eye is always the organ of effort, work, concentration; it apprehends something specific in an umambiguous way.

289 Anonymous, 'The "Damnation de Faust", The Times, 11 May 1903. 
The ear, in contrast, is unconcentrated and passive. ${ }^{290}$ In other words, the ear is more likely to believe the fantastical apparitions of Berlioz's music than the eye will believe the technological feats of Gunsbourg. On a metaphysical level, the transformation of this score from a work of imagination to a work of reality, from its absence of physicality to its present physicality, destroys the power of Mephistopheles completely and instead our Faust cannot be damned nor our Marguerite saved. When the music of Berlioz stops so too does his damned Faust die. Gunsbourg's Faust on the other hand inhabits a body that will live on and present himself to the audience for his curtain call.

290 Theodor W. Adorno, In Search of Wagner, trans Rodney Livingstone, (Great Britain: Redwood Burn Ltd, 1981), pp 99 - 100 


\section{Chapter Five: Robert Lepage and La damnation de Faust}

\section{A CINEMATIC APPROACH: BERLIOZ'S ARTWORK OF THE FUTURE?}

That La damnation de Faust, in its first visual manifestation, became a showcase of modern theatrical mechanics would be of no more than a passing interest if this trend didn't seem to be a rather constant preoccupation in the staging of Berlioz's légende dramatic. It would seem that the possibility of the new is something that has always been employed when putting on productions of this colourful work. Gunsbourg's version of $L a$ damnation de Faust is filled with various technologies in order to try and seduce the audience. Perhaps the advent of new technologies made these unrealisable scenes more possible to perform on the live stage? A perusal of the Avant-scène dedicated to Berlioz's Damnation is filled with many more images of avantgarde productions than examples of more conventional stagings. ${ }^{291}$

291 Gérard Condé, 'Commentaire musical et littéraire' L'avant-scène opera Vol. 22 Hector Berlioz La damnation de Faust, ed. Gérard Condé (Paris: Éditions Premières Loges, 1995) Vol. 22, p. 50. 


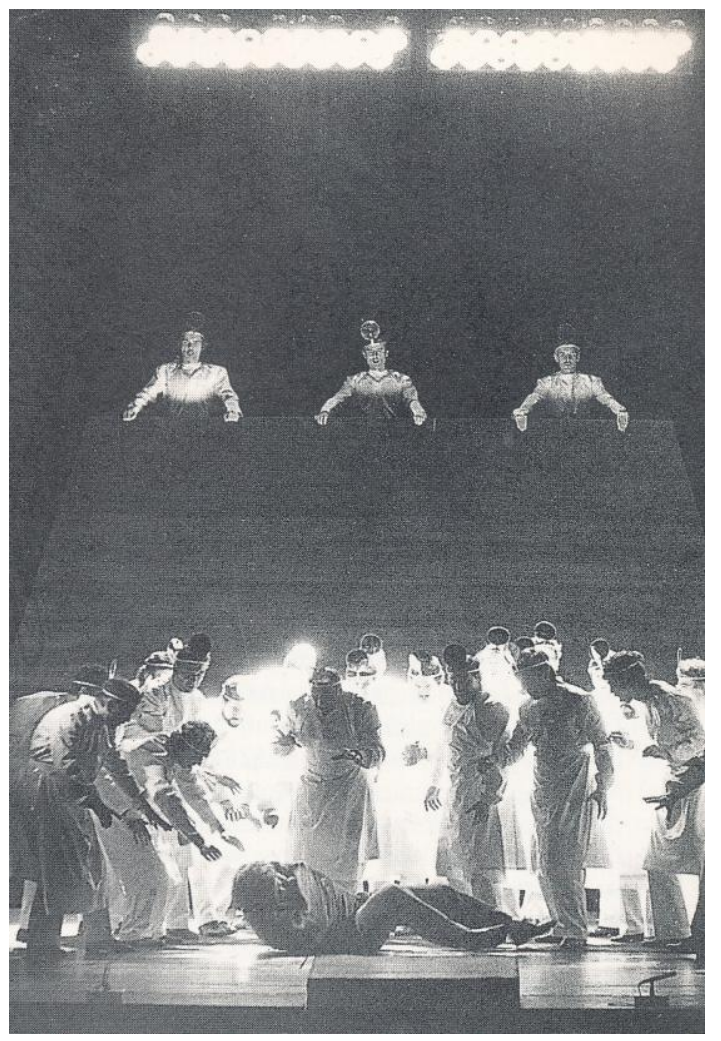

Figure 8. As Faust enters Hell he is attacked by a group of evil surgeons.

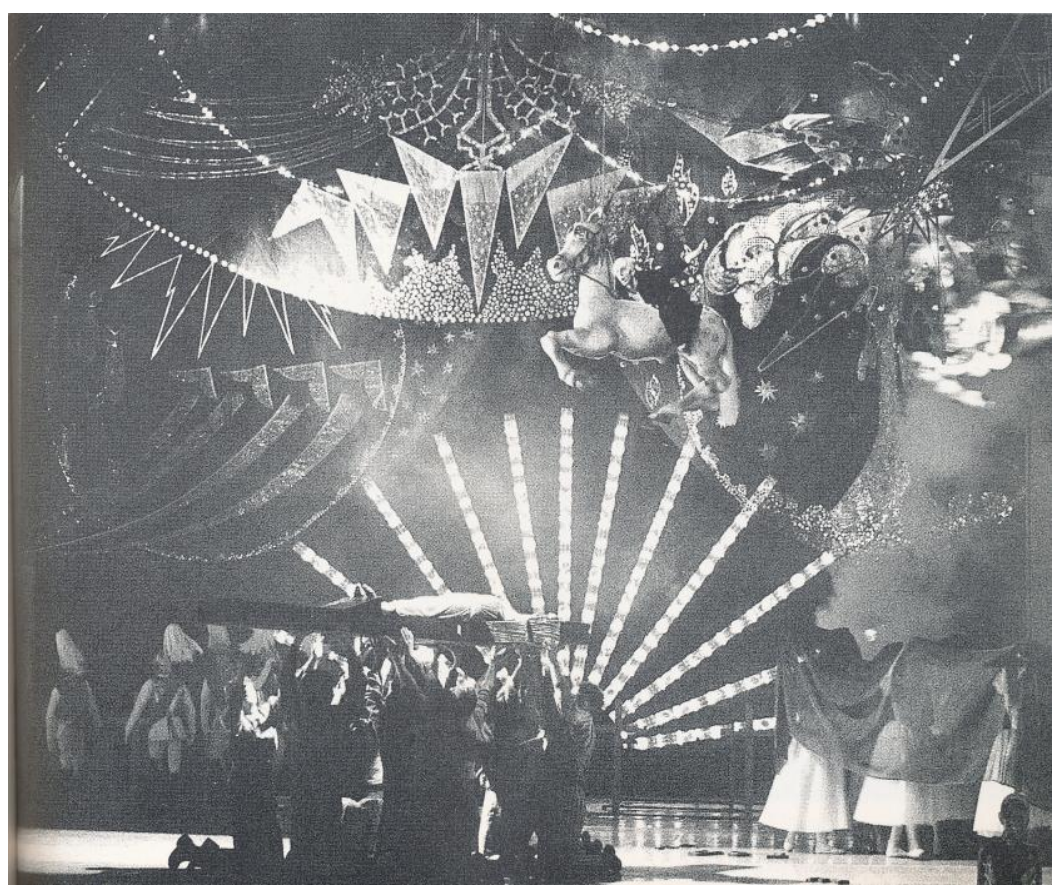

Figure 9. A production inspired by a twisted carnival. 


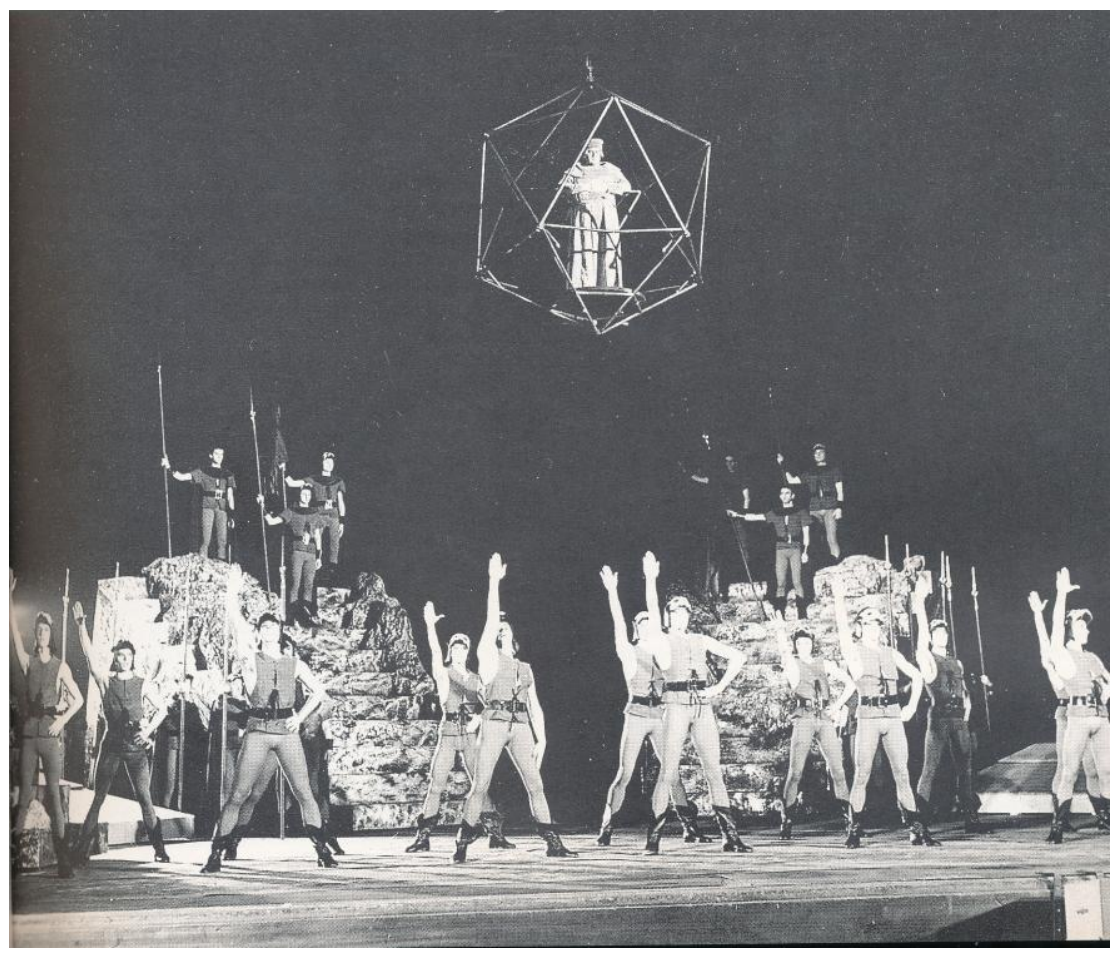

Figure 10. All hail Hector Berlioz!

Within Berlioz scholarship there seems a recurring tendency to suggest that Berlioz was writing music for the future - quite literally. Like James Haar, Julian Rushton, and Katherine Kolb, David Cairns also dismisses the idea that La damnation de Faust was really intended for the stage. He writes that:

[La damnation de Faust is an opera of the mind's eye performed on an ideal stage of imagination, hardly realizable within a framework of live drama. We see it more vividly than any external visual medium could possibly depict it, except the cinema (which Berlioz seems at times to be anticipating). ${ }^{292}$

The strikingly visual nature of this vibrant and exhilarating score, it is suggested, could be adequately performed with our own modern cinematic technologies. Berlioz certainly embraced new technologies - he was champion of the new instruments invented by his friend Adolph Sax and was very proud to have

${ }^{292}$ Cairns, Servitude and Greatness, p. 357 (Italics mine) 
anticipated the advent of the electric metronome for example and Berlioz does seem to have thought that modern technologies could perhaps enable his concert work to be translated onto the stage. When planning to stage the work in London, Berlioz was not concerned with the fact the score, at various times, contained scenes in which Faust and Mephistopheles are required to fly through the air or gallop into hell. Berlioz seemed to think that the operatic 'machinistes' in London would be equal to the task. ${ }^{293}$ Though the French term 'machiniste' simply translates as stagehand it is more than tempting to consider Berlioz meant something a little more exciting. This consideration isn't entirely implausible considering that l'Opéra was known to have a stable of at least sixty 'machinistes' for its performances. When Berlioz thought that the London stage hands would be up to the task of transforming concert opera into grand spectacle, was he assuring Scribe that such a task force could be obtained in this highly industrialised city as well? This story does seem to suggest that Berlioz was at least open to new technologies being used to help make this score more suitable for the operatic stage.

\section{ROBERT LEPAGE}

The idea of the futurist Berlioz is perpetrated in his supposed last words. It is claimed that with his last breath he uttered 'They are finally going to play my music'. ${ }^{294}$ Did he have an epiphany where he peered into the space-time continuum and

\footnotetext{
${ }^{293}$ Haar, 'The operas and the dramatic legend' p. 89.

${ }^{294}$ Cairns, Servitude and Greatness, p. 773.
} 
saw how future generations, with modern technologies, would be able to understand and appreciate his music? This final statement was probably a prime example of the composer's wit and cynicism. It is Berlioz seen as a 'futurist' figure that helps tie his music to a fellow 'visionary' - director Robert Lepage. As an interview in the American publication Opera News suggests, "The foreknowledge that a receptive marketplace would exist in our day for visionary theatrical work might have been a comfort to Hector Berlioz' ${ }^{295}$ Like Cairns, this journalist states that the ideal venue for this music is undoubtedly the theatre of the mind, but with the powers of Robert Lepage, Berlioz would be pleased to know, his masterpiece can be visually experienced by all and adapted successfully onto the technological, cinematic stage.

The Canadian born actor and director Robert Lepage is one of the most acclaimed theatre practitioners of our time. His award wining shows, notably The Dragon's Trilogy, The Seven Streams of the River Ota and The Far side of the Moon have travelled the globe and won him international accolades. His works are modern experimental pieces that challenge and surprise audiences, and like many contemporary directors Lepage has a wide field of experience directing films, live theatre, opera, rock concert tours and even a permanent Cirque du Soleil show in Las Vegas. He describes the theatre 'as a meeting place for architecture, music, dance, literature, acrobatics, play and so on. In all my shows this is what interests me most of all. ${ }^{, 296}$ An interview with BBC

\footnotetext{
295 August Ventura, 'Dreamcatcher' in Opera News 73/4 (2008), 22.

${ }^{296}$ Ibid., p. 22.
} 
reporter John Tusa in 2005 goes a long way in explaining the ethos behind Lepage's approach to theatre. Lepage feels:

Theatre cannot survive on itself if it doesn't take into account all the different narrative languages that are around $[. .$. The current generation] have a different narrative education than we have had [...] They're being told stories through rock videos and commercials in a way that we never had access to twenty or thirty years ago. People know what a jump-cut is, what a flashforward is, they know what a completely discursive montage can be, so I think you have to embrace all of these narrative rules and try to impose them [on] the theatre [...The] simplicity of theatre versus the very complex technology of 'canned' storytelling like [...] cinema or television or radio [...] has to merge and meet, the same way opera in the nineteenth century allowed all the different disciplines around to merge and meet and learn from each other [...] That's my interest right now - to be as theatrical as I can, but at the same time to embrace and use the tools of other storytelling technologies. ${ }^{297}$

His 2008 production of La Damnation de Faust is certainly representative of this mélange of various different forms of story telling. ${ }^{298}$ I would argue that what Lepage has created is a hybrid form of cinema performed live on stage. What happens when this hybridity is combined with Berlioz's own eclectic and fragmented composition?

\section{A MEETING POINT BETWEEN CINEMA AND THE THEATRE}

It is the opening night of the 2008 season of La damnation de

Faust. The curtain rises in the Metropolitan Opera house and

\footnotetext{
${ }^{297}$ Quoted in Ibid., p. 22.

${ }^{298}$ Lepage created this production of La damnation de Faust in 1999, though in the intervening ten years the production has gone through a metamorphoses evolving and incorporating many new technologies including projections that can respond instantly to the movements of the live actors, dancers, acrobats and singers on stage.
} 
the audience encounters an old man standing in front of a large, four level, scaffold-like construction. The four levels appear to be quite narrow in depth, leaving only enough room for a few players to move comfortably past each other at any one time. Throughout the production this scaffold is variously hung with multiple crucified Jesus figures; soldiers defying gravity, marching horizontally up and down the scaffold face; and devilish figures weaving up and down the various levels stealing the innocence of the white clad women they encounter. At other times this scaffold becomes an actual screen projecting images of water with a boat gliding through it; the tenor is shown swimming; and the diva sings with her own image enlarged and projected on the screen behind her which saturates both diva and stage in a sensuous red. Interestingly, even when images are not being projected onto it, the effect of this large four-storied construction, positioned relatively far downstage thus severely shortening the depth of the stage itself, gives the impression of the action taking place on a kind of threedimensional screen. The minimal depth of the scaffold itself, making it physically impossible to create any depth of massed bodies, reinstates the idea of a screen with its two-dimensional nature. Thus in a very post-modern twist, Lepage has created a stage filled with two screens, an actual screen and a physical three-dimensional recreation of a screen. What is more, this is taking place on a stage, which is framed around a proscenium $\operatorname{arch!}$

The multiplicity of planes acts to subvert the nature and capabilities of the screen itself. The singers and dancers move freely on and off this scaffold/screen at various times for dramatic and thematic effect. Yet the action of singers, dancers, 
and acrobats moving on and off this three-dimensional screen defies and questions the very nature of the cinematic screen itself. What is contained within the two-dimensional scope of a screen is suddenly broken when characters climb down onto the stage or literally leap out into the air. Susan Graham stands before us in all reality as her projected image is thus exposed as fake and unreal. Lepage has created a work that is both cinematic in scope while destroying the two-dimensional plane within which cinema must be contained. The discussion of cinema within opera, dramatized within this production, unveils and comments on the many issues that can arise when opera meets cinema. The very question of the possibilities and limitations that the screen can afford, which Lepage has explored in this production of La damnation de Faust, also mirrors the nature in which Berlioz's score explores the relationship between a narrative musical text and the nature of opera and theatre.

There is a longstanding historical relationship between opera and film - opera is closely tied to the birth of cinema itself. ${ }^{299}$ Yet, it is not surprising that the translation of one medium into the other should present ideological difficulties. It is inevitable that the relationship between opera and cinema must challenge and change the very meanings of both art forms. It seems almost incongruous that silent film should have anything to do with the performance of opera, yet opera was a salient subject in many silent movies. Michal Grover-Friedlander puts forth the idea that the very nature of silent film, 'it's fascination with and anxiety about silence is uniquely suited to revealing opera's

\footnotetext{
299 Theresa, 'From Méphistophélès to Méliès: Spectacle and Narrative in Opera and Early Film', p. 1.
} 
tendency to go beyond song $[\ldots]$ disintegrating into the cry, or into silence. ${ }^{300}$ Grover-Friedlander is suggesting that silent film and opera are both primarily concerned with the silence of voice rather than silence altogether. As many feminist readings of opera reveal, it is not until the virtuosity of the soprano is contained by silence - either by death or marriage - that order can be achieved. ${ }^{301}$ Thus throughout opera it is inevitably silence that is the goal. Grover-Friedlander goes on to illustrate how the adoption of opera by silent film changed the nature of opera entirely. When operas were re-created as cinema, the stereotypical operatic gestures and plot were kept the same. In some cases even the scenery and costumes were unchanged from what one would have seen on the stage. It was really only the human voice that was missing. ${ }^{302}$ Grover-Friedlander explains that this created an understanding that voices could be seen rather than heard and the meaning remain intelligible. Thus opera 'became an example of independence from language. ${ }^{303} \mathrm{It}$ is how Grover-Friedlander then expands upon this idea that may be revealing in what it shares with Berlioz's own practices. Grover-Friedlander states that the silent film expressed in a definitive way how opera went beyond the human voice itself, 'operatic singing derives its force...from its pointing to the limits of vocal expression, to the limits of meaning,, 304 If the

\footnotetext{
300 Michal Grover-Friedlander, “'There Ain't No Sanity Clause!”: The Marx Brothers at the Opera' in Between Opera and Cinema ed. Jeongwon Joe and Rose Theresa (New York: Routledge, 2002) p. 22.

301 Catherine Clément famously exposed the precarious nature of women within opera, inspiring and influencing the development of many feminist readings of opera. See Catherine Clément, Opera or The Undoing of Women trans. Betsy Wing (Minneapolis: University of Minnesota Press, 1988).

302 Grover-Friedlander, “'There Ain’t No Sanity Clause!”: The Marx Brothers at the Opera' p. 20.

303 Ibid.
} 
human voice can be separated from meaning and the physical bodies that contextualise and enforce that meaning, is that not also similar to what Berlioz was trying to achieve in Lélio, Roméo et Juliette and La damnation de Faust? Berlioz positions the singers as akin to instruments creating sound, but the system of narrative meaning is located within the greater whole of the entire ensemble. The voice itself can only express so much - yet there are other forms of expression that can communicate with an audience. The very generic peculiarity of Berlioz's dramatic concert works are an acknowledgement that the voice alone may not be able to communicate every aspect of psychological and dramatic meaning.

The most popular adaptation from opera to the silent screen was Gounod's Faust. Rose Theresa makes some suggestions as to why early filmmakers were so attracted to this particular opera:

Was it this gendering of visual pleasure in Gounod's Faust that appealed to early filmmakers? I would say yes, but it was more than that, too. For the visual and narrative dynamic provided by the two main characters is generated by a third one, namely, Méphistophélès. From within the diegetic world of opera, he conjures male and female spectacle out of thin air. With a wave of his hand, she appears. If Faust can look, it is because Méphistophélès makes it so. Here and elsewhere throughout the opera, it is through this trickery that spectacle and narrative are combined. Méphistophélès, in other words, embodies a fantasy of mastery over technology - the stage, settings, lighting, and even the orchestra - that realizes the opera in performance. Méphistophélès's fictive control over the operatic apparatus was perhaps the ultimate pleasure that Gounod's Faust had to offer its spectators, and

304 Ibid., p. 22. 
especially the cinematographers who made his opera their own. ${ }^{305}$

I would argue that in fact it is not Gounod's opera that was so attractive to cinematographers, but Goethe's Faust, or perhaps more simply the story of Faust itself, that was ideal for explorations of the new and exciting technology of cinema. It just happened that Gounod's composition was particularly popular at this moment in history. As Theresa claims, it is the dominating and exciting figure of Méphistophélès that drives the narrative and conjures the magic in the story. Cinema can offer a sense of reality to the story of Faust that is perhaps more difficult to achieve in the theatre. In cinema people can take flight, Marguerite can actually appear before one's eyes and rise from the dead. The magic of the movies can make magic more possible than ever before.

History has shown how cinema is 'attracted' to opera and in some ways enhances certain aspects of the operatic medium through the silver screen. Conversely the positioning of a screen in live performance can offer up different meanings and problems for the audience. This issue as well as others have been explored in a collection of essays entitled Between Opera and Cinema, edited by Jeongwon Joe and Rose Theresa. ${ }^{306} \mathrm{It}$ is the various questions that the relationship between cinema and opera pose that I would like to explore in an analysis of Robert Lepage's production of La damnation de Faust.

\footnotetext{
305 Rose Theresa, 'From Méphistophélès to Méliès: Spectacle and Narrative in Opera and Early Film', p. 5.

${ }^{306}$ Jeongwon Joe and Rose Theresa, Between Opera and Cinema (New York: Routledge, 2002).
} 
Jeongwon Joe, in his study of Philip Glass's Beauty and the Beast, has written a fascinating account of the implications a cinema screen can have on a live performance. ${ }^{307}$ Joe distills the difference between cinema and opera down to a central issue of the realism of the cinema and the antirealism of opera as defined by the very act of singing itself. In Philip Glass's Beauty and the Beast, the composer has set his score to a previously 'complete' artwork. Glass took Cocteau's film, Beauty and the Beast, erased all of the audio sound and replaced it with his own music, treating the script as an opera libretto and recomposing the film as opera. In performance the movie is projected onto a screen while the singer, 'becomes an instrument', and gives sound to the words being formed on screen. ${ }^{308}$ As Joe points out, Glass has subverted the usual understanding of cinematic reality and operatic fantasy. Glass's Beauty and the Beast highlights one of the major illusions of cinema itself. Sound and picture are necessarily separated through screen and speaker. Their union is effectively an illusion. That cinema is built on illusion, 'the magic of the movies', and yet strives to depict reality can be seen as a particularly Faustian conundrum. What further complicates matters when considering La damnation is that Berlioz himself has already questioned the realism of the singing voice. His decision to write a 'légende dramatique' as opposed to an opera proper illustrates a concern with the very definition of opera itself. Berlioz had already called the realities and possibilities of opera into question, creating a more realistic psychological drama taking place within one's imagination - this is perhaps partly why modern commentators think his work is

${ }^{307}$ Jeongwon Joe, 'The Cinematic Body in the Operatic Theatre: Philip Glass's La belle et la Bête' in Between Opera and Cinema ed. Jeongwon Joe and Rose Theresa (New York: Routledge, 2002), pp. 59-73.

308 Ibid., p. 64. 
so suited to the cinematic screen. When Lepage questions the very nature of the cinema screen in his production, one of the major terrors of Faust can be explored - the nature of reality itself, and whether we may in fact prefer a life of illusion.

While Joe exposes the illusion of cinema, Grover-Friedlander explores how cinema's possibilities highlight opera's absurdities. ${ }^{309}$ Yet when enacting the unrealism of opera on the screen, it is the screen itself that reveals itself to be false and absurd. As Grover-Friedlander states:

A closer look at these scenes [from the movie $A$ Night at the Opera] reveals that parody stems from a deep understanding of the medium of opera and that, in parodying opera, the Marx Brothers are in fact parodying the medium of cinema. For instance, take the scene where Harpo changes the scenery and climbs up the operatic setting while the famous tenor aria from $I l$ Trovatore, 'Di quella pira', is sung. Harpo's chaotic act points to the absurdity of unbroken song - the absurdity of a medium catering to song as opera does - and to the significance of the specificity of the operatic plot for the extravagant and passionate singing voice. Yet Harpo's chaotic rendering of opera also points to the way cinema simulates operatic absurdity. His gravity-defying climb, rather than using film's 'realistic' illusions, shows the Marx Brothers on the verge of shattering the world in the way that opera (ridiculously?) attempts to transcend it. Here Harpo demonstrates how cinematic possibilities blend with operatic absurdity. ${ }^{310}$

By enacting on the screen what may be performed on the stage, the Marx brothers are pointing towards the limitations of both genres. Opera, in essence, is allowed to be a little bit absurd. Audiences are happy for divas to sing exquisitely beautiful

\footnotetext{
${ }^{309}$ Grover-Friedlander, “'There Ain't No Sanity Claus!”: The Marx Brothers at the Opera', p. 27.

310 Ibid., p. 27.
} 
phrases and then throw themselves off parapets to their deaths; they can sing a duet with their murderous husband while slowly dying from strangulation; the battlements of Valhalla can crumble while everyone runs around and sings. These scenes are not realistic, opera in and of itself never is. Cinema, on the other hand is a medium associated with realistic performance, yet interestingly, when it is combined with the absurdities of opera cinema is exposed as equally absurd. An analysis of Lepage's La Damnation de Faust reveals many pertinent issues of reality, technology and the many locations of meaning in this work. Yet it seems that Lepage, as Glass and the Marx brothers before him, is exposing the illusions of cinema rather than employing its technologies to create a realistic Faust.

\section{LIGHTS, CAMERA, ACTION!}

In the opening scene we are presented with an aged scholar, Faust, who is perched upon a tall ladder leaning against a large projected screen of books... From this very moment, it is clear that the screen construction Lepage has created enables him to tell parts of this story in a very visual and cinematic manner that may not usually be accessible with more traditional staging technologies. The very fact that the books are not real but simply a two-dimensional projection is a reiteration of Faust's own feelings towards his life and life's work. The projected library becomes a metaphor - his search for knowledge has been an illusion, his life has lacked any real experiences and his books have yielded nothing of any real meaning, only an experience of life gained living vicariously through others. Faust has lived a two-dimensional life just as his books are twodimensional. The possibilities a screen allows enables Lepage to 
take the audience inside Faust's own mind and perhaps to see the world as Faust sees it. The books are soon replaced by a flock of black birds flitting across a white screen. In Faust's mind the audience can see how even nature has lost its colour. Everything in Faust's mind has become the black and white colour of the books themselves. The chorus when they first enter are also dressed only in black.

When colour does burst onto the stage it is treated in a very interesting way. Faust, in part one, is commenting on village life. And whilst the chorus are standing grouped together and singing facing straight toward the audience, dancers on the scaffold behind them are acting out the actual scenes they are describing. This separation between voice and body is worth considering as it comments again on the nature of cinema and the screen itself. The black-clad chorus become the black speakers of the cinema while the colourful mute dancers represent the picture on the screen. During the Rákóczy March, a scene of typical village experience is outlined. The boys are going off to war and the women must say goodbye. Soldiers, dressed in military attire, enter the lower level of the scaffold marching backwards. Women, dressed as peasants enter the upper level of the scaffold walking backwards, clutching handkerchiefs and waving. The act of soldiers and women walking backwards in a very stylized manner can be read as a reference to the way in which the nature of film technology works. The horizontal nature of the movement, with the dancers moving backwards across the stage effectively creates a sense that the audience is watching the scene in rewind. This in turn can be seen as a reinforcement of the meaning of this scene. War is a regress back to oblivion, and as soldiers march 
on into battle they march away from life itself. The use of the soldiers marching backwards not only alludes to film practices but also reinforces the opposition between the real and unreal elements of cinema and the stage. The act of walking backwards is an artificial and unnatural act yet something that is idiomatic to the screen. The metaphor of the screen is used to reflect meanings within Berlioz's work.

After the Rákóczy March, the scaffold is subdivided into a series of identical studies. In each study there is a scholar in silhouette working at his desk and occasionally getting up to find a book from his bookcase. Faust himself is in one of these compartments. The overall effect is that the audience is witnessing a multiplicity of Fausts. This can be read as yet another reference to the inherent nature of film technology. Images in film are able to be copied exactly and reproduced ad infinitum. Within the realm of the theatre nothing can be replicated exactly. Herein lies one of the joys of theatre - it is manifestly impossible to have the exact same visual experience twice. The effect of multiplicity in the theatre in itself may not mean much but within the context of a theatrical world exploring the limits of cinema and the meeting points between these two forms, multiplicity takes on new meanings. To have a whole set of identical settings, with individual actors playing out each scene, is like watching multiple television screens live. Again this is problematic. Joe, paraphrasing the ideas of the cultural theorist Jean Baudrillard, stipulates that: 'postmodernist theory lies foremost in terms of this eclipse, as a proliferation of simulacra. In post-modern culture, in which technologically reproduced images dominate, the hard-and-fast distinction between the real and its representation or simulation is effaced. 
"Models" take the place of the real and become "hyper-real", more real than real. ${ }^{311}$ Yet the multiple physical bodies on stage question this hyper-reality. As the notion of multiplicity is made conspicuous we are being asked to question the apparent reality of the screen. The imposition of real and individual bodies within an illusion of multiple screens forces the audience to question what is more realistic - the screen or the stage? This exploration of the appearance and illusion of reality is central to the Faust legend. Faust is able to seduce Marguerite because he appears to be a good man. Marguerite appears to fall in love with Faust yet is under an enchantment and also capable of murdering her mother and baby. This multiplicity of Fausts also reinforces the monotony of Faust's life - in this production it is suggested that he is not an individual but one of many; his own life is of no consequence and not any more significant than any other.

Faust, tired of his life, decides to end it all. Yet before the vial of poison reaches his aged lips Lepage, again, whisks the audience off to another place of visual sumptuousness. As the Easter hymn interrupts his suicidal brooding, Faust's fellow scholars leave the scaffold and the scene goes dark. Faust reappears on the stage itself as the grid-like studies are replaced with an immense projection of a stained glass window. Only particular cross-sections of the scaffold are lit to create five crosses and as the scene progresses a Jesus figure swings out and assumes the position of Christ being crucified. Again we have a mix between a real person playing Jesus and a projected image of the church that contains him. The sense of multiples

311 Joe, 'The Cinematic Body in the Operatic Theatre: Philip Glass's La Belle et la Bête', p. 68. 
from the previous scene is continued with four more Jesus figures appearing throughout the scene. This scene also illustrates how cinematic technologies, like the theatre of the imagination Berlioz created, can jump from one scene to another without having to explain itself or pause to roll on new scenery. Faust can be immediately transported from study to church without a pause, a curtain drop or visual break.

Of course, where ever there is a church there must be a devil lurking near by. In many ways Lepage has used some very traditional theatrical devices in his treatment of Mephistopheles. His costume is purely for theatrical effect and would look somewhat silly on the contemporary silver screen. He wears the traditional devilish colour of red, and is dressed in leather pants, leather jacket, pointy shoes, and a cap with two long feathers foppishly situated where horns might have appeared. His costume has various ribbing, fur and scales to make him look all the more like a creature come from the depths of hell. Again when he convinces Faust to travel with him this is both a moment of theatricality and yet at the same time is not. Berlioz has not lingered on this salient moment in Faust's fall from grace. The devil barely appears before Faust is agreeing to see what he has to offer. So too, Lepage does not use this moment to employ any special cinematic effects to transform the old Faust into a younger man. Instead the tenor is simply sent off stage and soon reappears dressed in finer attire and looking younger without his long, obviously fake, white beard.

The scene in Auerbach's cellar is also an interesting use of the stage. For this scene Lepage has again reverted back to using the 
stage in a fairly traditional manner. This is a hellish scene that is devoid of the technologies that Lepage has used elsewhere and the director seems to have gone into the fictive world of opera proper. This is also a scene that does not seem to reflect on the reality and superficiality apparent and important to other scenes. This infernal cellar is placed at the bottom of the scaffold on stage level. The set is now comprised of many tables in a row lit with garish red light. Various tankards and beer glasses fill the tables and much revelry takes place. This is a highly detailed scene that is, ironically, much more effective in the movie version of the opera. ${ }^{312}$ This scene is coloured with large amounts of very amusing details. In the film version, we see Brander, having finished his song, go on to mimic a priest. Using a dead rat as an aspergillum, he dips it into a pitcher of wine and proceeds to bless his fellow drinkers, flicking the winedrenched rigor mortis rat about. Unfortunately, speaking from personal experience, this very amusing moment is lost when watching from the stalls in the Metropolitan Opera House. It seems ironic that a scene that in many ways is treated in a very traditional theatrical way is less effective on the stage than on the screen. This could be blamed partially by the size of the stage used. As the full stage is taken up with the massive scaffold structure, and it is only the floor and first level of the scaffold that is being used in this scene, most of the stage is oppressively dark and creates the illusion of making the actors on stage seem smaller than they really are. This scene could also be read as a parody of the operatic conventions that Lepage is trying to move away from. The fact that this scene is much

312 Like many productions at the Metropolitan Opera, Lepage's La damnation was broadcast live in cinemas, and these recordings were also broadcast internationally as well as made available on the internet. 
more effective with the help of the cinematic close up is telling. Was this an intentional decision made by the director?

While the majority of the revellers are in the cellar itself, Faust and Mephistopheles observe the scene from the first level of the scaffold - this connection to the scaffold construction is important. When Mephistopheles wishes to sing the revellers his own song he must climb off the scaffold and onto the stage itself. Brander, too, must climb out of his cellar and on to the stage to sing his song. For these phenomenal songs it seems that they belong entirely to the realm of the operatic stage and perhaps cannot be contained within the scaffold/screen construction. This constant climbing on and off the scaffold reinforces the separation between the scaffold/screen and the stage itself.

Mephistopheles, perhaps realising his Faust will not be distracted with mere alcohol and easy bodily pleasures, resorts to a much more metaphysical temptation - the love of a beautiful, virtuous and virginal young woman. Mephistopheles lulls Faust to sleep and fills his dreams with visions of Marguerite. The music is luxurious and Lepage's treatment fills every bar with extraordinary visual sumptuousness. In this scene the scaffolding once again turns into a giant screen. The lower two-thirds project a night sky reflected in rippling water. Faust and Mephistopheles are in an actual physical boat that is being rowed across the top of this projected body of water. The ripples seemingly move in reaction to the movement of real oars. Mephistopheles steps out of the boat, which then capsizes, 
throwing Faust into a body of virtual water. ${ }^{313}$ While Mephistopheles and the sylphs lull Faust with dream inducing music, we see filmed images of Faust swimming in this body of water while Marguerite-like nymphs appear and swim around him. The first image of the character Marguerite occurs in this scene. The projected face of Susan Graham is shown and seemingly from underwater we hear Faust sing her name, 'Marguerite', over and over again. This scene again contains many interesting problems. The audience is presented with Lepage's own unique mixing of projected cinematic image and the realities of a live stage. It is in this scene that the very mechanics of the staging can be literally heard and seen by the audience itself. When the boat tips Faust overboard there is a discernable harsh sound that can be heard as the side of the wooden boat hits the scaffold. This 'thunk' may well just be part of the bargain that an audience must be willing to make when entering the theatre. We are supposed to be willing enough to suspend our disbelief for the evening and these small details may well be kindly overlooked. There is also a possibility that perhaps this was more of an artistic choice made by the director. Considering the extremely technical nature of the entire show it is hard to imagine that the creative team could not have done something to diminish this un-operatic sound. Yet the essence of Mephistopheles's character is his ability to create illusion and fiction. The sound of the boat capsizing highlights the artificiality of the projected images the audiences subsequently sees. We are reminded of the theatricality of Mephistopheles. The very image of Marguerite on the screen must be understood as artificial, though the screen lends her image a sense of reality. Lepage has embraced the role of

313 At this point Mephistopheles is effectively walking on water... 
Mephistopheles as a type of evil creator, using illusion to seduce Faust. Yet Lepage has decided to consciously use technology as the locus of this power. Mephistopheles is powerful because he seems to be in control of the multitudes of technologies that surrounds him. These technologies are made present to the audience through these small 'thunks'. While this positions Mephistopheles as the most dominant person on stage, his association and reliance on technology itself perhaps also diminishes his power. The audience witnesses that indeed the only power this devil has is conjured through the very real and human one of technology.

The next scene is one of the most visually exciting scenes of this entire production. Faust, infused with a sense of urgency and purpose declares that he must have Marguerite and consequently the devil speeds them off to her village. Again we are confronted with the narrative of boys going off to war. This time instead of walking backwards, the soldiers defy gravity as well as nature, and walk up the front face of the scaffold itself. The front face is still operating as a screen and projecting a large expanse of grass that moves and is trampled as the soldiers march through it. As they reach the top they fall down to women waiting underneath. ${ }^{314}$ The women catch their bodies and grieve over them before their soldiers, too soon, resume their dangerous march to the top. Lepage seems to have juxtaposed two of his most visually spectacular scenes next to each other. The scene with Faust submerged in the water

314 This production utilised new technologies developed by Holger Förterer. The projections seen on the screen actually respond to the live movements of the singers, dancers and acrobats on stage, primarily through monitoring and responding to the body temperature of the performers and the vibrations of the singers' voices. 
highlights the extent and capabilities of the cinematic screen the sumptuousness of the water, the enlarged projected image of Marguerite as if we are voyering into Faust's own subconscious. These are images of Faust's fantasy projected for the audience to see and comprehend. If in this previous scene the screen was used to project fantasy, in this scene it is used to lend a degree of realism to the obviously unnatural act that the audience is seeing. The projection of the grass responds to the weight and motion of the soldiers, and acts as if it were real grass. Yet, in this scene, which depicts a 'real' event in the story, we are confronted with the very unnatural and surreal act of soldiers walking up a screen. The reality of the scene is subverted. Why has Lepage decided to do this? This is an event that in some sense is only truly effective in the live theatre. There is a present sense of theatricality - of stage magic relying on the suspension of disbelief. The soldiers move on top of and outside of the two dimensional nature of the screen - this simply couldn't be reproduced on the cinematic screen alone. The sense of subversion collapses within itself when reduced again into the cinematic two-dimensional world. This scene calls into question the very meaning of the stage and the screen. The screen has previously shown the audience fantasy that is obviously unreal, the screen has now also acted as a surface that is then walked upon by live performers. Whereas the fantasy is shown in some aspects in a very natural and realistic way, real acts are shown in a symbolic, fantastical manner. This subversion of both forms creates a sense of unease and conscious creation. To some degree the 'magic' of these scenes are laid bare. The technology points towards the way in which Mephistopheles is a supreme creator of 'effects'; it seems that both the director and singer performs this devilish role in this production. 
Having questioned the nature of the screen and stage in the two previous scenes, the two come together in a fairly traditional manner to portray Marguerite's home. The scaffold becomes a grand house, the façade dominated by large wide windows. These windows are 'real' and can open to show Marguerite inside singing the uncanny and memorable 'Le roi de Thulé'. As she sings Mephistopheles and Faust watch from the floor of the stage - this creates a sense that they are watching a screen and Marguerite is the dazzling movie star. As always when Mephistopheles is present, this screen must be subverted and invaded by creatures from the stage. He sends his demonic ballerinas, dressed in white, to dance within Marguerites own house. The ballet gives the audience a taste of what is to come. The dancers are soon joined by ghoulish creatures who jump and fly on and off the scaffold, at times seemingly flying well into the space of the audience. Cautionary tale over, Marguerite suddenly comes face to face with the man she has seen in her dreams. The lovers have little time to embrace before the grandmaster Mephistopheles interrupts them. All this singing and dancing has woken the neighbours who are certain that there is someone in the house with Marguerite. As the villagers stream along the corridors of her home Faust and Mephistopheles escape by ladder to the safety of the trapdoor below.

In the following act we are returned to Marguerite's house, though it soon becomes obvious that a lot of time has passed. The colours she wears have changed from a pure white to the colour of all fallen women - a deep red. Her aria is delivered 
from the stage itself and as she sings, her enlarged singing image is projected behind her. Yet her projected image seems prerecorded and thus doesn't match with the exact timing of the aria being sung live. Effectively she is also both singing and mute at exactly the same time. The real Marguerite is singing to her audience; her projected image is only giving the illusion of sound. This dichotomy highlights the multiplicity and illusion between the screen in which her image is manipulated and projected as if by Mephistopheles himself, and her real resonating body - the real Marguerite removed from the screen/scaffold briefly casting aside the puppet strings of her devilish manipulator. We are being presented with a 'real' Marguerite and a 'false' Marguerite and we can understand from Marguerite's duality that Faust has never gained access to the 'real' Marguerite or to 'real' love or affection he craved but simply the illusion of it. His torment is the psychological angst of wanting 'real' experiences in an 'unreal' world. That the reality of this scene, and in fact the entire Lepage production, is located on the stage whereas illusion and falsity is located within the screen is in opposition to the normal understanding of these two media.

The duplicity of the soprano's body perhaps reflects her new position. The projected image coming from the stage is in fact mute and only a construction, a two-dimensional illusion. It is this version of Marguerite, this fantasy of a perfect woman, that Faust first saw and fell in love with. The fact that this image of Marguerite is juxtaposed against the 'live' Marguerite only heightens the sense that the screen version is fraudulent and reiterates the themes of Goethe's play. Faust does not fall in love with the real Marguerite but a construction of her created 
for him by Mephistopheles. In this scene we also see how Lepage is using technology itself to narrate aspects of this work that Berlioz chose not to set. Once her aria is finished we again hear the military trumpets call. Marguerite reminds us that these are the same trumpets that once heralded Faust into her life.

This time, Faust does not appear - the soldiers are on their way to arrest Marguerite. Flames engulf the entire screen, before it turns black and begins to be filled with a grid like pattern. It is obvious that the grid represents Marguerite's prison. Within the score, the only suggestion of the soldiers comes from their trumpet theme, the audience doesn't know that they are on their way to arrest her. The audience knows that Marguerite has been imprisoned only when Mephistopheles alludes to this in the next scene. Lepage has managed to use the screen to fill in this part of the story visually.

Through Marguerite's aria we learn that Faust has abandoned her. While she has turned to matricide, Faust has retreated to the countryside to reflect on nature. To all intents and purposes it seems as if he has simply lost interest in his latest conquest. At this point Mephistopheles returns to the stage and again Lepage uses an interesting mix of live and projected images to suggest certain themes contained within this story. Faust sings his invocation under three stylised projected images of trees. As Mephistopheles walks across the scaffold to inform Faust of Marguerite's predicament the trees wither. While again this is a rather obvious symbol of Mephistopheles's destructive powers Lepage has employed both live and projected images to show this. While the trees themselves are projections the leaves that fall from them are real. Mephistopheles operates in both the world of imagination and the 'real' world of the story. His 
destructive powers are expressed using the imaginative world of the screen and the physical actuality of real leaves falling. The mixture of the two forms of media in this scene could also highlight a larger theme of this work and the spirit of romanticism in general. In Berlioz's La Damnation de Faust even Marguerite does not manage to maintain Faust's attention. Her love does not seem to provide the solace that he was looking for in the opening scenes of this work. Instead he retreats into the wonder and power of nature itself. Mephistopheles recognises his diminished powers when compared to the majesty of nature and thus reminds Faust of his past discretions and the consequences that have befallen Marguerite. It is Faust's sense of guilt that provides the motivation to sign away his soul rather than any promise that the devil can make him. The constant juxtaposition between the realities and illusions of the screen and stage could mirror the growing conflict between the temptations and restrictions of religion and the growing religiosity of science as exemplified within the philosophies of organicism. ${ }^{315}$ An understanding of what it was to be a nineteenth-century intellectual is essential in understanding Berlioz's own creation of Faust and how Lepage's production reflects these ideas. As Jacques Barzun reminds us, Berlioz was brought up in the Holy Apostolic Roman Catholic Church. His mother was a firm catholic, his father was a doctor and a man with a keen interest in science. As a result Berlioz was 'reared in both creeds [and] reached manhood imbued with their opposite truths $[\ldots]$ the disparate conceptions of the universe, while doubling the range of his intuitions, must sooner or later

315 Goethe's theories on organicism, for example, included the concept of Urtypen - or 'prototypical' forms. The Urpflanz for instance was believed to be a plant that generated all the seeds for every known botanical species. See David L. Montgomery, 'The Myth of Organicism: from Bad Science to Great Art' The Musical Quarterly 76/1 (1992), p. 18. 
confront him with an unresolved intellectual conflict. ${ }^{316}$

Berlioz's Faust also struggles between the adoration of nature and his wonder of the biological world and his devotion to Christianity. This is both a religious fight for his soul and a conflict between Faust's love of nature and the trickery of Mephistopheles.

Mephistopheles provides the horses for Faust's vain attempt to save Marguerite. While the devil has been shown to be a master of both the stage and the screen, offering at times brief glimpses into the mechanics of the magic itself, it seems in this scene that the fundamental structure of this metaphor is coming apart. Instead of one horse each for the two men, the audience is shown six horses. Faust is on the third level of the scaffold while Mephistopheles is on the third. Projected on each level are three horses galloping in sequence. While the horses run, three men in the silhouette shape of Faust and Mephistopheles, are suspended and held in place to look as if they are riding these projected horses. All the while Faust and Mephistopheles stand to the side watching and singing. The row of horses in sequence separated by the framework of the scaffold gives the effect that the audience is in fact watching a slowed down film reel. The reel has slowed to the point that the individual frames of the film have become apparent. This is further enforced by the fact the characters of Faust and Mephistopheles are not involved in this action but standing removed from the overall 'screen'. This exposure of the film, the exposure of the magic behind the moving picture reiterates the final exposure of Mephistopheles as a devil-manipulator. His power throughout this production

\footnotetext{
316 Jacques Barzun, 'Berlioz as man and thinker', p. 11.
} 
has been reinforced by his manipulation of visual media, constantly blurring the lines between reality and illusion. It is the obvious conclusion of this over-arching metaphor that his revelation should be shown through an allusion to the core materials of film and cinema itself.

As Faust and Mephistopheles bowl through a group of praying peasants, the lost souls from hell, standing at the bottom of the stage, sing their Berliozian devilish language, lit in a garish red. It is obvious that Faust has lost his fight with the devil. Though Faust is condemned to the fiery pits of hell, Marguerite is saved. Berlioz insists that her only crime was to love. If the preceding scene is lit with blacks and reds, Marguerite's apotheosis is infused with the blue and white of heaven. The scaffold is abandoned as angel figures fill the stage. A tall ladder is placed at the centre of the stage and in the final bars Marguerite climbs towards the heavens as the curtain falls. Thus the show both starts and ends with a ladder. We have seen how at various moments the ladder has been used throughout this production to climb off and onto the scaffold. Whereas Mephistopheles is happy to climb on and off the scaffold without the any aid, in salient moments both Faust and Marguerite use a ladder. Mephistopheles's athleticism throughout this production illustrates his power over both the screen and the stage and this reiterates his control over all aspects of the production. In contrast Faust and Marguerite are not in control of their environments. That they are so reliant on the practical, even mundane, wooden ladder reflects their very human limitations. 


\section{Conclusion}

As the house lights brighten and the applause dies down, the experience of watching Berlioz's score made spectacle reveals something about all three of the works considered in this study. As we can see, the treatment of visuality in Berlioz's Lélio, Roméo et Juliette and La damnation de Faust within modern contexts can become a vehicle to explore our own modern world where visual mediums are dominant. Lepage explores the relationship between cinema and theatre as is pertinent to our own time just as Berlioz explored the relationships between symphony and opera as was pertinent to his time. As Cairns stated earlier, the cinematic screen can realise the various evocative images and events in Berlioz's music, but we should also be aware that the technology of the silver screen adds its own layers of signification and meaning. Ultimately Lepage's production of $\mathrm{La}$ damnation de Faust from 2008, like Raoul Gunsbourg's production from 1893, foregrounds technology perhaps to the detriment of Berlioz's score. Whereas Gunsbourg's production uses technology in an attempt to mask the non-operatic aspects of Berlioz's score, Lepage employs technology to explore themes within the work itself. The dichotomy between the realism and fantasy presented by the screen, and an exploration of how the theatre itself can subvert the inherent meanings of the cinematic screen adds new layers of significance to Berlioz's score. However, it is possible that the act of physically visualising Berlioz's music perhaps makes these technological issues 'louder' than the music itself. The Lepage production becomes an exploration of the meeting points between reality and illusion, screen and stage, good and evil, but in doing so seems to diminish the impact of Berlioz's music. Analysing both Gunsbourg's and Lepage's productions exposes the way in 
which technology is employed to capture the fantastical images that are contained and highlighted in Berlioz's score. Yet the nature of Berlioz's visuality contained within all of his dramatic concert works is allusive and perhaps resists visual performance. While ideas and meanings can be superimposed upon the work, is the work perhaps so complex in itself that its own embedded narrative disappears in the process?

Within Lélio we can see the first construction of the theatre of the imagination. Through approaching dramatic music from a literary perspective, Berlioz wanted to create the same practice of visual imagining when one listens to narrative music as when one reads a good book. Berlioz then extended this ideal approach to experiencing music in an actively imaginative manner when giving voice to his orchestra and trusting in music's capabilities to re-create a memory of a theatrical performance in Roméo et Juliette. In La damnation de Faust Berlioz created a score filled with specific visual pictures and events written into the structure and timbre of the music itself. While his libretto entreats us to look, it is perhaps an entreaty to look inwards to the theatres within ourselves. The mind is a powerful thing, able to conjure up images and events beyond human capabilities. Like Faust searching for something beyond the limited experiences of his own life, Berlioz, through creating a hybrid work, was looking for something beyond the political world of the opera that he had already experienced.

As Boulez once said:

What Berlioz brought to music was so singular that it has not yet been truly absorbed, has not become an 
integral part of the tradition... He stands at a point where customary judgement cannot easily be applied. I think we must see the principal reason for this in the fact that a large part of his oeuvre has remained in the realm of the imaginary. ${ }^{317}$

This comment was made in 1969. I would hope that Berlioz has indeed been welcomed into 'the tradition' of western art music since then. Indeed impressive performances of many of his works, motivated by the composer's centenary and bi-centenary, have grown the audiences for this wonderful Frenchman. In recovering the visual dimensions hidden within the music, text, form and structures of Lélio, Roméo et Juliette and La damnation de Faust, I hope not to demonise either symphonic, operatic, indeed even cinematic approaches to the performances of these works. Music in itself, like all art forms, cannot contain specific concrete sets of meanings and values. Instead by reminding one of the imaginary theatre that Berlioz created, I hope to have recaptured at least some of the nuanced visual details his music portrays, and to have suggested the implications that the application of these visual details may have for the drama of these vivid and passionate compositions. Boulez contemplated that 'an appropriate style of presentation' had not been found in the performance of Berlioz's music. Ultimately this style of presentation can only be found in our willingness to re-create the theatre for ourselves.

317 Boulez, 'Berlioz and the Realm of the Imaginary' p. 175 


\section{Bibliography}

Abbate, Carolyn. Unsung Voices: Opera and Musical Narrative in the Nineteenth Century. Princeton, NJ.: Princeton University Press, 1991.

-. 'Music: Drastic or Gnostic?'. Critical Inquiry, $30 / 3$ (Spring, 2004), pp. 505-536.

Adorno, Theodor W., In Search of Wagner, trans Rodney

Livingstone, Great Britain: Redwood Burn Ltd, 1981.

Albright, Daniel. Berlioz's Semi-Operas: Roméo et Juliette and La damnation de Faust. Suffolk: University of Rochester Press, 2001.

-. 'Berlioz's Roméo et Juliette: Symphonic Metamorphoses on a 'Theme by Shakespeare.' Journal of Musicological Research, 19/2 (2000), pp. 135-176.

Anonymous. 'Untitled Review’ Le monde artiste, vol. V. 1 February 1903.

Anonymous. 'The "Damnation de Faust", The Times, 11 May 1903.

Baker, Evan. 'Richard Wagner and His Search for the Ideal Theatrical Place.' In Opera in context: Essays on historical staging from the late Renaissance to the time of Puccini, edited by Mark A. Radice. Portland: Amadeus, 1998, pp. 209-240.

Barbier, Patrick. Opera in Paris, 1800-1850: A Lively History, translated by Robert Luoma. Portland: Amadeus Press, 1987.

Barzun, Jacques. 'Berlioz as man and thinker.' In The Cambridge Companion to Berlioz, edited by Peter Bloom. Cambridge: Cambridge University Press, 2000. pp. 11-19. 
-. 'The Meaning of meaning in Music: Berlioz Once More.' In The Musical Quarterly. 66/1 (1980), pp. 1-20.

Berlioz, Hector. The Art of Music and Other Essays (A travers chants). Translated by Elizabeth Csicsery-Rónay. Bloomington, Indianapolis: Indiana University Press, 1994.

- Correspondance Générale de Hector Berlioz. 6 vols. Gen. ed. Pierre Citron. Vol. I: 1803-1832, ed Pierre Citron. Vol. II: 1832-42, ed. Frédéric Robert. Vol. III: 1842-50, ed. Citron. Vol. IV: 1851-5, ed. Citron, Yves Gérard, High Macdonald. Vol. V: 1855-9, ed. Macdonald, François Lesure. Vol. VI: 1859-63, ed. Macdonald, Lesure. Paris: Flammarion, 1972-2003.

-. A Critical Study of Beethoven's Nine Symphonies with a Few Words on his Trios and Sonatas, A Criticism of "Fidelio", and an Introductory Essay on Music. Translated by Edwin Evans. London: W. Reeves, 1958.

- La Critique musicale d'Hector Berlioz: Gen. ed. Yves Gérard. Paris: Buchet/Chastel, 1996-.

-. Evenings with the Orchestra. Edited and translated by Jacques Barzun. Chicago: Chicago University Press, 1999.

- The Memoirs of Hector Berlioz. Translated by David Cairns. New York: Alfred A. Knopf, 2002.

-. Mozart, Weber and Wagner. Translated by Edwin Evans. London: William Reeves, 1969.

-. Les musicians et la musique. Paris: Calmann-Lévy, 1969. 
- Berlioz's Orchestration treatise: A Translation and Commentary. Edited and translated by Hugh Macdonald. Cambridge: Cambridge University Press, 2002.

-. $\quad$ Selected Letters of Hector Berlioz. Edited by Hugh Macdonald. Translated by Roger Nichols. New York, London: W.W Norton \& Company, 1995.

- Hector Berlioz: New Edition of the Complete Works. 26 vols. Gen. ed. Hugh Macdonald. Kassel, etc.: Bärenreiter, 1969-2005.

- Lélio ou Le retour à la vie, Hector Berlioz. New Edition of the Complete Works, Vol. 7. Edited by Peter Bloom. Basel, London, New York, Prague: Bärenreiter, 1992.

- Roméo et Juliette, Hector Berlioz. New Edition of the Complete Works, Vol. 18. Edited by D. Kern Holoman. Kassel, Basel, London, New York: Bärenreiter, 1990.

-. La damnation de Faust (Supplement), Hector Berlioz. New Edition of the Complete Works, Vol. 8b. Edited by Julian Rushton. Kasel, Basel, Tours, London: Bärenreiter, 1979.

- La damnation de Faust, Hector Berlioz New Edition of the Complete Works, Vol.8a. Edited by Julian Rushton. Kassel, Basel, Tours, London: Bärenreiter, 1979.

Bloom, Peter. 'A return to Berlioz's "Retour à la vie"'. The Musical Quarterly, 64/3 1978, pp 354-385.

-, ed. Berlioz: Scenes from the Life and Work. New York: University of Rochester Press, 2008. 
- $\quad$ ed. Berlioz: Past, Present and Future. New York: University of Rochester Press, 2003.

- $\quad$ ed. The Cambridge Companion to Berlioz. Cambridge: Cambridge University Press, 2000.

—, ed. Berlioz. Studies. Cambridge: Cambridge University Press, 2000.

Bomberger, E. Douglas. 'The Neues Schauspielhaus in Berlin and the Premiere of Carl Maria von Weber's Der Freischütz.' In Opera in context: Essays on historical staging from the late Renaissance to the time of Puccini. Edited by Mark A. Radice. Portland: Amadeus, 1998, pp. 147-169.

Borchmeyer, Dieter. Richard Wagner: Theory and Theatre. Translation by Steward Spencer. Oxford: Clarendon Press, 1991.

Boulez, Pierre. 'Berlioz and the Realm of the Imaginary.' Daedalus, 115/4 (1986), pp. 175-184.

Braam, Gunther; Döhring, Sieghart; Jacobshagen, Arnold eds. Berlioz, Wagner und die Deutschen. Köln: Verlag Dohr, 2003.

Brittan, Francesca. 'Berlioz and the Pathological Fantastic : Melancholy, Monomania, and Romantic Autobiography.' In Nineteenth-Century Music. 29/3 (2006), pp. 211-239.

Brussel, Robert. 'Académie nationale de musique: La damnation de Faust, légende dramatique d'Hector Berlioz, adaptée à la scène par M. Raoul Gunsbourg.' Le Figaro, 11 June 1910, p. 5.

Cairns, David. Berlioz: The Making of an Artist 1803-1832. London: André Deutsch Limited, 1989. 
- Berlioz: Servitude and Greatness: 1832-1869. London: Allen Lane, The Penguin Press, 1999.

- 'Berlioz and Criticism: Some Surviving Dodos.' The Musical Times, 104/1446 1963, pp. 548-551.

Charlton, David, ed. The Cambridge Companion to Grand Opera. Cambridge: Cambridge University Press, 2003.

Chua, Daniel K. L. Absolute Music and the Construction of Meaning. Cambridge: Cambridge University Press, 1999.

Clément, Catherine. Opera or The Undoing of Women. Translation Betsy Wing. Minneapolis: University of Minnesota Press, 1988.

Condé, Gérard. 'Commentaire musical et littéraire.' L'avant-scène opera : Hector Berlioz La damnation de Faust, Vol. 22. Edited by Gérard Condé. Paris: Éditions Premières Loges, 1995, pp 10-59.

- - ed. L'avant-scène opera : Hector Berlioz La damnation de Faust, Vol. 22. Paris: Éditions Premières Loges, 1995.

Cohen, H. Robert. The original staging manuscripts for twelve Parisian operatic premieres. Stuyvesant, NY: Pendragon, 1991.

Dahlhaus, Carl. Nineteenth-Century Music. Translated by J. Bradford Robinson. Berkeley: University of California Press, c.1989.

Elliot, Jr., John R. 'The Shakespeare Berlioz Saw.' Music \& Letters, 57/3 (1976), pp. 292-308. 
Ellis, Katharine. Music criticism in nineteenth-century France: La revue et gazette musicale de Paris, 1834-80. Cambridge: Cambridge University Press, 2007.

von Goethe, Johann Wolfgang. Faust, Part One. Translated by David Luke. Oxford: Oxford University Press, 1987.

- Faust, Part Two. Translated by David Luke. Oxford: Oxford University Press, 1994.

Grey, Thomas S. 'Hanslick, Eduard.' In Grove Music Online. Oxford Music Online.

http://www.oxfordmusiconline.com/subscriber/article/grove/music/12 341 (accessed August 16, 2009).

- 'Richard Wagner and the legacy of French grand opera.' In The Cambridge Companion to Grand Opera. Edited by David Charlton. Cambridge: Cambridge University Press, 2003, pp. 321-343.

Grover-Friedlander, Michal. Vocal Apparitions: The Attraction of Cinema to Opera. Princeton, N.J.: Princeton University Press, 2005.

- “ “There Ain't No Sanity Clause!”: The Marx Brothers at the Opera.' In Between Opera and Cinema. Edited by Jeongwon Joe and Rose Theresa. New York: Routledge, 2002, pp. 19-37.

Gunsbourg, Raoul. Berlioz: La damnation de Faust, Mise-en-scène. Paris: Costallat \& Co., c.1907.

Haar, James. 'The operas and the dramatic legend.' In The Cambridge Companion to Berlioz. Edited by Peter Bloom. Cambridge: Cambridge University Press, 2000, pp. 81-95. 
Hoeckner, Berthold. Programming the Absolute: Nineteenth-Century German Music and the Hermeneutics of the Moment. Princeton and Oxford: Princeton University Press, 2002.

Hoffmann, E.T.A. 'Beethoven's Instrumental Music.' In Source Readings in Music History, Vol. V, The Romantic Era. Edited by Oliver Strunk. London: Faber and Faber Ltd, 1981. pp 35-41.

Holoman, D. Kern. Berlioz. Cambridge, Massachusetts: Harvard University Press, 1989.

- Ed. The Nineteenth-Century Symphony. New York: Schirmer Books, 1997.

Hudson, Elizabeth. '... qualche cosa d'incredibile...': Hearing the Invisible in Macbeth', Cambridge Opera Journal Vol. 14 No. 1/2, pp 11 - 29.

Huebner, Steven. French Opera at the Fin de Siècle: Wagnerism, Nationalism, and Style. Oxford: Oxford University Press, 1999.

- $\quad$ "Faust (ii)." In The New Grove Dictionary of Opera. Edited by Stanley Sadie. Grove Music Online. Oxford Music Online, http://www.oxfordmusiconline.com/subscriber/article/grove/ music/O901567 (accessed August 6, 2009).

Hugo, Victor. Cromwell. Paris: Librairie de l'Hachette et Compagnie, 1858.

Joe, Jeongwon. 'The Cinematic Body in the Operatic Theatre: Philip Glass's La belle et la Bête.' In Between Opera and Cinema. Edited by Jeongwon Joe and Rose Theresa. New York: Routledge, 2002, pp. 59-73.

Joe, Jeongwon, and Theresa, Rose, eds. Between Opera and Cinema. New York: Routledge, 2002. 
Johnson, James H. Listening in Paris: a cultural history. Berkeley: University of California Press, 1995.

Kemp, Ian. 'Romeo and Juliet and Roméo et Juliette.' In Berlioz. Studies. Edited by Peter Bloom. Cambridge: Cambridge University Press, 2000.

Langford, Jeffrey. "The "Dramatic Symphonies" of Berlioz as an Outgrowth of the French Operatic Tradition.' The Musical Quarterly, 69/1 (1983), pp. 85-103.

- 'The Symphonies.' In The Cambridge Companion to Berlioz.
Cambridge: Cambridge University Press, 2000, pp. 53-68.

Leppert, Richard D. The Sight of Sound: music, representation, and the history of the body. Berkeley: University of California Press, 1993.

Lippman, Edward Arthur. Review of 'Berlioz: Lélio or The Return to Life, Lyric Monodrama, Op. 14B. André Charpak, narrator; Joachim Kerol, tenor; Gabriel Baquier, baritone; Orchestra and Chorus of the New Paris Symphony Association, cond. René Leibowitz. 12" LP. Vox Pl 8250’. The Musical Quarterly, $40 / 2$ (1954), pp. 276-279.

McClary, Susan. 'Narrative agendas in "Absolute Music: Identity and Difference in Brahm's Third Symphony'. In Ruth Solie (ed.), Musicology and Difference: Gender and Sexuality in Music Scholarship, Berkeley: University of California Press, 1993.

Macdonald, Hugh. The Master Musicians: Berlioz: Series Ed. Stanley Sadie. London, Melbourne, Toronto: J. M. Dent \& Sons Ltd, 1982.

- Review of 'Berlioz: Symphonie fantastique; Lélio. Barrault, Mitchinson, Shirley-Quirk/LSO Chorus/LSO/Boulez.' The Musical Times, 110/1515 (1969), p. 497. 
Macnutt, Richard. 'Berlioz Forgeries.' In Berlioz: Past, Present, Future. Edited by Peter Bloom. Suffolk: University of Rochester Press, 2003, pp 173-192.

Maguire et. al., Simon. 'Capuleti e i Montecchi, I.' In The New Grove Dictionary of Opera, edited by Stanley Sadie. Grove Music Online. Oxford Music Online, http://www.oxfordmusiconline.com/subscriber/article/grove/music/O 004891 (accessed August 9, 2009).

Micznik, Vera. 'The Musico-Dramatic Narrative of Berlioz's Lélio.' In The Musical Voyager: Berlioz in Europe. Edited by David Charlton and Katharine Ellis. Frankfurt am Main: Lang, 2007, pp. 184-207.

- ' Of Ways of Telling: Intertextuality and Historical Evidence in Berlioz's Roméo et Juliette', 19th-Century Music 24/1 (2000), pp. 21-61.

Montgomery, David L. 'The Myth of Organicism: from Bad Science to Great Art', The Musical Quarterly 76/1 (1992), pp. 17-66.

Sanna Pederson, 'Defining the Term 'Absolute Music' Historically’, Music \& Letters, 90/2 (2009) pp. 240 - 262.

Pendle, Karin. and Wilkins, Stephen. 'Paradise Found: The Salle le Peletier and French Grand Opera.' In Opera in Context: Essays on historical staging from the late Renaissance to the time of Puccini. Edited by Mark A. Radice. Portland: Amadeus, 1998, pp. 171-207.

Raby, Peter. 'Shakespeare in Paris.' In The Musical Voyager: Berlioz in Europe. Edited by David Charlton and Katharine Ellis. Frankfurt am Main: Lang, c.2007. pp. 208-233.

Radice, Mark A., ed. Opera in context: Essays on historical staging from the late Renaissance to the time of Puccini. Portland: Amadeus, 1998. 
van Rij, Inge. Brahms's Song Collections. Cambridge: Cambridge University Press, 2006.

Rodgers, Stephen. Form, Program, and Metaphor in the Music of Berlioz: Cambridge: Cambridge University Press, 2009.

Rosen, Charles. The Romantic Generation. Cambridge, Massachusetts; Harvard University Press, 1995.

Rushton, Julian. Berlioz, Roméo et Juliette. Cambridge: Cambridge University Press, 1994.

- The Musical Language of Berlioz: Cambridge: Cambridge University Press, 1983.

-. 'Music and the poetic.' In The Cambridge History of NineteenthCentury Music. Edited by Jim Samson. Cambridge: Cambridge University Press, 2001, pp. 41-52.

- ' 'Genre in Berlioz.' In The Cambridge Companion to Berlioz. Edited by Peter Bloom. Cambridge: Cambridge University Press, 2000.

Samson, Jim. 'The musical work and nineteenth-century history.' In The Cambridge History of Nineteenth-Century Music. Edited by Jim Samson. Cambridge: Cambridge University Press, 2002, pp. 3-28.

- $\quad$ ed. The Cambridge History of nineteenth-Century Music. Cambridge: Cambridge University Press, 2002.

Scott, Michael. 'Raoul Gunsbourg and the Monte Carlo Opera.' The Opera Quarterly, 3/4 (1985-1986), pp. 70-78. 
Scruton, Roger. 'Absolute music.' In Grove Music Online. Oxford Music Online,

http://www.oxfordmusiconline.com/subscriber/article/grove/music/00 069 (accessed July 26, 2009).

- 'Programme music.' In Grove Music Online. Oxford Music Online, http://www.oxfordmusiconline.com.helicon.vuw.ac.nz/subscribe r/article/grove/music/22394 (accessed July 26, 2009).

Shakespeare, William. Romeo and Juliet. Edited by Jill L. Levenson. Oxford: Oxford University Press, 2000.

Simpson, J. A. and Weiner, E. S. C., eds. The Oxford English Dictionary, Vol. IX 'Look - Mouke'. Oxford: Clarendon Press, 1989.

Smart, Mary-Ann. Mimomania: Music and Gesture in Nineteenth-Century Opera. Berkeley: University of California Press, 2004.

Solie, Ruth (ed.). Musicology and Difference: Gender and Sexuality in Music Scholarship, Berkeley: University of California Press, 1993.

Taruskin, Richard. The Oxford History of Western Music: Volume 3 - The Nineteenth Century. New York: Oxford University Press, 2005.

Theresa, Rose. 'From Méphistophélès to Méliès: Spectacle and Narrative in Opera and Early Film.' In Between Opera and Cinema. Edited by Jeongwon Joe and Rose Theresa. New York: Routledge, 2002, pp. 1-18.

Gary Tomlinson. Metaphysical Song: An Essay on Opera. Princeton: University of Princeton Press, 1999.

Ventura, August. 'Dreamcatcher.' In Opera News 73/4 (2008), pp. 20-23.

Whittaker, W. G. 'Berlioz's “Lelio”: A Strasbourg Performance.' The Musical Times, 70/1039 (1929), pp. 814-815. 
Wright, Lesley. 'Berlioz in the Fin-de-siècle Press.' In Berlioz: Past, Present, Future. Edited by Peter Bloom. Suffolk: University of Rochester Press, 2003, pp 158-172.

The Metropolitan Opera Playbill (November 2008). 